\title{
0 lugar da autogestão no Governo Lula
}

Fernanda Accioly Moreira

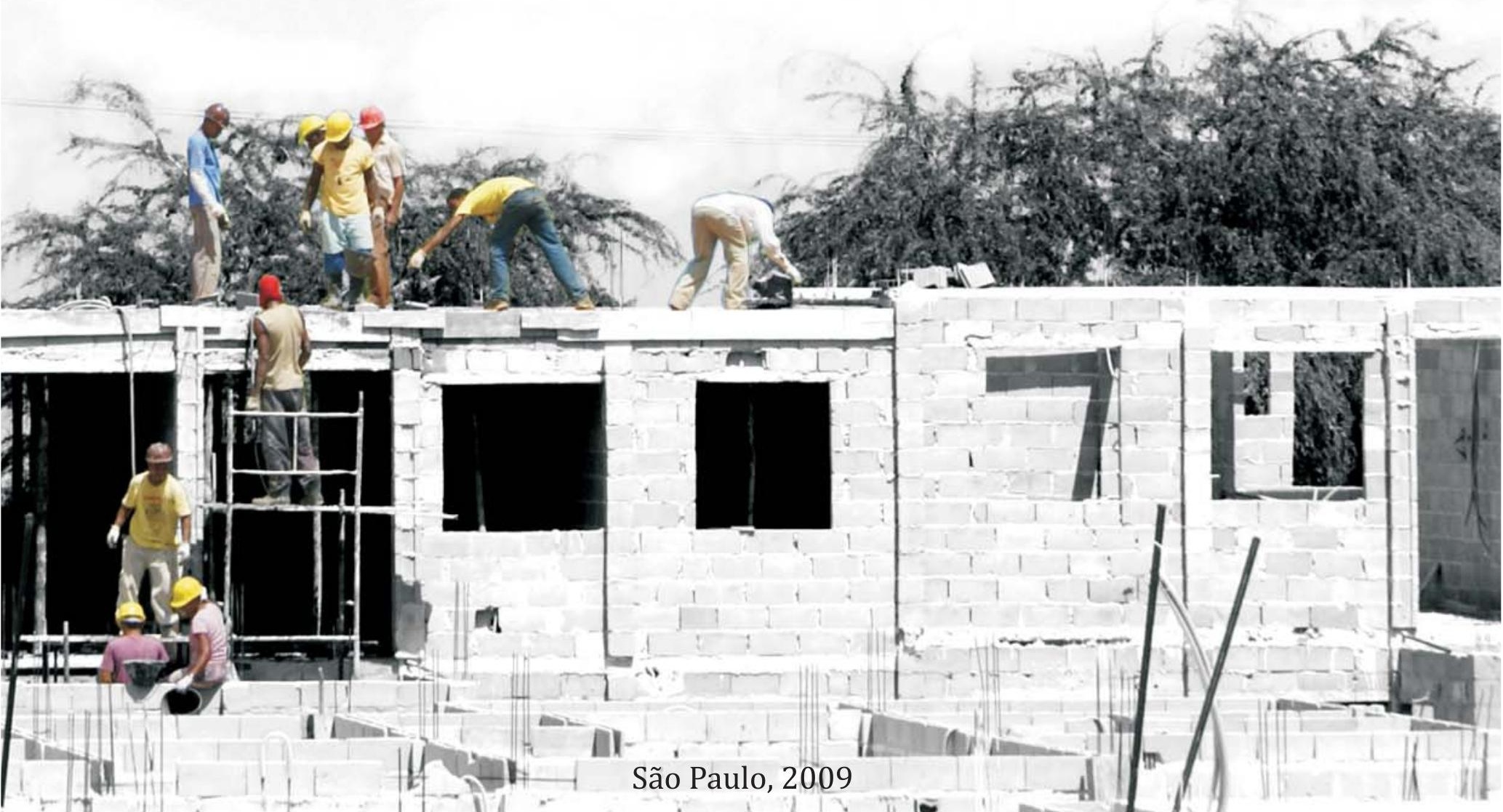




\title{
Fernanda Accioly Moreira
}

\section{O lugar da autogestão no Governo Lula}

\begin{abstract}
Dissertação apresentada à Faculdade de Arquitetura e Urbanismo da Universidade de São Paulo como requisito para obtenção do título de Mestre.
\end{abstract}

Área de Concentração: Habitat

Orientador: Prof. Dr. Reginaldo Nunes Ronconi 
AUTORIZO A REPRODUÇÃO E DIVULGAÇÃO TOTAL OU PARCIAL DESTE TRABALHO, POR QUALQUER MEIO CONVENCIONAL OU ELETRÔNICO, PARA FINS DE ESTUDO E PESQUISA, DESDE QUE CITADA A FONTE.

E-MAIL: fefaccioly@yahoo.com.br

Moreira, Fernanda Accioly

M838L O lugar da autogestão no Governo Lula /

Fernanda Accioly Moreira. --São Paulo, 2009.

195 p. : il.

Dissertação (Mestrado - Área de Concentração: Habitat) - FAUUSP.

Orientador: Reginaldo Nunes Ronconi

1. Habitação 2. Autogestão 3. Movimento popular

4. Governo federal I.Título

CDU 711.58 


\section{O lugar da autogestão no Governo Lula}

Dissertação apresentada à Faculdade de Arquitetura e Urbanismo da Universidade de São Paulo como requisito para obtenção do título de Mestre.

Área de Concentração: Habitat

Orientador: Prof. Dr. Reginaldo Nunes Ronconi

Banca examinadora

Instituição Assinatura

Instituição Assinatura

Instituição Assinatura

Aprovada em: 

"Nós queremos que vocês ajudem a propor, que vocês exijam, que vocês nos empurrem (...) Não se importem com as nossas caras feias. Cobrem o que é direito de vocês.".

Presidente Luiz Inácio Lula da Silva, Abertura da 1a Conferência Nacional das Cidades, 23 de outubro de 2003 



\section{Agradecimentos}

Agradeço à Capes que, a partir de novembro de 2007, contribuiu decisivamente para a realização dessa pesquisa pela concessão da Bolsa de fomento.

Agradeço ao professor e amigo Reginaldo Ronconi pelas contribuições direcionadas ao desenvolvimento desta dissertação.

Agradeço também aos Professores Nabil Bonduki e Joel Felipe pela disposição e considerações apontadas na banca de qualificação, muito importantes para o desdobramento e fechamento do trabalho.

Agradeço aos professores que contribuíram para minha formação ainda nos tempos de graduação, em especial, João Whitaker e Maria Lucia Refinetti Martins pelos anos de aprendizado por meio dos trabalhos do LABHAB-FAUUSP e ao mestre Jorge Oseki (in memoriam) quem me ensinou aprender com humildade e a buscar conhecer sempre mais para compreender os dilemas do mundo.

Agradeço também a equipe da Secretaria Municipal de Habitação de Taboão da Serra, em especial à Ângela Amaral, pelo aprendizado diário da experiência na gestão pública, essencial para desbravar as barreiras do Estado, e vivenciar os limites e as virtualidades da atuação pública no enfrentamento das precariedades e conflitos urbanos para a construção de cidades mais justas. Processo que me fez perceber a distância da crítica acadêmica, e que me proporcionou a aproximação ao tema desta pesquisa.

Agradeço a todos os entrevistados que disponibilizaram um pouco de seu tempo e contribuíram com elementos fundamentais para a construção dessa pesquisa: César Ramos do Ministério das Cidades; Cláudia Gomes e Luciana Royer da CEF; Antônia Pádua, Evaniza Rodrigues, Bismarque Miranda, Dona Bézinha, Ênio Nonato, Modesto Azevedo, Edymar Cintra, Creuzamar Pinho e Cida Tijuwa representantes do movimento popular; Isabel Cabral, Ricardo Gaboni, Leonardo Pessina e Henriqueta Alves assessores técnicos dos movimentos. E ainda, às pessoas que me receberam em Salvador (Elaine, Juliana, Ângela Gordilho, Marli, Eng. Bosco e Ana), em Goiânia (Vidal Barbosa e Thays Lourenço) e em São Paulo (Ricardo Gaboni, Simone Sowmy, Marcel e Paulo Henrique) que me acompanharam no trabalho de campo e disponibilizaram materiais e a experiência vivida dos empreendimentos visitados. 
Aos amigos de sempre peço desculpas pela ausência, aos novos amigos do Planalto agradeço pelo incentivo constante; à amiga Thais Cavalcanti pelo atencioso acolhimento em Salvador, aos amigos Camila Saraiva, Rodrigo (Aladim) Vicino, Fernando Kleiman, Fábio Sanches, Itaque Barbosa, Marcelo Barata e Gustavo Vidigal pelas conversas, reflexões e sugestões que muito contribuíram para essa pesquisa, em especial à Renata Gonçalves e à Débora Cordeiro por dividirmos as inquietações da experiência concomitante de nossos mestrados e à Lara Figueiredo, que mesmo distante esteve muito presente nesse processo, pela leitura e comentários sobre o trabalho.

Aos meus familiares queridos agradeço pelo apoio, em especial a meus pais Léo e Dôdo meu eterno agradecimento por compartilharem com todo carinho, apoio constante e muito incentivo todos os momentos de minha vida e por proporcionarem a possibilidade de percorrer esse caminho. A minha irmã e amiga Andréa por compartilharmos os dilemas da vida e pelo apoio incondicional. Ao meu irmão e amigo Rodolfo pelo carinnho escondido pela idade e pela energia que possui e estimula, que seja também seu estímulo.

E por fim, agradeço imensamente ao Weber, meu amigo e companheiro de vida, por ter me proporcionado a conclusão deste processo com plena dedicação, por compartilhar as inquietudes e reflexões sobre o processo, pelas inspirações e ajudas constantes e concretas. E principalmente, pela paciência, cumplicidade e amor, pelo aprendizado mútuo e entusiasmo diário. 


\section{Resumo}

Esta dissertação busca contribuir para a reflexão a cerca da produção habitacional autogestionária voltada para a população de baixa renda. Para desenvolver essa discussão, primeiro construímos uma abordagem histórica da trajetória do movimento de moradia em torno da apropriação do princípio da autogestão, a partir da política habitacional do Regime Militar ao Governo Lula. Partimos do pressuposto de que o desenho das políticas públicas, particularmente a habitacional, é resultado da disputa de interesses e da interação entre Estado, mercado e sociedade civil. E que a partir dessa interação o movimento popular se formou, amadureceu e passou a interferir na formulação das políticas habitacionais. Assim, o processo de criação do Programa Crédito Solidário, parte integrante da atual Política Nacional de Habitação, não é uma simples reivindicação pontual, mas "um passo" na trajetória decorrente dessa interação. Ao analisarmos os processos de pleito, elaboração, operacionalização e implementação do Programa Crédito Solidário, definido como o "instrumento" de análise para compreender qual a importância da autogestão na política habitacional do Governo Lula, foi possível verificar os limites e potencialidades para a efetivação do princípio da autogestão na atual ação pública habitacional.

Palavras-chave: autogestão; movimento popular; habitação; política pública; governo federal. 


\begin{abstract}
The present dissertation is a reflection about the self-management housing production directed towards the low income population in Brazil. To achieve our objective, we first devoted our research to a historical re-construction of the popular housing movement trajectory and its relation to the self-management principle, inside the national housing policies, from the Military Regime until the President Lula's Government. In this context, we assume that the construction of any public policy, and especially the housing one, is a result of the natural dispute of interests between the Government, the market, and the civil society. Furthermore, we believe that the popular housing movement is a result of this interaction, where it grew, matured, and started to interfere in the housing policies' formulation. Therefore, the creation of the Program of Support Credit, as part of the National Housing Policy, is not a simple punctual claim, but another step in the trajectory resulted from this interaction. In the process of analysis of the of election, elaboration, operation, and implementation of the Program of Support Credit - defined as our instrument of analysis to understand the importance of self-management in the Housing Policy of Lula's Government - we verified the limits and potentialities for an effective use of the self-management principle in the current public housing action.
\end{abstract}

Key-words: self-management; popular movement; housing; policy public; federal government. 


\section{Lista de Figuras, Gráficos, Tabelas e Quadros}

\section{Figuras}

Figura 1: Habitação padrão popular produzida no Brasil pelo BNH (1964-1985): São Paulo e Rondônia

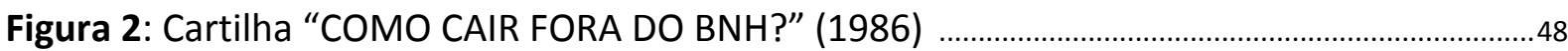

Figura 3: Cooperativas de habitação vinculadas à FUCVAM, no Uruguai, e Mutirões autogeridos do FUNAPS-Comunitário, São Paulo

Figura 4: Entrega das assinaturas do PL do FNMP ao Congresso Nacional (novembro.1991) .62

Figura 5: Cooperativa Shangri-lá e Ipiiba, Rio de Janeiro - RJ . .72

Figura 6: Organograma da operação do Programa Crédito Solidário 108

Figura 7: Empreendimentos do Programa Crédito Solidário

Figura 8: Localização do empreendimento na Malha Urbana - Goiânia . 141

Figura 9: Planta tipo do empreendimento - Goiânia 141

Figura 10: Foto do empreendimento - Goiânia 141

Figura 11: Fotos do empreendimento Fase I e Fase II- Goiânia 141

Figura 12: Localização do empreendimento na Malha Urbana - Salvador 144

Figura 13: Planta tipo do empreendimento - Salvador

Figura 14: Fotos do canteiro em mutirão - Salvador 144

Figura 15: Vista geral do empreendimento - Salvador 144

Figura 16: Localização do empreendimento na Malha Urbana - São Paulo 147

Figura 17: Planta tipo do empreendimento - São Paulo 147

Figura 18: Fotos do canteiro do empreendimento e simulação em maquete eletrônica - São Paulo

Figura 19: Localização do empreendimento na Região Metropolitana - Goiânia 151

Figura 20: Localização do empreendimento na Região Metropolitana - Salvador 151

Figura 21: Localização do empreendimento na Região Metropolitana - São Paulo. 152

Figura 22: Conjunto do PCS em Aparecida de Goiás, isolado da malha urbana. 152

Figura 23: Centros Comunitários dos conjuntos Eldorado Oeste (GO) e Paripe (BA) 162

Figura 24: Empreendimento Parque Sul, João Pessoa, PB 166 


\section{Gráficos}

Gráfico 1: Evolução do investimento federal em habitação (2002 a 2007) ...................................... 92

Gráfico 2: Evolução do emprego formal na construção civil (1999 a 2007) ………………………... 93

Gráfico 3: Distribuição de subsídios do FGTS por faixa de renda ...................................................94

Gráfico 4: Percentual de atendimentos habitacionais com recursos do FGTS por faixa de

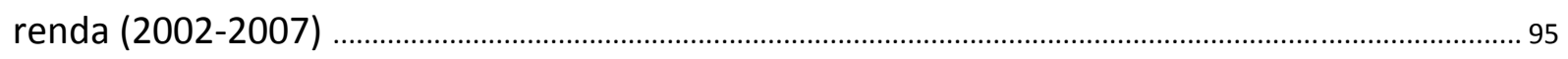

Gráfico 5: Participação dos componentes no déficit habitacional URBANO (2006) - Brasil e Regiões

Gráfico 6: Participação dos componentes no déficit habitacional RURAL (2006) - Brasil e Regiões

Gráfico 7: Distribuição do percentual do déficit habitacional urbano (2006), por tipo de muniípio do PlanHab 127

Gráfico 8: № de Contratos do PCS (2005-2007) distribuídos por região 128

Gráfico 9: Montante de Recursos do PCS (2005-2007) distribuídos por região 130

Gráfico 10: Atendimentos habitacionais do PCS (2005-2007) distribuídos por região 130

Gráfico 11: Programa Crédito Solidário (2005-2007) distribuído por topologia de município do PlanHab

Gráfico 12: Programa Crédito Solidário (2005-2007) distribuído por região 132

Gráfico 13: Distribuição dos percentuais do déficit habitacional urbano (2006) X atendimentos habitacionais do PCS (2005-2007), por tipo de município do PlanHab 133

Gráfico 14: Distribuição dos percentuais do déficit habitacional urbano (2006) X atendimentos habitacionais do PCS (2005-2007), por tipo de município do PlanHab 134

Gráfico 15: Distribuição dos percentuais do déficit habitacional urbano (2006) X atendimentos habitacionais do PCS (2005-2007) e PCS (2008), por região 170

Gráfico 16: Distribuição dos percentuais do déficit habitacional urbano (2006) X atendimentos habitacionais do PCS (2005-2007) e PCS (2008), por tipo de município do PlanHab 171

\section{Tabelas}

Tabela 1: Número de financiamentos habitacionais concedidos pelo SFH/BNH entre 1964 e julho de 1985. 
Tabela 2: Valores referentes aos financiamentos habitacionais concedidos pelo SFH (16642006)

Tabela 3: Atendimentos habitacionais realizados com recursos do SFH (1664-2006) ................66

Tabela 4: Distribuição percentual do Rendimento familiar per capita (2005) .................................78

Tabela 5: Distribuição percentual do déficit habitacional urbano por faixa de renda (2006) ..78

Tabela 6: Investimentos do governo federal em habitação por faixa de renda (1993-2002) ..79

Tabela 7: Valores máximos financiados pelo PCS, conforme modalidade e perfil do município (2004)

Tabela 8: Valores máximos financiados pelo PCS, conforme modalidade e perfil do município $(2005 / 2006)$

Tabela 9: Valores máximos financiados pelo PCS, conforme modalidade e perfil do município (2007)

\section{Quadros}

Quadro 1: Resumo dos programas federais - aquisição e produção - de HIS (2008) ................96

Quadro 2: Desempenho quantitativo do Programa Crédito Solidário ................................................120

Quadro 3: Características Gerais das Tipologias de Municípios do PlanHab ..................................126

Quadro 4: Trabalho de Campo | Empreendimento Eldorado Oeste I |Goiânia - GO..................139

Quadro 5: Trabalho de Campo | Empreendimento Vila Solidária Mar Azul | Salvador - BA...142

Quadro 6: Trabalho de Campo | Empreendimento Colinas da Oeste | São Paulo - SP .145 


\section{Lista de Siglas}

BACEN: Banco Central do Brasil

BNH: Banco Nacional de Habitação

CAAP: Centro de Assessoramento à Autogestão Popular

CCFDS: Conselho Curador do Fundo de Desenvolvimento Social

CCFGTS: Conselho Curador do FGTS

CCU: Centro Cooperativo Uruguaio

CDHU: Companhia de Desenvolvimento Habitacional e Urbano do Estado de São Paulo

CDRU: Concessão do Direito Real de Uso

CEBs: Comunidades Eclesiais de Base

CEF: Caixa Econômica Federal

CGFNHIS: Conselho Gestor do FNHIS

CGP: Confederação Geral dos Trabalhadores

CMN: Conselho Monetário Nacional

CMP: Central dos Movimentos Populares

CNC: Confederação Nacional do Comércio

CNF: Confederação Nacional das Instituições Financeiras

CNI: Confederação Nacional da Industria

COHAB: Companhia de Habitação

CONAM: Confederação Nacional das Associações de Moradores

CONFEA: Conselho Federal de Engenharia, Arquitetura e Agronomia

$\mathrm{CP}$ : Contrapartida

CUEM: Concessão Especial para Fins de Moradia

CUT: Central Única dos Trabalhadores

DEMAHAB: Departamento Municipal de Habitação de Porto Alegre

FAF: Fundo de Aplicação Financeira

FAR: Fundo de Arrendamento Residencial

FAT: Fundo de Amparo ao Trabalhador

FCHA: Fórum de Cooperativas Habitacionais Autogestionárias de Porto Alegre

FCVS: Fundo de Compensação das Variações Salariais

FDS: Fundo de Desenvolvimento Social

FEBRABAN: Federação Brasileira dos Bancos

FGTS: Fundo de Garantia por Tempo de Serviço 
FHC: Fernando Henrique Cardoso

FJP: Fundação João Pinheiro

FNHIS: Fundo Nacional de Habitação de Interesse Social

FNMP: Fundo Nacional de Moradia Popular

FNRU: Fórum Nacional de Reforma Urbana

FRE: Ficha Resumo do Empreendimento

FS: Força Sindical

FUCVAM: Federacción Uruguaya de Cooperativas de Vivienda por Ayuda Mutua FUNACOM: FUNAPS-Comunitário

FUNAPS: Fundo de Atendimento à População Moradora em Habitação Subnormal

HABI: Superintendência de Habitação Popular

HIS: Habitação de Interesse Social

IAB: Instituto de Arquitetos do Brasil

INSS: Instituto Nacional de Seguridade Social

IPEA: Instituto de Pesquisa Econômica e Aplicada

MCid: Ministério das Cidades

MNLM: Movimento Nacional de Luta por Moradia

OGU: Orçamento Geral da União

PAC: Programa de Aceleração do Crescimento

PAIH: Programa de Ação Imediata para Habitação

PAR: Programa de Arrendamento Residencial

PCS: Programa Crédito Solidário

PEP: Plano Empresário Popular

PL: Projeto de Lei

PLANHAB: Plano Nacional de Habitação

PMSP: Prefeitura Municipal de São Paulo

PNH: Política Nacional de Habitação

PRODURB: Programa de Urbanização de Áreas e Regularização Fundiária

PROFILURB: Programa de Financiamento de Lotes Urbanizados

PROHAP: Programa de Habitação Popular

PROMORAR: Programa de Erradicação de Subabitações

PSH: Programa de Subsídio à Habitação

PSM: Produção Social da Moradia

QCI: Quadro de Composição de Investimento 
SAB: Sociedade de Amigos de Bairro

SBPE: Sistema Brasileiro de Poupança e Empréstimo

SDS: Social Democracia Sindical

SEAC: Secretaria Especial de Ação Social

SFH: Sistema Financeiro da habitação

SNH: Secretaria Nacional de Habitação

SNHIS: Sistema Nacional de Habitação de Interesse Social

SNPU: Secretaria Nacional de Programas Urbanos

SPU: Secretaria do Patrimônio da União

TCU: Tribunal de Contas da União

UEMP: União Estadual de Moradia Popular

UH: Unidade Habitacional

UMM-SP: União dos Movimentos de Moradia de São Paulo

UMP-BA: União de Moradia Popular da Bahia

UNMP: União Nacional por Moradia Popular

VF: Valor de Financiamento

VI: Valor de Investimento

ZEIS: Zonas Especiais de Interesse Social 


\section{Sumário}

Resumo

Abstract

Lista de Figuras, Gráficos, Tabelas e Quadros

2. A política habitacional e a autogestão na trajetória do movimento de moradia: do Regime Militar ao Governo FHC

2.1 Ditadura militar: a política habitacional e a organização popular 35

2.2 Autogestão na produção habitacional: a experiência de São Paulo e os mutirões pelo Brasil

2.3 A redemocratização do país na (atmo)esfera local ……………………………………………….....50

2.4 A redemocratização do país na (atmo)esfera federal ……………………………………………...56

2.50 Fundo Nacional de Moradia Popular ………………………………….....................................

2.6 Autogestão pelo país: experiências dos anos 90 ..............................................................................68

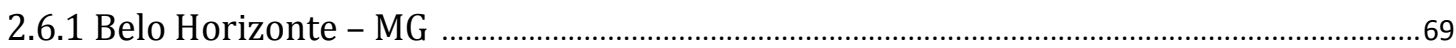

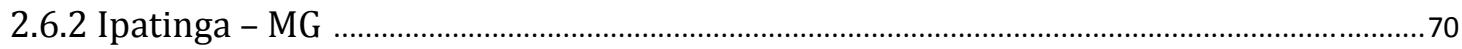

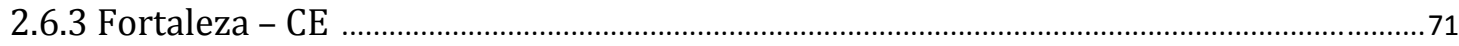

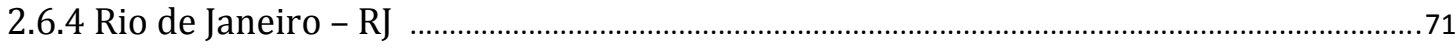

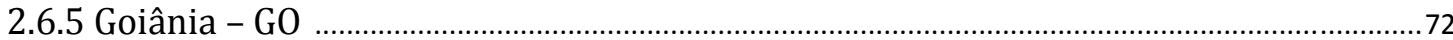

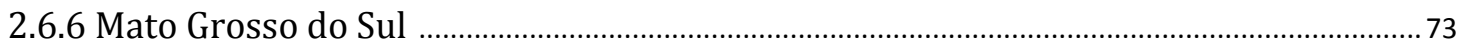

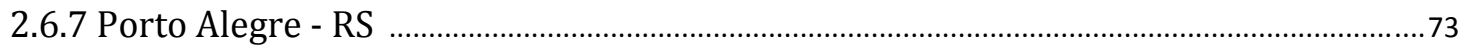

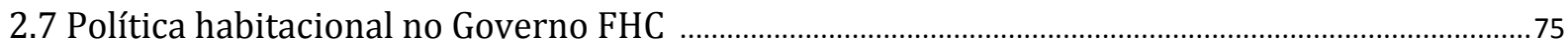

2.8 Sociedade civil modificada e a defesa da autogestão .........................................................................8

2.9 Linha do tempo: política habitacional, autogestão e movimento popular …………………….......83

3. A política habitacional do Governo Lula e o Programa Crédito Solidário …………………....85 
3.1 A Política Nacional de Habitação do Governo Lula

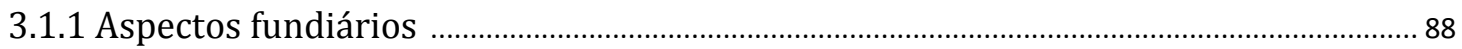

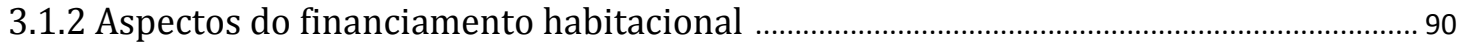

3.1.2.1 Incentivo à atuação do mercado ................................................................................ 90

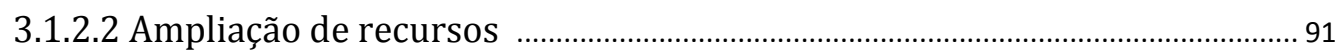

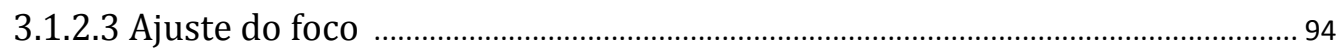

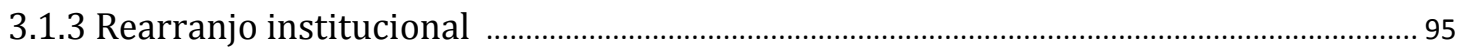

3.1.3.1 Sistema e o Fundo Nacional de Habitação de Interesse Social ....................... 98

3.2 Velhas idéias em outro contexto: o Programa Crédito Solidário ………………………………….... 101

3.2.1 o Fundo de Desenvolvimento Social e o Conselho Curador do FDS ................................ 101

3.2.2 A criação do Programa Crédito Solidário ................................................................................ 104

3.2.3 A operação do Programa Crédito Solidário ....................................................................... 108

4. 0 Crédito Solidário na prática: qual o lugar da autogestão no Governo Lula? …………..... 121

4.1 Análise dos resultados do Programa Crédito Solidário ......................................................................... 123

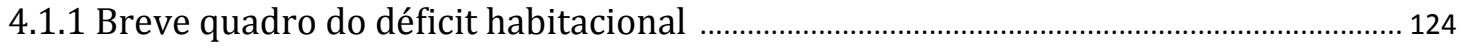

4.1.2 O Programa Crédito Solidário em números …………………………………………...... 128

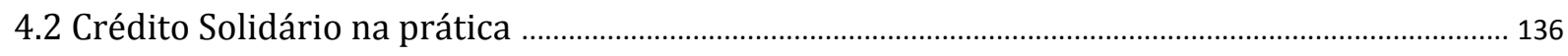

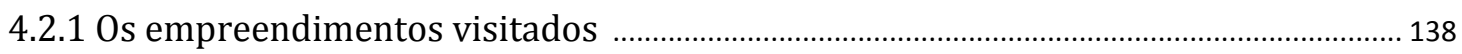

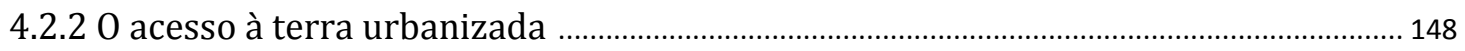

4.2.3 Garantias de risco: "dois pesos e duas medidas" ................................................................... 153

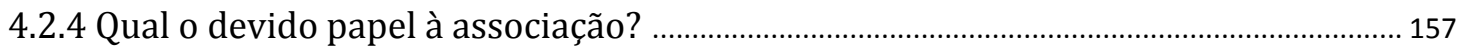

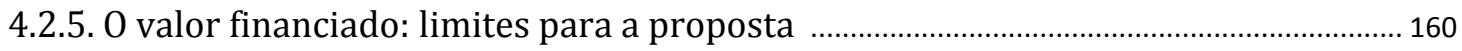

4.2.6 Assessoria técnica: garantia da autogestão e da qualidade das habitações? .............. 162

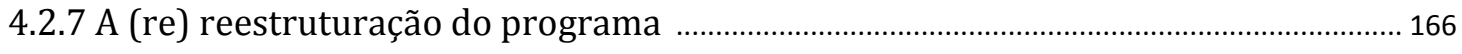

4.3 O lugar da autogestão na política habitacional do Governo Lula ........................................................ 172

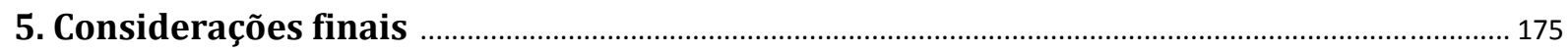

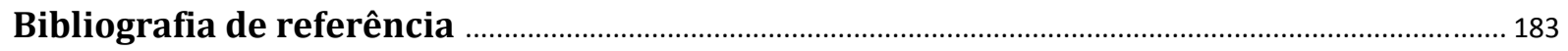

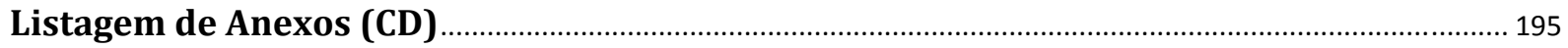




\section{Introdução}

A idéia de que as ações do Estado capitalista são imprescindíveis para garantir a continuidade do processo de acumulação - que só se realiza plenamente quando o Estado busca amenizar os antagonismos presentes na sociedade - foi utilizada para justificar as decisões tomadas pelo Estado nos países centrais. Lá, o Estado do Bem-Estar Social, não só objetivou atenuar os antagonismos da sociedade capitalista, como alargou suas bases ampliando seu mercado consumidor por meio da implementação de diversas políticas sociais (GRANOU, 1975).

No Brasil, onde o desenvolvimento da economia capitalista se realizou sobre as bases escravocrata, patrimonialista e burocrática a implementação das políticas públicas, entre elas a habitacional, respondeu aos interesses da classe dominante em detrimento dos interesses coletivos $^{1}$. E, o que se viu ao longo da história foi o acirramento das desigualdades sociais, da concentração de renda e, conseqüentemente, o estreitamento do mercado consumidor. Sem poder de compra um segmento significativo da população brasileira foi posto à margem da sociedade e teve restringido o acesso a diretos básicos, como a moradia.

No desenvolvimento deste trabalho partimos da história do processo de articulação em torno da política habitacional do regime militar que, conforme apresentada por Melo (1988) explicita a relação entre Estado e mercado². A implantação dessa política gerou impactos no espaço urbano que, atrelados à situação econômica de forte recessão e à fragilização das organizações sociais tradicionais reprimidas pela ditadura (tuteladas e subordinadas ao Estado), propiciaram a formação de novas organizações sociais, entre elas o movimento popular urbano. Ele, a partir do processo de redemocratização do país, se formou enquanto sujeito político (DAGNINO, 1999) e passou a interferir também, na

\footnotetext{
${ }^{1}$ BOLAFFI (1979), VILLAÇA (1986),MARICATO, Ermínia. Política habitacional no regime militar. Petrópolis: Vozes, 1987; MELO (1988), BONDUKI (1998), entre outros.

${ }^{2}$ Cabe esclarecer que limitamos o período de análise a partir dos governos pós-1964, por considerarmos o momento em que o poder público federal propõe de fato a implementação no país de uma política de estado habitacional. Algo ensaiado e não efetivamente estruturado desde os anos Vargas, com os Institutos de Aposentadoria e Pensão (IAPs) e a Fundação da Casa Popular (FCP), conforme exposto por Bonduki (1998) em Origens da Habitação Social: arquitetura moderna, lei do inquilinato e a difusão da casa própria.
} 
formulação das políticas públicas e, a definição das políticas habitacionais que se restringia a interação entre Estado e mercado, alargou-se e passou a ser construída por uma relação tríade entre Estado, sociedade civil e mercado, guardadas as distinções de pesos e medidas.

Quando nos referimos à sociedade civil, partimos do pensamento de Evelina Dagnino (1999) que a define como uma categoria ampla e dinâmica que sofre reformulações no decorrer da história de lutas políticas e sociais do país e, portanto, se difere do Estado e do mercado, mas se inter-relaciona com ambos ${ }^{3}$. E, a partir da concepção tríade (Estado, mercado e sociedade civil) de Habermas, Cohen e Arato ${ }^{4}$ a autora caracteriza sociedade civil como

"campo plural das organizações e relações sociais que apresentam um potencial de mudança nas práticas políticas e sociais, através da tematização pública dos problemas e demandas dos diferentes grupos e setores sociais." (DAGNINO, 1999:35).

A categoria sociedade civil vem responder, nos anos 70 e 80, a identificação comum de diferentes grupos (amplos e plurais) que passam a tornar pública as carências presentes na sociedade, reivindicam liberdades e justiça social. Estes grupos aglutinados por diferentes instituições (igreja católica, grupos de esquerda, sindicatos, entidades profissionais) tinham como elemento articulador o fato de serem organizações autônomas da sociedade. O que significou um marco na organização civil da história brasileira, que até 1964 era tutelada e subordinada ao Estado populista, e passa a ter como unidade a luta contra a ditadura.

A composição ampla da sociedade civil no período ditatorial abarcava desde instituições que desempenhavam papel de denúncia dos diretos humanos e luta pela implantação do estado de direito (como Ordem dos Advogados do Brasil - OAB, Associação Brasileira de Imprensa - ABI e Conferência Nacional dos Bispos do Brasil - CNBB), os movimentos sociais de "demandas universais" que reivindicavam a mudança de padrões das relações sociais e de comportamento (como movimento feminista, homossexuais, ecologistas e de igualdade racial) e ainda, aqueles que disputavam o acesso a direitos a partir de novas práticas políticas, como os movimentos populares urbanos. Dagnino (1999)

\footnotetext{
${ }^{3}$ Vale destacar que não estamos tratando de uma visão determinista dessas categorias. Elas são compostas por uma diversidade de esferas e atores com valores e práticas distintas e ora se diferenciam, ora se aproximam de cada uma dessas categorias.

${ }^{4}$ Habermas, J. Between facts and norms. Cambridge, MIT Press, 1996 e COEHN, J e ARATO, A. Civil society and political Theory. Cambridge and London, MIT Press, 1992.
} 
destaca ainda, que os setores populares desempenharam papel central no interior da sociedade civil ao buscar transformações políticas e sociais, papel antes protagonizado prioritariamente pelo proletariado.

O termo sociedade civil organizada que teve neste primeiro momento forte conotação de oposição ao regime ditatorial, após a redemocratização do país ganha novo significado, como campo próprio capaz de contribuir, formular, interferir e ser parte da ação pública. Já no decorrer dos anos 90 e 2000, passa a abarcar outros significados, divergentes entre si, como o associativismo, fortalecido pela onda neoliberal, que estabeleceu novas relações associativas e tomou para si a as atribuições das políticas sociais que deveriam ser de responsabilidade do Estado.

Ao definirmos como objetivo da pesquisa analisar o programa habitacional, que tem como particularidade a autogestão, reivindicado pelo movimento de moradia e respondido pelo Estado, adotamos como perspectiva de análise o olhar voltado para a interação entre Estado e sociedade civil organizada. Consideramos que essa interação trata-se de uma dupla construção em que os atributos da ação dos Governos interferem (de maneira positiva ou negativa) no amadurecimento das relações sociais e na qualidade de institucionalização da sociedade civil, que por sua vez, causa, com diferentes potenciais, interferência na ação pública (RIBEIRO, 1995:15). Essa dupla construção é capaz de gerar uma esfera pública (mais ou menos) viva, conforme o grau de comprometimento do Estado e amadurecimento da sociedade civil.

Ao abordarmos a formação social do movimento popular urbano, parte integrante da sociedade civil organizada, partimos da compreensão de que ela é composta pelas dimensões econômica, cultural e política. Trata-se de uma compreensão adotada por diversos teóricos, como SHERER-WARREN (1987), SADER (1988) e outros, para interpretar as organizações e lutas sociais que se formavam no contexto de politização da sociedade ao final da ditadura brasileira, e que consideraram adequada a apropriação de alguns conceitos trazidos por Thompson ${ }^{5}$. Entre eles a concepção do autofazer-se das classes sociais ao longo da história, tratada como processo dinâmico e ativo decorrente da ação humana e das

\footnotetext{
${ }^{5}$ Até então prevalecia análises que se apoiavam no marxismo estruturalista, certos autores brasileiros consideram adequada à apropriação de alguns conceitos trazidos por Edward Thompson em $A$ formação da classe operária inglesa, v.1. Rio de Janeiro: Paz e Terra, 1987, que ao estudar a formação da classe operária inglesa valorizou as dimensões culturais e políticas, além da dimensão econômica.
} 
condições materiais existentes. Segundo Sígolo (2007:24) recuperando Laclau (1986) ${ }^{6}$, essa nova perspectiva trouxe a noção de experiência e com ela, a percepção de sujeitos sociais, plurais e autônomos a qual demonstrou que apenas a abordagem por meio da luta de classes não era suficiente para compreender os conflitos sociais da sociedade contemporânea.

Considerando que essas dimensões estão relacionadas entre si, a dimensão cultural segundo Scherer-Warren (1987) foi responsável por dar forma à organização e à práxis da sociedade civil dos anos 70 e 80 , a qual intitulou como "novos movimentos sociais". Entre os aspectos componentes dessa dimensão estava primeiro, o reconhecimento do povo (que escapa às delimitações de classe), das condições materiais do capitalismo e das diversas formas sobrepostas de opressão (para além das relações de produção), entre elas as determinadas no espaço urbano ${ }^{7}$. E segundo, a apropriação de certos princípios formadores de sua base crítica apoiados nas idéias caracterizadas pela "democracia de base, livre organização, autogestão, direito a diversidade e respeito a individualidade, identidade local e regional e noção de liberdade coletiva" (SCHERER-WARREN, 1987:40), em resposta a insatisfação ao autoritarismo ${ }^{8}$.

A leitura feita pela autora era de que esses movimentos dos anos 70 e 80 apesar de proporem uma nova forma de ação política por vezes pouco conscientes, em resposta as condições políticas e econômicas daquele momento ${ }^{9}$, apresentaram ambigüidades e muitas

\footnotetext{
${ }^{6}$ LACLAU, Ernesto. Os novos movimentos sociais e a pluralidade do social. In: Revista Brasileira de Ciências Sociais, no 2, vol. 1, out. 1986.

${ }^{7}$ O conceito de espoliação urbana trazido por Lucio Kowarick em A espoliação urbana. Paz e Terra, Rio de Janeiro, 1979,(p.59) trata dessas formas de opressão: “... é o somatório das extorsões que se opera através da inexistência ou precariedade de serviços de consumo coletivo que se apresentam como socialmente necessários em relação aos níveis de subsistência e que agudizam ainda mais a dilapidação que se realiza no âmbito das relações de trabalho" citado por BARBOSA (2008:15).

${ }^{8}$ Estes princípios podem ser identificados no discurso, e em certos aspectos da prática, da União Nacional de Moradia Popular, um dos principais agentes desse estudo, como a autogestão como elemento fundamental de sua reivindicação que abarca a democracia de base e liberdade coletiva, direito a diversidade (ao abrigarem núcleos que lutam pela igualdade de gêneros e igualdade racial), e respeito a individualidade (ao abrigarem núcleos GLBT), respeitam a identidade regional, ao ser composta por organizações de diferentes estados com práticas distintas.

${ }^{9}$ Descrições apontadas por SINGER e BRANT (1980); GOHN, Maria da Glória. Reivindicações Populares Urbanas: Um estudo Sobre a Sociedade Amigos de Bairros de São Paulo. São Paulo: Ed. Cortez, 1982; JACOBI, Pedro. Movimentos populares urbanos, poder local e conquista da democracia. In Cidade, Povo e Poder. Rio de Janeiro, Cedec/Paz e Terra, 1982; CARDOSO, Ruth. Movimentos sociais urbanos: balanço crítico. In: SORJ, ALMEIDA, (org.). Sociedade e política no Brasil pós-64. São Paulo: Brasiliense, 1983; SADER (1988), e outros.
} 
vezes esbarraram nas formas patriarcais de fazer política e em limites impostos pelas estruturas tradicionais, e com isso enfrentavam dificuldades para colocar em prática certos princípios e avançar, a passos mais largos, na direção das transformações sociais.

Nesse sentido o papel desempenhado por agentes formadores e apoiadores ${ }^{10}$ foi fundamental para que fosse atribuída maior qualidade a sua dimensão política, justificando a observação da autora, de que estava sendo "formado um lastro social importante para a construção de uma nova cultura política de base no Brasil"' (SCHERER-WARREN, 1987:49). As Comunidades Eclesiais de Base (CEBs), instituições essencialmente leigas, “... cuja inspiração central é estabelecer o relacionamento solidário entre os homens, conforme um modelo democrático de autogestão" (SINGER e BRANT, 1980:78) desempenharam papel fundamental na organização e formação do lastro social dos movimentos populares. Mas elas também vivenciaram a ambigüidade estabelecida pelo convívio do "novo" com a tradição e se defrontaram com limites. Justamente por estarem sob a proteção institucional da igreja católica e possuírem valores e formas de interação com o mundo diferentes daqueles segmentos conservadores da Igreja dominados pela hierarquia e patriarcalismo.

Apesar da sensatez demonstrada por Scherer-Warren ao salientar que

"os novos movimentos sociais não apresentam projetos bem definidos para o futuro, mas parece-me que estão construindo as bases para uma vida mais democrática e mais socializada" (SCHERER-WARREN, 1987:50),

talvez, em decorrência do forte otimismo que marcou o processo de redemocratização do país a partir de meados dos anos 80 ,

"estes movimentos foram saudados em sua espontaneidade, como novos sujeitos políticos portadores de nova identidade sócio-cultural, com contornos de projeto político voltado para a transformação social e a radical renovação da vida política" (DOIMO, 1995 apud BARBOSA, 2008:16).

Em 1986 Marilena Chauí apontou as razões que justificavam o vácuo de cidadania na sociedade brasileira:

"É porque a política brasileira é relação de tutela e de favor, e porque nela o espaço público é tratado como espaço privado dos dominantes, que não há cidadania no

\footnotetext{
${ }^{10}$ CEBS, assessores técnicos e sociais, até mesmo assessores vinculados aos partidos políticos.
} 
pais, embora (...) haja movimentos sociais e populares para alcançá-la." (CHAUÍ, 1986:136)

Fica evidente o caráter revolucionário atribuído pela autora aos movimentos sociais que foram, em grande medida, responsáveis pelos avanços conquistados, por ampliar as fronteiras da política (antes restritas às setores da elite política) e por trazer de volta o debate sobre a esfera pública. Entretanto, e talvez o distanciamento histórico nos permita afirmar que, atribuir esse peso e responsabilidade aos movimentos sociais e populares seja ao menos um equívoco.

A luta pela conquista de direitos sociais, civis e políticos, e a luta pela cidadania preencheram o campo de disputa política deste período, especialmente em torno da constituinte de 1988, quando foi posta a necessidade de estabelecer um novo projeto ao Estado a partir de novas formas de gestão em que prevalecessem a democracia, a transparência, a autonomia local, a participação popular e sistemas de autogestão, em direção da construção de uma sociedade mais cidadã e includente. Na nova constituição federal foram conquistadas novas formas de participação direta na vida política do país, a partir da constituição de conselhos gestores de políticas públicas, a possibilidade de criação de projeto de lei de iniciativa popular, audiências públicas, plebiscitos e referendos.

A defesa da participação popular nos processos decisórios estava fortemente relacionada à visão de que pela via institucional, seria possível reverter o quadro de exclusão sócio-econômica e política que marca a história do país, e que se tornou mais evidente na ditadura militar. Isso porque foi o período em que o desenvolvimento conservador e concentrador adotado pelos militares levou, apesar do crescimento econômico (entre 1967 e 1973), ao acirramento da desigualdade social, à restrição do acesso dos segmentos populares aos direitos básicos (em função dos desenhos das políticas públicas) em prol da preponderância dos interesses das classes dominantes.

A efetivação desses mecanismos político-institucionais na esfera federal pouco avançou ao longo dos anos $90^{11}$, mas foram experimentados na esfera local em diversas gestões de esquerda, a partir dos primeiros sinais da descentralização participativa como os conselhos municipais de saúde, habitação, meio ambiente, educação, e ainda os orçamentos

\footnotetext{
${ }^{11}$ Apesar da regulamentação do Sistema Único de Saúde em 1990, por exemplo.
} 
participativos. A partir dessas experiências sucederam diversas reflexões, entre elas o debate levantado por Abreu e Leite, a respeito do arranjo institucional que respondia

“... a visão 'conselhista' de participação estruturada a partir dos 'movimentos combativos', privilegiava a organização de aparelhos de poder em detrimento da organização da cultura e da disputa hegemônica." (ABREU; LEITE, 1992:36).

Trata-se de uma perspectiva que impôs aos movimentos sociais da época, a necessidade real de participação numa esfera democrática que exigia preparação, capacitação e institucionalização, pois nela estavam envolvidas a disputa e negociação de interesses e a formulação de propostas. Prática que não fazia parte do repertório eminentemente combativo dos movimentos de então.

Essa estratégia de democratização pelo viés "conselhista" sem que fosse proposto pelas gestões municipais um projeto político de emancipação, segundo os autores, gradativamente dispensou dos partidos políticos de esquerda e dos movimentos sociais a perspectiva de luta pela hegemonia.

O dilema identificado na década de 90 nas dinâmicas municipais se colocou, nos últimos anos, de maneira similar na esfera federal decorrentes dos novos arranjos e articulações entre Estado e sociedade civil e da ampliação dos espaços institucionais de participação política propostos pelo atual Governo. O pragmatismo, as posturas corporativas dos segmentos de representação e, por vezes, a cooptação têm se sobreposto às perspectivas mais estratégicas.

Na argumentação proposta por Abreu e Leite (1992), a gênese desse processo pode ser identificada no ideário socialista que se formou das lutas políticas e sociais ainda do século XIX. Quando se lutava, pela perspectiva emancipatória, contra a alienação e submissão do trabalhador às condições sociais impostas pelo capitalismo e ao funcionalismo do Estado, instrumentalizado pela burguesia. Porém, a visão negativa do Estado e das relações que dividem a sociedade civil (governados) dos governantes, foi sendo restringida progressivamente à luta do operariado contra os interesses da burguesia e o Estado mantenedor do sistema capitalista:

“... o socialismo deixou de ser pensado como uma mediação necessária à emancipação dos homens e da sociedade (...) Gradativamente, adquiriu um sentido 
mais estreito: o domínio do poder estatal pelo proletariado ou, mesmo, por um partido em seu nome." (ABREU; LEITE, 1992:40).

Assim, temos que a partir do processo da democratização do Estado brasileiro (que permitiu ampliar a cidadania a segmentos populares por meio dos canais institucionais de participação) e, em função do deslocamento da centralidade do processo político antes na sociedade para o Estado, o que se viu foi o antagonismo entre a inserção institucional daqueles até então marginalizados politicamente (movimento sociais e partidos de esquerda) e o sentido emancipatório de sua ação política.

Além das dimensões abordadas até aqui, a dimensão espacial apresenta fundamental importância para a compreensão da formação social do movimento popular urbano, por tratar-se de uma particularidade que o distingue dos demais movimentos sociais: o espaço urbano, como espaço político, lugar e objeto de estratégias de disputas (LEFEBVRE, 1970).

O primeiro elemento que está relacionado à dimensão espacial diz respeito a formação dos grupos associativos que se organizavam de forma autônoma a partir de uma identidade ou demanda definida pela territorialidade, no momento de forte repressão em que os partidos estavam proibidos em se organizar e os sindicatos sob controle da ditadura militar. As CEBs principais interlocutoras, apoiadoras e incentivadoras dessas organizações (apesar da sua atuação não se restringir aos movimentos que lutavam pelas questões urbanas), também eram estabelecidas pela territorialidade. E ainda hoje a maior parte dos movimentos de moradia se organiza a partir dos grupos de origem que nascem dos bairros.

O segundo elemento relaciona-se às ações e reivindicações do movimento popular, inicialmente com as ocupações coletivas de terra, posteriormente com as reivindicações por melhores condições de vida (acesso à infra-estrutura e serviços urbanos, regularização da posse), até a disputa para garantir o direto à cidade.

Essas ações foram responsáveis por publicizar a disputa que se dá em torno do espaço urbano, que passa pelo acesso a direitos, e materializa no território a desigualdade social e racial presentes em nossa sociedade. Apesar da diminuição lenta e gradativa do quadro da desigualdade social no Brasil $^{12}$, atualmente, os $10 \%$ mais ricos ainda detém $75 \%$

\footnotetext{
${ }^{12}$ Com base em (BRASIL/IPEA/SPI-MP 2007b:27) o coeficiente de GINI (que mede comparativamente o nível de desigualdade entre países do Mundo, e varia de 0 e 1 pontos) entre o início dos anos 80 e o ano de 2001
} 
da riqueza nacional (BRASIL/IPEA, 2008:18). A desigualdade é agravada na comparação por raça, quando em 2007 os negros e pardos eram 73,5\% dos $10 \%$ mais pobres e $11,6 \%$ do $1 \%$ da população mais rica do país (BRASIL/IPEA, 2007b:28-29).

A sociedade desigual se mostra na cidade pela exclusão do direito à moradia digna. Em 2006, as famílias com renda familiar até três salários mínimos representavam 90,7\% da demanda por habitação do país (BRASIL/MCID/SNH, 2008). Em 2007, mais de 54 milhões de brasileiros moravam em condições precárias de habitabilidade, representando $34,5 \%$ da população brasileira. E novamente o aspecto racial se faz presente quando entre os brasileiros, os pretos e pardos são $47,6 \%$ e sofrem mais com os problemas habitacionais: eles são $66,3 \%$ dos moradores de cortiços e $65,6 \%$ dos moradores de favelas do país (BRASIL/IPEA, 2008).

A dimensão espacial revela aspectos da dimensão econômica que envolve a formação social do movimento popular urbano. Não é difícil supor que as motivações que levam a população de baixa renda a compor essencialmente a base social do movimento popular urbano são as privações de direitos e de condições materiais para viver. Essas famílias vêem na luta coletiva a possibilidade de superação da condição de exclusão e em certa medida, impõe ao movimento a premência de uma ação pragmática, e justificada, na direção de soluções concretas.

A conquista de direitos básicos, dentre outros a moradia, passa então a significar a possibilidade de inserção à sociedade, mesmo que venha ser feita de maneira frágil e inconclusa, e impõe contraditoriamente limites significativos ao potencial papel transformador da sociedade atribuído ao movimento popular.

Há de se reconhecer que o movimento popular ao mesmo tempo em que atua na esfera reivindicativa pela conquista da moradia, não deixa de agregar os valores de uma sociedade mais justa como a diminuição da desigualdade, o direito à diversidade, o respeito à individualidade e a construção da cidadania ativa. E nem tão pouco deixa de apontar as necessidades de transformar as formas de apropriação e produção do espaço urbano (quando, por exemplo, ocupam imóveis vazios para denunciar a não aplicação da função social da propriedade urbana). 
Como veremos no primeiro capítulo, o movimento popular, a todo o momento almeja (e aceita) ampliar seus horizontes de luta, incorporando novos princípios a cada ciclo de amadurecimento, principalmente, em decorrência da qualidade da interação com o Estado. Definido como sujeito político, composto pela pluralidade de sujeitos sociais, o movimento popular é formado e transformado pelas suas próprias experiências que atribuem a ele a heterogeneidade como característica essencial.

Particularmente, a experiência ocorrida na gestão municipal de São Paulo (19891992) oriunda do Programa Funaps-Comunitário, que viabilizou a produção habitacional pelos mutirões autogeridos por grupos organizados, contribuiu para o avanço do movimento popular na cidade e revelou o compromisso daquele governo em buscar o resgate da dívida pública com os setores populares. Apesar dos limites vivenciados, essa experiência despertou virtualidades e possibilidades que a nosso ver minimizavam os antagonismos entre a inserção e o sentido da ação emancipatória ${ }^{13}$ ao contribuir para qualificar a ação do movimento popular. Ainda que a proposta tenha nascido do Estado, o que se pretendia era colocar a sociedade (o homem) de volta à centralidade do processo político, por meio do instrumento denominado autogestão.

"A autogestão deve ser estudada de duas formas diferentes: como 'meio de luta', abrindo caminho, e como 'meio de reorganização da sociedade', a transformação da vida cotidiana e do Estado." (LEFEBVRE, 1966 apud NASCIMENTO, 2007:37).

O conceito de autogestão apropriado como meio de organização produtiva e social esteve presente no início do século XIX com as formulações dos socialistas utópicos Robert Owen (Inglaterra) e Charles Fourier (França), quando propuseram outros modelos de produção alternativos ao modelo capitalista de então (SINGER, 2002). Ao longo da história a autogestão também foi apropriada e experimentada por diversos movimentos políticos, sociais e econômicos como meio de luta política, como a Comuna de Paris (1871), os

\footnotetext{
${ }^{13}$ Sobre essa experiência trataremos com detalhes no primeiro capítulo dessa dissertação, baseado em RONCONI (1995), AMARAL (2001), FELIPE (1997), ARANTES (2002), CARVALHO (2004). Sobre o assunto ver outras referências não citadas bibliografia desse trabalho, como: FASE-SP. Mutirões autogestionários: levantamento de obras 1989-1995. São Paulo: FASE-SP, s/d; VAZ, Ana Luiza. Mutirão Habitacional autogestionário: a experiência da CAAP na grande São Paulo, 1980-1990, Dissertação de Mestrado, PUC-SP, 2000 e COMARU, Francisco. Intervenções habitacionais em Cortiços na cidade de São Paulo, o mutirão Celso Garcia. Dissertação de Mestrado EPUSP, 1998.
} 
Conselhos Operários da Hungria e Polônia (1953-1956), o governo da lugoslávia (a partir de 1950), na Argélia (1962), a Comissões de trabalhadores em Portugal durante Revolução dos Cravos (1974), o Chile de Allende (1972) dentre outras experiências, cujos formatos e motivações para sua organização foram os mais diversos possíveis, porém sempre marcados por conjunturas de grandes lutas sociais (NASCIMENTO, 2007:31-33).

O termo, no entanto, foi utilizado pela primeira vez na década de 60 na França, como uma tradução direita de samoupravlje (samo: auto e upravlje: gestão), para fazer referência ao processo político que ocorreu na lugoslávia durante o governo Tito em contraposição ao stalinismo soviético (GUILLERM; BOURDET, 1976:11). Mas ao longo da história a palavra ganhou diferentes tonalidades de acordo com o contexto social, político, cultural e econômico em que a prática ocorreu. Assim, "O próprio da autogestão é ter sido um movimento social antes de ser uma doutrina" (ROSANVALLON, 1976, apud NASCIMENTO, 2007:29).

A máxima fundamental da autogestão, segundo Guillerm e Bourdet é a igualdade entre as pessoas, "Se os homens fossem desiguais de fato e de direito, não haveria dificuldade em admitir que uns comandassem os outros" (1976:46). E continuam,

“... uma organização social que não aliena (nem submete, nem humilha) homem algum, só pode repousar no princípio da igualdade absoluta de todos os membros que a compõem e, mais ainda, sobre a liberdade inteira de cada um" [grifo do autor] (1976:53),

e , portanto, não dependente da imposição de algo alheio a tal organização como, "Deus, rei, sábio legislador ou genial paizinho dos povos" (1976:53).

Os autores sustentaram ainda, com base na teoria do contrato social recuperada de Rousseau (século XVIII) apenas como um instrumento de análise que, por meio dos princípios da igualdade e liberdade "... todos os membros do corpo social (...) criam contratualmente uma lei geral (e isso será a autonomia) que os organiza sem gerar entre eles diferenças de poder..."14.

\footnotetext{
${ }^{14}$ Ao aproximarmos as idéias trazidas por GUILLERM e BOURDET (1976:53) com o contrato social da prática dos empreendimentos habitacionais autogeridos, temos que tal contrato social seria nada mais do que o Regulamento de Obras construído e aprovado coletivamente pelos membros da associação de mutirantes.
} 
Em 1966, Henri Lefebvre apontou algumas reflexões em torno de questões teóricas relacionadas à autogestão:

"A experiência social (prática social) mostra que as associações de autogestão surgem nos 'pontos frágeis' da sociedade existente. Toda a sociedade tem seus 'pontos fortes' que no conjunto, formam a armadura, a estrutura da sociedade." (LEFEBVRE, 1966 apud NASCIMENTO, 2007:35).

O autor sugere que os "pontos fortes" são as estruturas pelas quais o Estado está consolidado e que a todo o momento se esforça para eliminar possíveis contradições, fissuras (pontos frágeis) que possam vir a surgir e a fragilizá-lo. Essas fissuras, por sua vez, se revelam pela ação de grupos ou indivíduos, que por meio de ação social podem provocar "abalos" ao conjunto, que venham acarretar em um novo arranjo de forças.

É justamente por isso que, para Lefebvre, a autogestão não acontece a qualquer momento e lugar, e depende assim, de uma conjuntura propícia para que se possa efetivar. Ao mesmo tempo, o autor reforça que o princípio da autogestão apropriado e experimentado por grupos sociais deve colocar em questão a própria existência do Estado: “... a autogestão não pode evitar esta difícil tarefa: construir-se em poder que não seja estatal" (LEFEBVRE, 1966 apud NASCIMENTO, 2007:36).

A partir desse referencial teórico, nos deparamos com algumas contradições ao realizar a transposição do campo teórico para o prático - a experiência da produção habitacional autogerida da gestão municipal de São Paulo (1989-1992) viabilizada pelo Programa FUNAPS-Comunitário. A autogestão, neste caso, partiu de uma iniciativa provocada pelo Estado, ao propor uma nova forma de interação, parceira, com a sociedade civil, e que proporcionou a criação consentida de novos espaços de poder ao propiciar às famílias que compõem os grupos organizados de mutirantes

“... conhecer outros espaços políticos que antes Ihes eram completamente vedados. É aí que a consciência da sua própria atuação política cresce, na medida em que percebe como se dão as lutas nas diversas esferas" (RONCONI, apud SILVA, 1994:31).

Ou seja, para viabilizar ou difundir tal experiência foi preciso um contexto propício, distinto daquele enunciado por Lefebvre: 
“... tal proposta só é possível na medida em que o Estado abra mão do seu poder, de sua competência e divida essa competência e repasse os recursos para a sociedade." (RESCHKE apud SIVA, 1994:34)

A autogestão nessa experiência teve a potencialidade de funcionar como um instrumento de transformação das pessoas em sujeitos de sua história ${ }^{15}$, ao abrir brechas que proporcionam a emancipação em relação aos processos alienantes presentes nas relações sociais, familiares, na escola, no trabalho. Essa prática pode também ser considerada como um instrumento de conquista da cidadania ${ }^{16}$ quando,

“... participar de discussões e decisões do coletivo ao qual está associado, educa e conscientiza, tornando a pessoa mais realizada, autoconfiante e segura." (SINGER, 2005:21).

A participação no processo de autogestão coletivo deu indícios de que os sujeitos sociais podem influenciar no processo decisório e interferir nos resultados concretos conforme seus interesses e vontades, respeitadas as opiniões alheias e consensuadas. Entretanto, como ressaltado por Paulo Conforto em entrevista, participar e decidir sobre sua própria vida e a do grupo que faz parte, trata-se de uma ação facultada a cada um dos indivíduos envolvidos.

"Se a pessoa não quiser exercer, não exigir, não tenha dúvida que outra pessoa vai exercer por ela. (...) Então, dentro de uma comunidade, você pode ter duzentas pessoas fazendo um mutirão, você pode ter autogestão de meia dúzia ou você pode ter autogestão de duzentos; dependendo de quantos são aqueles que vão exigir seu direito de participar e de influir." (CONFORTO apud SILVA, 1994:81).

Na prática os graus de empoderamento, liberdade e igualdade são distintos de grupo para grupo e de indivíduo para indivíduo. Bem como o grau de consciência de cada um sobre a importância do processo de gestão coletiva e de sua potencialidade. E em função disso, ressaltamos, que a autogestão é uma construção constante, pois, seja qual for o processo autogerido pressupõem-se a necessidade de um processo de educação e formação democrática, para a tomada de consciência e de fortalecimento político.

\footnotetext{
${ }^{15}$ Referência a fala de Ana Lucia Vaz em entrevista a Ana Amélia Silva (1994:42).

${ }^{16}$ Segundo Pedro Demo (1992:17), a cidadania “... é um processo histórico de conquista popular através do qual a sociedade adquire, progressivamente, condições de tornar-se sujeito histórico consciente e organizado, com capacidade de conceber e efetivar projeto próprio".
} 
Sem a mudança da cultura política, pela qual apontamos as ambigüidades inerentes à formação social do movimento popular e sua interlocução com o Estado, Paul Singer (2005:21) destaca que o êxito desses processos (no sentido mais amplo) pode estar em risco, pois os aspectos alienantes presente em nossa sociedade induzem a todo o momento a degenerações e distorções da prática autogestionária.

Considerando a exposição acima, o propósito de produzir uma pesquisa que trouxesse contribuições para ampliar a reflexão sobre a evolução dos programas habitacionais autogeridos, voltados para a população de mais baixa renda, foi o que inicialmente motivou a elaboração da discussão apresentada nesse trabalho ${ }^{17}$.

O fator novo que justificou a elaboração de mais um estudo sobre a proposta autogestionária na produção habitação já debatida por diversos autores, foi partimos de um novo contexto, em que o governo federal passa pela primeira vez a ser dirigido por um campo de esquerda, com a eleição em 2002 do Presidente Luis Inácio Lula da Silva. E pela criação do Ministério das Cidades, estrutura institucional que passou a apoiar e fomentar a reformulação da Política Nacional de Desenvolvimento Urbano e Habitacional pautada pelos princípios defendidos pelo movimento social da reforma urbana, a começar pela formalização de canais institucionais de participação social que deram voz ao movimento popular.

"Nós queremos que vocês ajudem a propor, que vocês exijam, que vocês nos empurrem (...) Não se importem com as nossas caras feias. Cobrem o que é direito de vocês." (Presidente Lula, Abertura da 1ạ Conferência nacional das Cidades, 23 de outubro de 2003).

Respondendo as expectativas do movimento, justificada pela possibilidade concreta implementar na prática as propostas que por anos, ao menos na esfera federal, representavam apenas bandeira de luta do movimento popular (entre elas a autogestão na produção habitacional), o Governo cria em 2004 o Programa Crédito Solidário.

\footnotetext{
${ }^{17}$ Além do contexto federal, outros aspectos também foram responsáveis por motivar a escolha da temática a ser abordada pela presente pesquisa: o interesse pelo tema despertado ainda na faculdade e a experiência na gestão pública municipal (Secretaria de Habitação do município de Taboão da Serra entre os anos de 2005 e 2007) na qual participei da atividade de fomento e parceria com movimento organizado da cidade, entre outros processos, responsável por buscar viabilizar um empreendimento habitacional por meio do Programa Crédito Solidário.
} 
Único programa inteiramente novo formulado no Governo Lula, justamente para responder a reivindicação do movimento popular, inspirada em velhas idéias, de um programa que viabilizasse o atendimento de famílias de baixa renda, no qual as associações e cooperativas fossem os agentes operadores do processo e tivessem a liberdade de gerir os recursos destinados à produção de suas próprias moradias.

Assim, o objetivo principal desse trabalho foi analisar o porquê e como as velhas idéias foram concretizadas nesse novo contexto do governo federal que apresenta uma série de particularidades. Vale ressaltar que o propósito dessa pesquisa não foi promover uma avaliação do Programa, mas a partir dele, analisar como foi o processo de apropriação da proposta autogestionária à Política Nacional de Habitação do atual governo federal.

Para isso definimos que seria preciso compreender os processos de pleito, elaboração, operação e implementação do Programa Crédito Solidário, a partir da mediação de interesses dos principais agentes envolvidos: o movimento popular e as instituições do Estado - o Ministério das Cidades e a Caixa Econômica Federal - partindo do pressuposto que,

“... as instituições são centrais no estudo da política não apenas pela importância do Estado como ator e autor de ações específicas, mas porque ele, assim como as demais instituições políticas, influenciam diretamente a cultura política, a estratégia dos atores e a produção da própria agenda de questões a serem objeto de políticas, enquadrando a luta política através das suas instituições." (MARQUES, 1997 apud BARBOSA, 2008: 31).

Para construir essa compreensão nos apoiamos no referencial bibliográfico, nas entrevistas realizadas com os diferentes agentes envolvidos no processo, nas informações institucionais, e nos dados obtidos por meio do trabalho de campo realizado em três empreendimentos viabilizados pelo Programa Crédito Solidário. E a partir daí, buscamos responder: como se deu a participação do movimento popular na elaboração do Programa Crédito Solidário? E em que medida o programa respondeu à proposta original pleiteada pelo movimento? Qual o grau de importância atribuída ao PCS considerando as demais ações da Política Nacional de Habitação? E qual seu impacto no déficit habitacional? E por fim, considerando que as potencialidades inerentes à autogestão quando apropriada pelas políticas habitacionais e urbanas, em que medida o processo autogestionário foi de fato 
apropriado pelos agentes envolvidos? E, em que medida tem atribuído a esses processos de produção habitacional um diferencial de qualidade, seja do espaço físico como das relações sociais?

Os três capítulos seguintes a essa introdução que se propôs discorrer sobre o referencial teórico que subsidiou a reflexão sobre movimento popular urbano e a autogestão, compõe a estrutura da dissertação apresentada da seguinte forma:

O primeiro capítulo aborda as políticas habitacionais, a partir da interação entre Estado e movimento popular. A discussão que tem o foco na esfera federal (ao tratarmos das políticas de habitação do Regime Militar até o Governo Fernando Henrique Cardoso) foi permeada por fatos contundentes ocorridos na esfera local em diferentes regiões do país, com o propósito de buscarmos construir uma abordagem histórica da trajetória do movimento de moradia, sua formação e atuação, em torno da apropriação do princípio da autogestão.

O segundo capítulo trata dos aspectos mais relevantes, relacionados à nossa discussão, presentes na política habitacional do Governo Lula como os aspectos fundiários, do financiamento habitacional e arranjo institucional da política, e ainda apresenta o processo de elaboração e operacionalização do Programa Crédito Solidário, parte integrante da atual Política Nacional de Habitação, com foco na interlocução entre os agentes envolvidos.

O terceiro capítulo apresenta uma análise do Programa Crédito Solidário desenvolvida a partir dos elementos decorrentes de sua efetivação prática, com o propósito de compreender os limites e potencialidades encontrados no processo de sua implementação, e com isso compreender qual a importância da autogestão na política habitacional do Governo Lula.

E por fim, nas considerações finais buscamos apresentar uma síntese dos principais aspectos analisados e dos argumentos apresentados, como contribuição ao debate sobre a autogestão, e os limites e potencialidades para sua efetivação decorrente da ação pública habitacional. 


\section{A política habitacional e a autogestão na trajetória do movimento de moradia: do Regime Militar ao Governo FHC.}

A Introdução da proposta da autogestão na produção habitacional protagonizada na cidade de São Paulo foi exaustivamente trabalhada e debatida por diferentes autores e por diferentes enfoques ${ }^{1}$. Não se pretende aqui retomar esta rica história em suas minúcias, mas sim atribuir sua devida importância ao discorrermos sobre de que maneira, a partir dessa experiência, a idéia da autogestão se propagou na trajetória do movimento de moradia até chegar às portas do governo federal, com base em alguns exemplos espalhados pelo território brasileiro. Para isso retomou-se a história das políticas habitacionais implantadas no país na esfera federal, a partir de 1964 com o início do Regime Militar até final do governo Fernando Henrique Cardoso em 2002, buscando encadear fatos e argumentos que sustentem a construção histórica da formação e atuação do movimento de moradia.

\subsection{Ditadura Militar: a política habitacional e a organização popular}

A partir de meados do século XX um abrupto processo de urbanização das principais cidades brasileiras em função da industrialização crescente transformou o Brasil rural, em pouco mais de 20 anos, em um país predominantemente urbano ${ }^{2}$. O contingente populacional que chegava às cidades enfrentou grandes dificuldades para contornar a inexistência de estoque habitacional, e foi levado a empreender por diferentes maneiras soluções que nem sempre se davam de forma adequada e satisfatória.

A condição de vida precária das favelas e cortiços somada à maneira como o Estado tratava a questão da habitação foram catalisadores das primeiras iniciativas populares que buscavam resistir aos processos autoritários e violentos das políticas de desfavelamento.

\footnotetext{
${ }^{1}$ Cf. BONDUKI (1992), RONCONI (1995), FELIPE (1997), AMARAL (2001), ARANTES (2002), CARVALHO (2004), entre outros.

${ }^{2}$ Com Base em IBGE, em 1950 o Brasil tinha sua população distribuída em 36\% da população urbana e 64\% da população rural. Em 1980, 68\% da população brasileira viviam nas cidades e 32\% na área rural.
} 
Brasília Teimosa ${ }^{3}$ no Recife, Pirambú ${ }^{4}$ em Fortaleza e Brás de Pina ${ }^{5}$ no Rio de Janeiro foram casos emblemáticos de moradores que se organizaram resistindo aos processos de remoção das famílias para conjuntos habitacionais construídos pelo poder público nas áreas periféricas das cidades.

No início dos anos 60 a questão urbana entra em discussão em meio a crise econômica e cenário político permeado de incertezas e esperanças com Jango à presidência. Em julho de 1963, o IAB organizou em Petrópolis - RJ, um seminário do qual resultou um documento que apontava diretrizes para formulação de uma Política Habitacional e de Reforma Urbana a ser incorporada por Projeto de Lei elaborado pelo Executivo. Os principais aspectos desta proposta contemplavam a criação de órgão executor da política habitacional e de um fundo nacional de habitação, bem como a elaboração de um plano nacional de habitação e de um plano de gestão territorial (SOCRATES, 1986).

Meses depois o presidente João Goulart, apesar de todas as fragilidades políticas que permearam seu governo, anunciou a campanha pelas reformas de base, entre elas a Reforma Urbana que tomava menor expressão do que as demais no Brasil que ainda se percebia como país agrário, por mais que o veloz crescimento urbano já acarretasse

\footnotetext{
${ }^{3}$ A área foi ocupada a partir de 1947 entre os bairros do Pina, de Boa Viagem e área do porto de Recife. 0 nome Brasília Teimosa foi dado em homenagem à cidade de Brasília, na época em construção, e por causa da resistência dos habitantes do bairro em não deixar a área muito cobiçada, situada na região valorizada da capital, tendo resistido também a incêndios possivelmente criminosos. A área passou por processos de urbanização ainda no final do período $\mathrm{BNH}$, e atualmente está em processo de finalização das obras de urbanização que resultou na eliminação das palafitas e remoção de parte das famílias para o novo bairro de Cordeiro à $6 \mathrm{~km}$ do centro de Recife. (informações extraídas site da Fundação Joaquim Nabuco, www.fundaj.gov.bre www.recife.pe.gov.br).

4 “...é significativa a precocidade de um movimento que se articula em Fortaleza, já em 1959, em torno do problema da moradia. Conforme depoimento, a favela Pirambu, uma das maiores do Brasil ("só perde pra Rocinha" segundo Beto Cabral, educador do CDPDH da Arquidiocese de Fortaleza), protagonizaria uma das primeiras histórias de disputa e ocupação organizada de terra urbana já entre 1958 e 1962 . Mobilizados em torno da resistência a inúmeras tentativas de remoção, o assentamento permanece no mesmo local às custas de mecanismos consolidados de organização popular autônoma para a produção (horta de ervas medicinais e farmácia fitoterápica), prestação de serviços (pousada e terapias medicinais) e educação (creche, escola de teatro, atividades de complementação escolar etc." (LOPES; RIZEK, 2005:10).

${ }^{5}$ A partir de 1960 quando Carlos Lacerda era governador do estado da Guanabara, as favelas do Pasmado, do Bom Jesus, de Maria Agú e de Brás de Pina entram como prioridades nas intervenções municipais e seus moradores são removidos para os conjuntos Vila Kennedy e Vila Aliança. Na gestão seguinte, Brás de Pina foi a única favela a passar por processo de urbanização, isso porque "a política de erradicação da administração estadual precedente sofreu, neste local, um grande revês. Sob um forte impacto midiático da associação de moradores, com o apoio do pároco local, impediu a destruição da favela". Fruto de ação conjunta entre BNH e Companhia de Desenvolvimento de Comunidades do Rio a ação previa urbanização de espaços públicos internos à favela, aporte financeiro e técnico aos moradores para reforma ou construção das casas. (SANTOS, 1980).
} 
problemas nas principais cidades. Em 10 de abril de 1964, os militares tomaram o poder e produziram profundas mudanças em relação às orientações anunciadas pelas reformas sociais do presidente deposto. Por cerca de 40 anos as diretrizes que pautavam a reforma urbana permaneceriam distantes da política urbana e habitacional propostas para o país.

Os militares assim que tomam o poder propõe a implementação de uma política de estado para o setor habitacional, algo que vinha sendo ensaiado e não efetivamente estruturado desde os anos Vargas (BONDUKI, 1998). Segundo Melo (1988) em seu artigo Classe, burocracia e intermediação de interesses na formação da política de habitação, a política habitacional proposta foi resultado da disputa de poder e de idéias entre os populistas conservadores, que buscavam legitimar o regime, e os capitalistas que buscavam acumular capital, ambos por meio da produção da casa própria.

A proposta inicial da política nacional de habitação ${ }^{6}$, defendida por Sandra Cavalcanti, tinha como referência o Programa da COHAB-Guanabara, baseado na atuação das Companhias de Habitação Popular. Segundo a então presidente do BNH, esta seria a única maneira de intervir junto aos setores de menor renda, já que pelo Programa COHAB as construtoras eram contratadas pelo Estado, para realizar estritamente a execução de obras dos empreendimentos habitacionais, cabendo às Companhias de Habitação direcionar os critérios de atendimento.

Segundo Melo (1988), nesse formato, os lucros dessas empresas ficariam restritos ao processo produtivo das edificações, muito menores se comparado aos lucros que poderiam ser obtidos da apropriação da renda fundiária, bem como do processo de comercialização das unidades habitacionais ${ }^{7}$. Assim, respondendo à demanda do empresariado da construção civil, do setor de crédito financeiro, da indústria de material de construção e dos bancos comerciais ${ }^{8}$ o regime aprova a Lei de Incentivo a Indústria da Construção Civil $^{9}$, redirecionando as diretrizes da proposta inicial.

\footnotetext{
${ }^{6}$ A Lei no 4.380 de 21 de agosto de 1964 cria o SFH, o BNH e todo o aparato institucional, determinando as diretrizes básicas da política habitacional deste período.

7 Michael Ball (1992) ao analisar a cadeia produtiva da habitação, afirma que os processos baseados na atividade mercantil (por ser essencialmente uma atividade especulativa) são responsáveis pelos ganhos efetivos do setor imobiliário. Especialmente, quando a indústria da construção civil é caracterizada por ser artesanal e rudimentar e, portanto, de baixa produtividade.

${ }^{8}$ Segundo Melo (1988), este segmento argumentava que para criar as bases da produção em massa de habitação era preciso fazer altos investimentos no setor da construção de edificações. A partir disso, seria
} 
O setor da construção civil passou, a partir de então, a atuar fortemente no Sistema Financeiro de Habitação, porém como se sabe, sua atuação nunca alcançou as classes de menor renda. Segundo Bolaffi (1979), os ganhos das instituições financeiras e dos bancos comerciais foram gigantescos, em especial entre os anos do milagre econômico ${ }^{10}$.

Os agentes privados se beneficiaram do desenho da política de habitação adotada pelo governo militar, afirmando assim a hegemonia do capital privado, tanto em relação à abrangência do poder de influência deste setor nas tomadas de decisões, quanto em relação aos benefícios alcançados em função da forma de operação desta política.

O objetivo da simples acumulação de capital pelo setor privado, aliada à liberdade de decisão sobre a produção das unidades habitacionais empreendidas pelos diversos agentes privados operadores dos financiamentos do BNH resultaram em conseqüências dramáticas às cidades brasileiras e também à população "beneficiária" deste produto, se é possível denominá-la assim, já que foram poucos os efetivos benefícios trazidos a ela. Segundo Bolaffi, "... a burla se inicia com a utilização de terrenos inadequados e mal localizados", segue com a implantação feita com grandes movimentações de terra, “... prossegue na construção de edificações imprestáveis e se conclui com a venda da casa a quem não pode pagá-la, por preços freqüentemente superiores ao valor de mercado" (BOLAFFI, 1979:54).

O foco da produção resultante dos interesses do setor privado estava no lucro que poderia ser obtido a cada unidade habitacional a mais levantada, sem que houvesse a intenção de promover o efetivo desenvolvimento da indústria da construção civil, que poderia proporcionar lucro pela produtividade (em detrimento da especulação), e possivelmente, melhora da qualidade das edificações construídas.

Assim, a questão habitacional foi tratada de forma descolada de quaisquer diretrizes de desenvolvimento urbano, dada a falta de qualidade da inserção do novo conjunto ao

\footnotetext{
possível modernizar a estrutura produtiva do setor, que aliada a um desenho "adequando" de financiamento de crédito ao beneficiário final, poderia resultar na sonhada ampliação do seu campo de intervenção, que até então se restringira a alta renda. Aparentemente, o que se objetivava era alargar o mercado do setor da indústria da construção civil, ao abocanhar o atendimento das classes médias e baixas.

${ }^{9}$ Lei Federal no 4.864 de 1965.

${ }^{10}$ Com base em Melo (1988) entre 1966 e 1967 a arrecadação do BNH cresceu cerca de 700\% em função da criação do FGTS e outras medidas que acarretaram no aumento dos recursos disponíveis à aplicação na produção habitacional, oriundos, por exemplo, do SBPE. As instituições aprovadas tinham a permissão de reter por 30 dias os recursos do FGTS.
} 
bairro, ou a inserção do novo bairro à malha urbana existente. Essa lógica de produção de cidades, ocorreu nos mais diferentes cantos do país difundido um "padrão de habitação popular".
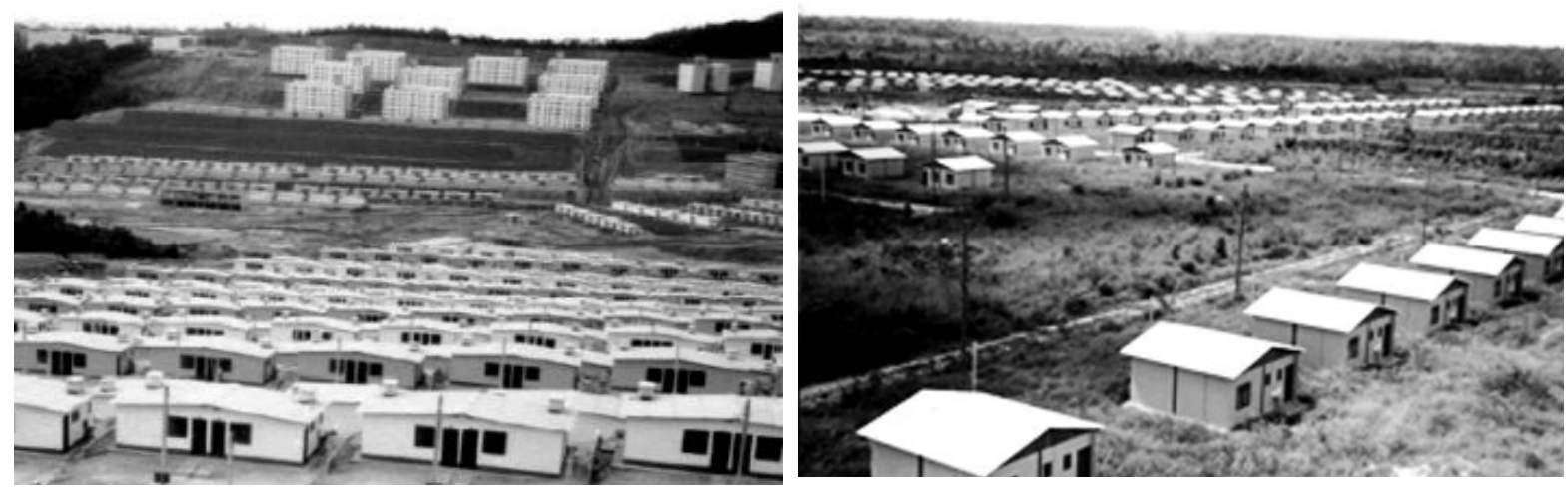

Habitação padrão popular produzida no Brasil pelo BNH (1964-1985): São Paulo e Rondônia.

$\mathrm{O} \mathrm{BNH}$, desde sua criação, foi diminuindo a aplicação de recursos do SFH à habitação popular transferindo-os para a produção de infra-estrutura e para habitação de alto e médio padrão, segundo Maricato “... buscando evidentemente atingir um mercado com poder aquisitivo que pudesse fazer frente aos preços dos imóveis, e às taxas de juros e correções monetárias..." (MARICATO, 1979:80).

Ao final de 22 anos de atuação, apesar do significativo número de 4,8 milhões de unidades habitacionais produzidas, apenas $18 \%$ do total dos recursos investidos pelo $\mathrm{BNH}$ foram direcionados às famílias com renda inferior a cinco salários mínimos (BOLAFFI, 1986 apud ARANTES, 2002). No caso da Grande São Paulo essa população representava na época cerca de 85\% (MARICATO, 1979:85) do total dos moradores que, excluídos da política nacional de habitação, empreenderam a partir da autoconstrução na periferia a conquista de sua casa própria ${ }^{11}$.

O Brasil, pela forte dependência do capital externo, ficou vulnerável à crise econômica decorrente do primeiro choque do petróleo, em 1973. O governo Geisel, para

\footnotetext{
${ }^{11}$ Conforme apresentado pelo roteiro do filme Fim de Semana, de 1976, elaborado por Maricato o processo de autoconstrução se caracteriza pela localização em loteamentos periféricos, muitas vezes irregulares, desprovidos de infra-estrutura, onde era utilizado a mão de obra familiar, sem qualificação para a construção das unidades habitacionais, fazendo uso de materiais de baixa qualidade, sem acompanhamento técnico e sem seguir as normas dos códigos de edificações. Somados ao longo período demandado para a execução da obra, a autoconstrução proporcionou edificações inseguras e insalubres.
} 
enfrentar os efeitos regressivos e aumento da inflação, recorreu a empréstimos internacionais e optou pela substituição da importação de bens de capital e insumos básicos (celulose, petróleo, álcool, entre outros). E entre outras medidas, promoveu a desaceleração da construção civil, acreditando na interpretação de que o superaquecimento do setor imobiliário estava estimulando o processo inflacionário.

A partir de então, foi atribuído à política de habitação uma papel periférico no bojo das diretrizes macroeconômicas ${ }^{12}$. Buscando responder às pressões econômicas decorrentes desse cenário econômico e contornar os desgastes políticos dos anos mais pesados da ditadura, o governo federal propôs uma revisão da estrutura orientadora das ações do BNH divididas em três frentes: o Mercado Popular, o Mercado Econômico e o Mercado Médio ${ }^{13}$.

O redirecionamento da aplicação dos recursos para as necessidades habitacionais das famílias com renda inferior a cinco salários mínimos ocorreu de maneira efetiva a partir 1975, com a produção em escala de grandes conjuntos habitacionais populares sob a responsabilidade das $\mathrm{COHABs}^{14}$ e pelos programas denominados reformistas ou alternativos.

No momento em que os subsídios não entravam no hall de mecanismos para viabilizar o atendimento das famílias de baixa renda e os critérios financeiros eram determinantes na formulação dos programas, o BNH buscou diminuir os custos das intervenções e criou novas linhas de financiamento. Destinadas à produção de lotes urbanizados, à compra de materiais de construção e à assistência técnica, apoiando desta maneira as iniciativas de autoconstrução já existentes, respondeu oportunamente, às

\footnotetext{
${ }^{12}$ Segundo BOLAFFI (1979) o pedal acelerador para reativar a economia nunca foi o setor da construção civil, e sim o setor da indústria de bens de consumo duráveis, em especial a automobilística (que neste momento, também ganha papel coadjuvante nas definições macroeconômicas). Afirma que se fosse diretriz do governo investir na produção habitacional respondendo a tal propósito, a recuperação econômica seria mais lenta, porém provavelmente resultaria numa estruturação mais duradoura. Segundo o autor, o regime sustentou "falsos problemas" para garantir os interesses políticos e da hegemonia da classe dominante, o chamado "problema da habitação", que não passou de artifício político adotado para enfrentar um problema econômico conjuntural.

${ }^{13} \mathrm{O}$ primeiro voltado às faixas de renda de zero a três salários mínimos, cuja ação era operada pelas COHABs, o segundo voltado às faixas de três a seis salários mínimos operados pelas cooperativas e, por fim, o terceiro atuando para faixas de renda maiores do que seis salários mínimos sendo que, neste caso, as operações eram realizadas por agentes privados. Com base em SACHS, Celine. São Paulo: política pública e Habitação Popular. São Paulo, Edusp, 1999 apud ROYER (2002).

${ }^{14}$ Como exemplo da cidade de São Paulo, a explosão dos grandes conjuntos habitacionais dessa época ocorreram na COHAB Itaquera e COHAB Jardim Bonifácio.
} 
pressões por maior participação da população nos programas públicos. Os atendimentos realizados pelo PROFILURB ${ }^{15}$, entretanto, representaram apenas $10 \%$ do total de moradias empreendidas no mesmo período pelos Programas Convencionais (CARDOSO, 1993 apud, FELIPE, 1997).

Em 1979, foi criado o Programa de Erradicação de Subabitações - PROMORAR, no momento em que as pressões dos movimentos de favela que resistiam às políticas de desfavelamento e brigavam pelo acesso à água, luz e regularização da situação da posse fundiária se intensificavam. O PROMORAR veio substituir o PROFILURB, ampliando suas frentes de intervenção. Por um lado, numa linha preventiva buscando evitar o aumento de novas favelas, promovia a abertura de novos loteamentos populares com a implantação de infra-estrutura básica acrescida de embrião habitacional, e por outro, ao reconhecer que não seria possível eliminá-las somente com programas de remoção de favelas, o Estado passou a promover processos de urbanização de algumas áreas, financiando aquisição de materiais de construção para melhoria das unidades (ROYER, 2002).

Em 1984, o BNH criou o Programa Nacional de Autoconstrução/ Projeto João-deBarro que institucionalizou a prática da autoconstrução assistida enquanto política pública. Em seu pouco tempo de existência atendeu principalmente famílias com renda inferior a 1,5 salários mínimos do interior dos municípios do Nordeste do país (SACHS, 1999 apud CARVALHO, 2004).

As práticas clientelistas que se reproduziram localmente pela forma como eram conduzidas as decisões sobre a alocação dos recursos, foram duramente criticadas. Bem como, os aspectos relacionados à qualidade das intervenções realizadas pelo PROMORAR, e posteriormente pelo João-de-Barro. As definições desses programas estavam alinhadas às diretrizes de financiamento apontadas pelo Banco Mundial aos países de terceiro mundo com base nas idéias liberais de John Turner. Segundo o autor era necessário uma mudança de postura do Estado dado sua incapacidade operacional assim, atribuía a ele, apenas as ações legislativas e administrativas; delegando a ação de prover a habitação à população por meio de empreendimentos auto-organizados, auto-construídos e auto-administrados

\footnotetext{
${ }^{15}$ Em 1975, o BNH lança o PROFILURB (Financiamento de Lotes Urbanizados) a fim de estabelecer uma ação preventiva contra o crescimento das favelas. Por ele seriam produzidas "tramas saneadas". Em 1978 o programa foi modificado e além da infra-estrutura implantada seriam financiados também os núcleos hidráulicos da unidade habitacional.
} 
(LOPES; RIZEK, 2005) ${ }^{16}$. Entretanto, pode-se questionar se o problema estava na capacidade operacional do Estado ou nas diretrizes adotadas por ele.

O fato dos critérios financeiros prevalecerem em relação aos sociais nas definições das diretrizes das políticas habitacionais, inclusive dos programas alternativos, produziu o conceito das moradias progressivas. Um produto inacabado a ser finalizado com mão de obra do futuro morador como o produto "mais adequado" às famílias de menor renda, pois só assim, diminuindo os custos e produzindo "escândalos"17, o BNH poderia efetivar esse atendimento (ROSSETTO, 1993 apud ROYER, 2002).

\section{Tabela 01}

Número de financiamentos habitacionais concedidos pelo SFH/BNH entre 1964 e julho de 1985

\begin{tabular}{|c|c|c|c|}
\hline \multirow{2}{*}{ PROGRAMAS } & & EMPRESTIMOS & \multirow{2}{*}{ EM \% } \\
\hline & & CONCEDIDOS & \\
\hline \multirow{3}{*}{ Mercado Popular } & Programas Convencionais (COHABs) & 1.235 .409 & $27,70 \%$ \\
\hline & Programas Alternativos* & 264.397 & $5,90 \%$ \\
\hline & Total & 1.499 .806 & $33,60 \%$ \\
\hline \multirow{3}{*}{ Mercado Econômico } & Cooperativas & 488.659 & $10,90 \%$ \\
\hline & Outros Programas** & 299.471 & $6,70 \%$ \\
\hline & Total & 788.130 & $17,60 \%$ \\
\hline \multirow{4}{*}{ Mercado Médio } & SBPE & 1.898 .975 & $42,50 \%$ \\
\hline & Outros Programas $* * *$ & 280.418 & $6,30 \%$ \\
\hline & Total & 2.176 .393 & $48,80 \%$ \\
\hline & Total SFH & 4.467.329 & $100 \%$ \\
\hline
\end{tabular}

fonte: Saches, Celine. São Paulo: Políticas Públicas e Habitação Popular. Edusp: SP, 1999. apud Royer, 2002.

*Promorar, João-de-barro, Ficam, Profilurb

**Instituto, Hipoteca, Empreend. P/Pron., Prosin

*** Recon, Prodepo

Pode-se dizer que o governo militar foi responsável pela separação entre os movimentos denominados "tradicionais" e as novas formas de organização popular. Conforme descrito por Scherer-Warren (1987: 41) os antigos canais de participação

\footnotetext{
${ }^{16}$ Com base em Housing By People publicado em 1976, por John Turner, onde o autor desenvolve as principais idéias sobre $o$ assunto.

${ }^{17}$ Ermínia Maricato, em entrevista realizada à Revista Proposta no 35. Rio de Janeiro: FASE-RJ, Ano XII, Set/1987, descreve que a produção feita pelo PROMORAR era de habitações de $22 \mathrm{~m}^{2}$ "... que foi um escândalo em termos de qualidade" (p.31).
} 
pautados pela subordinação e tutela do Estado, como as $\mathrm{SABs}^{18}$ e os sindicatos, foram fortemente reprimidos ao longo da ditadura militar, e perderam a importância na atuação junto aos bairros. O que não significa que as posturas mais tradicionais tenham desaparecido, elas estão presentes ainda hoje em muitas organizações, em decorrência das raízes da cultura política brasileira fortemente marcada pelo patriarcalismo e patrimonialismo.

Foi no interior deste mesmo Estado que, paulatinamente, os moradores dos bairros populares e favelas das cidades, apoiados pelas intervenções de agentes formadores, como as Comunidades Eclesiais de Base, militantes de esquerda, clube de mães e outros, passaram a apropriar-se do "direito de conquistar e (gerir) direitos" ${ }^{19}$ a partir da percepção das carências presentes na vida cotidiana. O Estado antidemocrático, ao negligenciar sua responsabilidade em promover habitação digna e serviços de consumo coletivo adequados à reprodução da força de trabalho, construiu os elementos motivadores da organização popular em torno de ações reivindicatórias voltadas às melhorias das condições de vida nas cidades $^{20}$, no contexto de piora das carências urbanas decorrente da recessão econômica que levou ao empobrecimento da população.

A população organiza-se, sai dos bairros e vai para as ruas reivindicar e, estabelece segundo Jacobi uma

“... nova maneira de relacionar o político e o social, o mundo público e a vida privada, na qual as práticas cotidianas se incluem.(...) Reivindicam direitos numa perspectiva de apropriação igualitária de bens de consumo coletivo e de cidadania, ou de formas mais adequadas de vida nas cidades" (JACOBI, 1989:18-19).

Entretanto, os aspectos fracionados, particulares e imediatos dessas primeiras iniciativas de organização popular revelaram um quadro estreito de suas reivindicações, que não conseguiam alcançar às contradições materiais e objetivas presentes na estrutura da sociedade brasileira.

\footnotetext{
${ }^{18}$ As Associações de Amigos de Bairro e Sociedades de Amigos de Bairro (SABs) criadas a partir da década de 30 eram identificadas como responsáveis pela barganha do voto em troca de melhorias urbanas relacionada às necessidades de infra-estrutura, pelo recrutamento de cunho clientelista e pela cooptação de lideranças ao longo dos governos populistas.

${ }^{19}$ Expressão contida na Revista Proposta no 29 citada por SCHERER-WARREN (1993:55).

20 Implantação das redes de saneamento, transporte público, creches, postos de saúde, entre outras demandas.
} 


\subsection{Autogestão na produção habitacional: a experiência de São Paulo e os mutirões pelo Brasil}

A década de 80 foi marcada pelo agravamento da crise econômica devido a forte recessão, crescimento dos índices inflacionários, desvalorização do valor real dos salários, crescimento do desemprego e subemprego, e consequentemente, o empobrecimento da população. A população de menor renda, mais afetada pela crise econômica, encontrava cada vez mais dificuldades para acessar a moradia, especialmente pelo elevado custo da terra urbana.

As famílias que buscavam sair do aluguel em função da explosão dos valores ${ }^{21}$, completamente descompassados aos reajustes salariais, tiveram que recorrer às soluções precárias dos cortiços e favelas que tiveram neste período crescimento espantoso ${ }^{22}$. Isso se deu pelo fato das famílias não encontrarem alternativas formais, fosse pela contínua retração de investimentos do SFH, como pelo resultado insignificante da reorientação dos investimentos do $\mathrm{BNH}$ aos programas alternativos ${ }^{23}$. A restrição ao acesso à terra nas áreas periféricas como alternativa informal, em função da Lei Federal no 6.766 de $1979^{24}$, contribuiu também para agravar o inchaço das favelas nesse período.

Em meio à maior crise habitacional que afetava os principais centros urbanos do país a população, cada vez menos esperançosa sobre as possibilidades de acesso à casa própria, passa a se reunir e se organizar para reivindicar outras soluções. O fato do solo urbano ser um componente essencial à produção habitacional fez das ocupações coletivas de terra uma forma de pressionar o poder público para a obtenção dessas soluções.

As primeiras grandes ocupações coletivas de terras que ocorreram isoladamente em diferentes regiões da cidade de São Paulo, e em diferentes capitais estaduais ${ }^{25}$, em sua

\footnotetext{
${ }^{21}$ Segundo dados da EMBRAESP apresentados por Maricato (1988) os preços dos aluguéis entre 1981 e 1986 , em São Paulo, alcançaram uma valorização de $500 \%$.

22 Com base CACCIA BAVA em "As ocupações de terra e a igreja em São Paulo" ANPOCS, 1987; Maricato (1988) apresenta que em São Paulo entre 1973 e 1983 a população moradora em favelas cresceu cerca de 630\%, e entre 1975 e 1981 a população moradora em cortiços cresceu aproximadamente 800\%.

${ }^{23}$ A Tabela 01 demonstra que os atendimentos feitos pelos programas alternativos representaram menos de $6 \%$ do total dos financiamentos concedidos pelo BNH ao longo dos 22 anos de funcionamento.

${ }^{24}$ A Lei no 6766 de 1979 passou a tratar da matéria do parcelamento do solo urbano e criminalizar a ação dos loteadores clandestinos.

${ }^{25} \mathrm{O}$ uso das ocupações de terras de forma organizada e coletiva trata-se, ainda hoje, de um instrumento de mobilização, reivindicação e pressão utilizado pelos movimentos de moradia nos diferentes centros urbanos do
} 
maioria apoiada pela Igreja Católica e posteriormente por partidos políticos, foram violentamente reprimidas. Em meio aos ares da ditadura militar, "O Estado age como guardião da propriedade privada, defensor da ordem burguesa e dos interesses do capitalismo monopolista." (MOYSES, 2001:02).

Porém, gradativamente crescia a organização da população impondo um caráter mais coletivo às ocupações, buscando evitar ações individuais oportunistas. ${ }^{26}$ Coordenadas por lideranças e apoiadas por profissionais progressistas, as ocupações coletivas serviram para publicizar os problemas da habitação e do restrito acesso à terra, colocando em questão o direito de propriedade (BONDUKI, 2003). E, funcionaram como importante instrumento por meio de negociação com os governos municipal e estadual para alcançar suas bandeiras de luta: a desapropriação da terra e o acesso a financiamento público para construção de habitações por meio de mutirão.

O Estado, ao se dispor a negociar com a população organizada, a reconhece enquanto interlocutora de interesses coletivos (JACOBI, 1989). Todavia, não foram poucos os momentos em que ele deixou a interlocução de lado e fez uso da violência para impor sua autoridade, garantir a lei e a perpetuação de interesses particulares.

$\mathrm{O} \mathrm{BNH}$ ao longo de todo regime militar centralizava o destino dos recursos do SFH, distribuindo entre outros agentes para os estados e municípios, estes por sua vez, investiam

país. O que os diferencia é o período em que essa forma de luta foi utilizada nos diferentes estados brasileiros, conforme o grau de urbanização de cada lugar, grau das necessidades habitacionais apresentadas e do estágio de organização de cada um dos movimentos de moradia. Em entrevistas com as lideranças dos movimentos de moradia de diferentes regiões do país (São Paulo, Belo Horizonte, João Pessoa, Palmas, Manaus, São Luiz, Goiânia e Mato Grosso do Sul) esse artifício de luta esteve presente em todas as falas.

Exemplos desses processos foram relatados por Antonia de Pádua da CMP de Belo Horizonte em entrevista realizada em 27 de fevereiro de 2008, "Nós começamos nosso movimento em 1986, 1987. A gente começou nossa movimentação com ocupação de terras...". E por Vidal Barbosa, liderança da UEMP-Goiás em entrevista realizada em 15 de outubro de 2008, que relatou que a partir de 1979 ocorreram diversas ocupações organizadas pela União das Invasões que realizava ocupações coletivas em áreas vazias de Goiânia, como o Jardim Nova Esperança e Jardim Boa Sorte, essa última violentamente reprimida e sem êxito. A última grande ocupação desse período foi do Parque Anhanguera, com mais de 1.500 famílias: “... nós invadíamos, montávamos a lona e preparávamos para o despejo, porque eles iam para o despejo". A partir de 1982 cria-se a União dos Posseiros Urbanos que passa a reivindicar a regularização de cerca de 190 áreas ocupadas e a produção de moradias.

${ }^{26}$ Em FELIPE (1997) a exemplo da Fazenda da Juta, na zona Leste de São Paulo, cerca de 5.500 famílias pertencentes ao grupo dos sem-terra ocuparam a área desordenadamente, e sem uma coordenação por trás do processo ocorreu o inchaço descontrolado da área. Desse episódio tirou-se que na ocupação seguinte, no Jardim Colorado, as famílias deveriam erguer barracões comunitários, fato que demonstrou que o movimento tinha o interesse prioritário em negociar com o poder público. 
uma ínfima parte dos recursos orçamentários próprios em habitação ${ }^{27}$. Após as primeiras eleições diretas de 1982, várias prefeituras e governos estaduais não puderam mais contar com os recursos do SFH, já em crise, e passaram a recorrer ao mutirão como solução, barata, para driblar a pressão por habitação. Para as famílias, o mutirão também surge como alternativa que poderia garantir maior qualidade à produção habitacional feita com os parcos recursos disponíveis ${ }^{28}$.

Em São Paulo, entre 1982 e 1985 nos governos de Franco Montoro (estado) e Mario Covas (município), em decorrência de um casamento de interesses ocorreram as iniciativas pioneiras de caráter experimental de produção habitacional por meio de mutirão, e onde se esboçava a possibilidade do controle das famílias nas decisões de projeto e do processo de trabalho na obra, realizada a partir de recursos públicos (da $\mathrm{COHAB}$ ou da $\mathrm{CDH}$ ) e com apoio técnico feito por profissionais externos ${ }^{29}$. Entre elas estavam a experiência da Vila Nova Cachoeirinha (1982), do Recanto da Alegria (1983) e da Vila Comunitária de São Bernardo $(1985)^{30}$

Essas experiências foram objetos de diversos debates e análises aprofundadas, e não é nosso propósito retomar tais discussões. Vale destacar que no contexto em que se buscava novas soluções para a grave crise habitacional, a influência do cooperativismo uruguaio no desenvolvimento dessas propostas foi essencial por demonstrar que seria possível obter ótimos resultados na qualidade das habitações produzidas, a menores custos com a participação das famílias envolvidas diretamente no processo.

\footnotetext{
${ }^{27}$ Ermínia Maricato em entrevista a Revista Proposta no 32, (1987).

${ }^{28}$ Em resposta às escandalosas moradias produzidas pelo PROMORAR.

${ }^{29}$ O engenheiro Guilherme Coelho que havia visitado a experiência uruguaia de cooperativas habitacionais de ajuda mútua no início de 80 traz a proposta para o São Paulo e passa a difundí-la através da exibição de vídeos nas comunidades e ainda pelo trabalho desenvolvido junto à comunidade de Vila Nova Cachoeirinha. Posteriormente, o grupo do Laboratório de Habitação da Faculdade de Belas Artes se envolve no assessoramento das associações comunitárias da zona sul de São Paulo apoiando tecnicamente a viabilização da Urbanização do Recanto da Alegria e, posteriormente, o empreendimento Vila Arco-Íris no Grajaú. E ainda, em São Bernardo do Campo, o arquiteto uruguaio Leonardo Pessina, que tinha acompanhado algumas experiências uruguaias, passa a trabalhar no Brasil com as famílias da Vila Comunitária com base nos mesmos princípios da autogestão, ajuda mútua e solidariedade, com os quais tinha trabalhado no Uruguai junto ao CCU - Centro Cooperativo Uruguaio, órgão que assessorava às cooperativas habitacionais.

${ }^{30}$ Sobre as experiências do Recanto da Alegria e da Vila Arco-Íris consultar BONDUKI (1992), sobre a experiência da Vila Nova Cachoeirinha consultar BARAVELLI (2006). Sobre experiência da Vila Comunitária de São Bernardo consultar GOHN (1991).
} 
A novidade dessas experiências pioneiras estava na presença de profissionais que buscavam romper com os particularismos das ações e demandas dos movimentos ao introduzir, não sem resistência do poder público, novos elementos presentes originalmente na política habitacional uruguaia ${ }^{31}$ : a produção habitacional por cooperativas de usuários que se realizava por meio da autogestão dos recursos aplicados na produção da habitação e do processo de trabalho na execução da obra por ajuda mútua.

Nas experiências descritas por Bonduki (1992), certos desacertos com a máquina pública municipal que não acreditava na proposta e não empregava esforços para viabilizála, trouxeram problemas para a efetivação dos projetos. Apesar da prefeitura ter permitido que o acompanhamento técnico fosse feito por profissionais escolhidos pelos próprios moradores, os recursos destinados a obra eram poucos, e não previam suas contratações. Foi preciso utilizar de subterfúgios, como especificações de janelas, telhados, etc, com valores mais elevados no orçamento geral para garantir a remuneração dos serviços prestados. Determinadas atitudes que geraram grandes desgastes entre as famílias e os técnicos, e ainda, dificuldades para manter as famílias mobilizadas mostravam que a prefeitura não queria abrir mão de gerir os projetos e delegar poder à população.

Apesar dos obstáculos enfrentados, essas experiências foram exceções que se diferenciavam positivamente dos inúmeros mutirões institucionais, promovidos e conduzidos pelo Estado ao longo da década de 80, cujo exemplo mais emblemático foi o da Vila Mutirão em Goiânia (FREITAS, 2007). Buscando neutralizar as ocupações coletivas de terras $^{32}$ concentradas na região Noroeste da cidade, o governador recém eleito Iris Rezende, a partir de relações de compadrinho e cooptação de algumas lideranças promove o mutirão das "mil casas em um dia”. A partir da Vila Mutirão o poder público passou a promover intervenções habitacionais na região Noroeste $^{33}$ do Município, a cerca de $15 \mathrm{~km}$ do centro da cidade, numa perspectiva de segregação social e territorial ${ }^{34}$. A implantação foi feita a

\footnotetext{
${ }^{31}$ Sobre o tema conferir RONCONI (1995) e BARAVELLI (2006), entre outros.

${ }^{32}$ União dos Posseiros de Goiânia, Ligas de Bairro e Assembléia do Povo, apoiadas pela Igreja Católica, com base em entrevista realizada com Vidal Barbosa em 15 de outubro de 2008.

${ }^{33}$ Segundo MOYSÉS (2001), a região Noroeste abriga atualmente cerca de $10 \%$ da população goiâna e mais de 85\% dos moradores possuem renda inferior a cinco salários mínimos, com base no censo de 2000.

${ }^{34} \mathrm{O}$ poder público durante a década de 80 produziu cerca de 10.600 unidades habitacionais nessa região (MOYSÉS, 2001:6).
} 
revelia da legislação ${ }^{35}$ numa zona rural, onde não havia saneamento. Foram utilizadas fossas como solução para o esgoto e, para abastecimento de água, o bombeamento da água do córrego, sem tratamento e distribuída por uma torneira coletiva em cada uma das quadras. As casas de $25 \mathrm{~m}^{2}$ com quarto, sala e cozinha ${ }^{36}$ foram feitas com placas pré-moldadas de cimento de $2,5 \mathrm{~cm}$ e telha de amianto de $6 \mathrm{~mm}$ e apresentaram péssima qualidade e baixo desempenho térmico, já o banheiro externo era um cubículo com vaso sanitário. O único elemento que diferenciava uma das outras eram as cores vermelha, verde, azul e amarela das portas, com o propósito de "procurar dar uma certa identidade" (FREITAS, 2007). Esse empreendimento implantado sem nenhum tipo de equipamento urbano ${ }^{37}$ atendeu famílias com renda inferior a três salários (que pagavam parcelas mensais no valor de cerca de 10\% de salário mínimo). E ainda, colocou a administração peemedebista durante a campanha das "diretas já" em evidência, o que rendeu dividendos políticos ao então governado que pôde indicar um dos idealizadores do Vila Mutirão para ser o Ministro do Desenvolvimento Urbano e Meio Ambiente do Presidente Sarney, em 1985.


Cartilha: “COMO CAIR FORA DO BNH?” (São Bernardo do Campo - SP, 1986).

Enquanto as orientações dos governos se alinhavam às propostas de Turner, expostas anteriormente, em agosto de 1984 foi organizado, por iniciativa dos técnicos que

\footnotetext{
${ }^{35}$ Segundo MOYSÉS “... primeiro criava-se o fato, forçando a sua implantação, depois se tramitava o processo nos órgãos técnicos da Prefeitura..." (2001:09). O governo do estado contrariou as definições da Lei 6.766 de 1979, que permitia a abertura de loteamentos urbanos somente em zonas urbanas, com base na definição municipal.

${ }^{36}$ Sem torneira "... pois para os moradores das invasões esses objetos não tinham serventia e geralmente eram retiradas e vendidas"(!) (FREITAS, 2007:46).

${ }^{37}$ Enquanto as casas foram produzidas em um dia, os primeiros equipamentos foram inaugurados somente depois de um ano.
} 
assessoravam os empreendimentos de mutirão da zona sul de São Paulo e de São Bernardo, o 1 - Encontro de Movimentos de Moradia cujo tema central era Por um cooperativismo de ajuda mútua e autogestão. Lá estavam presentes as associações que vinham participando de processos de mutirão em diferentes bairros da cidade, e mais os representantes da FUCVAM - Federacción Uruguaya de Cooperativas de Vivienda por Ayuda Mútua.

A importância deste encontro está no fato de ter estabelecido a primeira articulação entre associações comunitárias que passaram a construir proposta de uma outra Política Nacional de Habitação. As associações objetivavam o barateamento do custo da produção da habitação social e com isso garantir o acesso das famílias de baixa renda aos programas oficiais de provisão habitacional. Mas, o que diferenciava essa proposta daquela implantada pelos programas alternativos do $\mathrm{BNH}$ ?

Foi proposto que as prestações deveriam ser no máximo de $10 \%$ da renda familiar e as correções das parcelas deveriam ser feitas nos mesmos índices dos reajustes salariais; os prazos de financiamento deveriam ser pré-definidos; as restrições de financiamentos aos trabalhadores desempregados e sem condições de comprovação de renda deveriam ser eliminadas; e para que essas propostas fossem viáveis deveriam ser garantidos recursos do BNH como subsídios às famílias de baixa renda.

Além desses aspectos voltados diretamente à questão habitacional, a proposta elaborada nesse Encontro indicava a alteração da política urbana, visando combater a especulação imobiliária e a retenção das terras vazias. Apontava ainda para novas formas de relações societárias e políticas (SCHERER-WARREN, 1987), ao reconhecer que as cooperativas e associações de moradores poderiam promover a construção de habitações acessando diretamente linhas de financiamento. Por fim, a proposta sinalizava que o controle dos fundos que alimentavam o BNH deveria ser feito também pelos sindicatos dos trabalhadores, associações de mutuários e movimentos populares, afirmando assim, uma redefinição do espaço de cidadania e negando o modelo político centralizador.

Em 1985 realizou-se o 2ํ Encontro de Moradia e nele foi reforçada defesa da opção pela autogestão versus as formas autoritárias nas relações de trabalho. Ficava evidente a influência da experiência uruguaia na formulação das propostas do movimento de moradia 
cujos quatro princípios básicos autogestão, ajuda mútua, solidariedade ${ }^{38}$ e propriedade comum passavam a ser incorporados como bandeira de luta pela recém criada Cooperação dos Movimentos e Associações de Moradia, Ajuda mútua e Autogestão. Princípios presentes, ainda hoje, nas pautas dos movimentos de moradia, em especial da União Nacional por Moradia Popular (UNMP) ${ }^{39}$.

\subsection{A redemocratização do país na (atmo)esfera local}

Os anos de 1987 e 1988 foram marcados pela efervescência das grandes ocupações de terras que vinham ganhando forte repercussão na cidade de São Paulo ${ }^{40}$. Além das CEBs, representantes da Igreja Católica engajados em questões sociais desempenhavam importante papel junto às ações populares em torno da luta pela moradia ${ }^{41}$, especialmente na Zona Lesta da cidade, onde foram estimuladores da formação da União de Movimentos de Moradia de São Paulo (UMM-SP), que se caracterizava por ser um movimento de massa e de ação coletiva mediada pela ação direta e pela ação negociada (PAZ, 1996).

Nesta mesma época, ao longo do processo de elaboração e promulgação da Constituição de 1988 o Movimento Nacional pela Reforma Urbana reuniu diversas entidades em torno da discussão e politização da questão urbana.

\footnotetext{
${ }^{38}$ Nesta época, no mutirão do colégio Adventista, zona sul de São Paulo, foi criado o "Fundo de Solidariedade para tentar solucionar o problema de pessoas que ficam desempregadas ou têm um imprevisto fora do seu orçamento" em entrevista concedida por Modesto Azevedo e Vando Elídio à Revista Proposta no35 (1987:1021).

${ }^{39}$ O XI Encontro Nacional da União em junho de 2008, teve entre as pautas debatidas a questão da propriedade coletiva que apresenta ainda hoje impedimentos jurídicos para se concretizar.

${ }^{40}$ A partir de 1987 ocorreram grandes ocupações na Zona Leste. Somente no mês de fevereiro, cerca de 32 mil famílias ocuparam 238 áreas na região, como o caso da área da Garagem de São Miguel. Em 1988 ocorrem as ocupações da Fazenda da Juta e do Jardim Colorado, descritas por Felipe (1997). Antes disso, tinham ocorrido as ocupações da Fazenda Itupú e da propriedade da Rádio Record no Parque Europa, ambos na zona sul de São Paulo em 1981. Seguidas pelas ocupações do terreno no Grajaú e do Instituto Rural em 1983, apresentadas pela Revista Proposta no 35 (1987) e por Bonduki (1992). E das ocupações do terreno da Santa Casa de Misericórdia pelos "filhos da terra" na zona norte entre 1982 e 1983, relatada por Gonh (1991).

${ }^{41}$ Segundo FELIPE o Plano Quadrienal de 1987 - 1991 da Arquidiocese de São Paulo definiu claramente qual o papel a ser desempenhado pela Igreja junto aos "Sem-Terra": "a) apoiar a organização e as formas de luta dos sem terra, visando a conquista do chão para morar através de: formação de grupos nas áreas e setores; mutirão como forma de construção com financiamento de material e apoio técnico; ocupações, caravanas, manifestações; possibilitar uma maior formação (econômica-política-teológica) relacionada à questão da moradia."(1997:30).
} 
O processo de elaboração da constituinte, segundo Moroni e Ciconello (2005), foi um momento de consagração de direitos, avanços em relação ao modelo democrático, criação de espaços de participação direta e indireta. O movimento social ${ }^{42}$ se colocou como um importante agente no debate sobre a (re)democratização do Estado brasileiro, e com o propósito de tornar o Estado efetivamente público, enfatizou questões no sentido de garantir e efetivar os direitos civis, políticos, sociais, econômicos e culturais, e assegurar a participação popular efetiva nas políticas públicas e nas decisões de interesse público.

O envolvimento nesse processo, que resultou na elaboração da Emenda Popular sobre a Reforma Urbana, permitiu aos movimentos populares apropriação de novos conceitos sobre a cidade, sobre a gestão participativa e demais mecanismos que poderiam fortalecer sua organização e ação.

Associado ao processo de luta pela democracia se iniciou o processo de descentralização das políticas públicas no Brasil. A partir de novas perspectivas, com base nas bandeiras de luta do movimento de Reforma Urbana e das ações conjuntas dos movimentos de moradia e assessores técnicos, diversas propostas foram formuladas e implementadas em gestões municipais ${ }^{43}$ e estaduais, efetivando na prática os anseios sociais construídos ao longo dos anos de repressão e excessiva centralização no governo federal. A gestão municipal de São Paulo de 1989 a 1992 foi o caso paradigmático da concretização de certas propostas.

Após os quatro anos da prefeitura de Jânio Quadros (1986-1988) representada, salvo raras exceções, pelos retrocessos das propostas habitacionais e autoritarismo em relação às ações do movimento popular, em 1989 o tratamento das questões urbana e habitacional ganha viés mais progressista a partir da eleição da Luiza Erundina para o exercício da gestão municipal de São Paulo ${ }^{44}$. A composição do corpo técnico da Secretaria Municipal de Habitação foi preenchida por profissionais que reconheciam a cidade real, encabeçavam a

\footnotetext{
42 Tratado aqui como amplo campo de atuação progressista que tem como agenda política a construção do Estado democrático e social composto, dentre outros, pelos movimentos de reforma urbana.

${ }^{43}$ As experiências de gestões públicas como a de Recife, Diadema, Santos e posteriormente, Porto Alegre, Belo Horizonte, Santo André, entre outras.

44 Sobre a experiência municipal de São Paulo (1989-1992) consultar BONDUKI (1996) e BONDUKI, Nabil. Habitar São Paulo: reflexões sobre a gestão urbana. São Paulo: Estação liberdade, 2000 (não citado na bibliografia), entre outros.
} 
luta pela reforma urbana no País e que vinham atuando junto aos movimentos populares nos mutirões experimentais dos anos anteriores.

Em relação às necessidades habitacionais adotou-se como diretriz a diversidade de intervenções conforme as especificidades de cada problema, como a urbanização e regularização fundiária de favelas, verticalização de favelas, melhorias habitacionais e atuação em cortiços, produção de novas moradias por linhas diversas, meios para garantir acesso à terra urbanizada e à segurança da posse da terra.

Além da aplicação dessas novas diretrizes à política habitacional, a prefeitura reconheceu a importância da democratização e transparência da gestão pública e buscou atribuir à população historicamente colocada à margem da cidade e da sociedade, o papel de sujeitos políticos com poder de decisão, a partir da abertura do diálogo e por meio de novos mecanismos de participação.

"O Movimento popular portador de uma grande expectativa gerada com a vitória de uma administração democrática e popular, aumentava a pressão e exigia uma resposta concreta" (RONCONI, 1995:21).

"... Então, a gente falava que queria que o Estado tivesse terra, a gente queria um financiamento diferente daquele da $C O H A B$, a gente queria o mutirão... Mas não tinha isso muito organizado, formatado". (Evaniza Rodrigues, 27.02.2008)

"A proposta da autogestão, ainda em 1989, é assumida muito parcialmente. Os movimentos não a tinham como palavra de ordem. O que colocavam, sim, era a questão do mutirão e a questão da terra. A grande reivindicação da União dos Movimentos de Moradia era: "mil lotes em cada região" (BONDUKI, apud SILVA, 1994:09).

Os movimentos de moradia queriam respostas rápidas, e sem poupar a gestão progressista faziam pressão, com atos e acampamentos "atuando (...) como agentes impulsionadores e legitimadores do espaço que se abria na HABI-SEHAB com o FUNACOM" (FELIPE, 1997:42).

A proposta do Programa Funaps-Comunitário ${ }^{45}$ não existia previamente. Segundo Felipe (1997), não foi possível identificar no programa de governo divulgado durante a

\footnotetext{
${ }^{45}$ Sobre assunto ver RONCONI (1995), FASE-SP. Mutirões autogestionários: levantamento de obras 1989-1995. São Paulo: FASE-SP, s/d (não citado na bibliografia); AMARAL (2001), FELIPE (1997) e CARVALHO (2004).
} 
campanha eleitoral da então prefeita, algo similar a proposta de produção habitacional por meio da autogestão ${ }^{46}$. Esta foi incorporada gradualmente enquanto linha de ação da Superintendência de Habitação Popular (HABI), com certa resistência dentro da própria Secretaria de Habitação, inicialmente sugerindo apenas o caráter experimental à proposta.

“... no Plano de Ação Imediata que fizemos no começo de 1989 previa-se a distribuição de 15 mil lotes, dos quais 3 mil para a construção de casas e mil para processos alternativos experimentais baseados em cooperativas de Autogestão." (BONDUKI apud SILVIA, 1994:64).

Segundo Bonduki, as críticas apontadas no período se relacionavam com "... 0 receio de perder o poder no âmbito do governo", em relação "... a questão do sobretrabalho ou se dirigiam ao fato que o Estado estava abrindo mão de suas responsabilidades" e ainda àquelas que "consideravam as práticas de autogestão como sistemas arcaicos, atrasados e inadequados para enfrentar o problema da habitação" (BONDUKI apud SILVIA, 1994:61).

A presença de profissionais na $\mathrm{HABI}$ que haviam participado diretamente como assessores técnicos das associações, nas primeiras iniciativas de produção habitacional por mutirão autogerido em São Paulo, São Bernardo e Diadema, possibilitou a efetivação da proposta.

Pode-se dizer que o programa tornou o carro chefe entre as ações geridas pela HABI, ao propiciar com certa agilidade ${ }^{47}$ em três anos e meio de funcionamento 93 convênios para a construção de 12.351 unidades habitacionais produzidas por mutirão autogerido (RONCONI, 1995), no modelo de programa público de habitação, dentro das limitações legais brasileiras, que mais se aproximou da proposta uruguaia de produção habitacional por cooperativas de ajuda mútua.

Por meio de convênio firmado entre a Prefeitura Municipal de São Paulo e a associação de famílias era estabelecida uma parceria. Coube à Prefeitura definir as regras do

\footnotetext{
${ }^{46}$ Após a surpreendente vitória de Luiz Erundina, a formação da equipe foi feita às pressas, e muitas propostas que foram incorporadas à gestão municipal não compunham o programa de governo inicial.

${ }^{47}$ Nabil Bonduki em conversa realizada em 06 de junho de 2008, relatou que a princípio os empreendimentos do FUNACOM não passavam por aprovação de projeto, e não dependiam de licitação como os empreendimentos da $\mathrm{COHAB}$, o que trouxe agilidade e fluidez ao programa (vale lembrar que a Lei Federal no8.666 de 1993 ainda não existia) entretanto, gerou uma série de problemas posteriores, como a irregularidade fundiária.
} 
programa e financiar os empreendimentos com recursos do Fundo de Atendimento à População Moradora em Habitação Subnormal (FUNAPS).
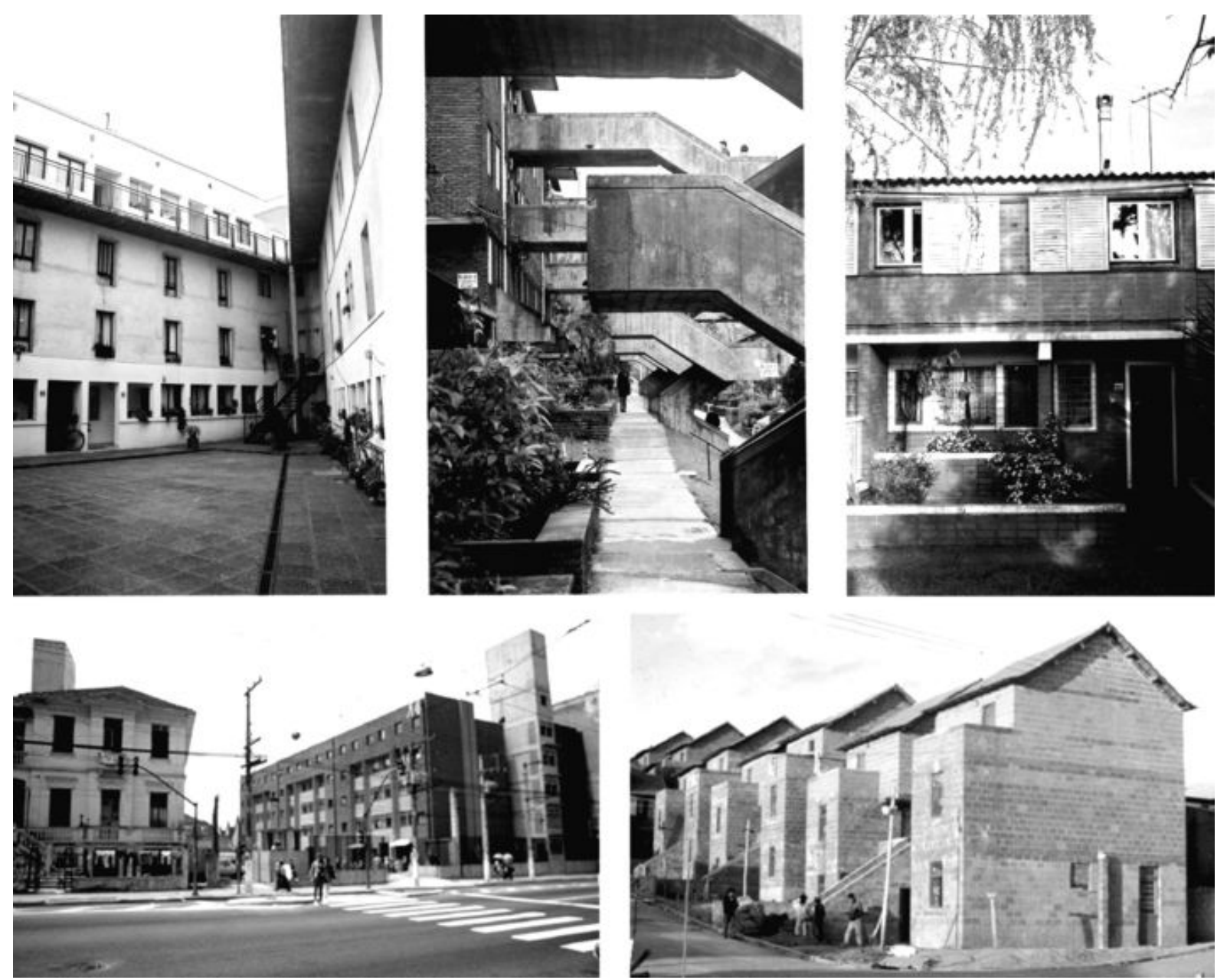

Acima: Cooperativas de habitação vinculadas à FUCVAM, Uruguai fonte: arquivo pessoal (2001)

Em baixo: Mutirões autogeridos, FUNAPS-Comunitário, São Paulo (Celso Garcia e São Francisco - setor 5) fonte: (BONDUKI, 2000:84-97).

O FUNAPS ${ }^{48}$ foi criado em 1979 para viabilizar à PMSP uma atuação independente do Sistema Financeiro da Habitação, e seus recursos poderiam ser destinados, a fundo perdido, para o atendimento de famílias até quatro salários mínimos moradoras de habitações precárias. Nas gestões municipais seguintes (Covas e Jânio) os recursos foram aplicados à critério do gestor em intervenções de situação de risco, para aquisição de terra, para mutirões e ações de desfavelamento. Na gestão Erundina, mesmo com alguns

\footnotetext{
${ }^{48}$ O fato do Fundo não possuir uma personalidade jurídica criava uma série de impedimentos para garantir amplo funcionamento da nova política proposta. Apresentou-se a Câmara uma proposta, não aprovada, que transformaria o FUNAPS em uma fundação ligada à Administração.
} 
impedimentos jurídicos, o recursos do FUNAPS foram destinados para viabilizar as ações da $\mathrm{HABI}$, entre elas o programa de provisão habitacional por mutirão autogerido: FUNAPSComunitário (FUNACOM), as intervenções em área de risco em favela e a urbanização de favela comunitária (URBANCOM) ${ }^{49}$.

A Assessoria Técnica contratada diretamente pela Associação desempenhava importante papel, sendo responsável pela elaboração do projeto conjuntamente ao grupo de famílias respeitando as especificidades do local onde seriam implantados, e pelo processo de acompanhamento de execução da obra a ser realizada por mutirão.

A associação, formada por todas as famílias beneficiárias do Programa, comandava os processos construtivos, administrativos, financeiros, sempre com aporte técnico, jurídico e contábil das assessorias. Ou seja, a comunidade com autonomia fazia todo o processo de gestão da aplicação dos recursos públicos destinados à produção das moradias, o processo de trabalho na execução das obras, e ainda se responsabilizava pelas prestações de contas à prefeitura.

A possibilidade de participar desse rico exercício coletivo de tomada de decisões sobre rumos do grupo e da própria vida, de responder as suas próprias necessidades e desejos e aprender a respeitar as necessidades e desejos dos outros, permitiu ganhos significativos nos custos finais das obras, na maior qualidade das casas e conjuntos produzidos, e ainda na formação cidadã de cada um dos envolvidos.

A experiência vivida pelos movimentos de moradia de São Paulo proporcionou a ampliação dos grupos de base, o fortalecimento da organização e amadurecimento de suas propostas. Permitiu ainda, que a ação do movimento extrapolasse o âmbito local, alcançando a proposição de mudanças significativas no âmbito das políticas nacionais ${ }^{50}$. Estava desenhado um novo padrão de cidadania buscando influir na vida política, que neste momento, se alargava (DAGNINO, 1999).

\footnotetext{
${ }^{49}$ Os mesmos princípios autogestionários foram utilizados nas intervenções em Cortiços, casos do Mutirão Celso Garcia e Madre de Deus, e também em alguns processos de urbanizações de favela, conforme Bonduki em conversa realizada em 06 de junho de 2008.

${ }^{50} \mathrm{O}$ retrato do fortalecimento e amadurecimento da atuação dos movimentos de moradia de São Paulo, especialmente da UMM-SP, foi a negociação e conquista com o Governo do Estado de São Paulo da criação do Programa de Mutirão-UMM, e posteriormente, do Programa Paulista de Mutirão que proporcionaram um novo fôlego ao movimento após a eleição de Paulo Maluf para a Prefeitura de São Paulo e suspensão do Programa FUNAPS-Comunitário. Sobre o Assunto ver Royer (2002).
} 
“... com a tremenda vitória dessa realização [mutirão autogerido], o movimento fez uma avaliação política muito correta: de que estava ali lançada uma semente, mas que os recursos municipais eram absolutamente insuficientes para poder dar a esse trabalho o caráter de massa..." (CONFORTO apud PAZ, 1996:108).

\subsection{A redemocratização do país na (atmo)esfera federal}

Apesar das crescentes reivindicações populares, do fortalecimento da organização da sociedade civil e da efervescência social e política presentes nas práticas cotidianas dos centros urbanos, em meados da década de 80, na esfera federal o processo de redemocratização política do país parece ter acontecido de forma descolada deste burburinho, e foi marcado por uma transição negociada e sem rupturas em relação às diretrizes políticas e do status quo. A crise econômica, que se agravou ao longo da "década perdida", tornou mais agudo o quadro de desigualdade social presente na sociedade brasileira, em 1989 os $10 \%$ mais ricos detinham $51,7 \%$ da renda nacional, enquanto os $50 \%$ mais pobres apenas $10,5 \%{ }^{51}$.

Perpetuou-se, em linhas gerais, a manutenção dos interesses das classes dominantes e, conforme apontado por Fernandes $(1986)^{52}$, realizou-se a transposição da dimensão patrimonialista e clientelista presentes no regime autoritário para o período democrático.

Em 1986, o BNH foi abruptamente extinto em meio a intensas discussões a respeito das medidas mais adequadas para realizar as reformas do Sistema Financeiro de Habitação. Ao longo da Nova República a agenda reformista na política habitacional, implantada ainda pelo regime militar, foi mantida com o objetivo de driblar as crescentes reivindicações populares por políticas de caráter social e para enfrentar o quadro de crise do funcionamento do SFH.

Segundo Santos (1999), as atribuições do BNH foram distribuídas entre o Banco Central que ficou responsável pela normatização e fiscalização do SBPE; a Caixa Econômica Federal (vinculada ao Ministério da Fazenda) que atuou como gestora do FGTS e agente

\footnotetext{
${ }^{51}$ CACCIAMALLI, 2002 com base IBGE/PNAD diversos anos.

${ }^{52}$ FERNANDES, Florestan. Nova República? Rio de Janeiro: Jorge Zahar Editor, 3 ed., 1986 apud ROYER (2002).
} 
financeira e operadora do SFH; o Ministério "urbano" (à época) ${ }^{53}$ que ficou responsável formalmente pela política habitacional - em especial pela gestão dos programas tradicionais; e por fim, a Secretaria Especial de Ação Comunitária responsável pelos programas alternativos ${ }^{54}$.

Inicialmente avaliou-se, que a agenda do desenvolvimento urbano e da política habitacional seria privilegiada em função da existência de um Ministério que cuidaria exclusivamente do assunto. Porém, no decorrer dos anos em função do troca-troca ministerial responsável por tal atribuição, deflagrou-se um arranjo institucional frágil e desarticulado sugerindo, e posteriormente, confirmando a inexistência de uma proposta concreta que viesse substituir a política anterior.

A partir deste momento a CEF passou a exercer papel central dentro da política nacional da habitação e ter autonomia suficiente para dar a linha mestra da ação no setor (AZEVEDO, 2007). As características de banco comercial que busca equilíbrio financeiro e garantias de retorno do capital investido presentes na CEF, trouxeram efeitos significativos aos programas do SFH, acentuando a incompatibilidade com as diretrizes das políticas sociais, que necessitavam de altos subsídios e de maior dinamização na operação do crédito para viabilizar o atendimento das faixas de menor renda, já percebida nos tempos do BNH.

Após o Plano Cruzado em 1986, a CEF criou medidas restringindo ainda mais o acesso a créditos principalmente às $\mathrm{COHABs,} \mathrm{sob} \mathrm{a} \mathrm{justificativa} \mathrm{de} \mathrm{conter} \mathrm{as} \mathrm{dívidas} \mathrm{do} \mathrm{setor} \mathrm{público}$ e em função do alinhamento às diretrizes dos subseqüentes planos de estabilização econômica. Em função dessas restrições, os poucos financiamentos concedidos durante este governo para a produção habitacional por meio dos recursos do SFH foram destinados a responsabilidade da iniciativa privada.

No contexto mais crítico da crise habitacional, pela primeira vez os recursos do Orçamento Geral da União (OGU) foram aplicados a uma ação habitacional. O Programa Nacional de Mutirões da SEAC foi a única alternativa de atendimento a famílias com renda

\footnotetext{
${ }^{53}$ Em 1985, a política habitacional estava vinculada ao Ministério de Desenvolvimento Urbano (MDU) que se transformou em Ministério da Habitação, Desenvolvimento Urbano e Meio Ambiente (MHU), depois passou a ser Ministério de Habitação e Bem-estar Social (MHBES) e, por fim, voltou ao Ministério do Interior, em 1989.

${ }^{54}$ Ao longo do governo Sarney, a SEAC - Secretaria Especial de Ação Comunitária esteve vinculada inicialmente ao Ministério do Planejamento, à Casa Civil da Presidência, depois passou a fazer parte do Ministério da Habitação e Bem-Estar Social, do Ministério da Previdência e, por fim, vinculou-se ao Ministério do Interior.
} 
inferior a três salários mínimos, realizado por meio de convênios entre a SEAC, prefeituras ou órgãos estaduais, e as associações comunitárias formadas pelos participantes do projeto, nos moldes mais tradicionais dos processos de produção habitacional por mutirão (SANTOS, 1999). Vale lembrar que pouco antes, o mutirão "das mil casas em um dia" do Governador Iris Rezende ganhou grande repercussão pelo país e que o Ministério do Desenvolvimento Urbano e Meio Ambiente estava sob comando de um dos formuladores dessa proposta.

Enquanto a previsão de investimentos às ações da SEAC em um período de menos de dois anos era financiar 550 mil unidades habitacionais, as COHABs financiaram pelos programas tradicionais cerca de 150 mil unidades ${ }^{55}$. Apesar dos números sugerirem um aparente desempenho positivo do Programa de Mutirões, segundo AZEVEDO (2007), muitos desses projetos não foram construídos em decorrência da alta inflação (que não interferia exclusivamente no desempenho deste programa), somados aos baixos valores unitários de financiamento e sua má gestão. Sem critérios claros de priorização dos investimentos, abriram-se brechas para reforçar práticas clientelistas, e para que ocorresse uma distribuição desigual de recursos dos programas em resposta à interesses políticos. Ao final do governo Sarney, dada à fragilidade institucional do período, o Programa Nacional de Mutirões foi interrompido.

\subsection{Fundo Nacional de Moradia Popular.}

“... a União se fortalece com o governo Erundina, e parte para a proposta do Fundo Nacional de Moradia Popular...". (Leonardo Pessina, 19.03.2008)

"Eu falo o seguinte, que o conceito da autogestão é que construiu o Fundo Nacional (Moradia Popular). A idéia era fazer uma política aos moldes do programa de autogestão" (Evaniza Rodrigues, 27.02.2008)

A relação dos movimentos populares com o governo federal sempre foi mais difícil e rarefeita se comparada com o trato estabelecido com os governos municipais e estaduais. Não somente pela distância concreta da capital do país em relação aos principais e mais

\footnotetext{
${ }^{55}$ Com base em SEAC (1988) e CEF (2000) respectivamente, citados por AZEVEDO (2007).
} 
populosos centros urbanos, mas pela distância simbólica do fechamento do Estado ao diálogo com a sociedade, ainda como resquícios dos tempos autoritários.

Ao final da década de 80 estava deflagrada a maior crise do sistema habitacional do país. Entretanto, não adiantava apenas pressionar o poder local, que vinha empreendendo soluções baseadas nos seus próprios e insuficientes recursos orçamentários depois de anos de ação centralizada na esfera federal, considerando que a raiz do problema estava em outro lugar.

A retenção especulativa da terra foi tomada como um dos principais gargalos da crise habitacional, no momento em que ainda não havia nenhum estatuto jurídico que definia alguma medida que coibisse tal prática (MARICATO, 1988). Além da questão da terra, o SFH principal fonte de recursos destinados às intervenções habitacionais em período de forte recessão encontrava-se em falência. Os saques aumentavam (tanto do FGTS, quanto das poupanças) e as contribuições diminuíam em função do aumento do desemprego e subemprego, e pela gigantesca inadimplência dos mutuários em decorrência dos reajustes feitos sem compatibilidade com as variações salariais. O frágil arranjo institucional fruto da descentralização federativa mal implantada, era retrato da ausência de diretrizes nacionais, por meio de uma política pública, para o tratamento da questão habitacional que viesse substituir a extinta proposta do BNH (ARRETCH, 1996).

Todos esses fatores incentivaram a articulação dos movimentos de luta de moradia do país e a organização das "caravanas da moradia" à Brasília, que funcionam ainda hoje como fator de articulação e aglutinador dos movimentos de moradia e reforma urbana do país, e como instrumentos de denúncia, reivindicação e proposição.

Em 1988 a UMM-SP organizou a primeira caravana, que reuniu cerca de 300 pessoas vindas de São Paulo e mais um pequeno grupo de Pernambuco para apresentar suas reivindicações pela liberação de recursos para produção de moradias, elaboração de política pública de habitação e, denunciar a miséria e a enorme carência habitacional (PAZ, 1996). O mérito dessa caravana ainda no governo Sarney foi à abertura de diálogo com a CEF, que se compromete a implantar um programa que atendesse as exigências do movimento ${ }^{56}$.

\footnotetext{
${ }^{56} \mathrm{O}$ fato do diálogo ter sido estabelecido entre movimento e CEF, e não com o Ministério responsável pelo assunto, reforçou o dado apresentado anteriormente do frágil e desarticulado arranjo institucional, e o peso da CEF nas definições das ações públicas voltadas ao setor habitacional.
} 
No ano seguinte, em 1989, em outra caravana à Brasília, os movimentos de moradia $^{57}$ denunciaram a má administração pelas autoridades dos recursos do FGTS, e cobraram maior controle e transparência no uso desses recursos ${ }^{58}$.

"... é questionado o Sistema Financeiro de Habitação, mas ainda querendo que o tal do FGTS financiasse projetos de habitação para baixa renda (...) Enfim, esse negócio não serve pra gente, mas não tínhamos nada para pôr no lugar." (Evaniza Rodrigues, 27.02.2008).

No mesmo período, cobrou-se da CEF o compromisso da implementação do programa assumido no ano anterior:

"A gente teve uma reunião com o presidente da CEF naquele momento. Ele topa fazer um projeto piloto e, a gente com a Claudia Serpa, a gente bola o PROHAPComunidade que não chegou a ser uma linha de financiamento, nem um programa, mas constrói (sic) três propostas: uma em São Bernardo, uma em Diadema e outra na Zona Leste. Mas na Zona Leste não se viabiliza por problema na terra, e acabam sendo duas" (Leonardo Pessina, 19.03.2008).

Ainda no governo Sarney, o PROHAP-Comunidade em caráter piloto financiou diretamente para as associações, com recursos do FGTS, dois projetos de mutirão autogerido. Um para em São Bernardo do Campo, na Vila Industrial, cujo projeto de produção de 50 sobrados e acompanhamento de obra foi realizado pela assessoria técnica CAAP, e mais 100 unidades habitacionais distribuídas em casas sobrepostas e apartamentos no "Buraco do Cazuza", cujo projeto foi desenvolvido pela Prefeitura Municipal de Diadema e o acompanhamento da obra foi realizado pela Assessoria Técnica Usina.

"Aí, foi super elogiado, teve uma avaliação positivíssima da CEF, mas não deu em nada... E na mesma linha, quando assume o Collor, uma cara que tinha trabalhado comigo na CDHU, virou Diretor Nacional de Habitação, e numa caravana também falamos com ele. Mostramos um projeto em Santo André. O cara se encanta com o projeto e excepcionaliza um PAIH - Programa de Ação Imediata Habitacional" (Leonardo Pessina, 19.03.2008).

\footnotetext{
${ }^{57}$ Segundo Vidal Barbosa, em entrevista realizada em 15 de outubro de2008, o Movimento Nacional de Luta por Moradia nasceu em 1989, com sede em Goiânia e passou a organizar com Padre Ticão a caravana à Brasília desse ano junto com os movimentos de Minas Gerais e Paraná.

${ }^{58}$ Não se sabe o quanto essa ação influenciou na tomada de decisão, sabe-se apenas que neste mesmo ano foi criado o Conselho Curador do FGTS.
} 
Entre 1987 e 1990, em decorrência dos fatores expostos anteriormente, poucos foram os contratos feitos com recursos do FGTS seguindo uma tendência iniciada nos anos 80 de retração de investimentos feitos pelo poder público em habitação ${ }^{59}$. Porém, entre 1990 e 1991, ocorre o retorno expressivo de suas operações, respondendo a uma orientação neoliberal que introduziu novas formulações das políticas sob a primazia de Mercado sobre Estado (DRAIBE, 1993 apud PAZ, 1996). Foi criado o Programa de Ação Imediata para Habitação, o PAIH ${ }^{60}$, operado a partir do PRODURB-Habitação (Programa de Urbanização de Áreas e Regularização Fundiária), do PROHAP (Programa de Habitação Popular) o principal programa para produção de novas unidades em parcerias com setores privados e COHABs, e do PEP (Plano Empresário Popular).

Apesar dos programas apresentarem diferentes modalidades de intervenção 94,76\% dos contratos realizados até 1991 foi destinado à produção de unidades novas, sendo que a maior parte destes foi executada pela iniciativa privada, totalmente financiada com recursos do FGTS, a juros reais entre 3,5\%a.a. e 5,5\%a.a. para o beneficiário final ${ }^{61}$.

Entre 1990 e 1991, a partir de critérios políticos ${ }^{62}$, foi contratado o total de 526 mil unidades habitacionais superando a capacidade de financiamento do FGTS (SANTOS, 1999). Tal fato além de comprometer os orçamentos dos anos seguintes, inviabilizando novas operações via FGTS, levou à paralisação de inúmeras obras e à problemas de comercialização que se estenderam ao longo dos anos. Dentre esses processos estava o projeto de Santo André:

“... E acabam sendo 202 unidades habitacionais, acho que são 40 térreas e 162 sobrados. Eram três tipologias isso que encantou o diretor, pois eram três tipologias diferentes... Isso aí se arrasta ao longo do tempo e termina em 1997, com a presença do Ministro do Planejamento do FHC, o Antônio Kandir..." (Leonardo Pessina, 19.03.2008).

\footnotetext{
${ }^{59}$ As Tabelas 2 (p.65) e 3 (p.66) que mostram a evolução ao longo dos anos dos financiamentos concedidos pelo SFH e o número de unidades habitacionais produzidas, ilustram este momento de forte regressão do governo Sarney, seguido pelo súbito aumento dos investimentos na habitação por meio do SFH, no governo Collor.

${ }^{60}$ Resolução no 18 de 1990 do Conselho Curador do FGTS.

${ }^{61}$ BRASIL. Ministério da Ação Social/ SNH/ DAP. Relatório Gerencial de Acompanhamento e Controle dos Programas Habitacionais PAIH/ PEP/ PROHAP/ Cooperativas. Brasília: MAS, 1992 apud Royer (2002).

62 Entrevista realizada em 02 de abril de 2008 com Henriqueta Alves (representante da CBIC, integrante do CCFGTS na década de 90 e assessora técnica da FAMEMG).
} 
A quarta caravana que reuniu cerca de cinco mil pessoas chegou à Brasília em 19 de novembro de 1991, ainda no governo Collor, em decorrência de uma grande articulação entre movimentos populares e entidades, e foi marcada pela entrega do primeiro Projeto de Lei de Iniciativa Popular ao Congresso Nacional. Por cerca de um ano ocorreu o processo de articulação e elaboração do projeto de Lei para a criação do Fundo Nacional de Moradia Popular, seguido pelo recolhimento de assinaturas suficientes para referendar uma proposta alternativa à (ou ausência de) política oficial de habitação de interesse do povo brasileiro ${ }^{63}$.

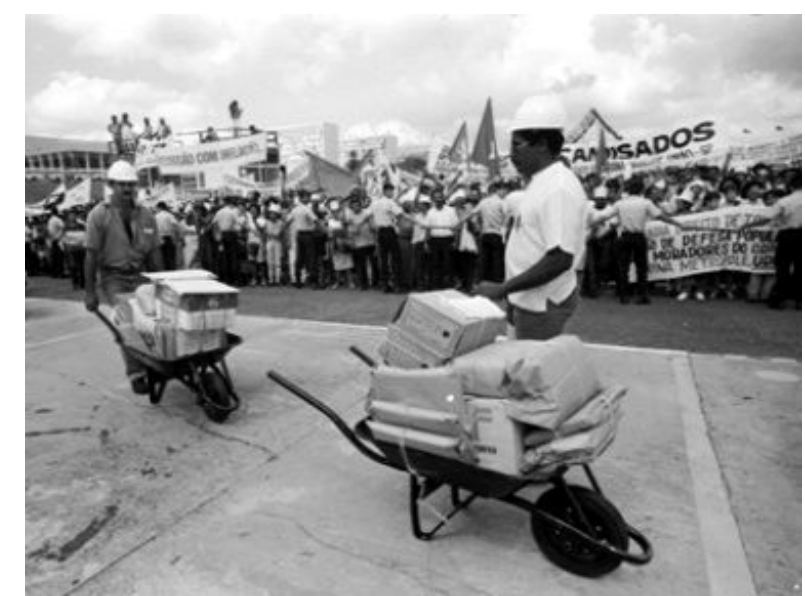

Entrega das assinaturas do Projeto de Lei do FNMP ao Congresso Nacional, novembro de 1991. fonte: Douglas Mansur.

O Projeto de Lei de Iniciativa Popular tinha como ponto central a criação de um Fundo Nacional de Moradia Popular e de seu Conselho que deveria ser representativo e deliberativo com a responsabilidade de definir e fiscalizar a aplicação dos recursos deste fundo. Até então todas as discussões a respeito da utilização dos recursos federais giravam em torno do SFH (recursos do FGTS e SBPE) e foi a primeira vez que se propôs organizar os recursos destinados à habitação de outra forma, a partir de composições de recursos onerosos e não-onerosos de fontes distintas e da vinculação de orçamento público. Outros princípios fundamentais presentes no projeto de lei e que geraram muito debate até a formulação da proposta final entregue ao Congresso, diziam respeito à prioridade de atendimento à população de baixa renda; à necessária diversidade de programas e projetos habitacionais; ao reconhecimento das associações de moradores e cooperativas

\footnotetext{
${ }^{63}$ Quase um milhão de assinaturas, com base em Paz (1996).
} 
habitacionais como agentes promotores dos programas; e ainda à definição de recursos específicos destinados a uma política de subsídio para as famílias de menor renda.

Pode-se identificar que parte desses princípios estava presente no documento resultante dos debates do primeiro Encontro de Moradia ocorrido em São Paulo ainda em 1984 e certamente influenciaram a elaboração da proposta. Além do resgate desses princípios, a experiência do Sistema Único de Saúde e a história do movimento de saúde, conforme apontado por Paz (1996) foram importantes inspirações para o movimento de moradia na formulação de sua proposta, tanto pelo formato descentralizado entre as três esferas governamentais, quanto no propósito de universalização do acesso a um direito básico.

E ainda, pode-se afirmar que a experiência do FUNAPS-Comunitário serviu como importante referência, por um lodo, pela maneira como o programa havia sido formatado com base em um fundo composto por orçamento público, que pressupõe certa continuidade da ação púbica e permite aplicação de subsídios, e por outro, por ter concretizado a idéia de uma política pública que atendesse de maneira digna às necessidades do segmento da população mais pobre, sempre posta à margem dos programas oficiais, a partir de princípios autogestionários que propiciavam o fortalecimento da autonomia e da cidadania das famílias envolvidas.

“... o movimento parte com essa bandeira (FNMP), calcada na realidade comprovada de que se poderia realizar, para vender para todo país essa proposta..." (CONFORTO apud PAZ, 1996:108).

A riqueza desse processo estava no fato de que o movimento popular, principal fomentador e animador da proposta, criou uma rede de articulação de entidades sociais de representação nacional ${ }^{64}$ e movimentos locais dos mais diferentes estados que se envolveram no debate, no processo de coleta de assinaturas ${ }^{65}$ e nesse momento, estavam influindo diretamente na vida política e na formulação da política pública nacional.

\footnotetext{
${ }^{64}$ Entre elas a CONAM, a Federação de Moradores do Rio Janeiro - FAMERJ, a ANSUR, a Coordenação Nacional dos Movimentos de Moradia e a Pró-Central de Movimentos Populares.

6518 estados participaram do processo de coleta: SP, RJ, PR, SC, RS, MS, MT, RO, MA, PA, PI, PB, PE, CE, BA, MG, ES, GO e DF alcançando cerca de 850 mil assinaturas.
} 
Todo este processo à época foi menos importante para a publicização da questão das carências habitacionais e da ausência de uma política nacional de habitação, pois a atenção da grande imprensa se voltou para o fato de ter sido primeiro Projeto de Lei de Iniciativa Popular entregue ao Congresso após a aprovação da Constituição de 1988 (PAZ, 1996:127). Era a vida política, de fato alargada para fora das paredes do Congresso Nacional.

No final de 1992, já no governo Itamar Franco, depois de um ano da entrega do PL ao Congresso ocorre a primeira reunião do Fórum Nacional de Habitação, que funcionou até 1994, composto por representantes do setor público (representado pelo Fórum de Secretários Estaduais de Habitação), do setor da indústria da construção civil e do setor popular organizado. Foi a primeira vez que diferentes setores se dispuseram a debater idéias e interesses tão divergentes e a construir um objetivo comum entre os aspectos envolvidos no financiamento, na produção e no uso da habitação em torno da proposta do Conselho e Fundo, e ainda impedir a exclusiva responsabilidade da formulação da política de habitação apenas a um único órgão federal (AZEVEDO, 2007).

Pode-se dizer que toda essa movimentação no Congresso Nacional em torno da pauta da habitação, em especial do debate sobre os mecanismos de controle social, e conseqüentemente, maior transparência e participação da sociedade civil na gestão dos programas habitacionais, influenciaram na definição de algumas diretrizes do então governo Itamar Franco. A abertura dos canais de diálogo com a sociedade trouxe grande impacto simbólico, após um período de fortes escândalos de corrupção que resultaram no impeachment do presidente anterior.

Apesar deste importante avanço institucional foram poucas as concretizações efetivas em relação ao setor em função da crise estrutural do SFH, pela qual nada foi feito e que se estendia desde os anos do regime militar. Os investimentos em habitação neste período ficaram muito aquém do que se espera em função da indisponibilidade de uso dos recursos do FGTS e da retenção de gastos da União pelo contingenciamento de recursos imposto pelo Plano Real. 
Tabela 2

Valores referentes aos financiamentos habitacionais concedidos pelo SFH (1964-2006)

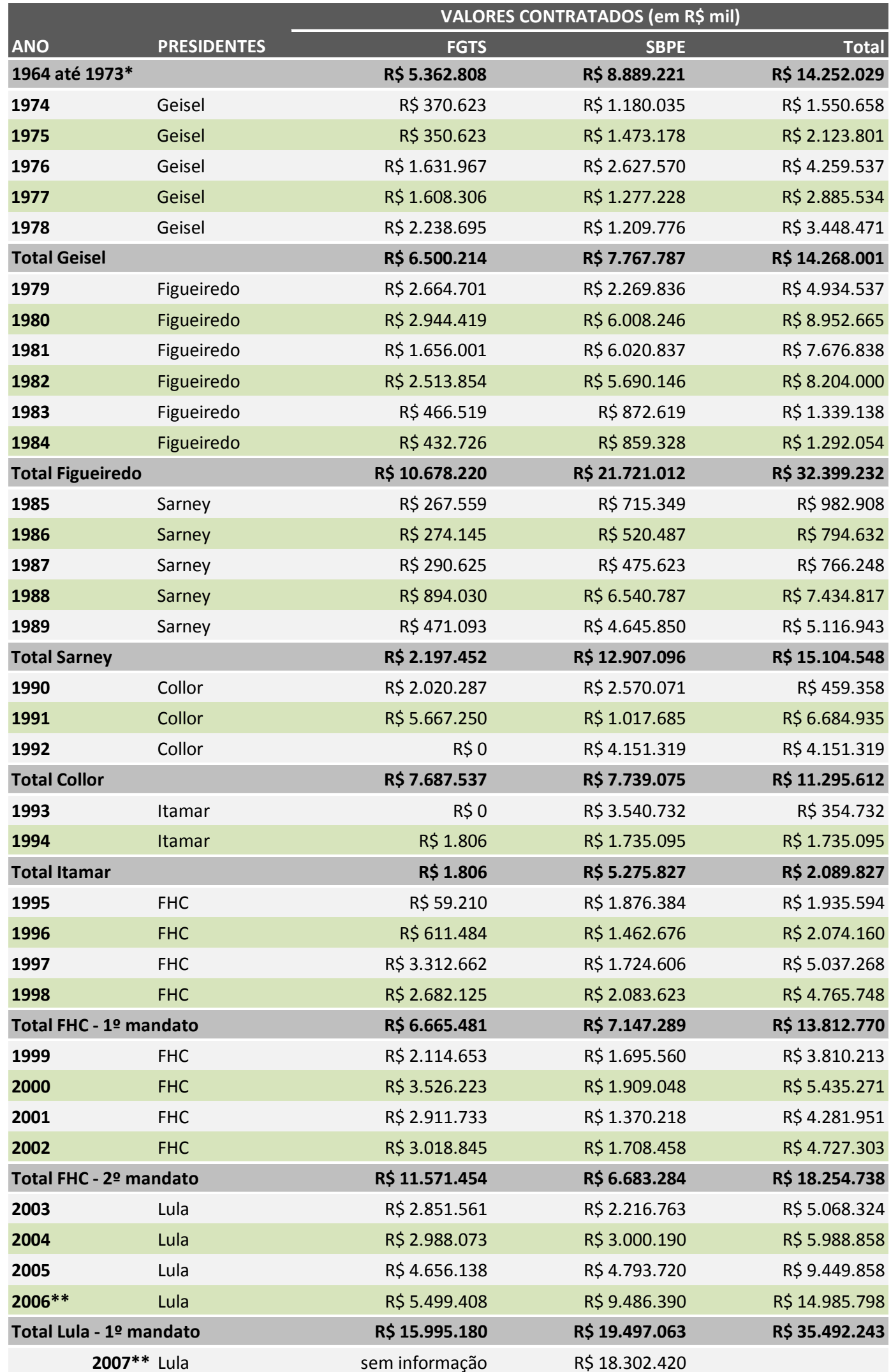

fonte: SUSAN/GECOA - Gerencial 040 Histórico habiatcional - CEF. Posição 30.set.2005 apud Lannoy, 2006.

* período militar governado pelos presidentes Castelo Branco, Costa e Silva e Médice.

** fonte: (IPEA, 2007) e (BRASIL/MCID, 2008) 
Tabela 3

Atendimentos habitacionais realizados com recursos do SFH (1964-2006)

\begin{tabular}{|c|c|c|c|c|}
\hline \multirow[b]{2}{*}{ ANO } & \multirow[b]{2}{*}{ PRESIDENTES } & \multicolumn{3}{|c|}{ ATENDIMENTOS HABITACIONAIS } \\
\hline & & FGTS & SBPE & Total \\
\hline \multicolumn{2}{|c|}{1964 até $1973^{*}$} & 520.000 & 454.000 & 974.000 \\
\hline 1974 & Geisel & 35.937 & 60.268 & 96.205 \\
\hline 1975 & Geisel & 77.417 & 64.512 & 141.929 \\
\hline 1976 & Geisel & 164.353 & 109.410 & 273.763 \\
\hline 1977 & Geisel & 209.709 & 58.004 & 267.713 \\
\hline 1978 & Geisel & 279.516 & 58.133 & 337.649 \\
\hline \multicolumn{2}{|c|}{ Total Geisel } & 766.932 & 350.327 & 1.117.259 \\
\hline 1979 & Figueiredo & 274.238 & 108.985 & 383.223 \\
\hline 1980 & Figueiredo & 366.808 & 260.534 & 627.342 \\
\hline 1981 & Figueiredo & 198.514 & 266.884 & 465.398 \\
\hline 1982 & Figueiredo & 282.384 & 258.745 & 541.129 \\
\hline 1983 & Figueiredo & 32.685 & 44.562 & 77.247 \\
\hline 1984 & Figueiredo & 43.551 & 42.807 & 86.358 \\
\hline \multicolumn{2}{|c|}{ Total Figueiredo } & 1.198 .180 & 982.517 & 2.180 .697 \\
\hline 1985 & Sarney & 42.987 & 34.652 & 77.639 \\
\hline 1986 & Sarney & 44.350 & 62.312 & 106.662 \\
\hline 1987 & Sarney & 99.227 & 132.005 & 231.232 \\
\hline 1988 & Sarney & 98.249 & 181.834 & 280.083 \\
\hline 1989 & Sarney & 32.404 & 68.089 & 100.493 \\
\hline \multicolumn{2}{|c|}{ Total Sarney } & 317.217 & 478.892 & 796.109 \\
\hline 1990 & Collor & 169.011 & 74.993 & 244.004 \\
\hline 1991 & Collor & 356.032 & 41.050 & 397.082 \\
\hline 1992 & Collor & 0 & 64.887 & 64.887 \\
\hline \multicolumn{2}{|c|}{ Total Collor } & 525.043 & 180.930 & 705.973 \\
\hline 1993 & Itamar & 0 & 53.708 & 53.708 \\
\hline 1994 & Itamar & 72 & 61.384 & 61.456 \\
\hline \multicolumn{2}{|c|}{ Total Itamar } & 72 & 115.092 & 115.164 \\
\hline 1995 & $\mathrm{FHC}$ & 12.466 & 26.592 & 39.058 \\
\hline 1996 & $\mathrm{FHC}$ & 71.321 & 38.286 & 109.607 \\
\hline 1997 & $\mathrm{FHC}$ & 192.021 & 35.407 & 227.428 \\
\hline 1998 & $\mathrm{FHC}$ & 275.565 & 28.687 & 304.252 \\
\hline \multicolumn{2}{|c|}{ Total FHC - 19 mandato } & 555.177 & 159.254 & 714.431 \\
\hline \multicolumn{2}{|c|}{$1999 \mathrm{FHC}$} & 180.075 & 35.459 & 215.534 \\
\hline \multicolumn{2}{|c|}{$2000 \mathrm{FHC}$} & 284.501 & 36.333 & 320.834 \\
\hline \multicolumn{2}{|c|}{$2001 \mathrm{FHC}$} & 239.289 & 35.755 & 275.044 \\
\hline \multicolumn{2}{|c|}{2002 FHC } & 197.187 & 28.902 & 226.089 \\
\hline \multicolumn{2}{|c|}{ Total FHC - $2^{\circ}$ mandato } & 901.952 & 136.450 & 1.038 .402 \\
\hline \multicolumn{2}{|c|}{2003 Lula } & 186.065 & 36.446 & 222.511 \\
\hline \multicolumn{2}{|c|}{2004 Lula } & 195.391 & 53.786 & 249.177 \\
\hline \multicolumn{2}{|c|}{2005 Lula } & 306.020 & 60.796 & 366.816 \\
\hline \multicolumn{2}{|c|}{ 2006** Lula } & 367.392 & 115.523 & 482.915 \\
\hline \multicolumn{2}{|c|}{ Total Lula - 19 mandato } & 687.476 & 266.551 & 1.321 .419 \\
\hline \multicolumn{2}{|c|}{ 2007** Lula } & sem informação & 195.891 & \\
\hline
\end{tabular}

fonte: SUSAN/GECOA - Gerencial 040 Histórico habiatcional - CEF. Posição 30.set.2005 apud Lannoy, 2006.

* período militar governado pelos presidentes Castelo Branco, Costa e Silva e Médice.

** fonte: (IPEA, 2007) e (BRASIL/MCID, 2008) 
O Ministério do Bem-Estar Social, então responsável pela questão habitacional adotou duas frentes de ação. A primeira delas buscou concluir cerca de 260 mil unidades contratadas no período anterior por meio dos poucos recursos do FGTS (abalado pelas ações do governo Collor), do Fundo de Desenvolvimento Social (FDS) e do Orçamento Geral da União (OGU). E a segunda, foi a criação de programas descolados do Sistema Financeiro de Habitação, voltados a construção de moradias, urbanização de favelas, produção de lotes urbanizados e melhorias habitacionais para o atendimento de famílias de baixa renda, como o Programa Habitar Brasil destinado a cidades acima de 50 mil habitantes e o Programa Morar Município para cidades de pequeno porte.

Ambos os Programas funcionaram com parcerias entre União e governos locais. Com recursos provenientes do Orçamento Geral da União e da cobrança do Imposto Provisório sobre Movimentação Financeira (IPMF), o governo federal se responsabilizou pelos custos de projetos técnicos, material de construção, urbanização e pavimentação. E os estados e municípios, entraram com contrapartida financeira, se responsabilizando pela prestação de assistência técnica, composta por equipe interdisciplinar, que deveriam auxiliar as famílias no processo de construção das casas, dado que o regime adotado deveria ser o mutirão ou autoconstrução.

Estes mecanismos efetivaram, ainda de forma incipiente, a descentralização de responsabilidades da política habitacional anunciada desde o processo da Constituinte. Um arranjo institucional reforçado, pelo fato de que para receber os investimentos da União era exigido dos municípios e estados a criação de conselho e fundo (municipal ou estadual) de bem-estar social, permitindo a participação da sociedade civil. Ficava evidente a influência de alguns princípios contidos na proposta do Fundo Nacional de Moradia Popular.

Em 1994 a fala de Paulo Conforto liderança do UMM-SP, decorrente do processo de discussão em torno do PL do FNMP que vinha ocorrendo no Congresso, expressava otimismo e conviç̧ão sobre unanimidade em relação à proposta da autogestão como uma alternativa possível:

“...o nosso projeto do Fundo Nacional que está em Brasília fala da possibilidade de gestão pela própria comunidade. Isso já não é mais contestado por nenhum setor. Os representantes da CEF admitem essa possibilidade, os empresários, os secretários de habitação de todo país admitem, enfim, todo mundo entende que realmente essa 
possibilidade é uma das alternativas. Acho que num país onde falta tanta habitação ninguém pode excluir qualquer alternativa de produção." (CONFORTO, apud SILVA, 1994:78).

Infelizmente Conforto tinha se equivocado, pois às vésperas da eleição presidencial o PL não foi votado, quando faltava apenas encaminhá-lo ao Plenário para sua apreciação e aprovação. O mesmo processo vinha ocorrendo com o Projeto de Lei de Saneamento Ambiental, que já se encontrava aprovado pelo Senado faltando apenas ser sancionado pelo então presidente recém empossado Fernando Henrique Cardoso que veta o projeto na íntegra ${ }^{66}$.

Na caravana de 1995, realizou-se uma audiência pública com então Ministro do Planejamento e Orçamento, José Serra, responsável pela pasta da habitação. Desta audiência tirou-se a conclusão de que este governo era contra fundos que vinculassem orçamento federal, e que apesar da pasta da habitação estar no lugar central na estrutura institucional federal, a intervenção do governo não iria além de uma gestão centralizada de diretrizes legais e administrativas pautadas pela perspectiva neoliberal (PAZ, 1996).

Os mecanismos do parlamento brasileiro permitiram que o projeto de criação do FNMP não entrasse em pauta, apesar da obrigatoriedade do cumprimento de toda tramitação dentro do legislativo e proibição de arquivamento de Projeto de Lei de Iniciativa Popular (PAZ, 1996:149). Ao longo desses anos o PL permaneceu parado, contrariando os dispositivos constitucionais que dão prioridade de votação aos projetos dessa natureza.

"Ele (o projeto de lei) volta e começa a passar comissão por comissão. De 95 a 96, nada. Depois, o Nilmário Miranda recomeça todo o caminho de volta. Aprovar na CDU (Comissão de Desenvolvimento Urbano), na comissão de Finanças, que o Evilásio passou como relator, depois foi para o CCJ (Comissão de Constituição e Justiça). Mas era uma comissão a cada dois anos..." (Evaniza Rodrigues, 27.02.2008).

\subsection{Autogestão pelo país: experiências dos anos 90}

Se na esfera federal o projeto de criação do FNMP permaneceu em "banho-maria", verificou-se que em alguns municípios e estados do país as conseqüências dessa iniciativa

\footnotetext{
${ }^{66}$ A Lei Nacional de Saneamento Ambiental (Lei no 11.445) foi aprovada somente em janeiro 2007.
} 
foram positivas. Por um lado, estavam os municípios que se apropriaram do modelo proposto pela lei e criaram fundos e conselhos de habitação para a condução de suas políticas públicas, como os municípios de Belo Horizonte e Porto Alegre. E por outro, em meio ao contexto de amadurecimento do processo de descentralização e democratização política, ocorreram situações em que diversas iniciativas locais por parte do poder público e organizações civis buscaram fomentar por diferentes meios o desenvolvimento de projetos habitacionais autogeridos.

Coube aqui um esforço de demonstrar a partir de sete processos que ocorreram ao longo dos anos 90 a diversidade dessas experiências autogestionárias resultantes tanto do contexto social, econômico, político e cultural de cada cidade em que foram implementadas, quanto da organização das famílias participantes do processo.

\subsubsection{Belo Horizonte - MG.}

Em Belo Horizonte na gestão de Patrus Ananias ${ }^{67}$, a partir de 1994 foram implantados o Fundo Municipal de Habitação Popular, o Conselho Municipal de Habitação composto por representantes da sociedade civil e poder executivo, e ainda a Política Municipal de Habitação que passou a nortear as ações da prefeitura com diretrizes que priorizavam as demandas por habitação coletiva (SOUZA, 2007). Concomitantemente, foi implementado o Orçamento Participativo com base na experiência de Porto Alegre, pelo qual era debatida a destinação de $10 \%$ do orçamento municipal.

Nos primeiros processos, grande parte deste orçamento foi destinada à habitação, em decorrência da organização dos movimentos de moradia que estavam mobilizados em função do I Fórum dos Sem Casa que reuniu 57 associações, deixando explicita a importância de sua demanda e capacidade de reivindicação. A partir de 1996, buscando corrigir as distorções do OP, a prefeitura criou o Orçamento Participativo de Habitação (OPH) e, por sugestão de técnicos da Companhia Urbanizadora de Belo Horizonte (URBEL) que tinham entrado em contato com as experiências de São Paulo e Ipatinga, elaborou o Programa de

\footnotetext{
${ }^{67}$ As entrevistas de Antônia de Pádua da CMP e Ênio Nonato da CONAM retrataram a experiência de participação do processo de coleta de assinatura para o projeto de lei do FNMP, e do posterior programa de produção habitacional por mutirão autogerido e do Orçamento Participativo da Habitação criados durante a gestão municipal de Patrus Ananias (1992-1995).
} 
Apoio à Moradia por Autogestão. Entre 1996 e 2005 foram contratados 11 empreendimentos beneficiando 1.247 famílias $^{68}$ que apresentaram resultados positivos, entretanto, diminutos se tomarmos como base a demanda total de 13.548 famílias que compõem as propostas aprovadas pelo $\mathrm{OPH}^{69}$. As dificuldades enfrentadas para efetivar a construção dos projetos se deram especialmente pela insuficiência de recursos do orçamento municipal para viabilizar infra-estrutura urbana e construção de habitações para esse montante de famílias, demandando uma composição de investimentos de outras esferas, então inexistentes.

\subsubsection{Ipatinga - MG}

Antes da experiência de Belo Horizonte, a cidade mineira de Ipatinga entre 1990 e 1997 viabilizou a produção de 684 unidades habitacionais em regime de mutirão autogerido (CONTI, 1999). A influência do Funaps-Comunitário e a presença de técnicos que haviam participado de processos participativos na gestão do estado de Minas Gerais foram fatores estruturantes da ação, elaborada pela administração de Chico Ferramenta junto com a Associação Habitacional de Ipatinga. Apesar de considerar a experiência positiva, Conti (1999) ressalta alguns aspectos prejudicais ao andamento da proposta transplantada de São Paulo pela Prefeitura de Ipatinga, sem que fossem consideradas algumas características próprias da cidade.

A estreita relação estabelecida entre associação de moradores e administração pública ao longo do tempo tornou-se outro forte limitador de um processo que pretendia ser autogestionário. Somados a isso, não foi possível estabelecer uma relação de parceria entre a assessoria técnica externa à cidade e a associação, conduzindo a um longo do processo de desgaste e à fragilização do papel da Assessoria. A ausência de um fundo e da formatação de um programa público foram os fatores que impediram a maior continuidade à ação que dependia do restrito orçamento municipal e de parcerias privadas para viabilizar cada empreendimento.

\footnotetext{
${ }^{68}$ Segundo dados da SMAHAB de 2005, apresentado por Souza (2007), entre estes empreendimentos estavam algumas propostas que foram viabilizadas ao serem contempladas pelo Programa Crédito Solidário em parceira com a PMBH a partir de 2004.

${ }^{69}$ Segundo dados da SMAHAB de 2005, citados por Souza (2007), trata-se do total de famílias que tinham sido contempladas pelas propostas do OPH até 2005.
} 


\subsubsection{Fortaleza - CE}

No caso de Fortaleza descrito por Vilanova $(2005)^{70}$, a proposta de autogestão viabilizada pelo governo estadual a partir de 1992, apresentou outras questões. O Programa de Desenvolvimento Urbano, denominado "Comunidades" da gestão de Ciro Gomes, realizou convênios com associações que contaram com o assessoramento da ONG Cearahperiferia às famílias envolvidas nos processos de mutirão, capacitadas para as atividades de obra e gestão financeira. Apesar de constituir uma experiência bem diferente dos mutirões tradicionais como os desenvolvidos pela SEAC do Governo Sarney, a idéia do 'favor' impregnada nas relações entre Estado e sociedade prevaleceu nesta experiência associativa. Segundo Vilanova (2005), para a maioria dos envolvidos ficou a percepção do “... acesso à habitação tido como 'dádiva' concedida pelo Estado caridoso". Somados ao fato do significado da conquista da casa própria se sobrepor à percepção do ganho coletivo, revelouse a fragilidade dos processos de participação, de consciência política e de conquista de direitos.

\subsubsection{Rio de Janeiro - RJ}

As experiências do Rio de Janeiro e Goiânia se assemelham pelo fato de terem sido processos que ocorreram independentemente de uma ação ou programa públicos de autogestão. A Fundação de Direitos Humanos Bento Rubião do Rio de Janeiro a partir de 1995 (CORRÊA, 2007) criou, por meio de doação de recursos da Misereor (entidade alemã), um Fundo Rotativo a ser gerido por conselho gestor composto por representantes das cooperativas de famílias e da Fundação, depois de fracassadas as negociações com a prefeitura do Município para construção de um programa institucional de produção habitacional por cooperativas, e de infrutíferas tentativas de captação de recursos junto ao governo federal para viabilizar o empreendimento.

Com os recursos do fundo rotativo foi possível construir inicialmente 82 habitações por meio da autogestão e ajuda mútua com assessoramente técnico realizado por uma equipe interdisciplinar da própria Bento Rubião. Em 2001 o fundo rotativo recebeu nova doação de recursos, agora da Fundação Interamericana, que somados aos recursos

\footnotetext{
${ }^{70}$ Sobre essa experiência consultar LOPES e RIZEK (2005).
} 
retornados dos primeiros empréstimos, viabilizou a produção de mais 61 unidades habitacionais nos mesmos moldes.

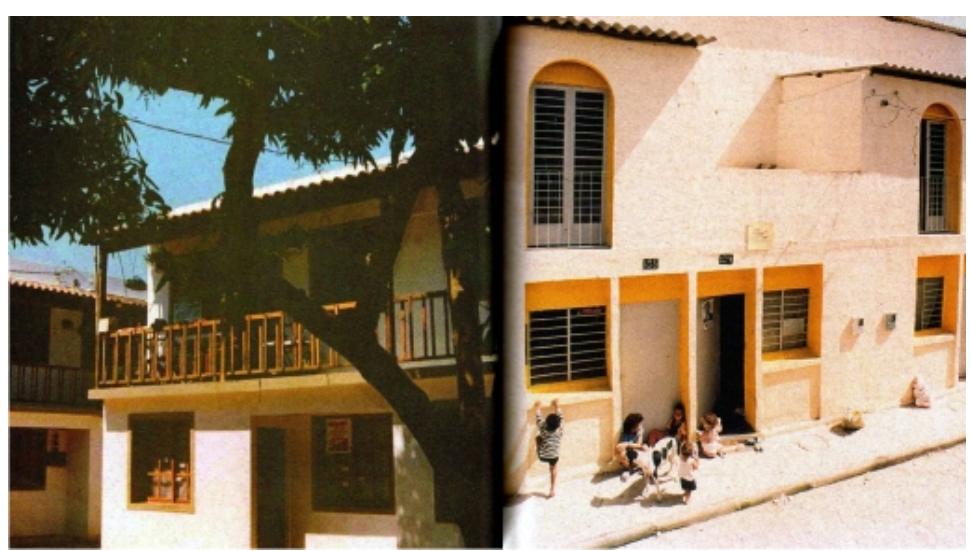

Cooperativa Shangri-lá e Ipiiba: produção habitacional autogerida com recursos do Fundo Rotativo e assessoramento feito pela Fundação Bento Rubião, Rio de Janeiro - RJ.

fonte: (CORRÊA, 2007)

\subsubsection{Goiânia - G0}

A experiência da União Estadual de Moradia Popular de Goiânia também foi viabilizada por meio de doação de recursos da entidade internacional Misereor diretamente à cooperativa que produziu o bairro Goiânia Viva, e segundo Vidal Barbosa ${ }^{71}$ foi mais um exemplo de produção habitacional por mutirão e autogestão. A partir de 1993 após negociação, a prefeitura de Darci Arccosi fez a desapropriação de terreno e repassou-o para o movimento, que por meio de recursos da entidade alemã, se responsabilizou pela gestão e coordenação da execução das obras das casas construídas por meio de mutirão, sem que houvesse acompanhamento técnico nos moldes das assessorias presentes nas experiências anteriores. Sob a coordenação do movimento o material de construção era comprado e distribuída entre as famílias, que aos finais de semana, construíam suas casas em regime de mutirão. Apesar da utilização do termo autogestão pelo entrevistado, a descrição do

\footnotetext{
${ }^{71}$ Quando questionado a respeito da origem da idéia de se fazer o processo em autogestão, Vidal respondeu: "Surgiu do próprio movimento. Quando nós ocupávamos, nós naturalmente fazíamos o processo de construção em autogestão. A gente fazia em mutirão a casa de um num final de semana, depois a casa de outro no outro final de semana. A cooperativa ficava responsável por juntar o dinheiro pra poder fazer a compra de material. A gente fazia isso de forma inconsciente" (Vidal Barbosa,15.10.2008).
} 
processo nos pareceu aproximar mais de um autoempreendimento, ainda muito freqüente neste município ${ }^{72}$.

\subsubsection{Mato Grosso do Sul}

O parecer técnico social sobre o processo de produção habitacional da experiência desenvolvida pelo Movimento Nacional de Luta por Moradia do Mato Grosso do Sul por meio do programa estadual denominado Che Roga $\mathrm{Mi}^{73}$, a partir de 1999 , em convênio com governo do estado e parceria com prefeituras mostra que nem sempre é preciso apropriarse do termo autogestão para exercer de fato os princípios de uma atividade autogerida:

“... a população tem respeitado seu direito de ser ouvida de forma coletiva, através das reuniões no canteiro de obra, onde todos têm o direito de concordar ou discordar, de optar, de ser levada em consideração, enfim de exercer seu papel como parte integrante de um grupo mais amplo. (...) a população passa a ser junto com órgãos responsáveis pela intervenção, sujeito e não apenas objeto das ações, tendo um papel ativo na gestão do processo como todo." (FRANCISCO, s/d)

E ainda, ao se referir ao programa de intervenção habitacional ressalta que este processo $^{74}$,

"É antes de tudo, uma forma organizada de se encarar os problemas, (...) onde se obtém como resultado não só a moradia, mas também um salto de qualidade a nível da (sic) organização da população" (FRANCISCO, s/d).

\subsubsection{Porto Alegre - RS}

E por fim, a experiência do Programa de Cooperativas Habitacionais da Prefeitura de Porto Alegre, que passou a funcionar a partir de 1993, atuando em parceria com as

\footnotetext{
72 Em visita realizada a Goiânia em junho e outubro de 2008 conhecemos experiências de autoempreendimento e/ou auto-financiamento realizadas pelos movimentos organizados: entre elas, o empreendimento João Paulo II (do Movimento de Reforma Urbana - MRU) e o Serra Azul (da UEMP-GO).

${ }^{73}$ Elaborado por Neuza Alves Francisco. Parecer técnico social ao Programa Che Roga Mi mutirão - convênio firmado com MNLM em Mato Grosso do Sul. Mato Grosso do Sul, Secretaria de Habitação e Infra-estrutura, em mimeo não datada.

${ }^{74}$ Segundo o relatório citado acima foram promovidas a construção de cerca de sete mil unidades habitacionais por meio de mutirão e uso da tecnologia Beno.
} 
cooperativas habitacionais de maneira distinta das parcerias estabelecidas nos casos de São Paulo e Uruguai (FRUET, 2004). O principal papel do poder público, por meio do Departamento Municipal de Habitação (DEMAHAB) era promover o apoio para a formação dessas cooperativas, o apoio às negociações de terra, bem como o assessoramento técnico, elaborando projetos e buscando fontes de financiamento para construção das unidades habitacionais.

Em 1994 foi criado o Fórum das Cooperativas Habitacionais Autogestionárias de Porto Alegre (FCHA), que a partir de 1997 passou a ter acesso aos recursos do Orçamento Participativo do Município. Este fórum realizava a distribuição de recursos por meio de empréstimos entre cooperativas destinados à compra de terrenos. Outra maneira de acessar a terra era por meio de recursos de poupança prévia realizada pela própria cooperativa. Ao longo dos anos 90 a maior dificuldade enfrentada por elas foi viabilizar recursos para a construção das unidades habitacionais.

Segundo Fruet (2004), em 1995 e em 1999, no início de cada da gestão de Fernando Henrique Cardoso no governo federal, o FCHA e o DEMAHAB encaminharam uma proposta de criação do Programa Pró-Cooperativas Habitacionais Autogestionárias à Secretaria de Desenvolvimento Urbano em Brasília. Essa proposta indicava a utilização dos recursos do FGTS, diretamente financiados às cooperativas como pessoas jurídicas e não individualmente, definia ainda a cooperativa como proprietária final do empreendimento que outorgaria aos seus cooperados o direito de uso das unidades habitacionais.

O único indício verificado que poderia atender parcialmente a essa demanda por parte do Governo federal ocorreu em 1996 quando foi criada a Carta de Crédito Associativa, mas ainda sim este programa impunha uma capacidade de endividamento elevado por família. Isso porque esse programa definia o indivíduo como beneficiário final do financiamento, em detrimento de um financiamento em nome da cooperativa, anulando as vantagens oferecidas pela poupança prévia, que permitia a presença de diferentes rendas familiares dentro do mesmo grupo.

Vimos que apesar de diversas iniciativas locais buscarem viabilizar a proposta autogestionária na produção habitacional, o principal impeditivo, naquele momento, estava na falta de alternativas de acesso a recursos mais significativos para viabilizar a produção 
habitacional do que os investimentos oriundos dos orçamentos municipais, montante que somente a esfera federal poderia prover.

\subsection{A política habitacional do Governo FHC}

A partir de 1995, embora se tenha apontado para uma visão mais integrada da questão habitacional com as ações de saneamento e aspectos ambientais, as atribuições da política urbana foram conduzidas de forma atomizada em inúmeras instituições (ligadas a diferentes ministérios) sem que houvesse uma coordenação. Neste momento, o Conselho Curador do FGTS passa a trabalhar com significativa autonomia, e segundo análise de Cardoso,

“... a reorganização do aparato institucional teve amplas conseqüências sobre o papel desempenhado pela Caixa Econômica Federal, que passou a ter sua atuação limitada ao papel de agente operador dos recursos do FGTS." (CARDOSO, s/d).

Vale destacar que em 1996, antecedendo a Conferência Habitat II, foi apresentada pelo governo a Política Nacional de Habitação. Este documento foi de fato a primeira iniciativa que buscou enfrentar a crise do SFH desde o momento em que foi deflagrada. Nele foi apresentada uma análise sobre as supostas causas do esgotamento do SFH e proposto um novo modelo ao sistema. Os principais aspectos levantados nessa análise foram a atuação insuficiente do $\mathrm{SFH},{ }^{75}$ seu esgotamento em função da grande dificuldade de captação de recursos, e as distorções na aplicação dos montantes financeiros e subsídios que beneficiaram as camadas de renda média e alta. Argumentou-se ainda que os problemas enfrentados foram decorrentes da centralização da gestão pública e da falta de controle social que pautaram as políticas anteriores.

Neste contexto, foi delimitado um novo modelo que apontava para universalização do acesso à moradia, admitindo que o foco de ação deveria ser as famílias de baixa renda, justificado pelo fato de $85 \%$ do déficit habitacional concentrar-se neste grupo da população. Somado a isso, foi assumida a incapacidade da política de Estado em resolver o problema da habitação por si, justificando assim a necessidade de fortalecer e melhorar os mecanismos

\footnotetext{
75 Pois em 30 anos produziu cerca de 5,6 milhões de unidades habitacionais em um universo total de 31,6 milhões de novas moradias construídas no país em SANTOS (1999).
} 
de atuação do mercado neste setor por meio de ações mais diversificadas, o que viria a ser a marca deste período. Foi defendida ainda, a descentralização da política como forma de ampliar a transparência da gestão e, portanto, do controle social sobre os programas.

A principal alteração proposta a partir de 1995 foi a do modelo de financiamento que antes estava voltado a produção habitacional e passa a ser destinado à comercialização de unidades habitacionais.

"A concessão do financiamento direto ao consumidor é vista como uma forma de o governo auxiliar a sociedade (sem discriminação daqueles cidadãos que trabalham em atividades informais e/ ou habitam em moradias informais) a resolver seus problemas habitacionais, sem, contudo, tomar para si essa tarefa" (SANTOS, 1999:25).

Para responder a essa nova diretriz foi criado o Programa Carta de Crédito Individual, que utilizou o FGTS como fonte de recurso, destinado ao atendimento de famílias até 12 salários mínimos que buscavam as agências da CEF, onde eram avaliados a capacidade de endividamento familiar e, proporcionalmente, concedido o crédito diretamente ao "consumidor". Em 1996, também por meio dos recursos do FGTS, foram criados os programas Carta de Crédito Associativo, nos mesmos moldes da modalidade individual, financiados diretamente à pessoa física organizada de forma associativa, como sindicatos, associações, entidades privadas e cooperativas, e ainda às COHABS, como operadores do crédito, e o Programa de Apoio à Produção de Habitação, operados por construtoras, destinado ao atendimento de famílias com faixa de renda até 20 salários mínimos ${ }^{76}$.

Em julho de 1998, esses programas habitacionais passam por forte abalo. Por um lado, as contratações via FGTS ao setor público foram restringidas ainda mais, e conforme apontado por Cardoso tal processo, ocorreu em função da

“... alta sensibilidade do FGTS à crise econômica" e também à política de contenção de despesas, que passa a ser largamente utilizada pelo governo como estratégia de enfrentamento do déficit público." (CARDOSO, s/d).

\footnotetext{
76 O Programa Carta de Crédito Individual foi criado pela Resolução no 184 de 1995 do CCFGTS, a Carta de Crédito Associativo foi criado pela Resolução no 239 de 1996 do CCFGTS e Programa Apoio à Produção de habitação foi criado pela Resolução no 238 de 1996 do CCFGTS.

${ }^{77}$ Neste período, desencadeou no mundo como efeito dominó, a crise financeira que teve início na Ásia, e por isso foi denominada como "crise asiática". Pela primeira vez se questionou a lógica econômica da globalização
} 
No quadro de extremo controle dos gastos públicos, exposto acima, os empréstimos habitacionais continuavam restritos ao setor privado. Em 1999 a CEF apresentou ao governo a proposta do Programa de Arrendamento Residencial (PAR) ${ }^{78}$ destinado ao atendimento de famílias até seis salários mínimos selecionadas pelos municípios, prioritariamente pertencentes a regiões metropolitanas ou com população maior de 100 mil habitantes $^{79}$.

As alternativas de atendimentos pelo setor privado como a Carta de Crédito e posteriormente o PAR, que apresentaram subsídios implícitos nas taxas de juros ${ }^{80}$ inferiores as do mercado, certamente colocaram à disposição recursos mais baratos, porém, não foram subsídios suficientes para alcançar as famílias foco da política proposta em 1996, com renda inferior a três salários mínimos. Em especial, o Programa Carta de Crédito proposto por este governo, que acabou financiando habitações subsidiadas para quem poderia obter empréstimos no mercado financeiro (AMARAL, 2001b). Este modelo acabou repetindo os mesmos deslizes das políticas de habitação anteriores, que conforme diagnosticadas pela $\mathrm{PNH}$, deveriam ser corrigidos.

Em 2001, foi criado pela Medida Provisória 2.212 o Programa de Subsídio à Habitação de Interesse Social (PSH), que contava com recursos do OGU e complementação financeira por parte do poder público local. Tal programa teve como objetivo conceder subsídios diretos às famílias de renda até três salários para aquisição (compra de imóvel pronto, ou produção) de unidades habitacionais ${ }^{81}$. Vale destacar que esta foi a primeira medida desde 1995 que visou a efetiva provisão de unidades habitacionais novas às famílias até três salários mínimos. Até então, as formas de atendimento a essa faixa de renda se restringiam

\footnotetext{
e a aparente unidade do Consenso de Washington. No Brasil, para responder à crise foi criado no governo FHC - PROER (Programa de Estímulo à Reestruturação do Sistema Financeiro), um programa de socorro as instituições financeiras que funcionou entre 1995 a 2001, no qual o Estado investiu recursos públicos para salvar os bancos que acumulavam prejuízos.

${ }^{78}$ No início de 2001 o PAR foi criado pela Lei Federal no 10.188.

${ }^{79}$ Essas famílias arrendam por 15 anos o imóvel construído pela iniciativa privada, que obtém o crédito junto à CEF (operadora do Programa) para a construção das unidades habitacionais. Ao final deste prazo de arrendamento, existe a opção das famílias se tornarem proprietárias, quitando a diferença entre o montante pago pelo arrendamento e o valor de mercado do imóvel.

${ }^{80}$ Taxas de juros no PAR à época eram cobradas pela TR + média de $6 \%$ a.a. e no Carta de Crédito as taxas de juros para famílias até doze salários mínimos variavam em torno de TR $+8 \%$ a.a.

${ }^{81}$ Os recursos são ofertados por meio de leilão à instituições financeiras que oferecem os menores custos de operação para garantir o repasse dos subsídios ao beneficiário final.
} 
aos Programas Habitat Brasil e Pró-moradia, que por sua vez, eram voltados à urbanização de assentamentos precários, e que a partir de 1998 passaram por forte restrição de crédito.

Se considerarmos verdadeira a afirmação presente no documento do IPEA de que

"Implícita à política, (...) está a crença de que os mecanismos de mercado podem cuidar eficientemente da provisão de moradias para a maior parte da população brasileira" [grifo nosso] (SANTOS, 1999:27),

ao aproximá-la da situação na qual 81,6 \% da população têm renda familiar mensal inferior a três salários mínimos e concentra $90,3 \%$ do déficit habitacional, estaríamos caindo numa contradição. Isso porque a maior parte da população brasileira (81,6\%) compõe um perfil de renda que não tem capacidade de endividamento para acessar crédito habitacional, e ainda oferece alto risco de inadimplência, ou seja, não apresenta condições adequadas exigidas pelo mercado para acessar um financiamento habitacional.

Tabela 4

Distribuição percentual do Rendimento familiar per capita (2005)

\begin{tabular}{lccc} 
REGIÕES & ATÉ 3 S.M. & 3 à 5 S.M. & MAIS DE 5 S.M. \\
\hline Norte & 87,5 & 4,3 & 5,0 \\
Nordeste & 88,4 & 3,0 & 3,2 \\
Sudeste & 76,9 & 8,8 & 8,3 \\
Sul & 80,0 & 9,4 & 7,9 \\
Centro-oete & 81,9 & 6,7 & 7,9 \\
BRASIL & $\mathbf{8 1 , 6}$ & $\mathbf{6 , 9}$ & $\mathbf{6 , 4}$
\end{tabular}

fonte: IBGE, 2006/ dado PNAD-2005.

Tabela 5

Distribuição percentual do deficit habitacional urbano por faixa de renda familiar mensal (2006)

\begin{tabular}{lccc} 
REGIÕES & ATÉ 3 S.M. & 3 à 5 S.M. & MAIS DE 5 S.M. \\
\hline Norte & 91,2 & 5,0 & 3,8 \\
Nordeste & 95,0 & 2,8 & 2,2 \\
Sudeste & 89,9 & 6,2 & 3,9 \\
Sul & 85,1 & 9,0 & 5,9 \\
Centro-oete & 88,3 & 6,1 & 5,6 \\
BRASIL & 90,7 & $\mathbf{5 , 5}$ & $\mathbf{3 , 8}$
\end{tabular}

fonte: BRASIL/MCID/SNH. Deficit Habitacional no Brasil, 2006. Ministério das Cidades, Secretaria Nacional de Habitação e Fundação João Pinheiro. Brasília, 2008. 
A aplicação dos recursos destinados a habitação entre 1993 e 2002, nos governos dos presidentes Itamar Franco e Fernando Henrique Cardoso, se concentraram no atendimento das famílias acima de 5 salários, como mostra a Tabela 6 . Em nove anos, conforme apresentado por Zanboni (2004), foi aportado o montante total de R\$ 54 bilhões, distribuídos entre o OGU com R\$ 2,2bi (4,2\%), FGTS com R\$ 26 bi $(48,3 \%)$ e o SBPE com R\$ 25 bi $(47,5 \%)^{82}$. A aplicação de recursos oriundos do OGU para o atendimento às famílias com renda inferior a três salários mínimos representou, neste mesmo período, um investimento anual médio inexpressivo de $\mathrm{R} \$ 224$ milhões $^{83}$.

\section{Tabela 6}

Investimentos do governo federal*em habitação distribuidos por faixa de renda (1993-2002)

\begin{tabular}{lcc} 
FAIXA DE RENDA & $\begin{array}{c}\text { No ABSOLUTO } \\
\text { (em R\$ bilhões) }\end{array}$ & EM \% \\
\hline até 3 s.m. & 469,800 & 8,7 \\
\hline a 5 s.m. & 318,600 & 5,9 \\
\hline 5 a 10 s.m. & 1247,400 & 23,1 \\
\hline acima de 10 s.m. & 3364,200 & 62,3 \\
\hline TOTAL & $\mathbf{5 4 , 0 0 0}$ & $\mathbf{1 0 0}$ \\
\hline
\end{tabular}

fonte: (Zamboni, 2004 apud Fagnani, 2006)

* OGU, FGTS e SBPE

A população brasileira que compõe os cerca de $90 \%$ do déficit habitacional brasileiro toma pra si, sem ter alternativas formais, o esforço de solucionar (de maneira parcial e precária) o seu problema de moradia resultante da isenção, ao longo da história, por parte do Estado de sua responsabilidade ao alinhar-se à diretrizes e interesses do setor privado, conforme descrito neste capítulo. Para se ter uma dimensão da importância desse fato, somente entre 1995 e 1999 do total de 4,4 milhões de unidades habitacionais novas empreendidas no país, 700 mil foram promovidas pela iniciativa privada e pelo setor público, as demais (3,7milhões) foram auto-empreendidas pela população (BRASIL/MCID, 2004).

\footnotetext{
82 Citado por FAGNANI (2006). População e bem-estar social no Brasil: 40 anos de ausência de política nacional de habitação popular (1964-2002).

${ }^{83}$ Para perceber o quanto diminuto foi esse investimento, tomou-se a comparação apresentada por Fagnani (2006) que afirma que os "dez anos de aplicações em programas para a habitação popular (...) representam menos de que o acréscimo no estoque da dívida interna gerado por uma simples decisão do Banco Central de aumentar a taxa de juros em $1 / 2$ ponto percentual. Ou mesmo alguns poucos dias de pagamento de juros da dívida (em 2005, essa fatura totalizou cerca de $R \$ 500$ milhões por dia)".
} 


\subsection{A sociedade civil modificada e a defesa da autogestão}

A sociedade civil organizada se modificou nos anos 90 , e presenciou a reorientação dos movimentos populares urbanos influenciadas pela indefinição das políticas públicas e pela urgência da questão social que se mostrava mais evidente. Conforme ressaltou Ribeiro (1995), essas mudanças foram essencialmente decorrentes de uma conjuntura particular, marcada pelo amadurecimento do processo de redemocratização do país, da reestruturação econômica e da reorganização do Estado, calcada nos princípios neoliberais.

Essa nova conjuntura tornou as diferenças entre grupos componentes da sociedade civil mais nítidas, principalmente em função dos limites impostos pelo Estado às políticas sociais, dissolvendo assim a aparente unicidade que se via nos anos 70 e início dos anos 80, e com isso, estimulando a dispersão das pressões políticas. As divergências em relação a entendimentos e propostas relacionadas às práticas políticas, garantias de diretos e papel do Estado marcaram a separação de visões entre as organizações sociais nascidas na década de $70^{84}$ e o associativismo fortalecido dos anos $90^{85}$.

Ribeiro (1995) afirma ainda, que a falta de um projeto socialmente consistente no plano nacional estimulou a concentração das expectativas em torno dos processos de descentralização e participação social, e da visão municipalista apropriada pelo campo de esquerda e pelos movimentos populares.

A abertura de canais institucionais de participação fez emergir um conjunto de relações conflituosas e complexas que se relacionavam à identidade social e territorial do movimento popular e a sua representatividade. O movimento popular passou a participar de múltiplas arenas políticas quando, além da defesa de direitos, se viu obrigado a debater questões relacionadas aos limites financeiros das administrações públicas, às novas formas de financiamento, à resistência as privatizações de serviços públicos, dentre outras pautas relacionadas à racionalidade econômica deste período. E com isso deparou-se com a

\footnotetext{
${ }^{84}$ Caracteriza pelo direito de reivindicar direitos e pelo direito de adotar novos padrões de comportamento, os movimentos sociais nascidos nos anos 70 persistem em buscar a universalização dos direitos políticos, sociais e civis, baseados em critérios da igualdade e justiça social e atribuem ao Estado à responsabilidade de apresentar soluções construídas participativamente, bem como de regular as ações do mercado.

${ }^{85}$ Este outro grupo carrega entendimentos e projetos políticos alinhados às reformas do Estado induzidas pelos princípios neoliberais que transformaram cidadãos portadores de direitos em duas categorias de sujeitos: de um lado, os clientes que podem pagar pelos serviços promovidos pelo mercado e de outro, os receptores de generosidade e favores.
} 
necessidade de uma organização institucional, com a exigência de certo grau de profissionalização e maior conhecimento técnico para atuar nesse novo contexto e lidar com propostas diversas.

Em meio aos novos dilemas expostos acima, foi posto aos movimentos populares a necessidade de reforçar a articulação entre eles, buscando contrapor a dispersão da ação social e fortalecer sua atuação política a partir da criação de redes e entidades nacionais.

Com exceção da CONAM, as demais entidades nacionais de movimento de luta por moradia se formaram nos primeiros anos da década de 90, sendo a última delas a União Nacional Moradia Popular (UNMP) em decorrência do processo da construção do Projeto de Lei do Fundo Nacional de Moradia Popular (FNMP) ${ }^{86}$. A UNMP nasce em 1994 no primeiro encontro nacional realizado em Minas Gerais com representantes de movimentos de São Paulo, Ipatinga, Rio de Janeiro e Paraná.

As entidades nacionais apresentavam divergências relacionadas às concepções da construção de movimento social, estratégias de enfrentamento da questão habitacional e da própria forma de sua organização e, especialmente entre a UNMP e o MNLM estava colada a discordância em relação à proposta da autogestão. Esta era defendida pela União Nacional, mas "... era encarada como uma proposta meio conivente, meio pelega..." (Evaniza Rodrigues, 27.02.2008) pelo Movimento Nacional que argumentava que para viabilizá-la criava-se uma relação de dependência com as prefeituras ${ }^{87}$.

Após a "derrota" simbólica em relação à proposta do FNMP, a UNMP avaliou que para demarcar posição, construir uma representação ampla e disputar pelas suas pautas de movimento de massa apoiado nos princípios da autogestão com efetiva participação popular era preciso agregar novos movimentos de outros estados que simpatizavam com suas

\footnotetext{
${ }^{86}$ A CONAM, Confederação Nacional de Associação de Moradores nasce em 1982 da articulação de moradores de bairros populares e favelas a partir do apoio de setores populares e sindicatos, vinculados originalmente ao PMDB. A Central dos Movimentos Populares nasce em 1993 da PRÓ-CENTRAL que desde 1989 articulava diferentes lutas, entre elas a moradia. A PRÓ-CENTRAL por sua vez, veio da ANAMPOS (Articulação Nacional de Movimentos Populares e Sindicais) que existia desde o início dos anos 80. Já o Movimento Nacional de Moradia Popular nasce em 1991, muito vinculado à ANSUR (Associação Nacional do Solo Urbano), entidade que desempenhava assessoramento técnico ao movimento.

${ }^{87}$ É importante ressaltar que hoje, com base nas entrevistas realizadas com as lideranças dos movimentos, os discursos apresentam poucas divergências. E se na pauta do Movimento Nacional o princípio da autogestão não é necessariamente um bandeira explícita como da UNMP, muitas lideranças do MNLM individualmente defendem a autogestão. É possível afirmar que a disputa acirrada que existia naquele momento em torno da autogestão, atualmente não está mais tão presente.
} 
propostas (PAZ, 1996). Para isso buscaram construir uma articulação nacional que rompesse com a forte identidade atribuída a União de Movimentos de Moradia de São Paulo (UMMSP) ${ }^{88}$ e decidiram então, como estratégia, filiar-se a Central dos Movimentos Populares (CMP) que tinha representatividade em todos os estados do Brasil.

"Porque a CMP (...) vem da ANANPOS, depois da Pró-CENTRAL e quando vira CMP ela já tinha uma representatividade no país inteiro e nas diversas frentes... E aí... Pra modificar essa visão que tinham sobre a União e autogestão... Quando a gente foi para a Central a gente conseguiu ir estado por estado, fazendo trabalho com as lideranças, mostrando a proposta de autogestão, mostrando o que a gente tinha feito, mostrando o que a gente tinha conseguindo e mostrando, justamente pelo contrario, que fazer autogestão não fazia a gente ficar mais pelego, e sim dava mais força para a gente fazer outras lutas... E mesmo nas épocas mais duras a gente conseguiu fazer atos fortes..." (Evaniza Rodrigues, 27.02.2008).

Entretanto, para avançar na construção dessa ampla representação nacional era preciso, segundo Rodrigues, que os novos integrantes dos demais estados estivessem convencidos pelo o que se lutava, já que o conceito da autogestão era totalmente novo e abstrato. Seria fundamental a partir de então, buscar formas de materializar a idéia que tanto defendiam. Assim, em 2001 foi organizada nacionalmente uma caravana ao Uruguai para mostrar de perto a legítima experiência cooperativa na produção habitacional por ajuda mútua.

"E nessa história a gente fortalece a proposta... Mas ainda faltava o que? Faltava para esses estados (aos movimentos de representação estadual) que estavam chegando a oportunidade de vivenciar, de ter uma experiência dessas... Porque tudo bem, um vai lá na casa do outro acha lindo, muito bonito, mas volta pra casa e nada... Então pra gente era fundamental construir o Crédito Solidário. Ou seja, construir um programa em nível nacional que pudesse fazer a autogestão em outros lugares..." (Evaniza Rodrigues, 27.02.2008).

\footnotetext{
${ }^{88}$ A UMM-SP ainda hoje exerce forte centralidade em relação aos demais movimentos estaduais da UNMP.
} 
2.9 Linha do Tempo: política habitacional, autogestão e movimento popular

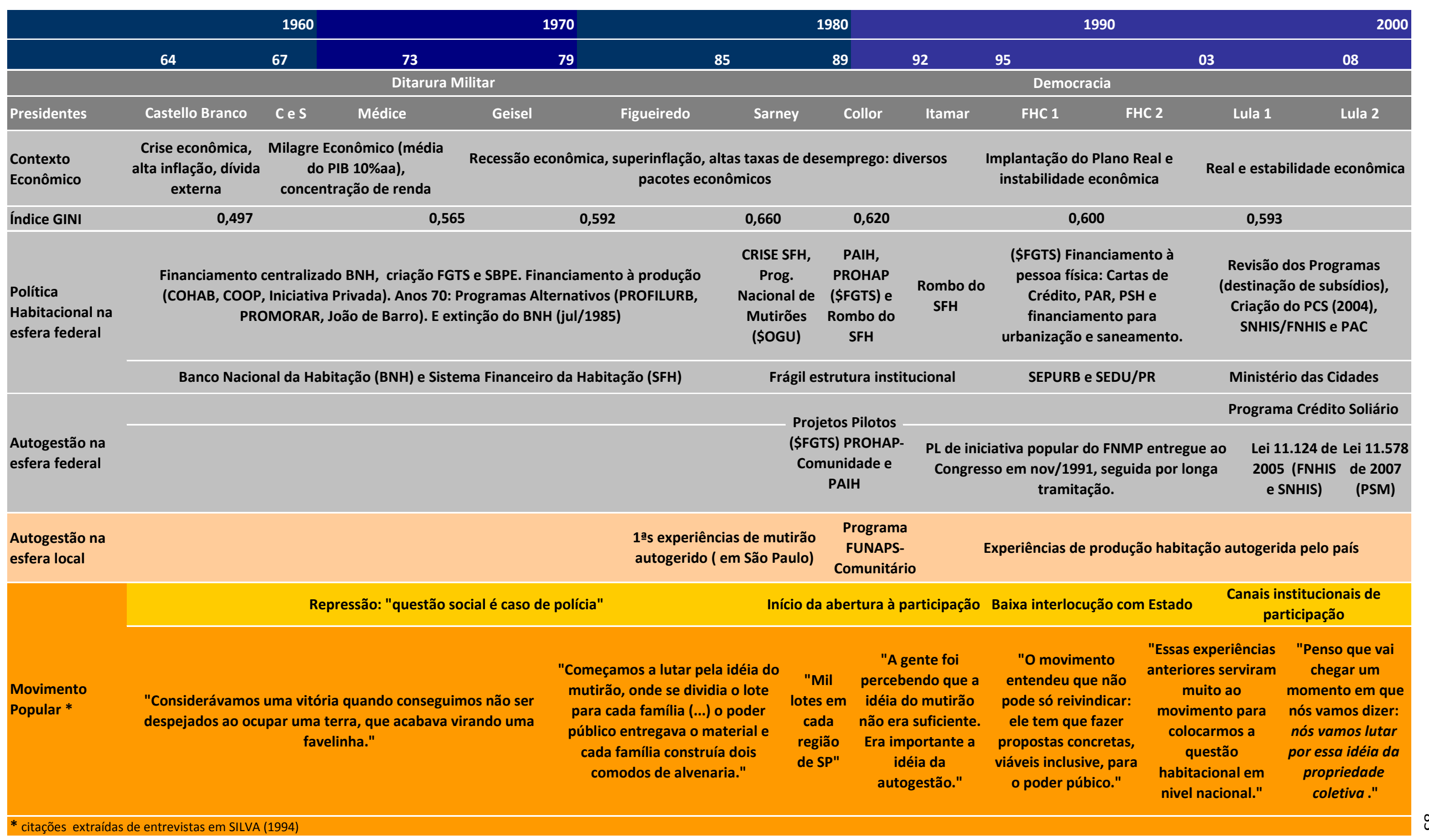




\section{A Política Habitacional do Governo Lula e o Programa Crédito Solidário}

No capitulo anterior discutimos como o princípio da autogestão tornou-se uma importante bandeira de luta do movimento de moradia, respeitada a heterogeneidade inerente aos diferentes grupos organizados, e como esses passaram a reivindicar a criação de um programa habitacional autogerido.

Partindo da tese de que o Programa Crédito Solidário (PCS) foi criado pelo Governo Lula em 2004 justamente como resposta a essa demanda, definimos como objetivo do presente capítulo estudar o processo de formulação e implementação do PCS - a partir de sua operacionalização no final de 2004 ao final de 2007. Momento em que foram totalizados $\mathrm{R} \$ 209.117 .925,19$ em investimentos do recurso do Fundo de Desenvolvimento Social, em 203 empreendimentos diferentes, totalizando o atendimento de 12.199 famílias em 21 estados da federação ${ }^{1}$.

Buscamos demonstrar como a criação do programa se encaixa na trajetória de luta do movimento de moradia junto ao governo federal, em especial à luta pela aprovação da Lei do Fundo Nacional de Moradia Popular, não sendo apenas de uma mera reivindicação pontual. E, ainda discutir qual tem sido o seu papel e o seu peso dentro da atual política nacional de habitação e no enfrentamento do déficit habitacional como um todo.

Para responder a esse objetivo, primeiro apresentamos uma breve história da estruturação da política habitacional do Governo Lula, identificando quais são as suas principais diretrizes e como essas foram implementadas dentro do contexto e das peculiaridades deste governo. Em seguida, discutimos a história em torno da formulação e implementação do Programa Crédito Solidário a partir do material coletado ao longo da pesquisa e das entrevistas realizadas com diferentes agentes participantes desse processo, buscando contrapor as diferentes visões do processo e as trajetórias percorridas por cada um desses agentes.

\footnotetext{
${ }^{1}$ Disponível em www.cidades.gov.br, acesso realizado em 20 de março de 2008.
} 


\subsection{A Política Nacional de Habitação do Governo Lula}

E nós vamos construindo juntos, porque muitas vezes somos nós que temos que convencer vocês de que vocês estão muito ousados, é preciso ter calma. Muitas vezes são vocês que têm que nos convencer de que nós estamos indo muito devagar e precisamos andar depressa porque o andor é de barro".

Presidente Luiz Inácio Lula da Silva,

Abertura da 3a Conferência Nacional das Cidades, novembro de 2007.

O Ministério das Cidades foi criado em 2003, sob o comando do ministro Olívio Dutra, com o propósito de superar o recorte setorial até então dado às políticas de habitação, de saneamento ambiental e dos transportes e trânsito urbano. A idéia central seria integrar essas políticas a partir do uso e ocupação do solo, construindo uma Política de Desenvolvimento Urbano de longo prazo, sustentável e contínua, que fosse capaz de reverter a histórica influência dos bancos públicos (BNH e posteriormente a CEF responsáveis pelos financiamentos habitacionais e de saneamento) nas definições dessas diretrizes políticas (BRASIL/MCID, 2004b), que como visto no capítulo anterior, trouxeram grandes prejuízos às cidades brasileiras.

Sua estrutura foi definida a partir de quatro secretarias nacionais: (1) Programas Urbanos, (2) Transporte e Mobilidade, (3) Saneamento Ambiental e (4) Habitação com as atribuições de

“... formular, fomentar, financiar e participar de uma construção cooperativa que tem como meta a reversão desse processo de piora da qualidade de vida urbana, que atente para inclusão social e a sustentabilidade ambiental" (MARICATO, 2006: 2).

Por trás dessas atribuições estava a responsabilidade de consolidar na esfera federal os princípios pautados pelo Movimento da Reforma Urbana e pelo Projeto Moradia ${ }^{2}$, resultado de anos de luta dos movimentos sociais pelo direto à cidade.

\footnotetext{
${ }^{2}$ O Projeto Moradia foi elaborado por grupo de técnicos e lideranças populares e apresentou uma proposta estruturada de política pública de âmbito nacional para enfrentamento do "problema habitacional" do país. 0 documento traçou diagnóstico do déficit habitacional a ser enfrentado, definiu custos de investimentos, diretrizes para utilização de fontes de recursos distintas e de implementação da política de forma democrática e participativa.
} 
Outra característica fundamental deste novo arranjo institucional estava relacionada a gestão democrática participativa, sugerida por Maricato como uma "construção cooperativa". Esta construção teve como pilares de sustentação a criação, ainda no início da gestão, de canais institucionais de participação como as Conferências das Cidades, ocorridas em 2003, 2005 e 2007, e o Conselho das Cidades. A criação destas esferas corroborou com a diretriz de desenvolver uma política institucional com participação da sociedade pressupondo amplo diálogo com diversos segmentos sociais que atuam no espaço urbano.

Foram muitas as contribuições oriundas das propostas aprovadas nas Conferências Nacionais e os pactos estabelecidos no Conselho das Cidades na definição dos princípios, objetivos e ações do Ministério das Cidades, efetivadas ou em implantação, como os exemplos da própria Política Nacional de Habitação (2004) e da retomada da pauta do Fundo Nacional de Moradia Popular estacionada no Congresso.

Entretanto, essas esferas vêm sofrendo progressivamente, com a falta de protagonismo nas definições de determinadas estratégias do governo. Em certa medida, pelo fato de não possuírem caráter deliberativo, e principalmente pelo abandono de alguns princípios fundantes do Movimento da Reforma Urbana após a mudança da direção do ministério, assunto que trataremos com mais cuidado a seguir ${ }^{3}$.

Entre as contribuições participadas do Conselho das Cidades estava a Política Nacional de Habitação (BRASIL/MCID, 2004) que foi elaborada ao longo de 2004 e definiu como meta central a promoção do acesso à moradia digna a todos os segmentos da sociedade, em especial às faixas de menor renda, em consonância com a Política Nacional de Desenvolvimento Urbano. Para responder às diretrizes dessa Política de Habitação o Governo definiu ações prioritárias. Entre elas estavam a revisão e a articulação entre os aspectos fundiários e aspectos relacionados ao financiamento habitacional, e ainda a reestruturação do arranjo institucional desta política.

\footnotetext{
${ }^{3}$ As deliberações do PAC (Programa de Aceleração do Crescimento), por exemplo, nas áreas de intervenção de urbanização de assentamentos precários cuja gestão e controle orçamentário se encontram sob a responsabilidade da Secretaria Nacional de Habitação, vieram prontas da Presidência, sem passar por qualquer discussão prévia junto ao Conselho das Cidades. Uma das críticas levantadas pelos movimentos sociais é que só uma pequena parte dos recursos destinados a esse tipo de intervenção foi alocada no FNHIS, que possui um conselho gestor pelo qual é possível estabelecer certo controle social sobre a destinação do dinheiro.
} 
Estes três aspectos - o fundiário, o financiamento habitacional e o arranjo institucional - por permearem e interferirem diretamente em nossa discussão, serão tratados de forma mais detalhada a seguir.

\subsubsection{Aspectos fundiários}

O atual quadro da situação fundiária no país tem raízes históricas em meados do século XIX (MARICATO, 1996) e apresenta efeitos negativos, ainda hoje, para efetivação do direto à moradia digna pautada pela Política Nacional de Habitação ${ }^{4}$. Isso porque o acesso à terra urbanizada e regularizada tem se tornado cada vez mais restrito à pequena parcela da brasileiros que consegue acessar a produção habitacional de mercado. A maior parte da produção habitacional do país se faz a margem do mercado formal, das leis, e em áreas rejeitadas pelo mercado imobiliário, entre elas as áreas ambientalmente frágeis e protegidas por lei (exemplo das áreas de manancial e de preservação permanente).

Com base no IBGE 2000 a presença de assentamentos irregulares se dava em quase a totalidade dos municípios com mais de 500 mil habitantes, e segundo os dados do Ministério das Cidades (BRASIL/MCID/SNPU, 2005) existiam em todo o país cerca de 12 milhões de domicílios com algum tipo de irregularidade fundiária, montante que representava quase 25\% do total de domicílios existentes em 2005.

A Secretaria Nacional de Programas Urbanos (SNPU) buscando interferir nesse cenário criou programas e campanhas que tinham como objetivo garantir o acesso democratizado à terra urbana regularizada e à moradia digna. A problemática fundiária que, até então, estava presente apenas nos programas voltados à urbanização de assentamentos precários, entrou na agenda da política urbana, com a criação do Programa Nacional de Regularização Fundiária - Papel Passado, voltado exclusivamente para tratar da matéria. Por meio desse programa entre 2003 e 2006 foram investidos cerca de R\$ 30 milhões de recursos do Orçamento Geral da União (OGU) transferidos aos municípios (BRASIL/MCID, 2008). Até novembro de 2006, as ações de regularização fundiária acompanhadas por esse

\footnotetext{
${ }^{4}$ Cf. MARICATO, Ermínia. Metrópole na periferia do capitalismo. São Paulo: Hucitec, 1996, que trata sobre o assunto e explicita a relação entre a Lei de Terras (1850) que atribuiu o valor de mercado à terra e restringiu o acesso à terra a um ínfima parcela da população antecipadamente ao processo abolição da escravidão e instituição do trabalho livre no Brasil.
} 
Programa envolveram 2.162 assentamentos em 283 municípios de 26 unidades da federação, o que representa 1.347.295 famílias com processo de regularização fundiária iniciado, das quais 300.334 receberam o título de posse ou propriedade do seu imóvel de moradia (BRASIL/MCID/SNPU, 2006).

Paralelamente, a SNPU tirando proveito de um momento em que cerca de 1.680 municípios do país tinham que cumprir a obrigatoriedade, definida no Estatuto das Cidades (Lei Federal no 10.257 de 2001) de elaboração de seus Planos Diretores até outubro de 2006, lançou a Campanha Nacional dos Planos Diretores Participativos. Seu objetivo foi fomentar, por meio de repasse de recurso, a elaboração participativa de Planos Diretores e, divulgar o papel e a importância dos instrumentos urbanísticos na garantia do direito à cidade, em especial ao cumprimento da função social da propriedade como meio de garantir o acesso à habitação digna às faixas de menor renda em detrimento da exclusão sócio-territorial.

Até fevereiro de 2007, com base em estudo realizado pelo CONFEA em convênio com o Ministério das Cidades, $44,62 \%$ do universo de 1.553 municípios pesquisados haviam aprovado seus Planos nas câmaras municipais, e um montante de 86,93\% dos Projetos de Lei dos Planos (somando os planos aprovados) tinham sido enviados às câmaras e se encontravam em processo de revisão e aprovação ${ }^{5}$. Apesar dos números relativamente positivos, não foi verificado qual a qualidade dos Planos desenvolvidos e o potencial de interferir positivamente no planejamento do uso e ocupação solo priorizando a democratização do acesso à terra urbana, um dos principais entraves para garantir a produção de habitação social ${ }^{6}$.

Ao lado disso, a SNPU passou a acompanhar também o processo de discussão do Projeto de Lei 3057 de 2000 que trata da revisão da Lei Federal de parcelamento do uso do solo urbano ( $\mathrm{n}$-6766 de 1979) e define as regras gerais que vão disciplinar o parcelamento do solo urbano e o processo de regularização fundiária sustentável, entre eles aqueles referentes a assentamentos de interesse social. Trata-se de uma proposta de lei ampla e

\footnotetext{
${ }^{5}$ Informações extraídas do site www.cidades.gov.br, acesso realizado em 20 de março de 2008.

${ }^{6}$ Atualmente está em elaboração por meio de convênio entre MCID/SNPU e o IPPUR-RJ um estudo de caráter mais qualitativo sobre os Planos Diretores. A instituição de determinados instrumentos urbanísticos como as ZEIS e outros indutores do parcelamento e edificação para fazer valer a função social da propriedade foram fundamentais, mas sabe-se que a efetivação desses instrumentos depende da vontade política do gestor público, que geralmente evita contrariar os interesses dos proprietários de terra.
} 
complexa que envolve diferentes interesses que percorrem desde a garantia do direto à cidade até aspectos referentes a atuação dos cartórios de registros de imóveis e aspectos do direito do consumidor, fato que tem dificultado a definição de consenso em torno do texto da lei e sua aprovação.

\subsubsection{Aspectos do financiamento habitacional}

Buscaremos abordar nos subitens a seguir algumas das principais medidas tomadas pelo Governo relacionadas com as diretrizes de investimento de recursos e de financiamento habitacional que passaram pela reorientação das aplicações de recursos do Sistema Financeiro de Habitação (FGTS e SBPE), pelo incentivo ao setor da construção civil, pela revisão das diretrizes dos programas habitacionais existentes, e também, pelo incremento do montante de recursos destinados, principalmente, às ações da política habitacional e de saneamento ambiental.

\subsubsection{Incentivo a atuação do mercado}

Entre os anos de 1990 e 2002, a média de financiamentos concedidos por meio do Sistema Brasileiro de Poupança e Empréstimos (SBPE) voltados às famílias de média renda restringiu-se em torno de $37 \mathrm{mil}$ financiamentos contratados ${ }^{7}$, número muito inferior aos patamares médios anuais desde 1966 que giraram na ordem de 85 mil financiamentos concedidos por ano (BRASIL/MCID, 2004). A classe média que apresenta capacidade financeira para acessar o mercado, sem dispor de financiamentos adequados passou a pleitear os recursos e subsídios oriundos do FGTS originalmente destinados as classes de menor renda.

Buscando corrigir a distorção de tal cenário foi firmado um pacto com o Conselho Monetário Nacional estabelecendo algumas medidas ${ }^{8}$ com o propósito de garantir maior

\footnotetext{
${ }^{7}$ Segundo BONDUKI (2008) embora os bancos estivessem obrigados por lei a realizar esse tipo de investimento, em função da crise da década de 80 , receberam a permissão para aplicar seus recursos em títulos da dívida pública, que rendiam muito mais.

${ }^{8}$ Expresso pela Lei no 10.931 de 2004 (que dispõe sobre patrimônio de afetação de incorporações imobiliárias), pela Lei o 11.033 de 2004 (que alteou a tributação do mercado financeiro e de capitais) e ainda pela Lei no 11.196 de 2005 (que entre a instituição de outras medidas dispõe sobre incentivos fiscais para inovação tecnológica).
} 
segurança jurídica e possibilitar a ampliação de investimentos no setor privado de moradias voltado à classe média. Reorientou-se as aplicações dos recursos do Sistema Financeiro de Habitação e incentivou-se uma maior atuação do mercado na produção habitacional de classe média. Somente no ano de 2007 cerca de R\$ 18,3 milhões do SBPE foram utilizados para viabilizar mais de 195 mil financiamentos (BRASIL/MCID, 2008:42).

Aliada a essas medidas, em 2006 o Governo promoveu outra série de ações buscando incentivar a atuação do setor privado na construção de novas habitações e beneficiar o segmento popular do mercado habitacional. Dentre as medidas destacamos (1) a redução do Imposto sobre Produtos Industrializados (IPI) com o propósito de baratear os preços de certos insumos e por conseqüência o custo da moradia $^{9}$; (2) a inclusão de empresas com receita bruta anual de até $\mathrm{R} \$$ 2,4 milhões na Lei Geral de Micro e Pequenas Empresas, levando a redução e simplificação da tributação sobre seus lucros e, consequentemente, rebatendo no valor ao consumidor final; e por fim, (3) incentivos a empresas que tomassem empréstimos juntos ao BNDES para buscar financiamento facilitado para construção ou aquisição de habitações próximas das próprias empresas (BRASIL/IPEA, 2007:286).

\subsubsection{Ampliação de recursos}

Entre 2003 e 2007 (conforme ilustrado pelo Gráfico 01) as operações financeiras destinadas ao atendimento habitacional alcançaram mais de $\mathrm{R} \$ 40$ bilhões de recursos onerosos - soma dos recursos do OGU, FGTS, FAT, FAR, FDS e CEF, somados a cerca de R\$ 9 bilhões de recursos não-onerosos - OGU e subsídios (BRASIL/MCID, 2008). Fato que significou um contínuo e significativo incremento de investimentos públicos no setor. E segundo Bonduki, essas

"transformações foram uma resposta às reivindicações dos movimentos de moradia, do setor empresarial da construção civil e de todos os segmentos que vinham lutando pela priorização dos investimentos nas políticas sociais" (2008:100).

\footnotetext{
${ }^{9}$ A redução de $10 \%$ para $5 \%$ sobre materiais de construção, como chuveiros, instalações sanitárias, caixa de descarga e outros, interferindo no preço dos insumos, e possivelmente, atingindo o custo da moradia produzida.
} 
Gráfico 01

Evolução do Investimento Federal em Habitação (2002 a 2007)

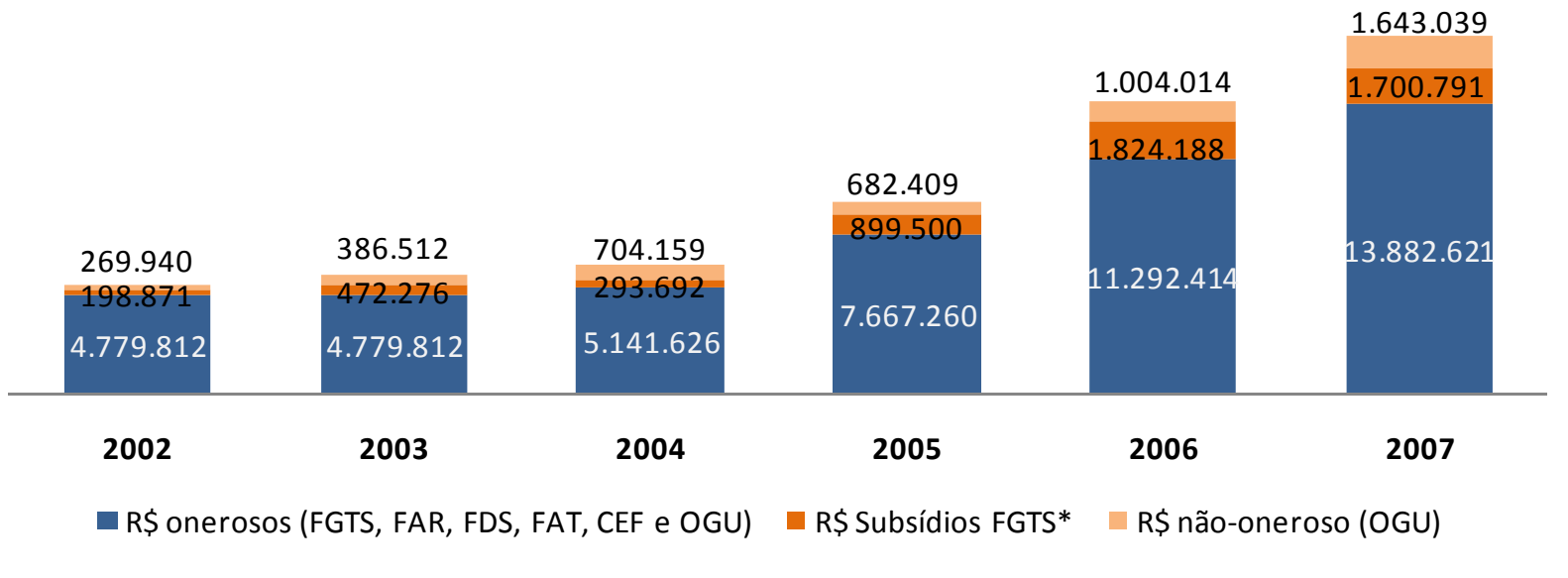

fonte: Ministério das Cidades e Relatório CEF. Posição 28/12/2007, disponível em www.cidades.gov.br

* subsídios oriundos da Res. 460/2004 do CCFGTS, a partir de 01/jun/2005.

A estabilidade macroeconômica aliada à desoneração da construção civil, às medidas que disponibilizaram crédito ao mercado privado e à continuidade de grandes investimentos públicos no setor habitacional e urbano contribuiram para o recente aquecimento do setor da construção civil $^{10}$. O crescimento pode ser verificado, com base nos dados do Cadastro Geral de Empregados e Desempregados (CAGED) do Ministério do Trabalho, pela geração de empregos formais pelo setor da construção civil quando em dez/2003 apresentava a defasagem de cerca de 48 mil vagas, em dez/2006 tinha contratado mais de 85 mil empregados e em dez/2007 mais de 176 mil vagas do setor estavam ocupadas ${ }^{11}$.

\footnotetext{
${ }^{10} \mathrm{O}$ aquecimento do setor da construção civil está diretamente ligado ao Programa de Aceleração do Crescimento (PAC) lançado em janeiro de 2007 pelo governo federal com o propósito de promover o crescimento do Produto Interno Bruto do país a partir de investimentos em obras de infra-estrutura, do estímulo ao acesso à crédito e financiamentos, e da melhoria das condições de investimento. O Programa foi dividido em três grandes eixos: logística, energia e, social e urbana. E em relação aos recursos destinados à habitação (urbanização de assentamentos precários), para o primeiro ano do programa foi previsto o investimento de $\mathrm{R} \$ 2,6$ bilhões oriundos do OGU. Até 2010 se estimou o investimento total de R\$11,1 bilhões para urbanização de assentamentos precários, (R\$ 8,3 bilhões de recursos não-onerosos e $\mathrm{R} \$ 2,8$ bilhões para financiamento) e ainda mais $R \$ 4$ bilhões de recursos destinados às ações do FNHIS.

${ }^{11}$ Os valores são referentes ao acumulado dos 12 meses de cada ano. Vale destacar que em setembro de 2008 o acumulado dos últimos 12 meses (entre set/2007 a set/2008) estava em 304 mil empregados, o que mostra comparado com o acumulado de dez/2008 (aproximadamente 197 mil) que os efeitos da crise econômica mundial passaram a atingir os setores da economia nacional a partir e outubro de 2008 (284 mil empregados).
} 
Gráfico 02

Evolução do emprego formal na construção civil (1999-2007)

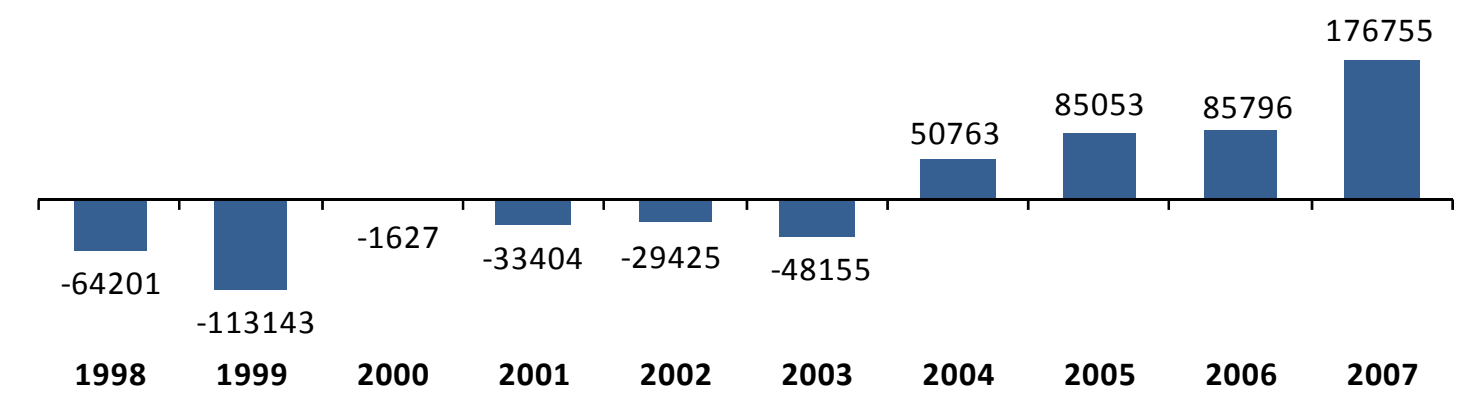

fonte: Ministério do Trabalho - GAED. Dados de referentes ao mês de dezembro de cada ano, disponível em www.mte.gov.br. Com base em Maricato (2006).

Sabe-se, no entanto, que o custo da moradia depende de vários fatores agregados, muitos deles definidos de forma especulativa (como o preço da terra). Nesse contexto, sem que o controle efetivo do mercado de terras e da cadeia produtiva seja feito, questionamos o quanto as medidas apresentadas acima poderiam de fato responder às suas motivações originais já que, ao invés de incentivar o barateamento do valor final da unidade habitacional, como se viu no final de 2007 até meados de 2008, resultou na valorização do mercado imobiliário, em especial, nas grandes cidades brasileiras.

Em função do aquecimento do mercado imobiliário que influencia diretamente a valorização da terra urbana, a produção de novos empreendimentos populares tem enfrentado grandes dificuldades para acessar o mercado de terra. Isso porque, esse tipo de empreendimento, na maioria das vezes, conta apenas com recursos disponíveis nos financiamentos de programas públicos para realizar a aquisição de terra, acarretando no baixíssimo poder de barganha e agilidade frente ao mercado privado.

Essa disputa desigual pelo acesso à terra, pautada pela lógica de mercado, não tem sido corrigida ou amenizada pelos instrumentos disponibilizados pelo Estatuto da Cidade ${ }^{12}$ em seus sete anos de vigência, nem com outro tipo de medida legal ou institucional do governo (descritas no item 3.1.1) que venha regular esse mercado e proteger a efetiva destinação das áreas de interesse social. Muito ainda há de ser feito para uma efetiva

\footnotetext{
${ }^{12}$ Apesar de representar um significativo avanço no marco institucional e legal brasileiro.
} 
concretização da função social da propriedade e quebra dos fortes paradigmas presentes na sociedade brasileira, em que o direito à propriedade vale mais do a necessidade de fazer cumprir seus direitos sociais.

\subsubsection{Ajuste do foco}

À medida que gerou maior impacto no enfrentamento da questão habitacional foi o redirecionamento do foco da ação estatal e a destinação dos recursos ao atendimento da real demanda, foco do déficit habitacional ${ }^{13}$. Apesar da aparente continuidade do modelo do Sistema Financeiro da Habitação, que se perpetuou como a principal fonte de recurso da política habitacional do país, ocorreu uma forte reorientação dos subsídios aplicados aos programas habitacionais, a partir da Resolução no 460 de 2004 e, posterior alteração pela Resolução no 518 de 2006 do Conselho Curador do FGTS, que proporcionou altos subsídios diretos distribuídos proporcionalmente às faixas de menor renda aos financiamentos concedidos pelas Operações Coletivas - Cartas de Crédito Individual.

\section{Gráfico 3}

\section{Distribuição de subsídios do FGTS por faixa de renda}

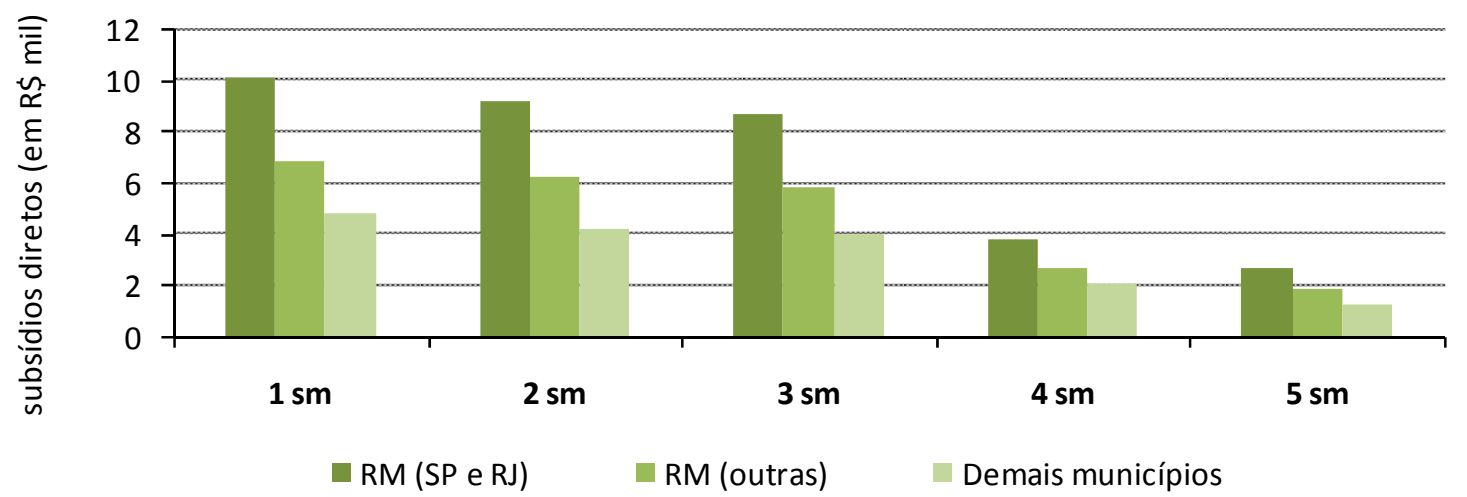

fonte: Medeiros, 2007. Dados: simulador da CEF, disponível em www.caixa.gov.br

1: Municípios integrantes das regiões metropolitanas dos estados do Rio de Janeiro e São Paulo.

2: Municípios integrantes de regiões metropolitanas, áreas conurbadas ou aglomerados urbanos, municipios sede de capitais estaduais ou com população igual ou superior a cem mil habitantes.

3: Demias municípios.

\footnotetext{
${ }^{13}$ As famílias até cinco salários mínimos representam $96 \%$ do déficit habitacional, e o universo de famílias com renda inferior a três salários mínimos representa $90 \%$ do total, conforme ilustrado pelo Tabela 5 (p. 78) do capítulo anterior.
} 
Criou-se no governo federal uma política de subsídios inversamente proporcional a renda familiar que possibilitou ao longo dos últimos anos viabilizar o atendimento das famílias com renda inferior a cinco salários mínimos, conforme ilustra o Gráfico 04.

\section{Gráfico 04}

Percentual de atendimentos habitacionais com recursos do FGTS por faixa de renda (2002-2007)

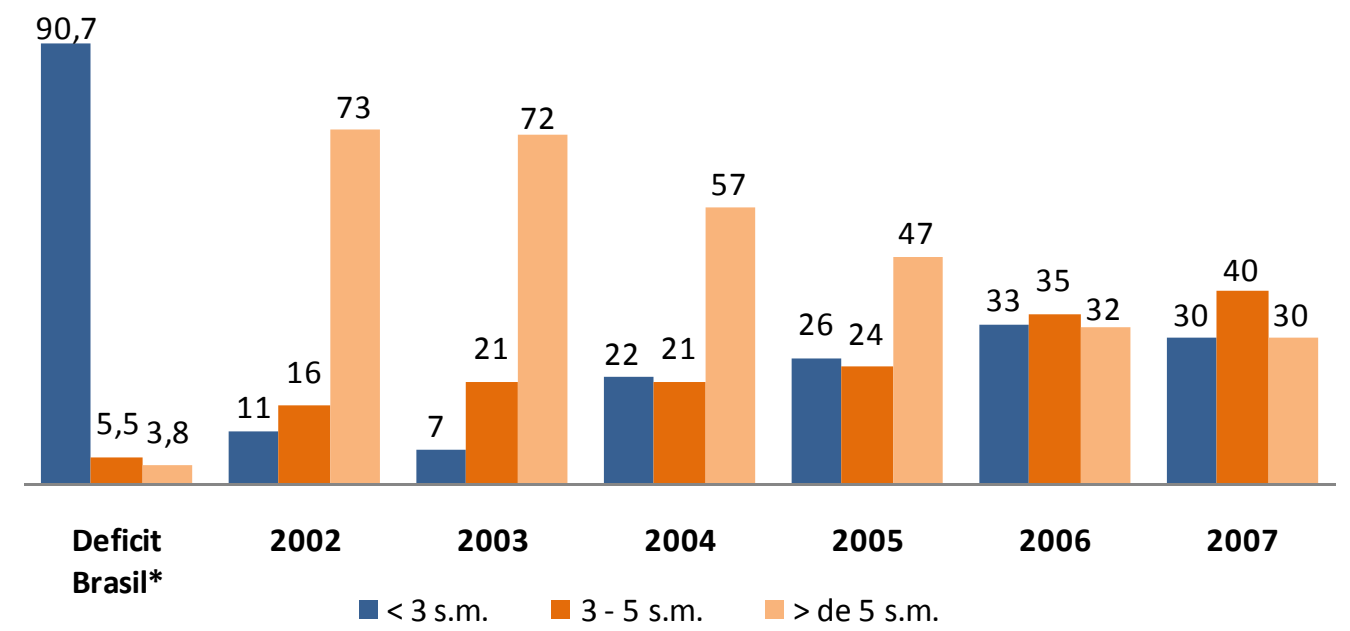

fonte: BRASIL/MCID/SNH, 2008.

*Deficit Habitacional no Brasil 2006 (FJP, 2008).

Apesar desta importante inversão de prioridade na aplicação dos subsídios dos recursos do FGTS e demais recursos onerosos (como FAT, FAR, FDS e CAIXA) em relação às ações habitacionais anteriores, e dos positivos resultados quantitativos da ação pública federal, ainda não foi avaliado, nem mesmo em linhas gerais, qual a feição (qualidade) dessas ações habitacionais ${ }^{14}$.

\subsubsection{Rearranjo institucional}

A diretriz inicial tomada pelo Ministério das Cidades foi "... encaminhar a formulação da política nacional de desenvolvimento urbano e das políticas setoriais sem paralisar as ações em andamento e se possível aperfeiçoando-as." Tratava-se então, de um longo momento de transição, que tinha como meta transformar um “... conjunto de ações

\footnotetext{
${ }^{14}$ Um estudo sobre a qualidade desses atendimentos seria de grande importância, pois não foram encontradas muitas imagens referentes à divulgação do que se tem produzido com os recursos desses financiamentos.
} 
dispersas para um conjunto de ações coerentes e complementares pactuadas com os entes federativos e a sociedade" (BRASIL/MCID, 2004b:7).

\section{Quadro 01}

Resumo dos programas federais - aquisição e produção - de HIS (2008)

\begin{tabular}{|c|c|c|c|c|c|c|c|c|}
\hline Programas & $\begin{array}{l}\text { Fonte de } \\
\text { Recursos }\end{array}$ & Proponentes & $\begin{array}{l}\text { Público Alvo } \\
\text { por renda }\end{array}$ & $\begin{array}{c}\text { Valor máximo } \\
\text { do } \\
\text { financiamento }\end{array}$ & $\begin{array}{c}\text { Prazo máximo } \\
\text { de } \\
\text { financiamento }\end{array}$ & $\begin{array}{l}\text { Contrapartida } \\
\text { mínima do } \\
\text { beneficiários }\end{array}$ & $\begin{array}{c}\text { Correção } \\
\text { Monetária } \\
\text { Referencial }\end{array}$ & $\begin{array}{c}\text { Juros sobre } \\
\text { o saldo } \\
\text { devedor }\end{array}$ \\
\hline $\begin{array}{l}\text { Carta de Crédito } \\
\text { Individual }\end{array}$ & FGTS & pessoas físicas & $\begin{array}{c}<\mathrm{R} \$ 3.900,00 \\
*\end{array}$ & $\begin{array}{l}\mathrm{R} \$ 130.000,00 \\
* *\end{array}$ & 20 anos & $5 \%-7,5 \%$ & $\mathrm{TR}$ & $6 \%-8 \%$ \\
\hline $\begin{array}{c}\text { Carta de Crédito } \\
\text { Associativa }\end{array}$ & FGTS & $\begin{array}{l}\text { pessoas físicas } \\
\text { organizadas em } \\
\text { entidades } \\
\text { associativas }\end{array}$ & $\begin{array}{l}<\mathrm{R} \$ 3.900,00 \\
*\end{array}$ & $\begin{array}{l}\mathrm{R} \$ 130.000,00 \\
* *\end{array}$ & 20 anos & $5 \%-7,5 \%$ & $\mathrm{TR}$ & $6 \%-8 \%$ \\
\hline $\begin{array}{l}\text { Desconto FGTS } \\
\text { (Res.460) }\end{array}$ & FGTS & $\begin{array}{c}\text { pessoas físicas } \\
\text { organizadas (ou } \\
\text { não) em entidades } \\
\text { associativas }\end{array}$ & $\begin{array}{l}<\mathrm{R} \$ 1.750,00 \\
*\end{array}$ & $\begin{array}{c}\text { subsídio } \\
\text { máximo de } \\
\mathrm{R} \$ 14.000,00\end{array}$ & \multicolumn{4}{|c|}{$\begin{array}{l}\text { subsídio ofertado em conjunto com financiamentos dos } \\
\text { programas Carta de Crédito. }\end{array}$} \\
\hline $\begin{array}{c}\text { Programa de } \\
\text { Arrendamento } \\
\text { Residencial - PAR }\end{array}$ & FAR & $\begin{array}{l}\text { pessoas juridicas na } \\
\text { construção e } \\
\text { pessoas fisicas no } \\
\text { arrendamento }\end{array}$ & $<R \$ 2.400,00$ & $\mathrm{R} \$ 40.000,00$ & 15 anos & não tem & $\begin{array}{c}\text { TR- } \\
\text { prestação } \\
\text { de } 80 \% \text { e TR- } \\
\text { saldo } \\
\text { devedor }\end{array}$ & $5-7 \%$ \\
\hline $\begin{array}{l}\text { Programa de } \\
\text { Subsídio à } \\
\text { Habitação - PSH }\end{array}$ & OGU & $\begin{array}{c}\text { governos locais e } \\
\text { depois pessoas } \\
\text { físicas }\end{array}$ & $<R \$ 1.114,00$ & $\mathrm{R} \$ 10.000,00$ & 6 anos & não tem & $\mathrm{TR}$ & $6 \%$ \\
\hline $\begin{array}{c}\text { Programa } \\
\text { Crédito } \\
\text { Solidários - PCS }\end{array}$ & FDS & $\begin{array}{c}\text { pessoas físicas } \\
\text { organizadas em } \\
\text { entidades } \\
\text { associativas }\end{array}$ & $\begin{array}{l}<\mathrm{R} \$ 1.900,00 \\
* * *\end{array}$ & $\mathrm{R} \$ 30.000,00 * *$ & 20 anos & $5 \%$ & $\mathrm{TR}$ & zero \\
\hline $\begin{array}{l}\text { Apoio à Provisão } \\
\text { Habitacional }\end{array}$ & FNHIS & $\begin{array}{c}\text { governos locais e } \\
\text { depois pessoas } \\
\text { físicas }\end{array}$ & $<R \$ 1.050,00$ & $\mathrm{R} \$ 23.000,00$ & \multicolumn{4}{|c|}{$\begin{array}{l}\text { por tratar-se de repasse direto ao poder público local, cabe a } \\
\text { ele definir as condições de retorno do recurso. }\end{array}$} \\
\hline $\begin{array}{c}\text { Apoio à Podução } \\
\text { Social da } \\
\text { Moradia - PSM }\end{array}$ & FNHIS & $\begin{array}{c}\text { pessoas físicas } \\
\text { organizadas em } \\
\text { entidades } \\
\text { associativas }\end{array}$ & $<\mathrm{R} \$ 1.125,00$ & $\mathrm{R} \$ 30.000,00 * *$ & 12 anos & $1 \%$ & $\mathrm{TR}$ & zero \\
\hline
\end{tabular}

fonte: Ministério das Cidades (disponível em www.cidades.gov.br, acesso 10.02.2008) e Caixa Econômica Federal (disponivel em www.caixa.gov.br, acesso 10.02.2008)

* Os limites de renda altera em função das modalidades.

** Os limites de financiamento máximo varia em função das características das cidades (RMs, Ride -DF, a cima de 100 mil habitantes, e demais municípios).

***É permitido o atendimento de até 35\% de famílias com renda entre 3sm e 5sm, no caso das RMs.

Confirmando essa diretriz, as alterações dos programas habitacionais têm ocorrido lentamente, segundo Bonduki "notando uma certa dificuldade em abandonar os modelos estruturados no governo FHC" (2008:99). Os programas Carta de Crédito Individual, Carta de Crédito Associativo, Apoio à Produção de Habitação e o Pró-Moradia (que utilizam recursos do FGTS), o Programa de Arrendamento Residencial (que utiliza recurso do FAR), bem como 
os programas Habitar-Brasil/BID, PSH (Programa de Subsídio Habitacional) e PBQP-H (que utilizam os recursos do OGU) continuam sendo operados. Entretanto, todos eles passaram por alterações, respondendo as diretrizes de inversão de prioridade de atendimento e direcionamento de subsídios, e ainda passaram por incremento de investimentos, conforme apresentado anteriormente. O único novo programa criado neste governo foi o Crédito Solidário, voltado às associações e movimentos de moradia, que será tratado com detalhes a seguir.

Simultaneamente aos ajustes propostos aos programas, iniciou-se a reestruturação institucional e legal do setor habitacional, buscando em um horizonte de longo prazo a consolidação de uma Política Nacional de Habitação articulada, sustentável e contínua a partir da viabilização do a) Sistema Nacional de Habitação, b) do desenvolvimento institucional do setor, c) do Sistema de Informação, Avaliação e Monitoramento da Habitação e d) do Plano Nacional de Habitação (BRASIL/MCID, 2004).

Entretanto podemos observar que nos dois primeiros anos a agenda da Reforma Urbana que orientou a criação do Ministério das Cidades foi perdendo força. E, após a reeleição do Presidente Lula em 2006 o Ministério das Cidades, já sob a comando do ministro Marcio Fortes, em detrimento do positivo trabalho que vinha sendo realizado a pequenos passos em direção à Reforma Urbana, passou por uma (des)estruturação e mudança do comando e das diretrizes de três das Secretarias Nacionais: Saneamento Ambiental, Transporte e Mobilidade, e Programas Urbanos.

A partir de então a história novamente se repete ${ }^{15}$ e as diretrizes que apontavam para a integração das ações setoriais da política urbana e da construção de uma Política Nacional de Desenvolvimento Urbano de longo prazo foram preteridas em prol dos acordos políticos e da governabilidade. A Secretaria Nacional da Habitação permaneceu como estava e pôde levar adiante a estruturação institucional já em andamento.

\footnotetext{
${ }^{15}$ As diretrizes do BNH se sobrepuseram ao SERFHAU (Serviço Federal de Habitação e Urbanismo, criado em 1964) e ao CNDU (Conselho Nacional de Desenvolvimento Urbano). O mesmo aconteceu quando a CEF, após extinção do $\mathrm{BNH}$, orientou as diretrizes da ação governamental ofuscando o papel a ser desempenhado pela Secretaria de Política Urbana (SEPURB, criada em 1995 e ligada ao Ministério do Planejamento) e posteriormente pela SEDU/PR (Secretaria Especial de Desenvolvimento Urbana ligada a Presidência da República).
} 


\subsubsection{Sistema e o Fundo Nacional de Habitação de Interesse Social}

$\mathrm{Na}$ 1a Conferência das Cidades realizada em 2003, uma das recomendações aprovadas foi a imediata retomada do processo de aprovação do Projeto de Lei do FNMP, citado inclusive pelo Presidente em seu discurso de abertura:

"Quero falar sobre o projeto de lei (...) do Fundo Nacional de Moradia Popular. Este projeto está há 12 anos tramitando na Câmara, já recebeu um monte de modificações, já recebeu um monte de emendas, já recebeu um monte de coisas. Eu disse ao companheiro João Paulo que nós vamos ter que tirar este projeto... Possivelmente aqui vocês tratem de propor aperfeiçoamento naquilo que foi feito há 12 anos, e vamos ter que votar esse projeto, porque eu não quero esquecer tudo que fiz e escrevi no meu passado e fui consignatário desse projeto de lei." (Presidente Lula, em 23 de outubro de 2003)

Entre 2003 e 2005 a área econômica do governo apontou inúmeras restrições ao PL do FNMP, apesar do apoio público demonstrado pelo presidente. Isso porque, segundo Bonduki (2008), esse grupo do governo costuma ser avesso à criação de fundos, pois esses passam a restringir a margem de manobra da gestão do orçamento público. Somados a isso, "a existência do fundo pressupõe, embora não garanta, a alocação de parcelas significativas do orçamento para fins de subsídio, o que contrariava a política de criação de superávit primário" (BONDUKI, 2008:98) encampada pelo governo.

Depois de muita discussão que resultou na reformulação da proposta, foi encaminhado ao Congresso um substitutivo, onde a dimensão da política habitacional ficou limitada, pois deixou de tratar do sistema financeiro da habitação de forma global, remetendo apenas ao Subsistema de Interesse Social. Em junho de 2005 a Lei Federal no 11.124, que institui o Fundo Nacional de Habitação de Interesse Social - FNHIS e o Sistema Nacional de Habitação de Interesse Social - SNHIS foi aprovada.

"Perdemos muito da proposta original... Uma das perdas da proposta foi exatamente essa... Hoje, ele (FNHIS) só recebe recurso não-oneroso." (Evaniza Rodrigues, 27.02.2008)

Na proposta original se previa a combinação de recursos onerosos e não-onerosos o que aumentava o potencial de suas intervenções. Outra perda significativa, especialmente 
para o movimento popular, foi a eliminação da proposta que admitia as associações e cooperativas como possíveis agentes promotores dos programas habitacionais, garantindo a elas o direito de gerirem recursos do fundo público e promoverem habitação por meio da autogestão.

A possibilidade do repasse direto dos recursos do FNHIS para entidades privadas sem fins lucrativos foi aprovada somente dois anos depois, quando a Lei Federal no 11.578 de 2007 foi sancionada após longas discussões e pressão dos movimentos populares junto ao Governo. Em março de 2008, em decorrência de muita negociação no CGFNHIS foi aprovada a ação Produção Social da Moradia e destinados $\mathrm{R} \$ 100$ milhões para produção habitacional autogerida, entretanto, o processo de implementação dessa ação tem sido muito moroso ${ }^{16}$. Após quase um ano da criação dessa ação, o processo encontra-se ainda em fase de recebimento das Cartas Consultas encaminhadas pelas entidades para análise do Ministério das Cidades.

Apesar das distorções em relação ao PL original, a aprovação do SNHIS/FNHIS significou a conquista de um importante mecanismo que permite atribuir à questão habitacional maior perenidade, já que seu objetivo é articular as políticas de Habitação de Interesse Social em um sistema federativo, que pressupõe a descentralização, o controle social, a transparência dos procedimentos decisórios e, portanto, a participação democrática.

Em médio prazo, para que o Subsistema de Habitação de Interesses Social funcione plenamente, estão previstas as criações dos fundos estaduais e municipais de habitação e seus conselhos gestores deliberativos, bem como formulação dos planos estaduais e municipais de habitação, alinhados ao Plano Nacional de Habitação (PLANHAB), atualmente em processo de conclusão ${ }^{17}$. Os Planos (municipais e estaduais) deverão estabelecer metas,

\footnotetext{
${ }^{16} \mathrm{Em} 19$ de maio foi aberto o processo de habilitação das entidades sem fins lucrativos interessadas em acessar os recursos da ação Produção Social da Moradia (PSM). Em junho de 2008 esse processo foi temporariamente suspenso, no final do mesmo ano foi reaberto o processo de reabilitação das entidades. Após a divulgação da lista de entidades aptas, até fim de fevereiro de 2009 deveriam ser entregues as Cartas Consultas das propostas ao Ministério das Cidades.

${ }^{17}$ O PLANHAB é outro importante instrumento de planejamento e orientador da ação estatal (nas três esferas), articulada com setor privado para enfrentar o déficit habitacional atual e responder às necessidades habitacionais futuras. Nele foram definidos o tamanho das necessidades habitacionais, diretrizes, objetivos, metas, linhas de ações, recursos necessários, entre outros aspectos, para tratar de maneira adequada o nó habitacional do país no horizonte temporal até 2023 (articulados com os Planos Plurianuais), considerando a diversidade regional do país.
} 
diretrizes e outras medidas articuladas ao planejamento territorial de uso e ocupação do solo e aspectos ambientais, que nortearão o uso dos recursos de seus Fundos e oriundos dos repasses do FNHIS. Trata-se, assim, de um importante passo rumo à estruturação de um novo arranjo institucional do Sistema Nacional de Habitação ${ }^{18}$ e da efetivação da Política Nacional de Habitação.

Alimentado por recursos não-onerosos do OGU, FGTS, FAT e outros, o FNHIS recebeu no primeiro ano de exercício (2006) um orçamento de $R \$ 1$ bilhão que foi aplicado às intervenções para erradicação de palafitas sem discussão de critérios. Essa definição foi feita por indicação direta do Presidente da República porque até então o conselho gestor do fundo não tinha sido instituído. Somente após um ano de criação do FNHIS, foi aprovado o Decreto no 5.796 de junho de 2006 que regulamentou o SNHIS/ FNHIS e instituiu o Conselho Gestor do Fundo de Habitação de Interesse Social (CGFNHIS).

A partir de $2007^{19}$, o Conselho Gestor do FNHIS passa a funcionar e deliberar sobre a utilização dos recursos do fundo, e entre outras atribuições, passa a monitorar o uso desses recursos aplicados por meio de programas e linhas de ações similares as ações de repasse de recursos oferecidas anteriormente pelas sistemáticas do $\mathrm{OGU}^{20}$ :

- Programa de Urbanização, Regularização e Integração de Assentamentos Precários;

- Programa de Habitação de Interesse Social - HIS ;

- Ação Provisão Habitacional de Interesse Social, divididas nas seguintes modalidades:

- Produção ou Aquisição de Unidades Habitacionais;

- Produção ou Aquisição de Lotes Urbanizados;

- Requalificação de Imóveis;

\footnotetext{
${ }^{18}$ A proposta do Sistema Nacional de Habitação está dividida em dois subsistemas: Habitação de Interesses Social e Habitação de Mercado, e tem como base a estruturação do arranjo institucional apoiado na relação integrada entre os três entes federativos e agentes privados, devendo definir regras de articulação financeira necessárias para a implementação da Política Nacional de Habitação.

${ }^{19}$ Com o lançamento do PAC neste mesmo ano, foram previstos no PPA (2007-2010) a destinação de R\$ 4 bilhões ao FNHIS até 2010.

${ }^{20}$ Os recursos do OGU que não compõe o FNHIS estão atualmente voltados aos programas Habitar Brasil/BID em processo de conclusão, Programa Brasileiro da Qualidade e Produtividade do Habitat - PBQP-H, Programa de Subsídio à Habitação de Interesse Social - PSH e ainda, às ações do PAC.
} 
- Assistência Técnica

- Ação Apoio à elaboração de Planos Locais de Habitação de Interesse Social - PLHIS;

- Ação Apoio à Produção Social da Moradia - PMS.

\subsection{Velhas idéias em outro contexto: 0 Programa Crédito Solidário}

"O Crédito (Solidário), então, é um programa ponte entre a situação em que o governo (Lula) entra até a aprovação do Fundo (FNHIS), o que a princípio redireciona uma alteração total da política." (Evaniza Rodrigues, 27.02.2008).

\subsubsection{O Fundo de Desenvolvimento Social e o Conselho Curador do FDS}

Em 1991, ainda no Governo Itamar Franco, o Fundo de Desenvolvimento Social (FDS) de natureza contábil foi criado ${ }^{21}$ para financiar exclusivamente ao setor privado projetos de investimentos de interesse social nas áreas de habitação popular, saneamento básico, infraestrutura urbana e equipamentos comunitários. Seus recursos foram constituídos por aquisições compulsórias e voluntárias de suas cotas, por entidades financeiras, emitidas pelos Fundos de Aplicação Financeira (FAF) e pelo resultado de suas aplicações. O Conselho Curador do FDS (CCFDS) ${ }^{22}$ foi criado para realizar sua gestão, sendo responsável por definir diretrizes para concessão de crédito, desenhos operacionais de financiamento e respectivo retorno, acompanhamento e controle dos andamentos dos financiamentos, entre outras atribuições.

Apesar de termos identificado a circular interna da CEF no 10 de dezembro de 1991 que definia orientações operacionais para os financiamentos com recursos do FDS

\footnotetext{
${ }^{21}$ Decreto n103 de 22 de abril de 1991, ainda no Governo Collor e posteriormente aprovado pela Lei Federal no 8.677 de 13 de julho de 1993, no Governo Itamar Franco.

${ }^{22}$ Pela Lei Federal no 8.677 de 1993, o CCFDS deveria ser composto por 11 membros: 5 representantes do Governo Federal (1 do Ministério do Bem Estar Social, 1 do Ministério da Fazenda, 1 do Ministério do Planejamento, 1 da CEF, e do BACEN), 3 representantes da categoria dos empregadores (1 da Confederação Nacional das Instituições Financeiras, 1 da Confederação Nacional do Comércio e 1 da Confederação Nacional da Indústria) e mais 3 representantes da categoria dos trabalhadores (1 da Confederação Geral dos Trabalhadores, 1 da Central Única dos Trabalhadores, e 1 da Força Sindical).
} 
destinados a produção da "Habitação do Trabalhador" ${ }^{23}$, estes nunca foram utilizados e o fundo permaneceu inativo ao longo dos anos 90.

Segundo Cesar Ramos ${ }^{24}$, coordenador do Programa Crédito Solidário no Ministério das Cidades, a partir de 1996 em função do PROER ${ }^{25}$, surgiram diversos questionamentos em relação à devolução dos recursos do fundo às instituições financeiras e como deveriam ser calculados os valores a serem resgatados. Porém, nem mesmo se sabia se os bancos tinham tido lucro ou prejuízo e como comprovar tal fato. O CCFDS elaborou então, uma resolução que orientava o resgate das cotas a qual os bancos não aceitaram, e a partir de então o FDS ficou parado, sem receber novos recursos.

Em 1998, cerca de R\$ 1,5 bilhões foram retirados do FDS para compor o Fundo de Arrendamento Residencial (FAR) em função da criação do Programa de Arrendamento Residencial (PAR) pelo Ministério do Planejamento, então responsável por formular e coordenar as Políticas Nacionais de Desenvolvimento Urbano e Habitação e ocupante da presidência do CCFDS.

Esses episódios mostraram que o FDS não representava uma fonte de recursos significativa que atendesse às diretrizes de atuação dos governos subseqüentes a sua criação. Entre 1999 e 2001, o Conselho Curador ficou sem se reunir pela falta de indicação de nomes para a recomposição de representantes governamentais após a criação da Secretaria Especial de Desenvolvimento Urbano da Presidência da República (SEDU/PR). Somente em setembro de 2001 foi aprovado um novo decreto ${ }^{26}$ que determina a nova composição do CCFDS, após a divulgação de informativo elaborado por um técnico da SEDU/PR, que chamava a atenção sobre a imobilidade das ações do FDS e destacava o importante papel que seus recursos poderiam desempenhar para tornar viáveis as

\footnotetext{
${ }^{23}$ Nesta circular interna foram definidos critérios para as solicitações de financiamentos com recursos do FDS para projetos de interesse social nas áreas de habitação popular (áreas urbanas e rurais), saneamento e equipamento comunitário. O programa Habitação do trabalhador foi destinado a famílias com até 5 salários mínimos. Os investimentos poderiam ser destinados a projetos, aquisição de terreno, construção e para o pagamento da taxa de risco de crédito. O valor máximo por unidade foi definido em 1.800 UPF (em Nov/1991).

${ }^{24}$ Entrevista realizada com César Ramos - coordenador do Programa Crédito Solidário, Ministério das Cidades em 13 de fevereiro de 2008.

${ }^{25}$ O PROER (Programa de Estímulo à Reestruturação e ao Fortalecimento do Sistema Financeiro Nacional) foi um programa criado em 1995 objetivando recuperar as instituições financeiras que estivessem com problemas financeiros e evitar colapso econômico no período em que o mundo sofria com a crise econômica asiática.

${ }^{26}$ Decreto no 3.907 de 04 de setembro de 2001.
} 
operações de Cartas de Crédito (do FGTS) às famílias de menor renda, subsidiando parte dos encargos cobrados nos financiamentos.

Somente em 2002 o CCFDS volta a se reunir, no momento em que o Tribunal de Contas da União (TCU) cobrou da CEF o porquê da não aplicação dos recursos do FDS. A partir de então, diversas propostas de utilização dos recursos do fundo foram debatidas internamente ao CCFDS sem avançar em resultados concretos.

Em 2003, quando o Ministério das Cidades foi criado e passou a presidir e ter representantes no CCFDS, segundo o relato da gerente dos Fundos de Governo da CEF e Conselheira do FDS Cláudia Gomes ${ }^{27}$, a CEF apresentou a proposta de um programa para atendimento habitacional destinado às cooperativas de produção, que poderiam oferecer mais garantias ao crédito financiado, justamente por já exercerem uma atividade econômica.

Questionada, em entrevista, se alguma experiência anterior de outros programas municipais, estaduais, ou mesmo de outros países, tinha servido como referência para a formulação dessa proposta, Gomes afirmou que o único programa destinado a cooperativas habitacionais (INOCOOP) que conhecia era da época do BNH. E, por ter sido uma experiência negativa, pois ainda hoje se paga pelas dívidas deixadas por elas junto ao $\mathrm{FCVS}^{28}$, relutava em propor um programa que tivesse como interlocutoras as cooperativas habitacionais.

Apesar das resistências, a CEF resolveu apresentar o programa já que os recursos eram limitados se comparados com a atuação da instituição como um todo, oferecendo a ela baixos prejuízos caso não desse certo:

“...ah, RS 500 milhões não é nada. Vamos abrir um programa assim, com cooperativas, elas têm atividade econômica e querem construir empreendimentos para seus cooperados..." (Cláudia Gomes, 24.03.2008).

Gomes relatou ainda, que até então, as propostas do movimento de moradia não eram de conhecimento da CEF, mais surpreendente é a afirmação: "Da nossa parte não

\footnotetext{
${ }^{27}$ Entrevista realizada com Cláudia Gomes, gerente dos Fundos de Governo da CEF, em 24 de março de 2008.

${ }^{28}$ O FUNDO DE COMPENSAÇÃO DOS VALORES SALARIAIS (FCVS) foi criado ainda no final dos anos do BNH, em período de altas inflacionárias, com o propósito de absorver os saldos devedores dos financiamentos. Com a extinção do BNH a CEF ficou responsável pela gestão desse fundo.
} 
conhecia essa parte dos movimentos. Essa figura pra mim não existia, quando a gente estava criando o programa."(Cláudia Gomes, 24.03.2008).

Foi por intermédio de representantes do Ministério das Cidades que o pleito do movimento popular foi sendo introduzido a cada nova reunião do CCFDS, influenciando na formulação do programa Crédito Solidário consolidado pela Resolução no 93 de 2004, após diversas precificações realizadas pela CEF e o aval, não sem resistências de determinados membros do CCFDS como veremos a seguir ${ }^{29}$.

O Programa Crédito Solidário surge assim, como um programa social de habitação, sustentado pelo movimento popular e viabilizado por recursos privados ${ }^{30}$ de um fundo secundário, cujo desenho operacional foi formulado pela CEF, agente operadora ${ }^{31}$ dos recursos do FDS, e a ser operacionalizado por um banco (agente financeiro).

Qual o significado e as implicações decorrentes desse arranjo?

\subsubsection{A criação do Programa Crédito Solidário}

"O objetivo do programa não é construir casa, é construir cidadania junto com a casa (...) Mas isso é discutível... Na prática e na teoria". (Cesar Ramos, 13.02.2008)

O Programa Crédito Solidário foi criado em abril de 2004 em decorrência da reivindicação das quatro entidades nacionais UNMP, MNLM, CONAM e CMP para formulação de um programa que priorizasse o atendimento habitacional às famílias com renda inferior a três salários mínimos e que estivesse apoiado nas bases do cooperativismo e associativismo com o propósito de fortalecer as práticas autogestionárias e da organização popular (FNRU, 2004).

\footnotetext{
${ }^{29}$ Atualmente o CCFDS é presidido pelo representante do Ministério das Cidades, e é composto por um secretário executivo, também do Ministério das Cidades, um representante do Ministério da Fazenda, um do Planejamento, um do Ministério do Desenvolvimento Social. Mais um representante da CEF, um do BACEN, e um da FEBRABAN. Um representante da CNF, da CNC e CNI. E por fim, um representante de cada uma das organizações dos trabalhadores: a CUT, a CGP, a FS e SDS. Vale destacar que não existe no CCFDS vaga de representação aos movimentos de moradia.

${ }^{30}$ Hoje, 70\% dos recursos que compõe o FDS são privados e cerca de $30 \%$ são do próprio fundo.

${ }^{31}$ O Agente Operador, no caso a CEF (como Banco de primeira linha) é responsável pela gestão dos recursos dos fundos (FGTS, FDS, outros). Seu papel é financiar os recursos dos fundos para os Agentes Financeiros que são os bancos comerciais (denominados Bancos de segunda linha) que operam os financiamentos junto aos beneficiários finais.
} 
Essa antiga reivindicação junto à esfera federal, conforme apresentado no capítulo anterior, nasce inicialmente da experiência do Funaps-Comunitário no município de São Paulo (1989-1992) e se fez presente ao longo dos anos 90 nas pautas levadas pelo movimento de moradia ao governo federal. Desde as primeiras caravanas à Brasília as respostas do Estado se restringiram a projetos pilotos viabilizadas com recursos do FGTS a partir de protótipos de programas habitacionais autogestionários ${ }^{32}$, e que apesar de bem avaliados, não foram transformados em programas.

O movimento de moradia buscou outros caminhos, como as iniciativas de articulação com representações sindicais com cadeira nos conselhos do FGTS e FDS (especialmente com a CUT), com o propósito de convencê-las da importância da proposta de produção habitacional por meio da autogestão a ser apresentada e defendida por elas nos Conselhos Curadores desses fundos (BARBOSA, apud SILVA, 1994: 75).

Foram iniciativas que não surtiram efeitos concretos e que justificavam a ponderação levantada pelos representantes da UNMP:

"Uma mistura de preconceito com contrariedade a interesses políticos e/ou econômicos tem feito com que os movimentos populares estejam sempre obrigados a 'provar' sua capacidade e integridade para gerir os recursos públicos para a produção de sua moradia." (RODRIGUES, PESSINA e BARBOSA, 2008:22)

Quando o Ministério das Cidades, ainda no primeiro ano de gestão, assume o compromisso de elaborar um programa nesses moldes, o movimento de moradia, expresso por Rodrigues (2008), mesmo ciente de que seria um programa com data para acabar (pois seus recursos eram poucos e finitos) encarou a conquista do Crédito Solidário como uma grande vitória.

Enquanto o Projeto de Lei do Fundo Nacional de Moradia voltava a tramitar no Congresso e até a sua aprovação, o PCS desempenharia importante papel de difundir às famílias de baixa renda dos mais diferentes territórios brasileiros a possibilidade de vivenciar na prática um processo autogerido de produção habitacional.

\footnotetext{
${ }^{32}$ As experiências ocorridas em Diadema e Santo André com recursos do FGTS nos governos Sarney e Collor, citadas no capítulo 02.
} 
Porém, os princípios que permeavam a proposta do movimento apresentavam novidades que se distanciavam dos modelos tradicionais dos programas federais geridos pela $C E F$, e não agradaram o governo como um todo, sendo questionados a credibilidade e o bom funcionamento do novo programa. Buscando enfrentar menor resistência e encampar a idéia optou-se segundo Ramos ${ }^{33}$, por utilizar os recursos do FDS (um fundo que não chamava atenção dos governos anteriores e que estava parado há mais de uma década) abrindo mão do FGTS, principal fundo destinado à política habitacional.

A avaliação de Pessina a respeito da utilização do FDS foi a de que os representantes do Ministério das Cidades ao proporem o programa tinham uma idéia de algo mais artesanal e experimental pautado em,

“... pequenos valores para (municípios do) interior... com $R \$ 5.000,00$. Achavam que a assessoria técnica não precisava ser remunerada, que poderia conseguir na universidade... um mutirão artesanal, sem muito apoio, e não uma coisa institucionalizada e profissional que fizemos em São Paulo." (Leonardo Pessina, 19.03.2008).

Mesmo utilizando um fundo secundário, de menor importância financeira, o representante do Banco Central no momento do debate para a aprovação do programa junto ao CCFDS se retirou alegando que a proposta rompia com as regras de mercado, sem reconhecer ao Conselho autonomia de decisão sobre o uso dos recursos privados do fundo. Por outro lado, a própria FEBRABAN, representante dos bancos com quotas no FDS, concordou com a proposta e com as modificações posteriores, provavelmente por ter avaliado o benefício de "entregar os anéis" (os pequenos recursos do FDS) "para não perder os dedos" (os vultosos recursos do FGTS).

A CEF demonstrou muita resistência em aceitar as diretrizes trazidas pelos representantes do ministério (então, porta-voz do movimento) que pautavam menor vínculo aos critérios bancários na definição do desenho da operação do financiamento. Ela, por sua vez, defendia um desenho que proporcionasse maior segurança ao Agente Operador dos recursos privados do FDS (a própria $\mathrm{CEF}^{34}$ ) já que o programa seria destinado a um

\footnotetext{
${ }^{33}$ Entrevista realizada com Cesar Ramos, em 13 de fevereiro de 2008.

${ }^{34}$ Segundo o art. 15o do Decreto 1.081 de 08 de março de 1994, que regulamentou o funcionamento do FDS, em caso de inadimplência dos mutuários, a responsabilidade de risco de crédito fica por conta do Agente Operador dos recursos do Fundo.
} 
segmento da população, prioritariamente com renda mensal até três salários mínimos, que "não oferece garantias" e "apresenta alto risco de retorno". O resultado dessa preocupação foi um desenho operacional do PCS baseado na lógica de um financiamento de crédito tradicional ${ }^{35}$, o que resultou no principal problema do programa: um desenho não ajustado às condições do tomador do financiamento.

A utilização dos recursos não-onerosos do próprio FDS para o pagamento dos custos da operação dos empréstimos e a definição da não cobrança de juros das parcelas de amortização foram os fatores que tornaram mais barato o financiamento, e permitiram ampliar o acesso ao crédito às famílias com renda inferior a três salários mínimos. A CEF também se beneficiou deste arranjo ao garantir de pronto o pagamento dos custos da operação independente dos resultados do programa ${ }^{36}$. Sem dúvida esse foi um importante mérito do Programa, no contexto em que se iniciava dentro do governo e da CEF a formulação de linhas de ações habitacionais pautadas por uma política de subsídio até então inexistente ${ }^{37}$.

Por se tratar de um crédito que exige retorno financeiro a Caixa Econômica Federal ${ }^{38}$, por responder às garantias de mercado reguladas pelo Acordo de Basiléia ${ }^{39}$, foi a única instituição financeira interessada em operar os recursos e a ser aprovada para exercer o papel do Agente Financeiro do Programa. Os demais interessados como as COHABs e

\footnotetext{
${ }^{35}$ Nos quais os contratantes costumam ser os municípios ou as construtoras que apresentam minimamente uma capacidade de investimento inicial.

${ }^{36}$ Aos custos da operação contabilizam-se as taxas de administração do FDS (taxa de risco de crédito do Agente Operador), taxa de administração do PCS do Agente Financeiro, taxa de equilíbrio do Agente Financeiro, e depósito de garantia de risco de crédito. (Informações extraídas de CEF Relatório de Gestão da CEF - prestação de contas FDS - 2005. Brasília, 2005, e Resolução no93 do CCFDS de 2004).

${ }^{37}$ É interessante notar a evolução das propostas das políticas públicas e apropriação de determinadas idéias pelo Estado. Na dissertação de RONCONI (1995) um dos itens defendidos pelo autor, e que demandou argumentação, dizia respeito ao uso dos subsídios diretos no FUNACOM. 20 anos depois, a política de subsídios é fato dado para realizar o atendimento de famílias de baixa renda dentro das diretrizes da Política Nacional de Habitação. Para se ter um exemplo, em 14 de dezembro de 2004, foi emitido pelo CCFGTS a Resolução no460 que passa a definir, entre outros aspectos, os descontos inversamente proporcionais à faixa de renda aos financiamentos habitacionais concedidos pelas Cartas de Crédito Individuais, viabilizadas a partir de operações coletivas.

${ }^{38}$ Banco comercial.

${ }^{39}$ O Acordo de Basiléia diz respeito a um acordo internacional assinado por cerca de 100 países, no final da década de 80 e revisto em 2004. Esses países concordaram com determinadas exigências a ser cumpridas pelos bancos comerciais visando assegurar as garantias de risco de crédito.
} 
instituições financeiras como a COBANSA, o Família Paulista e a Economiza não tiveram a análise de risco aprovada pelo Agente Operador ${ }^{40}$.

A Resolução no 93 do CCFDS de abril de 2004 e a Instrução Normativa no 11 de maio de 2004 do Ministério das Cidades, oficializaram o Crédito Solidário - único novo programa criado no Governo Lula - e regulamentaram a primeira seleção de propostas de financiamento referente ao exercício orçamentário daquele ano: $\mathrm{R} \$ \mathbf{2 8 6}$ milhões destinados a operação do programa, sendo que $\mathrm{R} \$ 200$ milhões seriam destinados a construção dos empreendimentos e R\$ 86 milhões de subsídios e fundo de aval ${ }^{41}$.

\subsubsection{A operação do Programa Crédito Solidário}

O organograma abaixo ilustra as relações entre os agentes envolvidos no processo de financiamento do Crédito Solidário.

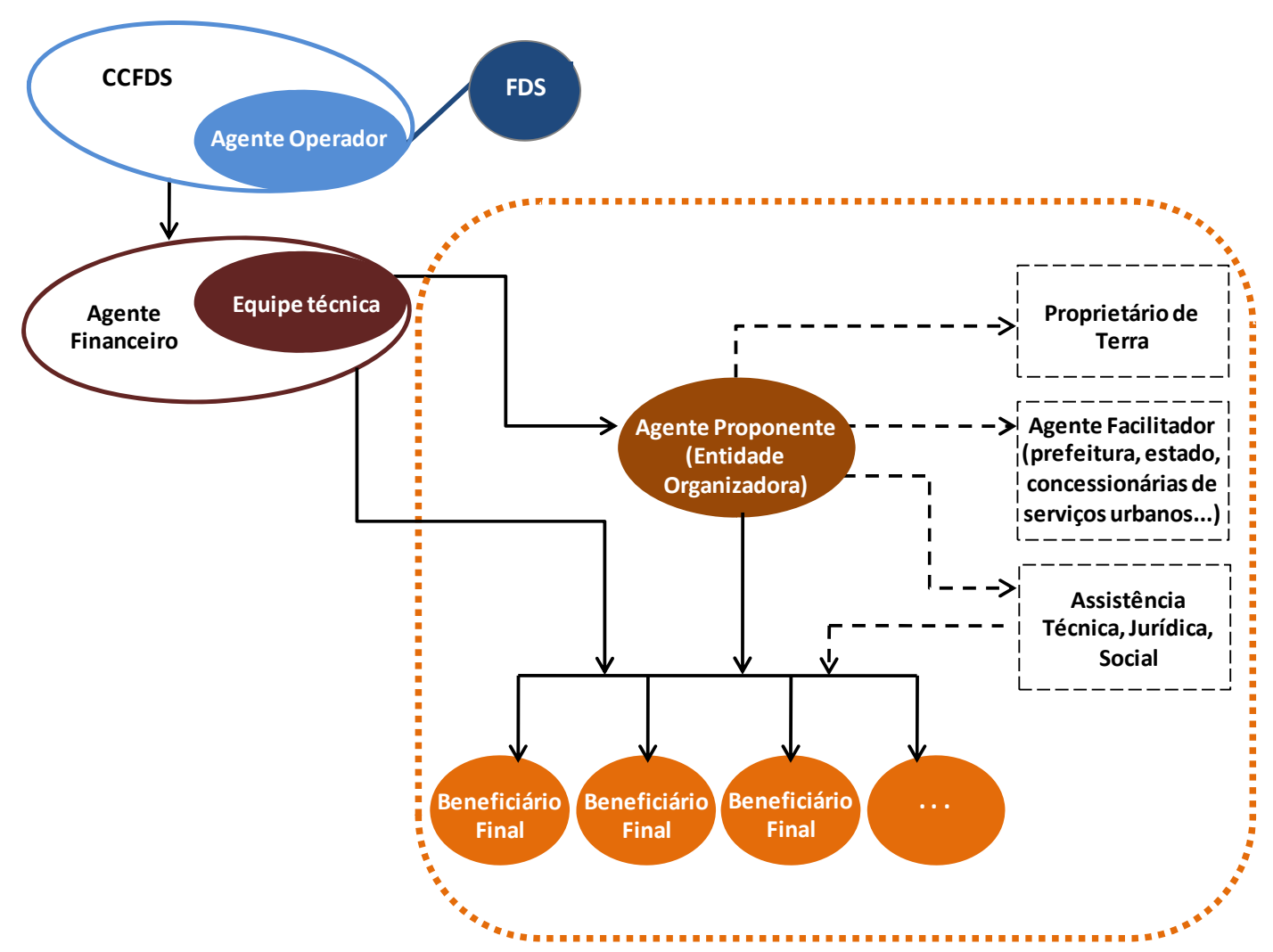

Organograma da operação do Programa Crédito Solidário.

\footnotetext{
${ }^{40}$ Essas instituições financeiras conseguem acessar os recursos do PSH (Programa de Subsídio a Habitação) e operar junto aos beneficiários finais por se tratar de recursos não-onerosos, ficando sujeitas apenas aos riscos de execução de obra. Os demais bancos de segunda linha não têm interesses de operar tais recursos, já que não garantem boas taxas de lucros.

${ }^{41}$ Conforme Resolução no94 do CCFDS de junho de 2004.
} 
A CEF, como agente operador é parte integrante do CCFDS e tem a responsabilidade de financiar os recursos do fundo ao agente financeiro, um banco comercial. Este (no caso o banco Caixa Econômica Federal) é responsável pela concessão do crédito, por meio de contratos individuais aos beneficiários finais componentes da demanda organizada pela Associação Comunitária ou Cooperativa, que desempenha o papel de entidade organizadora do empreendimento habitacional. Respondendo às regras do Programa a entidade organizadora ao firmar contrato com o agente financeiro, além de organizar e representar as famílias recebe a atribuição de formular e desenvolver toda a proposta do empreendimento.

Ela deve compor o grupo de beneficiários finais e proporcionar todo o apoio para que as famílias providenciem a documentação necessária a ser apresentada ao agente financeiro que irá submeter as famílias à análise de capacidade de comprometimento de renda e à análise cadastral, pois não podem apresentar qualquer irregularidade junto ao SERASA e SPC, e na documentação civil.

A associação caso não possua terreno próprio para pleitear os recursos do PCS, antes mesmo de contratar o financiamento, deve procurar terreno viável, inserido na malha urbana e firmar compromisso de compra e venda com o atual proprietário ${ }^{42}$, e ainda, providenciar toda a documentação fundiária da terra. Deve também elaborar projetos, orçamentos, propor cronograma de execução de obra e aprovar o empreendimento habitacional junto à prefeitura e demais órgãos licenciadores. Após cumprir essa etapa, todos os documentos são analisados e devem ser aprovados pela equipe técnica do agente financeiro (Gerências de Desenvolvimento Urbano - GIDURs) que devem emitir o aval para efetivar a contratação dos recursos do FDS.

Para que todas essas etapas sejam cumpridas, as associações e cooperativas podem ser assessoradas por uma equipe de profissionais que desempenhem assistência técnica, jurídica e social necessárias para o positivo desenvolvimento do processo.

A associação deve indicar uma entre quatro modalidades operacionais disponibilizadas pelo programa: (1) aquisição de material de construção, (2) aquisição de terreno e construção, (3) construção em terreno próprio e (4) conclusão, ampliação ou reforma de unidade habitacional. E ainda, o regime de construção a ser definido pelos

\footnotetext{
${ }^{42}$ Nos casos onde o terreno é da associação, é necessário apenas apresentar a documentação regularizada.
} 
próprios beneficiários entre as possibilidades de autoconstrução, mutirão ou pela administração direta com contratação de profissionais ou empresas para a execução de serviços especializados.

Nessa primeira sistemática o valor do investimento poderia ser composto pelos custos referentes ao terreno (aquisição e despesas de regularização), projeto (limitado a $1,5 \%$ do valor da obras e serviços propostos), construção (custos com obra e profissionais para execução da obra), materiais de construção (aquisição de material, mão de obra especializada e assistência técnica), despesas de legalização (referentes à regularização e à taxas de contratação de crédito) e seguros (de crédito; morte e invalidez permanente; danos físicos sobre o imóvel).

Do total do valor de investimento, no máximo $95 \%$ poderia ser financiados pelos recursos do FDS e o restante (mínimo 5\%) deveria ser integralizado como contrapartida financeira dos próprios beneficiários, ou como mão de obra mutirante a ser computada no orçamento como item de investimento, ou ainda, oriundos de parcerias com agentes facilitadores como prefeituras, governos do estado, ou até mesmo concessionárias de serviços urbanos.

A cada grupo associativo ficou limitado ao número máximo de 200 participantes por

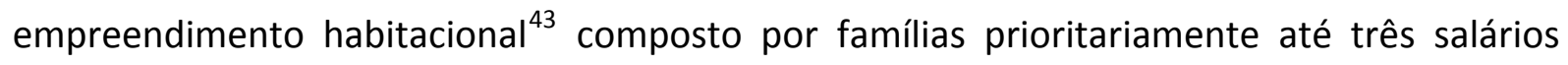
mínimos $^{44}$. E os valores máximos por financiamento foram classificados em função da modalidade operacional e das características dos municípios, como mostra a Tabela 07:

Tabela 07

Valores máximos financiados pelo PCS, conforme modalidade e perfil do município (2004)

\begin{tabular}{|c|c|c|c|c|}
\hline Seleção & $\begin{array}{l}\text { Modalidades } \\
\text { Operacionais }\end{array}$ & $\begin{array}{l}\text { Municípios com até } 50 \text { mil } \\
\text { habitantes em áreas rurais }\end{array}$ & $\begin{array}{c}\text { Municípios com } \\
\text { população superior a } 50 \\
\text { mil habitantes }\end{array}$ & $\begin{array}{c}\text { Municípios integrantes de } \\
\text { RMs }\end{array}$ \\
\hline \multirow{2}{*}{$\begin{array}{l}\text { Primeira sistemática } \\
\text { (Instrução Normativa no } \\
\text { 11, de maio de 2004) }\end{array}$} & $\begin{array}{c}\text { Conclusão, Ampliação e } \\
\text { Reforma }\end{array}$ & $\mathrm{R} \$ 5.000,00$ & $\mathrm{R} \$ 5.000,00$ & $\mathrm{R} \$ 10.000,00$ \\
\hline & Demais Modalidades & $R \$ T 7.500,00$ & $\mathrm{R} \$ 10.000,00$ & $\mathrm{R} \$ 20.000,00$ \\
\hline
\end{tabular}

fonte: www.cidades.gov.br, acesso em dezembro de 2006.

\footnotetext{
${ }^{43}$ Associações em municípios que não tem população superior a 50 mil habitantes, que não são capitais estaduais e não pertencem a regiões metropolitanas, têm que respeitar o limite máximo de 100 participantes.

${ }^{44} \mathrm{Na}$ primeira sistemática de 2004 nas regiões metropolitanas e capitais estaduais até $20 \%$ da demanda poderia ter renda entre três e cinco salários mínimos e, nos demais municípios e em áreas rurais, essa demanda poderia ser somente $10 \%$ da composição do grupo.
} 
O prazo de carência do financiamento ficou estipulado em função do tempo de execução das obras, acrescidos de mais um mês e limitando-se em 12 meses contados da data de assinatura dos contratos e liberação dos recursos. O Prazo máximo de amortização poderia alcançar 240 meses, e o valor das parcelas poderiam comprometer o limite de $25 \%$ da renda familiar, conforme a capacidade de pagamento do mutuário calculada pelo agente financeiro com base no custo da unidade habitacional e no valor do seguro. As parcelas de amortização seriam corrigidas com base somente na $\mathrm{TR}^{45}$, não incorrendo sobre elas qualquer taxa de juros. As garantias do financiamento poderiam ser feitas por Alienação Fiduciária $^{46}$ do imóvel objeto da operação após registro de incorporação, por meio de Hipoteca ou ainda por Seguro de Crédito ${ }^{47}$. Somente a alienação fiduciária foi utilizada, o que obrigava a prévia individualização da unidade habitacional, seja por meio do parcelamento como por meio da incorporação imobiliária.

Nesta primeira seleção, as associações e cooperativas enviaram ao Ministério das Cidades (Agente Gestor do Programa) suas propostas descritas em um formulário de consulta prévia. A Secretaria Nacional de Habitação analisou cada uma delas, verificando seu enquadramento nos critérios do programa e estabeleceu uma hierarquização conforme critérios divulgados na Instrução Normativa. Em seguida, retornou a cada uma das associações classificadas um "Termo de Seleção" informando que deveriam apresentar às agências da CEF todas as documentações necessárias para análise técnica, jurídica e do cadastro social das famílias participantes, obedecendo às diretrizes do Programa e os prazos legais definidos pelo Ministério.

\footnotetext{
${ }^{45}$ A TR (Taxa Referencial de Juros) foi criada no governo Collor com propósito de ser uma taxa básica de referencial para calcular juros mensais. Atualmente é utilizada para atualizar uma séria de investimentos (como cardenetas de poupança) e ainda para atualizar juros de empréstimos de programas habitacionais do Sistema Financeiro de Habitação.

${ }^{46}$ A ALIENAÇÃO FIDUCIÁRIA foi instituída como garantia de crédito a bens imóveis a partir da criação do Sistema Financeiro Imobiliário pela Lei Federal no 9514 de 1997. Atualmente tornou-se a principal opção de garantia de crédito, antes ocupado pela hipoteca, e tem sido utilizada pela CEF nos financiamentos de crédito concedido pelos programas habitacionais. No caso da alienação fiduciária, o devedor no ato da assinatura do contrato, transfere a propriedade para o credor como garantia da dívida, e mantém a posse do bem, caso o mutuário não cumpra com a obrigação do pagamento da amortização do financiamento, estará sujeito a perder o direito de propriedade sobre o imóvel.

${ }^{47}$ Segundo Cláudia Gomes, logo no início se desistiu da opção do Seguro de Crédito, pois o valor pago à seguradora era quase igual a parcela. Isso só foi possível perceber quando não se aplicou juros às parcelas, diferentemente dos outros programas em que as taxas de juros camuflavam essa informação.
} 
Em 06 de agosto de 2004 foi publicado no Diário Oficial da União o resultado dessa primeira chamada de projetos do Programa Crédito Solidário, "dos 2.759 inscritos, foram selecionados previamente 684 propostas para beneficiar 41 mil famílias em todo país" (FNRU, 2005).

O recebimento do "Termo de Seleção" criou enorme euforia às associações, que a partir daí passaram a enfrentar inúmeras dificuldades para contratar suas propostas. As razões que levaram a essas dificuldades podem ser identificadas em diversos aspectos, iniciado pelo fato dos projetos entregues ao Ministério das Cidades ${ }^{48}$ apresentarem informações ainda muito preliminares. Assim, a emissão do "Termo de Seleção" foi baseada em análises superficiais das propostas, o que acarretou na criação de expectativa de atendimento de alguns projetos, que de fato, eram inviáveis.

Segundo relatos de técnicos da GIDUR, o programa chegou muito quadrado nas agências da CEF que enfrentaram dificuldades para iniciar sua operação ${ }^{49}$. Em determinados casos, apesar da iniciativa conjunta entre Ministério das Cidades e CEF em promover seminários regionais de capacitação do PCS tanto para técnicos da CEF como para as entidades organizadoras, o impacto desses processos foram muito pouco significativos. Segundo Rocha (2007) os técnicos da CEF, que tinham o papel de orientar às entidades organizadoras e acompanhar os projetos, foram solicitados pelas associações comunitárias com os Termos de Seleção em mãos antes mesmo de estarem informados sobre o programa ou serem devidamente capacitados para tal.

A falta de capacitação contribuiu para a morosidade do processo, pois a cada novo contato estabelecido entre a entidade organizadora e CEF eram passadas novas informações e solicitações que deveriam ser respondidas para andamento da análise da proposta. A falta de estrutura institucional e limitações técnicas das próprias agências da CEF, os obstáculos operacionais, o excesso de exigências normativas e falta de flexibilidade dessas exigências dificultaram ainda mais o andamento da análise dos projetos.

Segundo liderança do MNLM de Tocantins,

\footnotetext{
${ }^{48}$ Vale apontar a informação que dentro da estrutura institucional do Ministério das Cidades existem apenas dois técnicos responsáveis pela Gestão do Programa Crédito Solidário.

${ }^{49}$ Entrevista realizada com Luciana Royer em 25 de janeiro de 2008.
} 
“... nós entramos com a consulta em 2004, só que contratamos em abril de 2006, fazendo todos os ajustes. Foi um longo caminho, por inexperiência da CEF, por ser um programa novo. E por inexperiência nossa, e conseguimos...". (Bismarque Miranda, 01.04.2008)

O desenho do programa que atribuiu às associações uma capacidade de investimento inicial muito além do que parte delas poderia oferecer, foi formatado com base nos contratos de crédito imobiliário realizados tradicionalmente pela CEF junto às prefeituras e construtoras. Essa despesa inicial significativa teve que ser aportada pela associação ou como contrapartida pelas próprias famílias, sem que tivessem a garantia da efetivação do contrato. Condição que resultou na desistência de associações que não tiveram meios para dar continuidade ao desenvolvimento da proposta por falta de condições financeiras, técnicas e institucionais para cumprir com as exigências dessa primeira etapa.

A situação apresentada pelo Fórum Nacional de Reforma Urbana demonstrava o tamanho dos empecilhos existentes para a implementação do Programa:

“... após mais de um ano de divulgação dos grupos selecionados para o Programa... apenas 182 grupos encaminharam propostas para a CEF; e até outubro de 2005, apenas 01 grupo havia conseguido acessar o crédito!" (FNRU, 2005).

Na carta entregue em 01 de outubro de 2005 ao então secretário nacional de habitação, Jorge Hereda, as principais críticas apontadas pelo FNRU, iam além dos aspectos acima levantados, e iniciavam pelo não reconhecimento do positivo desempenho das experiências anteriores de mutirões autogeridos que formataram seus programas dando relevância ao grupo organizado. A essência da crítica estava no fato do programa ter sido elaborado com base em critérios bancários e tradicionais, inadequados aos programas de interesse social, que têm como foco de atendimento um público especial que deve ser subsidiado.

Com base nas críticas apontadas acima e nas dificuldades encontradas pelos grupos em viabilizar os empreendimentos o FNRU apresentou uma lista de propostas, que colocava em questão justamente essa concepção, e iniciava com a solicitação do reconhecimento das associações e cooperativas como entidades jurídicas aptas a serem titulares dos financiamentos. O FNRU afirmava que a idéia original da proposição do programa pelo movimento popular tomava como referência a organização coletiva, e propôs ainda que o 
terreno coletivo pudesse servir como garantia real do financiamento. Por outro lado a CEF argumentava que a definição do contrato individualizado com cada um dos beneficiários significava a garantia em situações de inadimplência, pois teriam como acionar a família junto aos órgãos de controle de crédito, objetivando o controle do risco da operação.

Considerando o quadro fundiário brasileiro de gigantesca irregularidade urbana e o lento processo para realizar a regularização fundiária, o FNRU propôs que os terrenos públicos e imóveis irregulares fossem reconhecidos como garantia ao financiamento, caso contrário a obrigatoriedade de viabilizar a regularização fundiária previamente a assinatura dos contratos poderia inviabilizar diversos empreendimentos, como de fato ocorreu.

A defesa dessa proposta pelo FNRU estava apoiada na idéia que a regularização fundiária é um direito básico para a garantia da moradia digna, assim propuseram que os terrenos irregulares e aptos para receber empreendimentos habitacionais fossem inseridos no Programa Papel Passado da SNPU. E, que nos casos de terrenos públicos ainda não titulados, fossem aceitos a Concessão Especial para Fins de Moradia (CUEM) ou Concessão de Direito Real de Uso (CDRU) mediante participação do órgão público afeto a área objeto do financiamento. Mais uma vez a CEF não aceitou a proposta, defendendo que a falta de registro impedia a execução das garantias.

O FNRU apontou ainda a necessidade de ampliação dos limites de financiamento sem prejuízo às condições do programa, já que os limites individuais permitidos por ele estavam inviabilizando empreendimentos em determinadas cidades, especialmente grandes centros urbanos como São Paulo e Rio de Janeiro, onde o custo da terra é elevado.

Demandou-se também a eliminação de determinados custos que oneram o empreendimento ou condicionam um alto investimento prévio feito pela associação, como a cobrança de taxas de análise cadastral, engenharia e jurídica, e de abertura de crédito, não condizentes ao programa social operado pela CEF que é um banco público, a princípio, de finalidade social.

Foi solicitado ainda que o limite máximo de prazo de carência fosse estendido para 24 meses, pois em situações em que as obras não estivessem concluídas em 12 meses as famílias ficariam sobrecarregadas ao ter que desembolsar além do aluguel, o pagamento dos seguros e da correção monetária. 
A obrigatoriedade da cobrança dos seguros ${ }^{50}$ especialmente daquelas famílias cujos titulares tinham mais de 45 anos, onerou muito o valor da amortização e por vezes tornou a parcela incompatível com capacidade de endividamento da família, levando a sua exclusão do processo. O mesmo aconteceu em decorrência da obrigatoriedade da análise cadastral e da capacidade de endividamento das famílias que impediram a habilitação de parte expressiva dos grupos originais. Além da questão da renda e irregularidade junto aos órgãos de controle de crédito, a grande informalidade da documentação civil, presente nos segmentos mais pobres da população, foi constatado como outro impeditivo para a contratação.

O FNRU destacou a importância da CEF não desabilitar as famílias que apresentassem restrições, justificado que a inadimplência de financiamentos se dá muitas vezes pela insuficiência de renda e não por intenção deliberada, propondo que fossem analisadas as características da inadimplência buscando evitar injustiças, e propôs para determinados casos de restrição que a própria entidade viesse a ser avalista da família.

Segundo liderança da CMP de Minas Gerais, "Nós temos uma família que foi excluída porque ela estava devendo $R \$ 42,00$ na Telemar..." (Antônia de Pádua, 27.02.2008).

E por fim, o FNRU ressaltou a necessidade de fomento à capacitação e apoio por parte do Ministério das Cidades aos grupos de beneficiários, permitindo que as associações pudessem assumir plenamente suas responsabilidades na implementação do programa. A proposta poderia se concretizar com a criação de comitês de apoio ao programa Crédito Solidário em cada município, cabendo ao Ministério das Cidades também promover uma articulação entre as prefeituras, governos estaduais e concessionárias de serviços públicos urbanos na efetivação do programa.

A partir de então, o movimento popular passa a pressionar o Ministério das Cidades e a CEF para que fossem feitas as devidas mudanças apontadas.

“... desde que publicou (a resolução que criou o PCS) a gente foi fazendo adaptações... O valor não dava, o fundo garantidor não dava, tudo que eles (o movimento popular) foram colocando a gente foi mudando. Da primeira resolução $e$

\footnotetext{
${ }^{50}$ Seguro de Morte e Invalidez Permanente e Seguro a Danos Físicos sobre o Imóvel.
} 
o que se faz hoje, você pega no mínimo umas 20 alterações." (Cláudia Gomes, 24.03.2008).

Mas, de fato, essas alterações não responderam às principais críticas apontadas pelo FNRU. Segundo relatório de gestão de prestação de contas sobre as operações do FDS elaborado pela CEF em 2005, o baixo desempenho do programa teria como causa a

“... dificuldade de acesso das cooperativas e entidades associativas à assistência técnica exigida para elaboração de projetos dos empreendimentos, obtenção de licenciamento e da contratação pelo Agente Financeiro" (CEF, 2005: 12).

O que não deixa de ser verdade, apenas em termos, pois além dessa, todas as demais dificuldades apontadas anteriormente, decorreram essencialmente do próprio desenho de operação do programa proposto pela CEF ancorado na garantia de segurança de crédito da operação $^{51}$, e na sua baixa flexibilidade em modificar tais critérios.

Ponto de vista reafirmado por Ramos ao ponderar sobre a baixa repercussão do Programa Crédito Solidário,

“... a dificuldade torna oriunda da atuação da CEF, que para reverter sua cultura empresarial é difícil. A mentalidade é sempre naquele que se vai gerar lucro para a instituição (...) (fato) que gera dificuldades muito concretas, muito reais para operacionalização disso." (César Ramos, 13.02.2008).

As alterações propostas pelas resoluções do CCFDS e nas Instruções Normativas do Ministério das Cidades, e mesmo em propostas institucionais como a criação dos "Espaços Solidários" ${ }^{52}$ nas agências da CEF com o objetivo de fomentar o diálogo com as entidades organizadoras para esclarecimentos e apoio técnicos, segundo Rocha (2007), foram muito pouco significativas na solução dos obstáculos existentes. Essa afirmação que pode ser

\footnotetext{
${ }^{51} \mathrm{O}$ Risco de Crédito é de responsabilidade do agente operador (CEF- primeira linha) quanto ao retorno dos financiamentos concedidos, conforme Art.15 do Decreto no 1.081 de março de 1994 que regulamentou o FDS. Conforme Art.16, do mesmo decreto, cabe ao CCFDS definir a taxa de administração a título de remuneração do agente operador. E ainda, segundo o Art.18, o FDS está sujeito às normas do CMN e do Banco Central do Brasil.

${ }^{52}$ A Resolução Recomendada no 11 de junho de 2006 do Conselho das Cidades, com base na experiência da GIDUR/DF propôs a criação de "espaços solidários": escritórios que auxiliem as entidades proponentes, em todas as Superintendências regionais da CEF, considerando "a dificuldade pelas entidades proponentes de acesso a informação qualificada para domínio do processo de elaboração de projetos habitacionais, necessidade de apoiar e fomentar as contratações dos programas de interesse social, principalmente em relação às operações estruturadas do FGTS e do Programa Crédito Solidário".
} 
ilustrada pelos números referentes às contratações, apresentados no Quadro 02 apresentado a diante, e até mesmo pelo apelido "crédito solitário" atribuído ao programa.

A principal delas foi a criação do Fundo Garantidor, ainda em fevereiro de 2005, com - propósito de "viabilizar uma alternativa de garantia para implementação do financiamento às famílias de baixa renda que necessitam de condições especiais $e$ subsidiadas..." (Resolução no100 do CCFDS, fevereiro de 2005).

O Fundo Garantidor de cada empreendimento seria constituído a partir do acrescimento do percentual de $19,85 \%$ sobre o valor do financiamento. Os recursos do fundo garantidor poderiam ser utilizados em situações de atrasos superiores a 60 dias do encargo mensal de qualquer beneficiário, liquidação antecipada quando o saldo do fundo for maior do que a dívida, e ao término do prazo máximo de amortização dos contratos do grupo.

A proposta deste Fundo Garantidor criou uma alternativa de garantia de crédito, entretanto onerou significativamente a parcela de cada contrato em relação ao valor inicial, e conseqüentemente elevou a capacidade de pagamento a ser comprovada pelo beneficiário. Vale ressaltar que dos 203 empreendimentos contratados até dezembro de 2007, 113 foram assinados com Fundo Garantidor, mostrando que essa opção, apesar de elevar os valores das parcelas, foi considerada uma alternativa aceita pelos grupos.

Em dezembro de 2005 ocorreu a alterou de valores máximos dos financiamentos ${ }^{53}$ indicados pela Tabela 08, abaixo.

Tabela 08

Valores máximos financiados pelo PCS, conforme modalidade e perfil do município (2005/2006)

\begin{tabular}{|c|c|c|c|c|c|}
\hline Seleção & $\begin{array}{l}\text { Modalidades } \\
\text { Operacionais }\end{array}$ & $\begin{array}{l}\text { Municípios com até } 50 \\
\text { mil habitantes em } \\
\text { áreas rurais }\end{array}$ & $\begin{array}{l}\text { Municípios com } \\
\text { população superior a } \\
50 \text { mil habitantes }\end{array}$ & $\begin{array}{c}\text { Municípios integrantes } \\
\text { de RMs }\end{array}$ & $\begin{array}{c}\text { Municípios } \\
\text { integrantes das RMs } \\
\text { do Rio de Janeiro e } \\
\text { São Paulo }\end{array}$ \\
\hline \multirow{2}{*}{$\begin{array}{c}\text { Segunda Sistemática } \\
\text { (Instrução Normativa } \\
\text { no 39, de dezembro } \\
\text { de 2005) }\end{array}$} & $\begin{array}{l}\text { Conclusão, } \\
\text { Ampliação e } \\
\text { Reforma }\end{array}$ & $\mathrm{R} \$ 7.500,00$ & $\mathrm{R} \$ 10.000,00$ & $\mathrm{R} \$ 10.000,00$ & $\mathrm{R} \$ 10.000,00$ \\
\hline & $\begin{array}{l}\text { Demais } \\
\text { Modalidades }\end{array}$ & $\mathrm{R} \$ 10.000,00$ & $\mathrm{R} \$ 10.000,00$ & $\mathrm{R} \$ 20.000,00$ & $R \$ 25.000,00$ \\
\hline
\end{tabular}

fonte: www.cidades.gov.br, acesso em dezembro de 2006.

\footnotetext{
53 Instrução Normativa no38 de dezembro de 2005.
} 
Mesmo com essas reformulações, foram contratados apenas 24 projetos no valor total de R\$2 20.717.286,93 para atendimento habitacional de 1.640 famílias $^{54}$, um pouco mais de $10 \%$ da meta aprovada pelo CCFDS de $\mathrm{R} \$ 250$ milhões. Esses empreendimentos aprovados foram destinados em média a famílias com renda mensal entre 1 e 2 salários mínimos, em 19 municípios distribuídos entre os estados de Goiás, Santa Catarina, Rio Grande do Sul e Paraná, Piauí, Maranhão e Sergipe.

A partir de 2006 passa a vigorar a nova sistemática ${ }^{55}$, que modificou alguns detalhes do programa como o envio da pré-viabilidade que passa a entrar pelos Escritórios de Negócios das Agências da CEF e não mais pelo Ministério das Cidades. Tal fato reforçou o peso político à CEF em relação ao Programa. Peso político o qual a CEF vem ganhando desde que passou a ser exclusiva operadora dos recursos públicos federais destinados à política habitacional,

“... na prática, a enorme capilaridade e poder da Caixa, presente em todos os municípios do país, acaba fazendo que a decisão sobre a aprovação dos pedidos de financiamentos e acompanhamento dos empreendimentos seja sua responsabilidade" (BONDUKI, 2008:97).

O conflito de posições muitas vezes estabelecido entre Ministério das Cidades e CEF, é justificado pelo fato da CEF estar subordinada ao Ministério da Fazenda que, via de regra, aponta impedimentos às políticas com orientações de caráter social, e que reflete uma contradição interna ao governo que mantém as diretrizes macro-econômica semelhantes ao governo anterior, e implanta políticas de caráter social, respondendo aos interesses dos setores populares.

Outro aspecto alterado foi a livre porcentagem do valor do financiamento a ser destinado ao desenvolvimento do projeto antes limitados a $1,5 \%$ do valor de investimento. $E$ ainda a possibilidade de utilização de recursos de programa de subsídios habitacionais (como por exemplo, PSH) para complementar os valores financiados do PCS.

Ao final de dezembro de 2006 somaram-se mais 87 contratos firmados. Esses empreendimentos totalizaram 4.904 atendimentos habitacionais, destinadas a famílias com

\footnotetext{
${ }^{54}$ Disponível em www.cidades.gov.br, consultado em 15 de março de 2008.

${ }^{55}$ Instrução Normativa no39 de dezembro de 2005.
} 
renda mensal entre 1 e 3 salários mínimos ${ }^{56}$. Novamente os contratos efetivados ficaram muito abaixo das metas estabelecidas para o ano, quando dos $\mathrm{R} \$ 348,5$ milhões do FDS reservados $^{57}$ foram contratados o montante de $\mathrm{R} \$ \mathbf{8 1 . 9 0 4 . 2 8 5 , 2 8}$, representando pouco mais de $20 \%$ do total.

Em $2007^{58}$, são propostas novas alterações como a alteração das faixas de renda bruta mensal dos beneficiários finais em $\mathrm{R} \$ 1.050,00$, permitindo a composição do grupo por 35\% de famílias dos municípios pertencentes a regiões metropolitanas com renda entre $\mathrm{R} \$$ $1.050,00$ e $\mathrm{R} \$ 1.750,00$, e $25 \%$ para demais municípios e zonas rurais. Os limites máximos dos valores financiados foram novamente alterados conforme indica a tabela abaixo, e também foi redefinida a classificação de alguns municípios.

Tabela 09

Valores máximos financiados pelo PCS, conforme modalidade e perfil do município (2007)

\begin{tabular}{|c|c|c|c|c|c|}
\hline Seleção & $\begin{array}{l}\text { Modalidades } \\
\text { Operacionais }\end{array}$ & $\begin{array}{l}\text { Municípios com até } 50 \\
\text { mil habitantes em } \\
\text { áreas rurais }\end{array}$ & $\begin{array}{l}\text { Municípios com } \\
\text { população superior a } \\
50 \text { mil habitantes }\end{array}$ & $\begin{array}{c}\text { Municipios integrantes } \\
\text { de RMs }\end{array}$ & $\begin{array}{c}\text { Municípios das RMs } \\
\text { do Rio de Janeiro, } \\
\text { São Paulo, Campinas, } \\
\text { Baixada Santista e } \\
\text { Belo Horizonte e } \\
\text { RIDE-DF }\end{array}$ \\
\hline \multirow{2}{*}{$\begin{array}{c}\text { Segunda Sistemática } \\
\text { (Instrução Normativa } \\
\text { no 04, de fevereiro } \\
\text { de 2007) }\end{array}$} & $\begin{array}{l}\text { Conclusão, } \\
\text { Ampliação e } \\
\text { Reforma }\end{array}$ & $\mathrm{R} \$ 7.500,00$ & $\mathrm{R} \$ 10.000,00$ & $\mathrm{R} \$ 10.000,00$ & $\mathrm{R} \$ 10.000,00$ \\
\hline & $\begin{array}{c}\text { Demais } \\
\text { Modalidades }\end{array}$ & $R \$ 12.000,00$ & $\mathrm{R} \$ 18.000,00$ & $R \$ 24.000,00$ & $R \$ 30.000,00$ \\
\hline
\end{tabular}

fonte: www.cidades.gov.br, acesso em março de 2008.

A porta de entrada dos processos é alterada novamente, e estes passam a ser recebidos pelas GIDURs e não mais pelos Escritórios de Negócio da CEF, atribuindo maior importância ao olhar técnico. Buscando impor maior agilidade aos processos foram definidos prazos limites para análise técnica da CEF e contratação das propostas selecionadas.

Ao final desse ano, somaram-se a esses mais 92 contratações no valor total

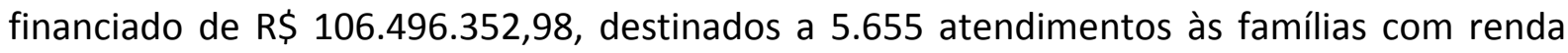

\footnotetext{
${ }^{56}$ Disponível em www.cidades.gov.br, consultado em 15 de março de 2008.

${ }^{57}$ Sendo $\mathrm{R} \$ 200$ milhões destinados ao processo construtivo, $\mathrm{R} \$ 108$ milhões aos subsídios para pagamentos das taxas e R\$ 39,7 milhões para composição do Fundo Garantidor com base na resolução no 106 de 23 de novembro de 2005.

${ }^{58}$ Instrução Normativa no 04 do Ministério das Cidades de 06 de fevereiro de 2007.
} 
mensal entorno de 3 salários mínimos ${ }^{59}$. Alcançando 31,7\% da meta estabelecida de $\mathrm{R} \$$ 335,7 milhões para aquele ano ${ }^{60}$.

A observação quantitativa mostra que os desempenhos anuais foram muito aquém das metas estabelecidas pelo CCFDS e que ao final dos três anos de operação do Programa Crédito Solidário foram totalizados o universo de 203 empreendimentos habitacionais contratados entre 2005 e 2007, a partir do investimento de $\mathrm{R} \$ 209.117 .925,19$ dos recursos do FDS, para viabilizar 12.199 atendimentos habitacionais ${ }^{61}$.

\section{Quadro 2}

Desempenho quantitavo do Programa Crédito Solidário

\begin{tabular}{|cccc|}
\hline & $\mathbf{2 0 0 5}$ & $\mathbf{2 0 0 6}$ & $\mathbf{2 0 0 7}$ \\
\hline Metas (\$ FDS) & $\mathrm{R} \$ 250$ milhões & $\mathrm{R} \$ 348,5$ milhões & $\mathrm{R} \$ 335,7$ milhões \\
\hline Recursos Contratados & $\mathrm{R} \$ 20.717 .267$ & $\mathrm{R} \$ 81.904 .295$ & $\mathrm{R} \$ 106.496 .363$ \\
\hline$\%$ \$ utilizado & $\mathbf{8 \%}$ & $\mathbf{2 4 \%}$ & $\mathbf{3 2 \%}$ \\
\hline Contratos Assinados & 24 & 87 & 92 \\
\hline $\begin{array}{c}\text { Atendimentos } \\
\text { Habitacionais }\end{array}$ & 1640 & 4904 & 5655 \\
\hline
\end{tabular}

fonte dos dados: www.cidades.gov.br.

\footnotetext{
${ }^{59}$ Disponível em www.cidades.gov.br, consultado em 15 de março de 2008.

${ }^{60}$ Resolução no114 do CCFDS de 19 de janeiro de 2007.

${ }^{61}$ Disponível em www.cidades.gov.br, consultado em 15 de março de 2008.
} 


\section{o Crédito Solidário na prática: o lugar da autogestão no Governo Lula.}

"O que acontece com os modelos habitacionais no Brasil? Você pega uma estrada e vai andando. Aí você vê 30 casinhas ali, bem longe da cidade. Normalmente elas são feitas bem longe da cidade. Ou seja, ao invés de resolver o problema habitacional, parece que resolve o problema de algumas pessoas que não gostam que pobres estejam dentro da cidade. Então os afasta bem para longe.

É preciso dar um pouco de estética, é preciso dar opção...

Você não tem o direito de dizer: mas eu não quero minha casa assim, eu gostaria que fosse assim. Você não tem o direito, ou seja, é uma coisa padronizada, em que só se pensa o custo, e não se pensa a dignidade, a auto-estima, a respeitabilidade das pessoas. Essa é uma coisa que nós vamos ter que pensar.

... Você pode não fazer tudo, mas o que você fizer tem que ser bem feito. $O$ que você fizer tem que dar o mínimo de respeitabilidade e dignidade às pessoas. "

Presidente Luiz Inácio Lula da Silva, Abertura da 1․ Conferencia Nacional das Cidades, outubro de 2003

A análise do Programa Crédito Solidário (PCS) tomou por base a caracterização quantitativa, bem como, os fragmentos de cidade empreendidos pelo Programa, as potencialidades e limites impostos a sua efetivação em relação à gestão dos recursos e da obra, e o fortalecimento da organização social. Para sua elaboração nos apoiamos nas informações e dados disponibilizados pelos agentes do processo, pelas entrevistas realizadas com representantes dos movimentos populares, assessores técnicos e gestores públicos (das prefeituras e do Ministério das Cidades) e operadores da CEF, e ainda pelo trabalho de campo realizado em três empreendimentos contratados pelos recursos do PCS nas cidades de Goiânia - GO, Salvador - BA e São Paulo - SP.

No início da pesquisa definimos como referência de análise a experiência positiva ocorrida no Município de São Paulo, pelo Programa FUNAPS-Comunitário (1989-1992). Essa perspectiva foi adotada com base em relatos de alguns entrevistados ${ }^{1}$ que apontaram como

\footnotetext{
${ }^{1}$ Especialmente as entrevistas realizadas com Leonardo Pessina e Evaniza Rodrigues.
} 
objetivo do pleito do PCS a oportunidade de difundir a experiência autogestionária ${ }^{2}$ para os demais territórios do país.

Constatamos no decorrer desse processo, após entrar em contato com outros interlocutores e com diversas experiências do Crédito Solidário espalhadas pelo Brasil, que insistir nessa referência para analisar as questões que estavam por traz da proposta do Programa seria um erro. Pois estaríamos nos restringindo a uma parcialidade existente e que não representa o universo de pontos de vista e motivações envolvidos no processo de elaboração e implementação do Programa.

Respeitadas as heterogeneidades de posições presentes em cada um dos agentes envolvidos no processo ${ }^{3}$, percebemos que essa multiplicidade de visões contribuiu para que fosse estabelecido entre movimento popular (que pleiteou), a CEF (que formulou o desenho da operação) e o Governo (que tornou público) um diálogo de surdos e mudos em torno do princípio da autogestão vinculado à proposta. Isso porque cada um deles baseado em suas referências, necessidades e limites impôs uma expectativa sobre o programa. Trata-se de uma ciranda de forças na qual o poder de pressão e de imposição de sua própria perspectiva fez com que prevalecesse uma visão sobre as demais.

Buscamos então, construir a análise partindo desta percepção e cientes de que estávamos tratando de um programa habitacional de poucos e finitos recursos, de características particulares, e integrante de uma estrutura institucional e política muito mais ampla.

Assim, ao analisar a prática resultante da implementação do Crédito Solidário buscamos inicialmente responder questões mais abrangentes, e considerando que o programa foi proposto como resposta a demanda do movimento popular, questionamos o quanto o programa respondeu à proposta original? Qual o grau de importância atribuída ao PCS e como se insere na Política Nacional de Habitação? Qual seu impacto no déficit habitacional? Considerando a diversidade nacional, à qual realidade sócio-territorial brasileira que o programa tem melhor respondido?

\footnotetext{
${ }^{2}$ Isso porque, foi por meio do FUNACOM que o movimento popular vivenciou na prática o princípio da autogestão, fato que possibilitou o amadurecimento de suas propostas em relação à questão habitacional e suas posturas perante o Estado, com base no processo descrito por PAZ (1996) e exposto nos capítulos anteriores.

${ }^{3}$ Lembrando que cada um desses agentes é composto por pessoas que apresentam visões divergentes entre si.
} 
$E$, se nos parecia que a idéia de autogestão foi apropriada por diferentes maneiras ${ }^{4}$, não caberia apresentarmos questões onde esta palavra estivesse explicitada, pois acabaríamos entrando no mesmo diálogo de surdos e mudos. Assim buscamos apontar questões que traziam determinados aspectos inerentes ao princípio da autogestão, que poderiam dar evidências do caráter do programa e indicar pistas de como (e se) esse princípio foi apropriadoo pelo desenho operacional, ou permitiu na prática proporcionar o fortalecimento da organização da sociedade, e ainda, garantir a produção oficial da cidade com qualidade urbana e ambiental.

Questionamos ainda em que medida os empreendimentos têm considerado e proporcionado "a dignidade, a auto-estima, a respeitabilidade das pessoas" ${ }^{5}$ ? Em qual território estão sendo construídos os novos conjuntos habitacionais por meio do Programa Crédito Solidário? Distantes ou próximas dos núcleos urbanos consolidados? Apresentam infra-estrutura instalada? Com quais características? Quais são os rebatimentos no ambiente (os agravos) dessas construções? O PCS tem produzido projetos habitacionais de qualidade, com um "pouco de estética" ${ }^{6}$ nos quais as famílias têm direito de optar sobre sua futura moradia? Que tipo de fragmentos de cidades o PCS tem empreendido? Qual a qualidade desses espaços produzidos? O Programa tem como fim, além da construção da moradia, proporcionar o fortalecimento dos grupos organizados envolvidos no processo? Tem como fim, ou tem apresentado como conseqüência, atribuir a esses processos de produção um diferencial de qualidade? E se de fato esses forem seus objetivos, quais os meios que têm sido utilizados para alcançá-los?

\subsection{Análise dos resultados do Programa Crédito Solidário}

Para tratar dos resultados do Programa Crédito Solidário, buscamos inicialmente contextualizar o tamanho do déficit habitacional brasileiro e sua caracterização conforme as

\footnotetext{
${ }^{4}$ Várias interpretações do entendimento da autogestão nos processos de produção habitacional foram sugeridas pelos agentes entrevistados e por conversas informais. Essas interpretações tratavam desde a idéia que se aproximava da participação em todas as etapas do processo de produção e gestão, até a simples participação no mutirão, passando pelo entendimento da gestão de recursos feito por um grupo seleto (diretoria ou comissões) de representante dos beneficiários finais.

${ }^{5}$ Termos utilizados pelo Presidente Lula, em discurso da Abertura da Primeira Conferência Nacional das Cidades, em outubro de 2003.

${ }^{6}$ Idem.
} 
especificidades regionais definidas pela Fundação João Pinheiro (BRASIL/MCID/SNH, 2008) e especificidades sócio-econômicas definidas pela tipologia de municípios utilizada pelo Plano Nacional de Habitação (BRASIL/MCID/SNH, 2008b). E, a partir desse contexto, realizar a análise dos números do PCS, parte integrante da Política Nacional de Habitação, e indicar algumas hipóteses que busquem justificá-los.

\subsubsection{Breve quadro do déficit habitacional}

A Fundação João Pinheiro mostrou que o crescimento contínuo do déficit habitacional brasileiro persiste apesar da tendência de desaceleração ${ }^{7}$ e foi estimado em 7,935 milhões de unidades habitacionais (2006). A distribuição das carências habitacionais no país com pouco mais de $80 \%$ da população urbana $^{8}$ se dá de forma desigual no território e apresenta o seu maior universo em números absolutos nas regiões mais populosas e urbanizadas $^{9}$, especialmente as regiões metropolitanas ${ }^{10}$ que concentram cerca de $31 \%$ da população brasileira e que representam $28,5 \%$ do déficit habitacional do país.

\section{Gráfico 5}

\section{Participação dos componentes no deficit habitacional URBANO (2006) - Brasil e Regiões.}

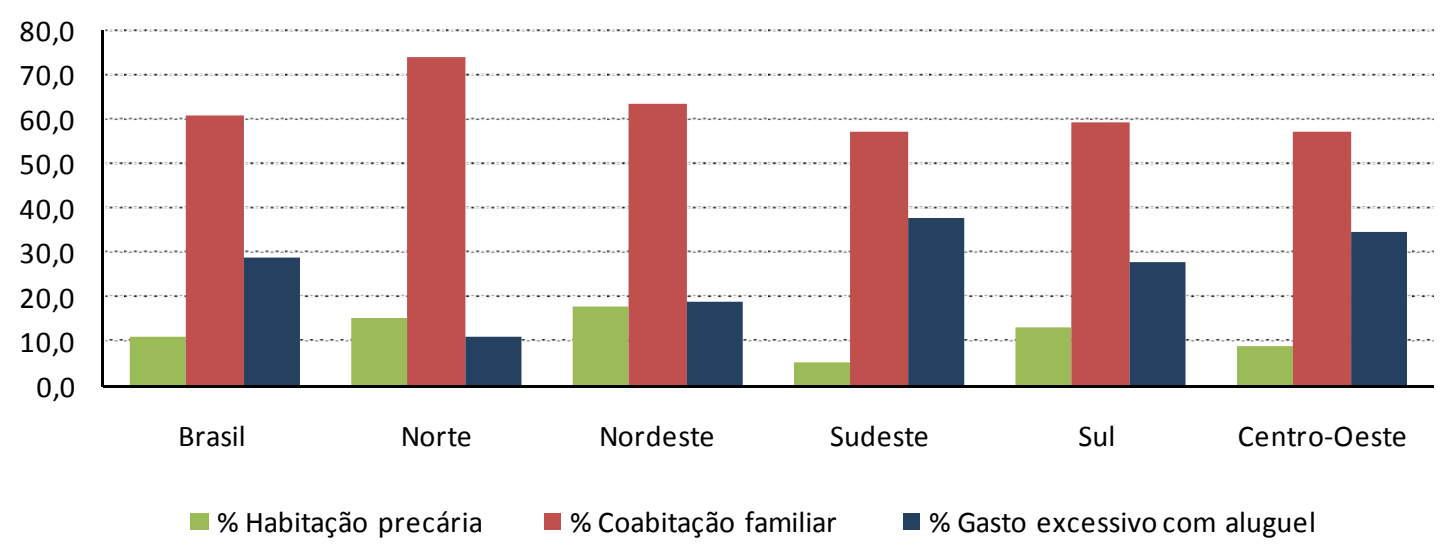

fonte: (BRASIL/MCID/SNH, 2008) .

\footnotetext{
${ }^{7}$ Os estudos de 2004, 2005 e 2006 do déficit habitacional realizado pela Fundação João Pinheiro (FJP), tomaram como base de informações a PNAD, podendo assim ser comparados entre si.

8 IBGE, Censo de 2000, estimou o total da população urbana em 138 milhões de habitantes, representando $81,3 \%$ do total, onde estão concentrados 6,543 milhões ao total do déficit habitacional. As regiões que apresentam maior número de população vivendo em áreas urbanas são SE (65,5milhões) e NE (32,9 milhões).

${ }^{9}$ As regiões Nordeste e Sudeste juntas representam mais de $70 \%$ do déficit habitacional urbano, e demandam respectivamente 1,837 e 2,794 milhões de novas moradias.

${ }^{10}$ As Regiões Metropolitanas pesquisadas pela PNAD e consideradas pela Fundação João Pinheiro foram: RIDEDF, Belém, Fortaleza, Recife, Salvador, Belo Horizonte, Rio de Janeiro, São Paulo, Curitiba e Porto Alegre.
} 
O déficit habitacional rural estimado em 1,49 milhões de novas unidades habitacionais está concentrado na região Nordeste que representa sozinha aproximadamente $60 \%$ deste total, e cujo componente principal é a precariedade habitacional. O cenário se inverte nas regiões Sul e Sudeste do país, conforme ilustrado pelo Gráfico 6, onde a coabitação familiar é o principal componente do déficit rural.

\section{Gráfico 6 \\ Participação dos componentes no deficit habitacional RURAL (2006) - Brasil e Regiões.}

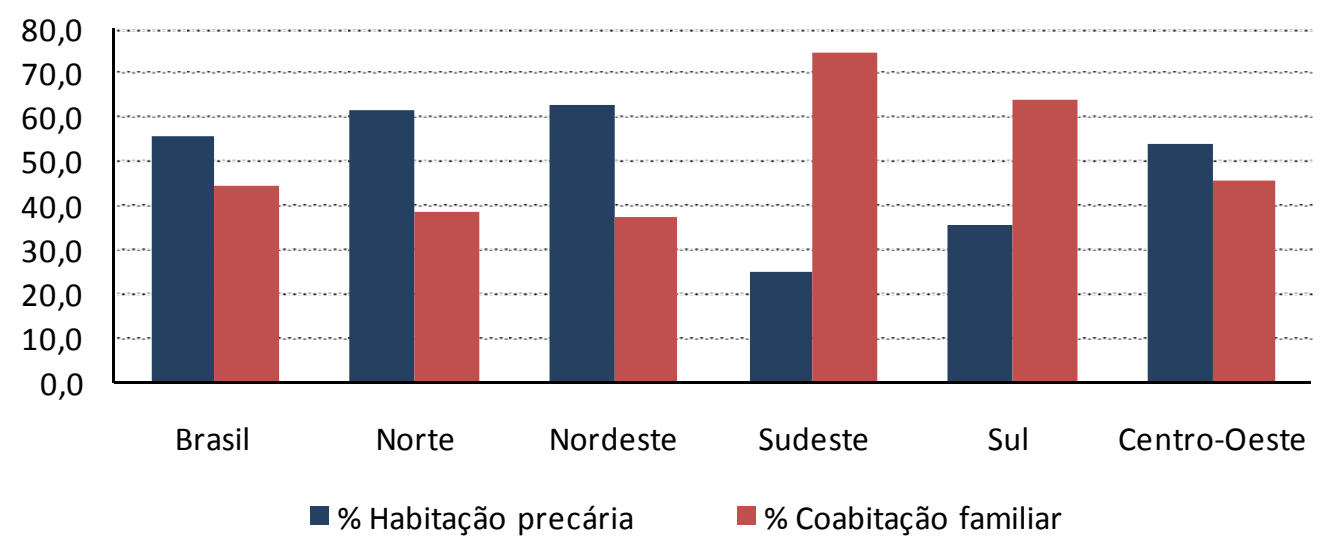

fonte: (BRASIL/MCID/SNH, 2008).

As características predominantes das necessidades habitacionais se diferenciam muito de região para região e estão relacionadas com suas dinâmicas econômicas e produtivas, que por sua vez atraem ou expulsam população ${ }^{11}$. Para realizar uma observação do desempenho do Crédito Solidário (programa de abrangência nacional) com o objetivo de compreender à qual tipo de necessidade habitacional e à qual região o Programa tem melhor respondido, adotamos além da distribuição territorial pelos 27 estados federativos, o uso das tipologias de municípios propostas pelo $\operatorname{PLANHAB}^{12}$, que proporcionou uma caracterização um pouco mais aproximada das realidades locais.

\footnotetext{
${ }^{11}$ As informações referentes às características regionais foram extraídas de BRASIL. MINISTÉRIO DAS CIDADES. SECRETARIA NACIONAL DE HABITAÇÃO. Caderno 1 - Plano Nacional de Habitação: contribuições dos Seminários regionais. Brasília: Ministério das Cidades, 2008b.

${ }^{12}$ Trata-se de uma classificação de 11 tipos de municípios resultantes de agrupamento das 19 tipologias de cidades propostas originalmente por estudo desenvolvido por Tânia Bacelar ao Ministério da Integração para subsidiar a Política Nacional de Desenvolvimento Regional, que permitiu caracterizar as cidades em função dos seus níveis de pobreza/ riqueza, desigualdades sociais, e ainda, em relação ao grau de incidência de problemas urbanos, sociais e ambientais. Mais informações podem ser obtidas pelo site: http://www.cidades.gov.br/secretarias-nacionais/secretaria-de-habitacao/planhab.
} 


\section{Quadro 3}

\section{Características Gerais das Tipologias de Municípios do PlanHab.}

\begin{tabular}{|c|c|c|c|c|c|}
\hline $\begin{array}{l}\text { População do } \\
\text { Município }\end{array}$ & $\begin{array}{l}\text { Tipologia } \\
\text { PlanHab }\end{array}$ & Características Geriais & $\begin{array}{l}\text { No de } \\
\text { Municípios }\end{array}$ & $\begin{array}{r}\text { Deficit Habita } \\
\text { Básico Total-U } \\
(2006)\end{array}$ & $\begin{array}{l}\text { onal } \\
\text { ANO }\end{array}$ \\
\hline \multirow{5}{*}{$\begin{array}{l}\text { Municípios das } \\
\text { RMs e de + de } \\
100 \text { mil habitantes }\end{array}$} & A & RMs de SP e RJ & 54 & 1.141 .323 & 14,40 \\
\hline & B & $\begin{array}{l}\text { Demais RMs e aglomerações urbanas do } \\
\text { centro/sudeste/sul }\end{array}$ & 187 & 856.930 & 10,80 \\
\hline & C & $\begin{array}{l}\text { Espaços Urbanos aglomerados e capitais mais } \\
\text { prósperas do norte e nordeste }\end{array}$ & 63 & 626.270 & 7,90 \\
\hline & D & Centros regionais prósperos do centro-sul & 215 & 816.782 & 10,30 \\
\hline & E & $\begin{array}{l}\text { Centros regionais em regiões pobres do norte } \\
\text { e nordeste }\end{array}$ & 57 & 544.606 & 6,90 \\
\hline \multirow{3}{*}{$\begin{array}{r}\text { de } 20 \text { mil a } 100 \\
\text { mil habitantes }\end{array}$} & $\mathbf{F}$ & Prósperos & 252 & 327.712 & 4,10 \\
\hline & G & Em desenvolvimento & 274 & 401.581 & 5,10 \\
\hline & H & Centros urbanos em áreas rurais pobres & 84 & 386.324 & 4,90 \\
\hline \multirow{6}{*}{$\begin{array}{l}\text { menos de } 20 \text { mil } \\
\text { habitantes }\end{array}$} & $\mathbf{I}$ & Prósperos & 976 & 288.870 & 3,60 \\
\hline & J & Em desenvolvimento & 1437 & 565.786 & 7,10 \\
\hline & K & Pobres & 1406 & 610.846 & 7,70 \\
\hline & \multicolumn{3}{|c|}{ SUBTOTAL URBANO } & 6.567 .030 & 82,80 \\
\hline & \multicolumn{3}{|c|}{ SUBTOTAL RURAL } & 1.367 .689 & 17,20 \\
\hline & \multicolumn{3}{|r|}{ TOTAL } & 7.934.719 & 100,00 \\
\hline
\end{tabular}

fonte de dados: http://www.cidades.gov.br/secretarias-nacionais/secretaria-de-habitacao/planhab. Tendências e Cenários do Plano Nacional de habitação, acesso em junho de 2008 e (BRASIL/MINISTÉRIO DAS CIDADES/ SECRETARIA NACIONAL DE HABITAÇÃO/ CONSÓRCIO PLANHAB, 2009).

O Quadro 3 sintetiza a classificação de 11 tipos de municípios, distribuídos em três grandes grupos com base no número de habitantes. Estes municípios foram organizados em função de suas características territoriais e de seu grau de desenvolvimento econômico, aspectos que refletem nas características de suas estruturas urbanas. Os tipos A a E apresentam, em linhas gerais, altos índices de déficit habitacional absoluto, altas taxas de crescimento populacional nas áreas periféricas dos aglomerados urbanos, e contribuem com cerca de $46 \%$ do déficit habitacional total no país. Os municípios médios pertencentes ao segundo grande grupo se distribuem entre o tipo F que apresenta alta taxa de urbanização, crescimento moderado e baixos índices de precariedade; o tipo G que apresenta níveis moderados de precariedade e pobreza, e relativa estagnação; e o tipo H que apresenta baixa 
taxa de urbanização e alta concentração do déficit habitacional na zona rural. E por fim, o terceiro grande grupo de pequenos municípios, com menos de 20 mil habitantes, se divide de forma similar aos municípios médios, em função de suas características econômicas, entre os tipos I (prósperos), J (consolidados) e K (pobres). Esses agrupam cerca de 3,8 mil pequenos municípios que representam $18,5 \%$ da população, quase $36 \%$ de todo o déficit habitacional total, e $70 \%$ do déficit habitacional rural do país ${ }^{13}$.

\section{Gráfico 7}

Distribuição do percentual do deficit habitacional Urbano (2006), por tipo de município do PLANHAB.

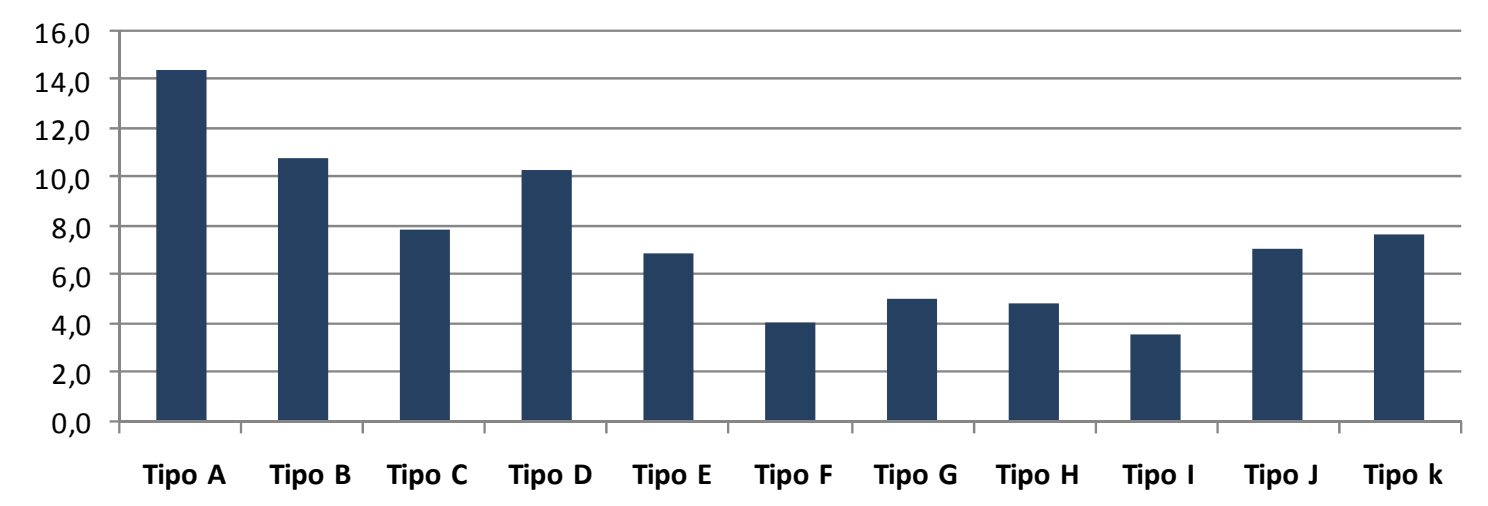

fonte: BRASIL/MINISTÉRIO DAS CIDADES/ SECRETARIA NACIONAL DE HABITAÇÃO/ CONSÓRCIO PLANHAB, 2009.

O déficit habitacional urbano (2006), conforme ilustrado pelo Gráfico 7, se distribui de forma desigual entre os 11 tipos de municípios brasileiros. Os maiores percentuais concentram-se no primeiro grande grupo dos tipos A a E, onde 579 municípios populosos e intensamente urbanizados, concentram o déficit habitacional urbano. E no outro extremo

\footnotetext{
${ }^{13}$ Os municípios Tipo A: regiões metropolitanas de São Paulo e Rio de Janeiro, Tipo B: regiões metropolitanas de Porto Alegre, Florianópolis, Curitiba, Campinas, Belo Horizonte, Distrito Federal e Vitória, Tipo C: alomerados urbanos no entorno de Fortaleza, Natal, João pessoa, Recife, Aracaju, Salvador, Palmas, Boa Vista e Porto Velho, Tipo D: aglomerados urbanos no entorno das capitais do Centro-oeste e outros aglomerados espalhados pelos estados do Sudeste e Sul, Tipo E: aglomerados urbanos e entorno das demais capitais da região norte e outros espalhados pelo nordeste e norte do país. Tipo F: centros urbanos em espaços rurais concentrados principalmente no interior do estado de São Paulo, sul do estado de Minas Gerais e de forma pulverizada pelos estados do centro-sul do país. Os municípios Tipo G: concentram-se no centro do estado de Minas Gerais, no interior dos estados do Rio de Janeiro e Espírito Santo, sul do estado de São Paulo, interior dos estados do Sul do país e pulverizados pelos demais estados. Os municípios Tipo $\mathbf{H}$ estão concentrados, em especial, no interior dos estados do nordeste, norte de Minas Gerais, e de forma pulverizada pelos estados da região Norte.
} 
estão os 2843 municípios tipos J e K que também contribuem com elevado percentual ao déficit habitacional básico, porém concentram a carência habitacional rural.

\subsubsection{Programa Crédito Solidário em números (2005-2007)}

Ao analisarmos os números referentes aos contratos assinados pelo PCS foi possível constatar que sua distribuição se deu de forma desigual entre as regiões do país concentrando mais da metade dos contratos nos estados do Sul com 107 do total de 203 empreendimentos aprovados. Os estados que mais se destacaram em número de contratações foram Rio Grande do Sul, Santa Catarina, e Goiás com cerca de 60\% do total. Enquanto os estados do Sudeste (em especial Minas Gerais e São Paulo) e do Nordeste (com exceção de Alagoas que não contratou) representaram juntos $26 \%$ do total. A região Norte realizou o menor número de contratos, representando apenas $6,4 \%$ do total, firmados nos estados de Tocantins, Pará e Rondônia. Os estados da Alagoas, Amazonas, Amapá, Acre e Roraima e ainda o Distrito Federal não realizaram contratações pelo programa.

\section{Gráfico 8}

№ de Contratos do PCS (2005-2007) distribuidos por Região

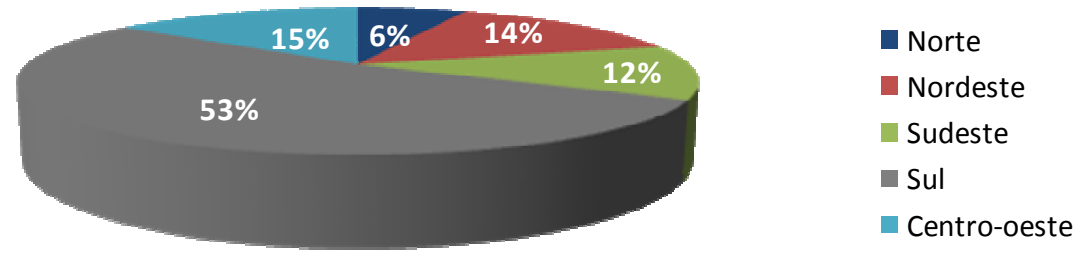

Elaboração própria

fonte de dados: www.cidades.gov.br

Ao observarmos a distribuição de contratos realizados pelos 11 tipos de municípios do PLANHAB, verificamos uma significativa preponderância dos municípios Tipo B, ou seja, em municípios pertencentes às regiões metropolitanas das capitais e aglomerados urbanos do centro-sul do país. Dos 69 empreendimentos aprovados nessa tipologia, somente sete foram destinados às capitais, sendo cinco contratos em Belo Horizonte ${ }^{14}$ e dois em Porto Alegre.

\footnotetext{
${ }^{14}$ A justificativa para a contratação desses projetos está no fato que em Belo Horizonte os movimentos já apresentavam certa organização, pois tinham vivido no passado de uma experiência de produção
} 
Os municípios pertencentes aos tipos $\mathrm{I}$ e $\mathrm{J}^{15}$ totalizaram 42 contratos, dos quais somente dois não pertenciam aos estados do sul. Na região Sul o componente cohabitação familiar é preponderante na composição do déficit habitacional rural, e deve-se destacar que a cohabitação não necessariamente representa como déficit habitacional em sua totalidade, já que parte das famílias é convivente por opção ${ }^{16}$.

Os municípios do primeiro grande grupo que reúne municípios das regiões metropolitanas e com população acima de 100 mil habitantes foram responsáveis por cerca de $64 \%$ do total de contratos assinados, enquanto os municípios pequenos ficaram responsáveis por $23,65 \%$, e os municípios médios por $12,32 \%$, apenas. Entretanto, os municípios dos extremos da classificação, tipo A e tipo $\mathrm{K}$, apesar de contribuírem de maneira significativa ao déficit habitacional total apresentaram cada um apenas seis contratos assinados por meio do programa.

A distribuição dos recursos investidos pelo programa entre as regiões do país, com exceção da região Norte, ocorreu de forma mais equilibrada, sendo que as regiões Sul e

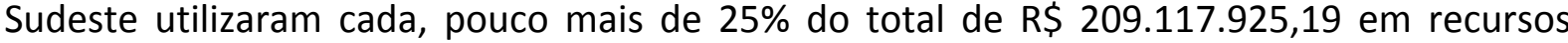
aplicados. Isso mostra que apesar de poucos contratos firmados na Região Sudeste, estes demandaram mais investimentos do FDS do que os contratados pela região sul. Ao analisarmos os recursos distribuídos pelos estados notamos que Goiás ( $R \$ 37.237 .820,00)$ foi estado que mais recebeu recursos do Programa, seguido pelo estado de Minas Gerais ( $R \$ 28.955 .140,00)$, Rio Grande do Sul (R\$26.740.380,00), Santa Catarina (R\$22.559.210,00), e São Paulo (R\$21.827.050,00).

A aplicação dos recursos do Programa ficou concentrada, assim, nos municípios dos cinco primeiros tipos pertencentes às regiões metropolitanas e nos municípios com mais de 100 mil habitantes, e entre estes os municípios do tipo $A$ foram os que receberam o menor

autogestionaria de habitações por meio de programa da prefeitura. Somados a isso existia uma demanda reprimida do Orçamento Participativo da Habitação, e ainda, segundo SOUZA (2007), uma prefeitura parceira que apoiou às associações e desenvolveu convênios com grupos de profissionais e universidade para elaboração de diversos projetos de forma participativa para pleitear recursos do Programa Crédito Solidário.

${ }^{15}$ Pequenos municípios em espaços rurais prósperos e consolidados distribuídos de forma preponderante pelos estados do Sul, Sudeste e parte do Centro-oeste.

${ }^{16}$ A FJP considera que cerca de $1 / 3$ (um terço) das famílias conviventes não representa Déficit Habitacional, pois moram juntas por opção, e outros $1 / 3$ apresenta baixa expectativa de mudar de quadro. 
investimento. Ao lado disso, aos municípios médios e pequenos foram destinados menos de 15\% do montante total de recursos do PCS entre 2005 e 2007.

Gráfico 9

Montante de Recursos do PCS (2005-2007) distribuidos por Região

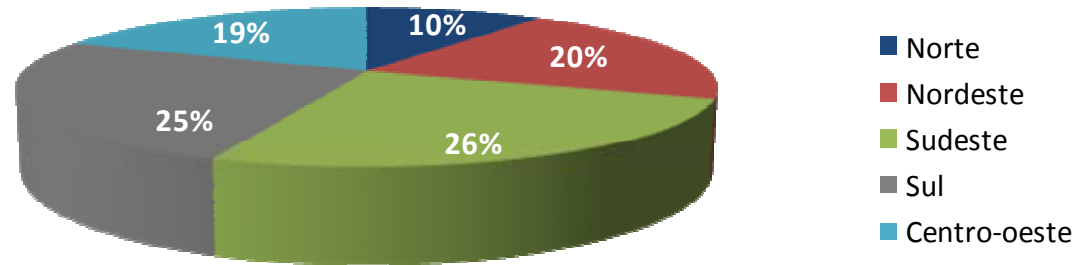

Elaboração própria

fonte de dados: www.cidades.gov.br

Considerando as especificidades de cada modalidade de atendimento habitacional do programa, a distribuição percentual de atendimentos habitacionais por região se deu de maneira mais equilibrada. As regiões que viabilizaram maior percentual de atendimentos habitacionais foram as regiões Sul e Nordeste do país, com $28,86 \%$ e $23,9 \%$ respectivamente do total de 12.199. Os estados de Goiás e Rio Grande do Sul se destacaram em relação aos números absolutos de unidades, respectivamente com 1.943 e 1.782 atendimentos habitacionais. Os municípios dos tipos B, C, D e E foram os mais beneficiados em números de atendimentos habitacionais, somando pouco mais de $70 \%$ da produção habitacional total pelo do PCS.

\section{Gráfico 10}

Atendimentos habitacionais do PCS (2005-2007) distribuidos por Região

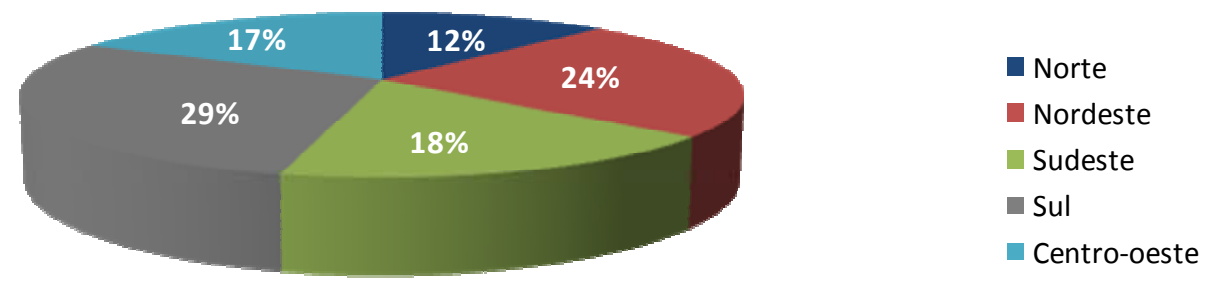

Elaboração própria

fonte de dados: www.cidades.gov.br

A análise comparada entre números de contratos assinados, recursos aplicados e unidades habitacionais produzidas, distribuídos pelas regiões do Brasil e pelas tipologias de 
municípios do PLANHAB, nos ajuda a verificar dados mais significativos, especialmente em relação aos valores dos investimentos e os atendimentos habitacionais.

Gráfico 11

Programa Crédito Solidário (2005-2007) distribuido por tipologia de municípios do PLANHAB

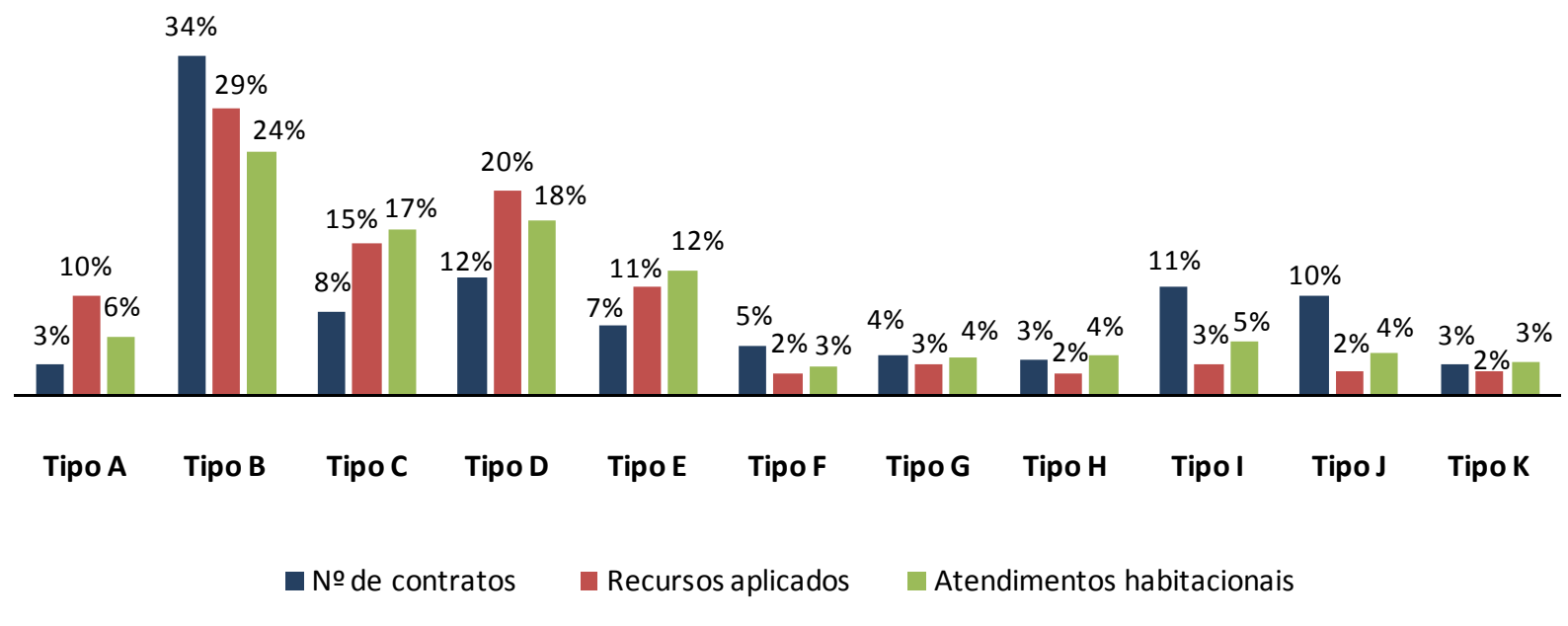

Elaboração própria

fonte de dados: www.cidades.gov.br

Os municípios dos tipos A, B e D proporcionalmente aos atendimentos habitacionais demandaram investimentos maiores. Enquanto os tipos $\mathrm{C}$ e $\mathrm{E}$ (municípios pertencentes às regiões metropolitanas e aglomerados urbanos espalhados no Norte e Nordeste) apresentaram proporção inversa, demandando menores investimentos para produção de unidades habitacionais.

O mesmo ocorreu em relação aos municípios tipo I e J, que apesar de se destacarem por concentrar juntos mais de $20 \%$ dos contratos assinados, não utilizaram mais que $5 \%$ dos recursos investidos, produzindo menos de $10 \%$ das unidades habitacionais realizadas pelo PCS, demonstrando que esses contratos atenderam poucas unidades habitacionais por empreendimentos, e ainda, que demandaram custos menores para a produção do que outras regiões do país.

No âmbito regional o Sul do país apesar de ter firmado mais de $50 \%$ dos contratos, apresentou apenas uma sutil diferença do percentual de unidades habitacionais produzidas entre todas as regiões (com exceção da região Norte). Somados a isso, ao analisarmos as modalidades contratadas, percebemos que todos os contratos das modalidades reforma, 
ampliação e conclusão de unidade habitacional (19 contratos) e aquisição de material de construção (34 contratos) foram feitos por municípios do Sul do país, sendo que grande parte desses ocorreram em pequenos municípios (15 e 27 contratos respectivamente), de territórios rurais as quais apresentam limites de valores mais baixos por intervenção.

A região Sudeste, por sua vez, foi a região que mais demandou recursos para produção de unidades proporcionalmente aos atendimentos realizados. Podemos apontar a hipótese de que o investimento é maior no Sudeste, principalmente porque o acesso à terra urbanizada é mais restrito do que outras regiões do país, e portanto o custo é mais elevado. Ao lado disso, ocorreu na região Nordeste a situação inversa, onde proporcionalmente, foram aplicados menos recursos do programa em relação ao número de atendimentos realizados.

\section{Gráfico 12}

Programa Crédito Solidário (2005-2007) distribuidos por Região

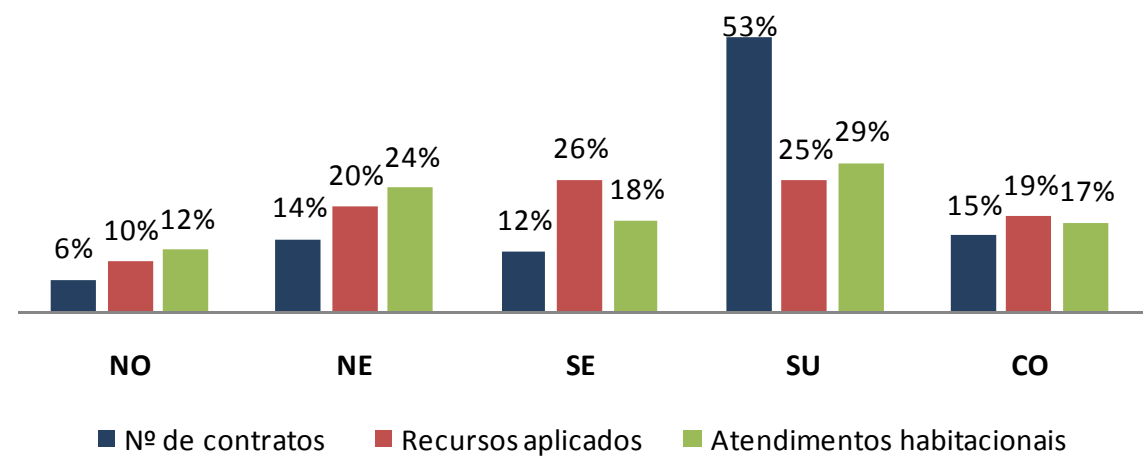

Elaboração própria

fonte de dados: www.cidades.gov.br

Ao introduzirmos a informação do déficit habitacional nessa análise, verificamos que os atendimentos habitacionais realizados pelo PCS não têm respondido proporcionalmente às carências habitacionais caracterizadas e distribuídas pela tipologia de municípios do PLANHAB. Nesta relação os municípios tipo A, que concentram o maior percentual do déficit habitacional urbano e ainda os tipos $\mathrm{J}$ e $\mathrm{K}$ que concentram o déficit habitacional rural, proporcionalmente apresentaram os menores números de atendimentos habitacionais pelo PCS. 
Distribuição dos percentuais do déficit habitacional urbano (2006) $X$ atendimentos habitacionais do PCS (2005-2007), por tipo de município do PLANHAB.

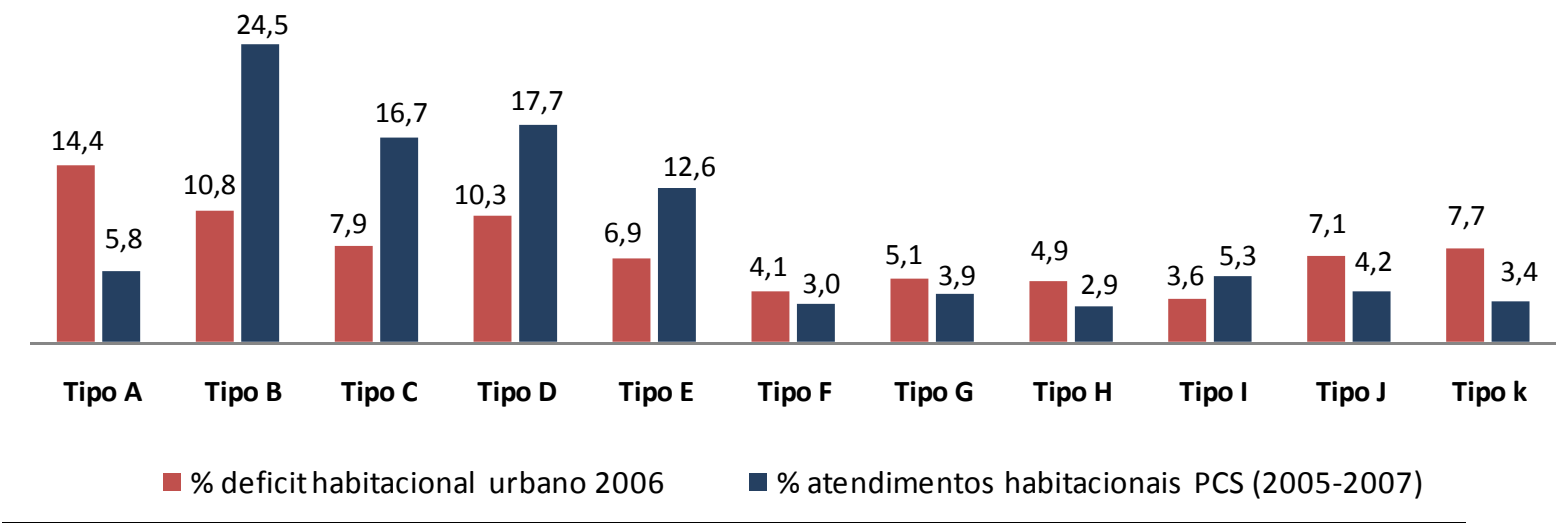

Elaboração própria

fonte de dados: (BRASIL/MINISTÉRIO DAS CIDADES/ SECRETARIA NACIONAL DE HABITAÇÃO/ CONSÓRCIO PLANHAB, 2009) e www.cidades.gov.br.

E por fim, ao analisarmos o gráfico a seguir percebemos que a distribuição dos investimentos em habitação realizados pelo governo federal entre 2003 e 2007 acompanharam, em linhas gerais, os percentuais do déficit habitacional distribuídos pelas regiões do país. Entretanto, é possível notar que os investimentos realizados pelo PCS diferem dessa diretriz, mesmo sendo parte integrante da Política Nacional de Habitação. Apesar das metas estabelecidas pelo Conselho Curador do FDS (CCFDS) seguirem as mesmas regras de distribuição regional dos demais investimentos em habitação realizados pelo governo federal - baseado na proporcionalidade do déficit habitacional - as dificuldades de efetivação do programa levam a uma "redistribuição natural" em função dos contratos efetivados. Segundo Ramos, gestor do programa do Ministério das Cidades ${ }^{17}$, quem "...consegue superar a corrida de obstáculos a gente contrata." independentemente da distribuição regional, ou da distribuição percentual das metas definidas pelo CCFDS.

\footnotetext{
${ }^{17}$ Em entrevista realizada com César Ramos em 13 de fevereiro de 2008.
} 
Distribuição dos percentuais do déficit habitacional (2006) X investimentos federais em habitação (2003-2007) X investimentos do PCS (2005-2007), distribuidos por região

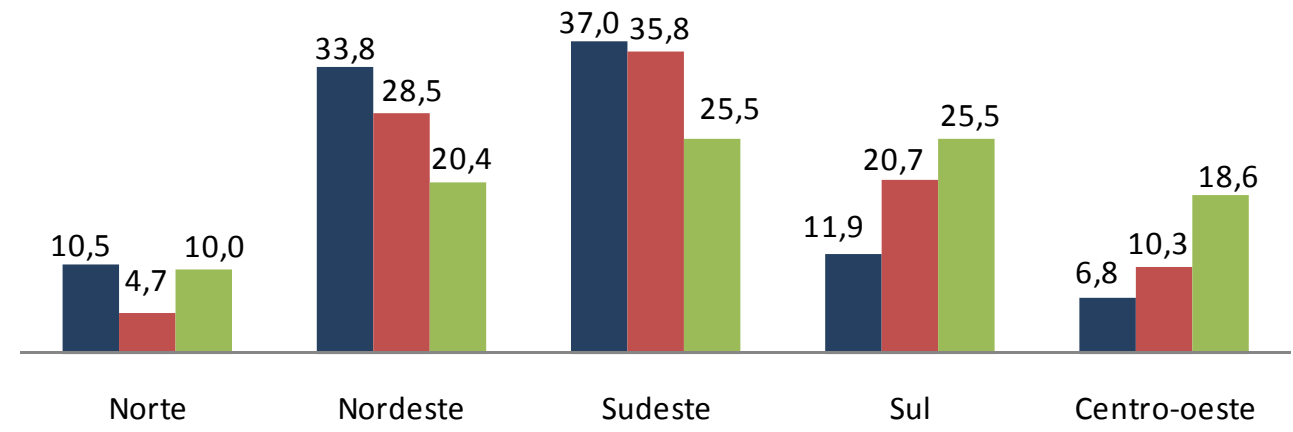

— deficit habitacional (2006) — Investimento em habitação (2003-2007) — Investimentos do PCS (2005-2007)

Elaboração própria

fonte: www.cidades.gov.br e (BRASIL/MCID/SNH, 2008).

Quantitativamente verificamos que o total de atendimentos viabilizados pelo Crédito Solidário nos três anos de operação (2005 - 2007) representa menos de $1 \%$ do total de atendimentos viabilizados pelos recursos públicos do governo federal entre 2003 a $2007^{18}$, e é quase irrisório para o enfrentamento efetivo do déficit habitacional. Em relação às características das necessidades habitacionais, o Programa reponde a uma "agenda invertida", já que foram poucos os empreendimentos contratados nas regiões metropolitanas e aglomerados urbanos, onde se concentra o maior percentual do déficit habitacional. E, por outro lado, respondeu bem à realidade dos pequenos municípios do Sul e Goiás, onde a demanda por novas habitações não é tão latente.

Considerando a caracterização dos resultados do Programa, que demonstra principalmente o impacto irrisório - seja pela quantidade de recursos investidos quanto em relação ao foco de intervenção para enfrentar o déficit habitacional - qual é a razão que leva o Governo Federal, em manter um programa como o PCS?

Ramos (2008) justificou que "... (o PCS) tem muito mais um efeito demonstrativo, de mostrar possibilidades, do que ser efetivo no enfrentamento do déficit habitacional", buscamos então, identificar esse efeito demonstrativo sugerido. $E$, ao observarmos as fotos

\footnotetext{
${ }^{18}$ Com base nos dados apresentados pelo Ministério das Cidades (BRASIL/MCID, 2008:40) entre o mês de janeiro de 2003 e dezembro de 2007 foi feito o investimento de R\$58,12 bilhões (FGTS, OGU, FNHIS, FAT, FAR, CEF e FDS) para viabilizar o 2,6 milhões de atendimentos habitacionais (aquisição, reforma ou construção de novas moradias), dois quais $79,64 \%$ foram destinados à famílias com renda inferior a cinco salários mínimos.
} 
dos projetos do Crédito Solidário disponibilizadas no site do Ministério das Cidades ${ }^{19}$ ficamos instigados ao percebermos que as características da produção habitacional da maioria deles, salvo exceções, não se diferenciavam dos tradicionais projetos de Habitação de Interesse Social espalhados pelo Brasil, que reproduzem o velho padrão de habitação popular difundido a partir do período BNH.

O modelo de baixa densidade com as unidades habitacionais horizontais idênticas e enfileiradas, com telhado de duas águas, implantadas no meio dos lotes, resultante de uma implantação que segue o padrão urbanístico usual: ortogonal, uniformizado, padronizado e desumanizado. Esse fato nos levou a questionar qual seria o efeito demonstrativo?

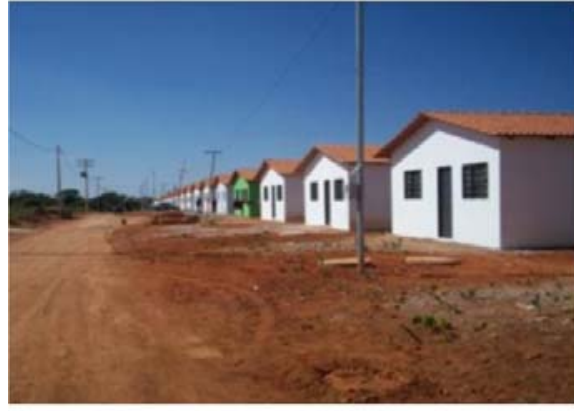

Cidade Ocidental - Goiás: 62 uh fonte: www.cidades.gov.br

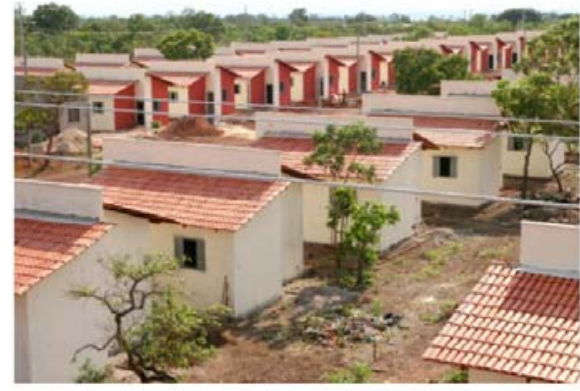

Palmas - Tocantins: 200 uh fonte: Bismarque M.(MNLM)

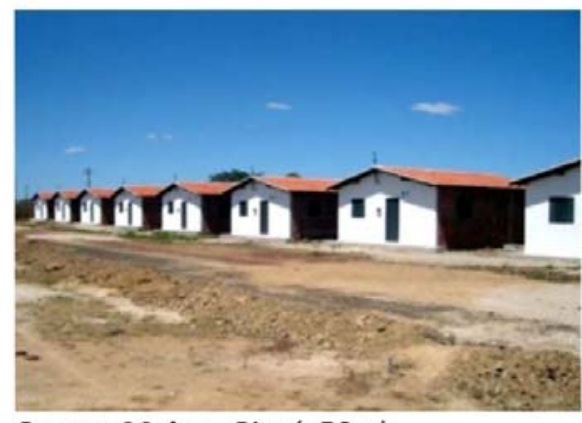

Campo Maior - Piauí: 50 uh fonte: www.cidades.gov.br

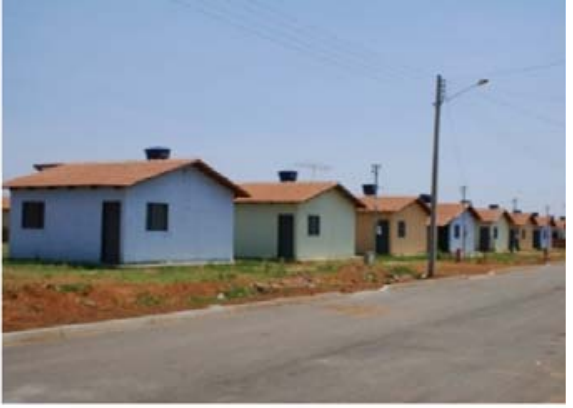

Goiânia - Goiás: 120 uh fonte: acervo pessoal

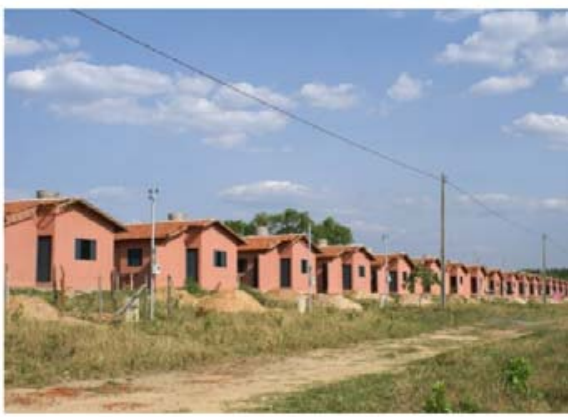

Aparecida de Goiás - Goiás: 200 uh fonte: acervo pessoal

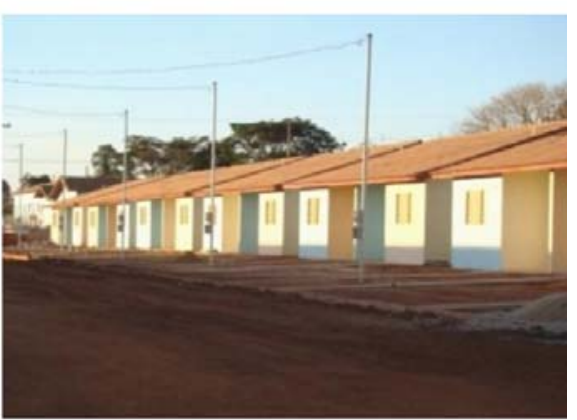

Alfenas - Minas Gerais: 66 uh fonte: www.cidades.gov.br

\footnotetext{
${ }^{19}$ Fotos disponíveis em: http://www.cidades.gov.br/secretarias-nacionais/secretaria-de-habitacao/programase-acoes/credito-solidario/fotos/fotos; acesso realizado em 15 de fevereiro de 2008 e 20 de janeiro de 2009.
} 


\subsection{Crédito Solidário na prática}

O propósito que nos motivou a realizar o trabalho de campo foi a intenção de observar os impasses e possibilidades criados pelo Programa, e principalmente observar a qualidade do fragmento de cidade produzido e sua inserção na malha urbana. Assim, a partir do trabalho de campo foi possível extrair mais elementos para sustentar nossa análise ${ }^{20}$, que até este momento estava sendo realizada com base nas informações obtidas pelas entrevistas e documentos oficiais.

Buscando conhecer realidades diversas, definimos três experiências localizadas nos estados de Goiás, Bahia e São Paulo, que foram efetivadas por diferentes sistemáticas do Programa: a primeira delas, (1) Eldorado Oeste em Goiânia teve sua proposta apresentada ainda na primeira sistemática de 2004, porém foi contratada somente em junho de 2006 após modificações operacionais do PCS; (2) Vila Solidária Mar Azul em Salvador foi pleiteada em 2005 e, somente após solução do impasse decorrente da ocupação do terreno por outras famílias, foi contratado com as regras vigentes em 2007; e (3) Colinas da Oeste em São Paulo foi contratada em 2008 já na atual sistemática (a reestruturação do PCS, que será tratada com mais cuidado adiante) depois de dois anos para vencer as tratativas iniciais do processo.

Os três empreendimentos foram organizados por associações vinculadas às entidades estaduais da União de Moradia Popular, que por sua vez são parte integrante da União Nacional de Moradia Popular (UNMP). A entidade nacional garante a autonomia de ação entre os movimentos que a compõe, por tratar-se de uma federação de movimentos de moradia que são heterogêneos entre si tanto na forma de organização, quanto nas dinâmicas de atuação, táticas de reivindicações e abrangência ${ }^{21}$. E talvez por isso, apesar da autogestão estar presente como uma das principais bandeiras de luta deste movimento, ela se materialize de diferentes maneiras por cada um deles.

Outras razões que permearam a escolha das experiências foram as especificidades de cada uma delas. Goiás, por exemplo, foi o estado que mais se destacou em números de

\footnotetext{
${ }^{20}$ Vale reafirmar, que não foi definido como propósito da pesquisa realizar uma avaliação do Programa Crédito Solidário, e sim uma análise do processo de apropriação do princípio da autogestão na política habitacional do Governo Lula.

${ }^{21}$ Informações extraídas do site: http://www.unmp.org.br, acesso realizado em 05 de janeiro de 2009.
} 
atendimentos habitacionais contratados e também no total de recursos pleiteados, o que nos motivou a conhecer algumas de suas experiências ${ }^{22}$.

A escolha de São Paulo ocorreu justamente com o propósito de compreender as razões que têm dificultado a contratação de empreendimentos nas Regiões Metropolitanas, em especial na capital ${ }^{23}$, apesar do aparente contexto favorável. Na nossa concepção esse contexto favorável estaria justificado pelo fato de ter ocorrido lá as primeiras experiências de autogestão na produção habitacional e, em decorrência do Programa FUNACOM, ter-se consolidado o "modos operante" que se perpetua ainda hoje em alguns honrosos projetos ${ }^{24}$ financiados pelos governos municipal e estadual, no qual o movimento popular organizado e a assessoria técnica continuam atuando em parceria.

Já a experiência de Salvador, apesar do município não ter tradição de desenvolver empreendimentos autogeridos, nos chamou atenção. Isso porque a defesa do Programa foi feita pela, então secretária de habitação do município, que considerando os limites da gestão pública, afirmou que por meio do PCS e proporcionando apoio financeiro e institucional ao movimento organizado, seria a maneira mais rápida de conseguir efetivar a construção de empreendimentos habitacionais com qualidade. O partido urbanístico e arquitetônico elaborado, também foi outro fator que nos chamou a atenção por se diferenciar dos padrões tradicionais de HIS.

Certamente outras experiências poderiam ser objeto desse trabalho de campo, e nos mostrariam outros tantos aspectos interessantes próprios da realidade do município, da postura da CEF local e da peculiaridade do grupo, como exemplo da experiência de Ponta

\footnotetext{
${ }^{22}$ Além do empreendimento Eldorado Oeste de Goiânia, sistematizado no Quadro 04 dos empreendimentos visitados, conhecemos mais três experiências. Duas delas em Goiânia: Residencial Lírios do Campo (120uh) da Associação Morar Bem vinculado à CONAM e o empreendimento pleiteado pelo Movimento de Luta pela Casa Própria (137uh), ambos apresentam o mesmo projeto, com unidade habitacional de $42 \mathrm{~m}^{2}$ e foram realizados por uma empreiteira contratada. E o terceiro no município de Aparecida de Goiás, coordenado pelo Movimento das Donas de Casa (MDC) com 200 unidades habitacionais com $39 \mathrm{~m}^{2}$ de área útil.

${ }^{23}$ Até o final de 2008 apenas sete empreendimentos do PCS foram contratados na capital paulista.

${ }^{24}$ Pois nesses governos são enfrentadas diversas dificuldades para efetivar os projetos habitacionais produzidos por autogestão. Após o Funaps-Comunitário não existiu outro programa em São Paulo que de fato buscasse apoiar e viabilizar esse tipo de ação, que só existe ainda em função da pressão imposta pelo movimento.
} 
Porã no Mato Grosso do Sul ${ }^{25}$, ou de Palmas no Tocantins ${ }^{26}$, bem como a de São Luís no Maranhão ${ }^{27}$, ou ainda dos empreendimentos de Belo Horizonte ${ }^{28}$, dos casos de cooperativas rurais do Rio Grande do Sul e Santa Catarina ${ }^{29}$, do centro de Porto Alegre ${ }^{30}$, da experiência do Rio de Janeiro ${ }^{31}$, como outros mais. Infelizmente não foi possível abarcar outras realidades, e em função dos limites temporais e financeiros, optamos então pelas três experiências que seguem sistematizadas abaixo.

\subsubsection{Os empreendimentos visitados}

Decidimos apresentar os empreendimentos visitados em três quadros (a seguir) com o propósito de sistematizar as informações apreendidas em cada um deles e permitir um olhar descritivo e comparativo.

25 Coordenada por Edymar Cintra, liderança do MNLM, que vem utilizando a Tecnologia Beno nos empreendimentos e tem realizado autogestão por meio de outros programas como a Resolução 460 do Governo Federal e o Che Roga Mi do governo do estado do Mato Grosso do Sul.

${ }^{26}$ Coordenada por Bismarque Miranda também liderança do MNLM. A experiência foi marcada por muita pressão para conquistar a parceria com o governo do estado de Tocantins e a prefeitura de Palmas que viabilizaram terreno, investimentos em equipamentos públicos e infra-estrutura. O movimento conta ainda com a parceria com Universidades (Federal e particular: UBRA) e com escolas técnicas para o apoio técnico e em atividades com as comunidades no desenvolvimento de trabalhos de formação do grupo, incentivando o processo de participação desde a discussão dos projetos às obras em mutirão, que ainda representa grande peso da mão-de-obra.

${ }^{27}$ Experiência coordenada por Creuzamar Pinho, da UNMP, e de outras entidades que demonstraram que o movimento popular tem conseguido contratar recursos do Crédito Solidário, enquanto $70 \%$ dos recursos (de outros programas) empenhados pelo Ministério das Cidades não são gastos pelo poder público, pois estes não conseguem desenvolver projetos adequados e montar um contrato, conforme destacado por César Ramos.

${ }^{28}$ Coordenados por Antônia de Pádua da CMP e Ênio Nonato da CONAM esses empreendimentos receberam o apoio da prefeitura e de profissionais que desenvolveram projetos para terrenos que haviam sido destinadas às famílias dos movimentos populares pelo Orçamento Participativo de Habitação, mas que até então não tinham recursos para viabilizar a construção das unidades habitacionais.

${ }^{29}$ Empreendimentos que caracterizam a maioria dos contratos realizados no sul do país.

${ }^{30}$ Caso do MNLM do Rio Grande do Sul que contratou recursos do PCS para reformar prédio do INSS ocupado durante o Fórum Social Mundial no centro de Porto Alegre para abrigar 42 famílias, construir um teatro de arena e restaurante comunitário, onde em parceria com o MST serão desenvolvidos projetos de compra direita de alimentos, e que segundo César Ramos, trata-se de um dos bravos e honrosos casos excepcionais de qualidade promovidos pelo PCS.

${ }^{31}$ A Fundação Bento Rubião desenvolveu o projeto habitacional para PCS em parcerias com a União por Moradia Popular do estado do Rio de Janeiro, por meio de apóio técnico e social. A proposta foi contratada em dezembro de 2007, está localizada em Jacarepaguá, área onde a Fiocruz tem encabeçado processo de regularização fundiária, e cujo terreno da União foi alienado à Prefeitura para viabilização do PCS. 


\section{Quadro 4}

\section{Trabalho de Campo | Empreendimento Eldorado Oeste I | Eldorado Oeste, Goiânia - GO Associação responsável: União Estadual de Moradia Popular - GO}

\section{Antecedentes}

Em Goiânia o movimento de moradia, desde o final da década de 70 se mostrava aguerrido, e realizou diversas ocupações de terras coletivas reivindicando ações concretas do poder público. A Vila Mutirão tornou símbolo da ação do Estado em resposta às reivindicações populares. A UEMP-GO após anos de luta passou a reivindicar do poder público a regularização das áreas ocupadas e a produção de novas unidades habitacionais. Assim como demais movimentos da cidade (Movimento Metropolitano de Moradia-GO, Movimento por Reforma Urbana, Cooperativa de Luta pelo Lote) tem realizado por inciativa própria empreendimentos autofinanciados e construídos em mutirão.

\section{Empreendimento}

O empreendimento Eldorado Oeste com 450uh é composto por três fases de obra com 150 unidades habitacionais. As duas primeiras foram pleiteadas pela UEMP-GO na primeira sistemática de 2004. Após adaptações a fase I foi contratada em junho de 2006 e a fase II em novembro do mesmo ano, e encontram-se concluídas. A fase III foi contratada em novembro de 2007 e no momento do trabalho de campo (15 de outubro de 2008), a obra estava na fase de conclusão da alvenaria.

\begin{tabular}{|c|c|c|c|c|}
\hline Valores & & VF (FDS)/UH & CP \$/UH & M.O.MUT./UH \\
\hline & \multirow{3}{*}{$\begin{array}{l}\text { Eldorado Oeste I } \\
\text { (150 uh) }\end{array}$} & $\mathrm{R} \$ 18.685,52$ & $\mathrm{R} \$ 1.250,00$ & $\mathrm{R} \$ 2.614,48$ \\
\hline & & VI/UH & VF (FDS) OBRA & VI OBRA \\
\hline & & $\mathrm{R} \$ 22.550,00$ & $\mathrm{R} \$ 2.802 .828,00$ & $R \$ 3.352 .500,00$ \\
\hline
\end{tabular}

A associação não recebeu qualquer tipo de apoio do poder público local. Todas as extensões das redes de infraestrutura foram executadas com os recursos do PCS. E o investimento inicial referente a elaboração do projeto, taxa de aprovação na prefeitura e outras despesas foram pagas pela contrapartida financeira das famílias em $\mathrm{R} \$ 1.250,00$. Somada ao valor equivalente da mão-de-obra mutirante (que representou $11,6 \%$ do $\mathrm{VI}$ ) totalizou $\mathrm{R} \$$ $3.865,00$. A contrapartida total representou $17 \%$ do Valor do Investimento. Somente as taxas referentes ao habite-se foram isentadas por decreto. Após o empreendimento concluído a prefeitura alugou uma casa do loteamento, onde passou a funcionar uma Unidade Básica de Saúde e está construindo uma escola de ensino fundamental para atender a nova demanda.

\section{Terreno}

Após procura de terrenos viáveis as famílias optaram pelos 225 lotes de $360 \mathrm{~m}^{2}$, regularizados, servidos com infra-estrutura básica do loteamento Eldorado Oeste, localizado no extremo oeste da cidade, no valor de R\$ $12.000,00$ cada (cerca de $\mathrm{R} \$ 33,00 / \mathrm{m}^{2}$ ). A aquisição da terra foi feita com os recursos do Crédito Solidário.

Projeto

O projeto apresenta uma única tipologia com dois quartos, sala, cozinha, wc e área de serviço externa, com $46,6 \mathrm{~m}^{2}$. São geminadas e implantadas no centro do lote que foi dividido e registrado como condomínio com duas frações ideais de $180 \mathrm{~m}^{2}$. O projeto foi desenvolvido por uma arquiteta contratada, que após a conclusão do projeto fez uma apresentação para as famílias. Segundo Vidal, não havia muitas alternativas de modificações, em função das características do terreno,e foram alterados somente pequenos aspectos, como lugar da pia (voltado para a janela) e o tipo da caixa d'água.

\section{Garantia \\ Alienação fiduciária}

\section{Equipamento Comunitário}

O centro comunitário/galpão de obra provisório foi construído em área pública. Atualmente o movimento está negociando a permanência desse espaço como equipamento para a comunidade. 


Sistema Construtivo
$\quad$ Foi adotado o sistema construtivo de alvenaria tradicional.
Acompanhamento da Obra

Além da presença na obra da arquiteta $3 \times$ por semana (pacote de $\mathrm{R} \$ 36.000,00$ divididos $\mathrm{R} \$ 3.000,00$ por mês e mais $\mathrm{R} \$ 4.000,00$ pelo projeto), o acompanhamento da obra foi realizado por um engenheiro contratado que recebeu $\mathrm{R} \$ 2.500,00$ por mês por 3 horas de trabalho/ dia.

\section{Gestão/ execução da obra}

A gestão financeira foi realizada por uma das moradoras. A execução da obra durou 1 ano e o trabalho em mutirão acontecia em 3 finais de semana/mês. Nas fases I e II, foram contratados mão-de-obra apenas para os serviços especializados, já na fase III decidiu-se que durante a semana a obra seria executada por empreiteira contratada. A administração direta da obra feita pela associação, no contexto positivo da economia brasileira, possibilitou na fase I otimizar os recursos e utilizar parte dele no acabamento externo e acrescentar cerâmica das áreas molhadas (não previstos no orçamento original aprovado). Na fase II, pela demora da liberação dos recursos, o mesmo orçamento não foi suficiente para fazer o mesmo tipo de acabamento. Já na fase III, mesmo com um orçamento um pouco maior ( $R \$ 20.000,00 / u h)$, existe a preocupação de que não seja suficiente para conclusão da obra.

\section{Seleção/ perfil das famílias}

A seleção das famílias foi feita a partir do grupo inicial de associados que freqüenta as reuniões mensais da UEMP. Após divulgação do programa, para a primeira etapa formou-se grupo de 250 nomes selecionados conforme critério de pontuação e encaminhados a CEF. Após a análise de crédito à CEF selecionou um grupo de 220, e por fim, realizou-se sorteio para tirar as 150 famílias. Para as demais fases a seleção foi mais simples, pois o numero do grupo era proporcional ao número de unidades habitacionais. O perfil das famílias é caracterizado por uma renda média de $\mathrm{R} \$ 600,00$ e faixa etária de 35 anos.

Trabalho Social

O trabalho social foi desenvolvido por uma assistente social e duas estagiárias, pagos também pela contrapartida das famílias. Segundo relato dos moradores foram desenvolvidas atividades educativas em relação a importância da reciclagem, como cuidar dos resíduos sólidos, palestras sobre educação sexual e economia solidária. Foram realizadas visitas em outros empreendimentos em Caldas Novas e em Goiânia como os bairros Real Conquista (produzido pelo governo do estado), Senador Canedo e João Paulo II (realizados por autofinanciamento e mutirão).

\section{Relação com CEF}

A boa interlocução com CEF possibilitou (1) que a associação após a assinatura dos contratos individuais ficasse responsável por guardá-los, para evitar desgastes com as famílias durante a obra, (2) a exclusão das famílias que não estivessem participando da obra, ocorrendo a subistituição de 13 famílias. Em relação a fase III do empreendimento para contornar a defasagem do orçamento, a associação vem negociando com a CEF e Ministério a possibilidade de se fazer uma suplementação de recursos, já que não se prevê aditivo, como nos casos de financiamentos entre CEF e municípios, por exemplo. O problema caso ocorra suplementação de recursos, será preciso reajustar o valor do financiamento individualizado consequentemente as famílias terão que apresentar uma renda um pouco maior para poder arcar com o recurso adicionado. Considerando que existam famílias que não tenham capacidade de endividamento maior, essas não poderão receber esses recursos, interferindo no processo como um todo.

\section{Particularidades}

Segundo moradora Valdora, o prazo de financiamento foi definido em 18 anos e meio, a parcela de amortização paga mensalmente estava em $\mathrm{R} \$ 98,00$ (out/2008) e seus custos com água e luz eram aproximadamente $R \$ 15,00$ cada. Antes, quando morava de aluguel pagava cerca de $R \$ 200,00$ por mês, mais em média $R \$ 30,00$ com as contas de água e de luz. Apesar de achar que o tranalho foi muito intenso, fez elogios a prática do mutirão como processo de construção de vinculo entre moradores. 


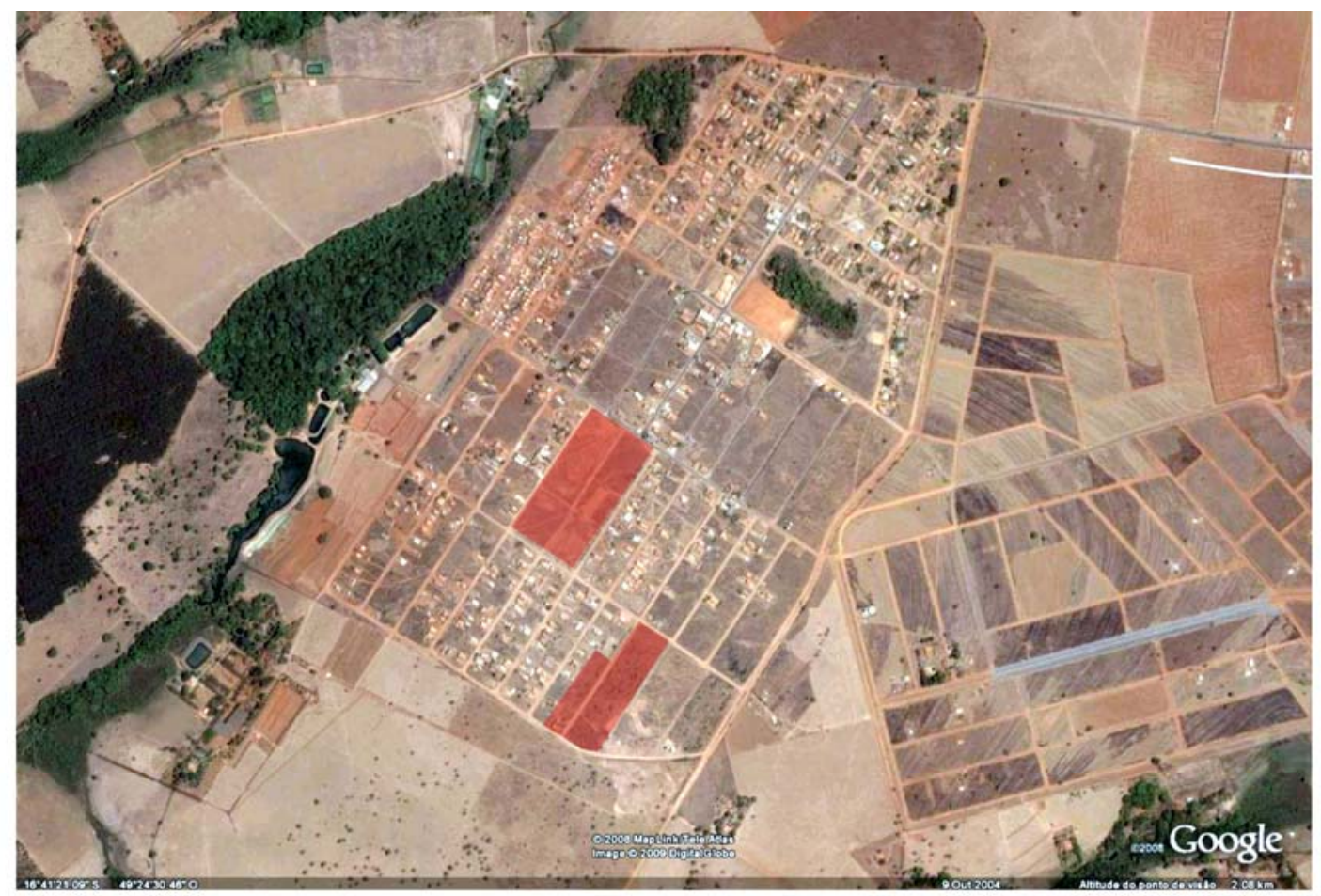

Localização do empreendimento na malha urbana

Fonte: Google Maps



Planta tipo do empreendimento Escala: 1:200

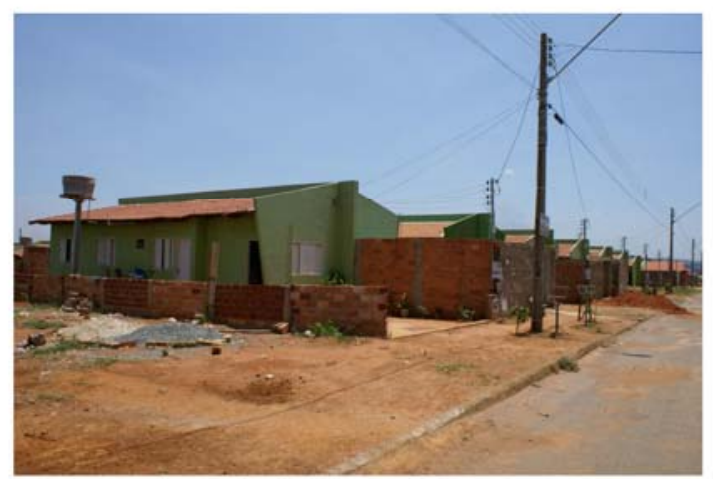

Fotos do empreendimento Fase I e Fase II Fonte: Acervo próprio

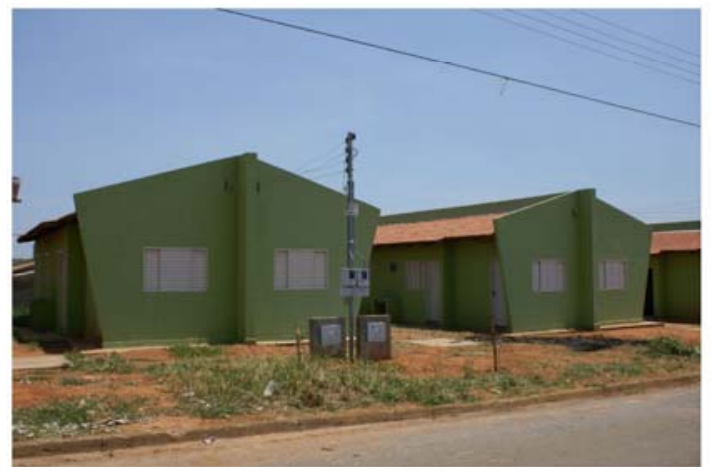

Foto do empreendimento

Fonte: Acervo próprio

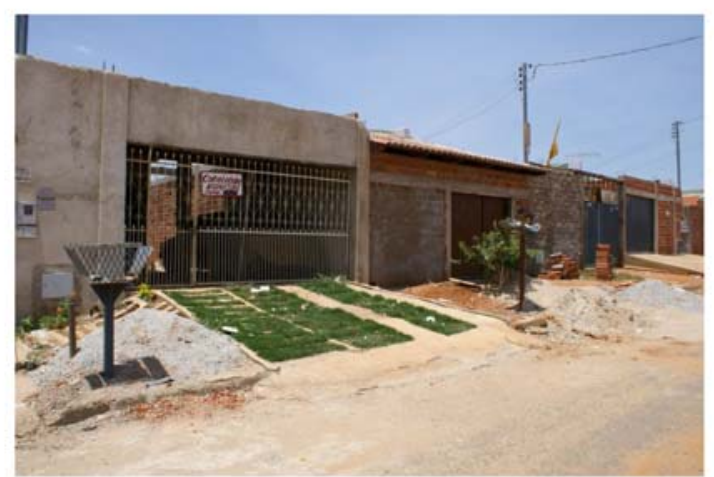




\title{
Quadro 5
}

Trabalho de Campo | Empreendimento Vila Solidária Mar Azul | Paripe, Salvador - BA Associação responsável: Associação de Moradores de Gameleiras e Adjacências

\begin{abstract}
Antecedentes
No início dos anos 40 ocorreram as primeiras ocupações coletivas de terra (GORDILHO-SOUZA, 1997). E apesar da repressiva atuação do Estado, foram iniciativas que se reproduziram ao longo dos anos. Nos anos 70/80 esses movimentos passaram a se organizar em torno de associações de moradores e congregações articuladas localmente. Nos anos 90 quando ocorreu forte retração da ação pública tanto na recurperação de áreas degradadas como na produção habitacional e demais ações sociais, percebeu-se o surgimento de ONGs atuando tanto em ações de desenvolvimento comunitário, quanto em intervenções na área habitacional como exemplo de Novos Alagados. Em 1999, foi criada a União de Moradia Popular da Bahia pela reunião de diversas associações de bairros populares, com o propósito de criar um movimento social forte para apoiar as ações e reivindicações dos bairros. A UMP-BA é vinculada à UNMP, ao FNRU e à CMP, tem como objetivo a busca por alternativas para implantação de políticas de HIS articulando movimentos, entidades em diferentes níveis, públicas e privadas para viabilizar, "principalmente sob forma de cooperativas habitacionais, empreendimentos solidários sob regime de mutirão e autogestão popular"*.
\end{abstract}

Empreendimento

Em agosto de 2006 foi assinado o primeiro contrato do PCS no município de Salvador para construção de 200 unidades habitacionais, resultado da iniciativa da Associação de Moradores da Gameleira e Adjacências vinculada à UMP-BA em parceria com a Secretaria de Habitação da Prefeitura. Dias depois da assinatura do contrato, o terreno foi ocupado por outras famílias. Após mais de um ano de negociações, por intermédio do governo do estado, foi possível chegar a um acordo, e somente em novembro de 2007 foi assinado o novo contrato contemplando $236 \mathrm{UH}$, para atender além das famílias da AMGA, mais 50 famílias do grupo que desocupou a área. No momento do trabalho de campo (24.agosto.2008), cerca de $40 \%$ da obra havia sido executada.

\begin{tabular}{|c|c|c|c|c|}
\hline Valores & & VF (FDS)/UH & COMPL. \$ SECOMP/UH & COMPL. \$ PMS/UH \\
\hline & Paripe (236 uh) & $\mathrm{R} \$ 16.083,21$ & $R \$ 5.000,00$ & $R \$ 902,58$ \\
\hline & M.O.MUT/UH & VI/UH & VF (FDS) OBRA & VI OBRA \\
\hline & $\mathrm{R} \$ 1.416,60$ & $\mathrm{R} \$ 23.402,39$ & $R \$ 3.795 .637,56$ & $R \$ 5.309 .813,56$ \\
\hline
\end{tabular}

Em 2005,a secretária de habitação, Ângela Gordilho, resolve fazer uma parceira com as associações que enviaram propostas do PCS. Todos os processos de aprovação de projeto foram acompanhados pela SEHAB, bem como negociações feitas junto às concessionárias de serviços urbanos e CEF. Para o desfecho do impasse da ocupação, o governo do estado entrou com aporte de $\mathrm{R} \$ 1.180 .000,00$ da Secretaria de Combate à Pobreza e às Desigualdades Sociais (SECOMP) destinados a execução da IE do conjunto e complementação do valor da UH, somados ao valor financiado pelo PCS. A contrapartida realizada pela Prefeitura contou com a desapropriação do terreno (única ação quantificada em $\mathrm{R} \$ 213.008,53$ ), apoio técnico, social e institucional viabilizado pela Secretaria de Habitação (negociação para desapropriação da área, e posterior reintegração das famílias que ocuparam o terreno após a assinatura do PCS, cadastramento das famílias, a aprovação do projeto, negociação com CEF , entre outros), elaboração do projeto e construção do centro comunitário (valor não computado). As famílias não entraram com contrapartida financeira e deverão contribuir com mão-de-obra mutirão no valor que corresponde a $30 \%$ de toda mão-de-obra estimada $(\mathrm{R} \$ 334.316,73)$. A contrapartida total por família representa cerca de $6 \%$ do VI.

O terreno do Paripe, localizado no estremo noroeste de Salvador, encontra-se no final do vetor de crescimento popular do suburbio ferroviário, ocupado por loteamentos populares a partir dos anos 40 . Região caracterizada pela concentração de habitações precárias e ausência de serviços, infra-estrutura e equipamentos urbanos. 0 terreno foi desapropriado pela prefeitura no valor de $\mathrm{R} \$ 213.008,53$. (Decreto $15.577 \mathrm{de} 29 / 03 / 05$ é de $39.183,94 \mathrm{~m}^{2}$ e a área referente à projeção das UHs $\left(9.700,00 \mathrm{~m}^{2}\right)$ foi doada à Associação, e para a contratação do PCS foi feita a incorporação do imóvel. O restante do terreno ficou como área de domínio público com uso fruto da Associação.

O projeto doado à Associação foi desenvolvido por um grupo de alunos da UFBA ainda em 2001, e a Associação que já conhecia o primeiro projeto, anos depois os procurou pra solicitar o uso do projeto com as adaptações necessárias para que fosse implantado no novo terreno. O grupo apresentou para as famílias o projeto e o partido adotado de UHs sobrepostas, destacando a importância das áreas coletivas, a disposição e criação de espaços coletivos em volta das unidades e os quintais e terraços em função das pequenas dimensões das unidades. Trata-se de um condomínio com 118 lotes de $40,76 \mathrm{~m}^{2}$ a $85,5 \mathrm{~m}^{2}$, que abrigam duas unidades habitacionais sobrepostas de $32,9 \mathrm{~m}^{2}$ de área útil e $42,7 \mathrm{~m}^{2}$ de área construída, com dois quartos, sala, cozinha, wc e área de serviço externa. Soma-se à unidade de baixo um quintal, e à unidade de cima um terraço. Considerando o baixo limite do financiamento, foi previsto a ampliação posterior de $50 \%$ da área dos quintais e terraços. 
Garantia

Alienação fiduciária

Equipamento Comunitário

A prefeitura foi responsavel pela elaboração do projeto e construção do Centro Comunitário, primeira etapa da obra concluída.

Sistema Construtivo

Foi adotado pelo engenheiro que faz o acamanhamento da obra o sistema construtivo pré-moldado com as peças feitas e montadas no canteiro, com o propósito de baratear e simplificar a obra.

Acompanhamento da Obra

A obra começou em fevereiro de 2008, com previsão de 12 meses de duração. 0 acompanhamento é feito por engenheiro contratado que afirmou que "Quem faz a gestão da obra são os próprios proprietários, eu não faço a gestão eu só faço um planejamento".**

\section{Gestão/ execução da obra}

Foi previsto o uso de $30 \%$ de mão de obra mutirante, porém em média têm ocorrido $10 \%$ apenas. Avaliação do Eng. é que tem faltado trabalho social para estimular maior motivação e participação no mutirão. Segundo Ana*** (comissão gestora) os problemas com a participação no mutirão tem ocorrido principalmente com as famílias do grupo de ocupantes que entraram no meio do processo, e por informações erradas fornecidas pela própria CEF. Ao afirmar às famílias que não são obrigadas à participar do mutirão a CEF rompe com a autonomia do grupo e contraria o regulamento de obras aprovado coletivamente. O mutirão funciona todos os dias, mas principalmente nos finais de semana. É preciso cumprir 16h semanais que são registradas e controladas e é permitido levar parentes e amigos para complementar as horas de trabalho. Durante a semana tem uma equipe contratada, composta também por alguns beneficiários, que toca a obra.

\section{Seleção/ perfil das famílias}

A formação do grupo iniciou com as famílias participantes das ações do movimento, entretanto foi preciso ampliar para a população em geral, pois poucas famílias conseguiram ser enquadradas nos critérios do programa. A Associação recebeu apoio da prefeitura para realizar a organização do grupo, coletar documentação a ser apresentada na CEF, e ainda viabilizou apoio técnico social prévio à contratação da proposta. Cerca de $70 \%$ do grupo é composto por mulheres, a renda média familiar gira em torno de $\mathrm{R} \$ 600,00$.

\section{Trabalho Social}

Trabalho social ocorre desde 2006 com o acompanhamento das assembléias do grupo, um estímulo para as famílias se conhecerem. Foram feitas discussão sobre o trabalho em mutirão, elaboração e aprovação do regulamento de obras. Ao longo da obra tem se definido novas necessidades a serem trabalhadas a exemplo da formação de uma creche, respondendo às mulheres, que justificam sua ausência por não ter onde deixar as crianças pequenas. $O$ grupo teve apoio de integrantes do E-changer (ONG francesa) e integrantes a UMM-SP. O engenheiro que acompanha a obra não interfere no desenvolvimento do trabalho social, e tão pouco acontece o contrário. $\mathrm{O}$ grupo realizou visita à outras experiências em Aracajú-SE e Ipatinga-MG.

\section{Relação com CEF}

Segundo relatos de técnicos da Secretaria, o processo de cadastramento e analise social das famílias feito pela CEF, foi um processo muito burocrático e moroso. Existem alguns conflitos enfrentados entre Associação e CEF. Seja em relação a interferência nas decisões do grupo, como em relação às medições prejudicando a bom andamento da obra. Segundo o Eng. Bosco para "Cada etapa eu faço o planejamento como se fosse uma nova obra, cada etapa teoricamente deveria ser um mês, mas não está acontecendo isso. Por causa da própria CEF, você faz a obra, e depois de aprovado (a medição), ela demora 15, 20 dias para liberar o recurso." Segundo Ana, outra dificuldade tem sido lidar com a postura de técnicos da CEF que desconhecem o processo e tem atrapalhado o andamento das atividades: "por falta de informação do Crédito e do processo da obra passaram muita informação errada para os titulares. E pra gente desfazer isso tá sendo muito difícil... Porque a CEF é a autoridade, a 'CEF que disse, que financiou, eu já assinei...' Agora é uma desconstrução que teremos que fazer com essas pessoas. " . O grupo tem enfrentado dilemas em relação às regras do programa e que tem dificultado a gestão do trabalho em mutirão.

\section{Particularidades}

Defesa do Programa feita pela gestora pública, que considerando os limites presentes na gestão burocraticia municipal, acreditou que por meio do apoio financeiro e institucional ao movimento organizado, e inspirado na experiência do Funaps comunitário (em entrevista a afirmação de que o centro comunitário projetado para o Vila Solidária mar Azul, foi inspirado no centro comunitário do São Francisco do conjunto do FUNACOM em São Paulo), seria possível promover habitação de qualidade.

* extraído do site: http://ba.unmp.org.br

** Entrevista com eng. Bosco durante o trabalho de campo (24.agosto.2008).

*** Entrevista com Ana (membro da comissão gestora) durante trabalho de campo (24.agosto.2008). 


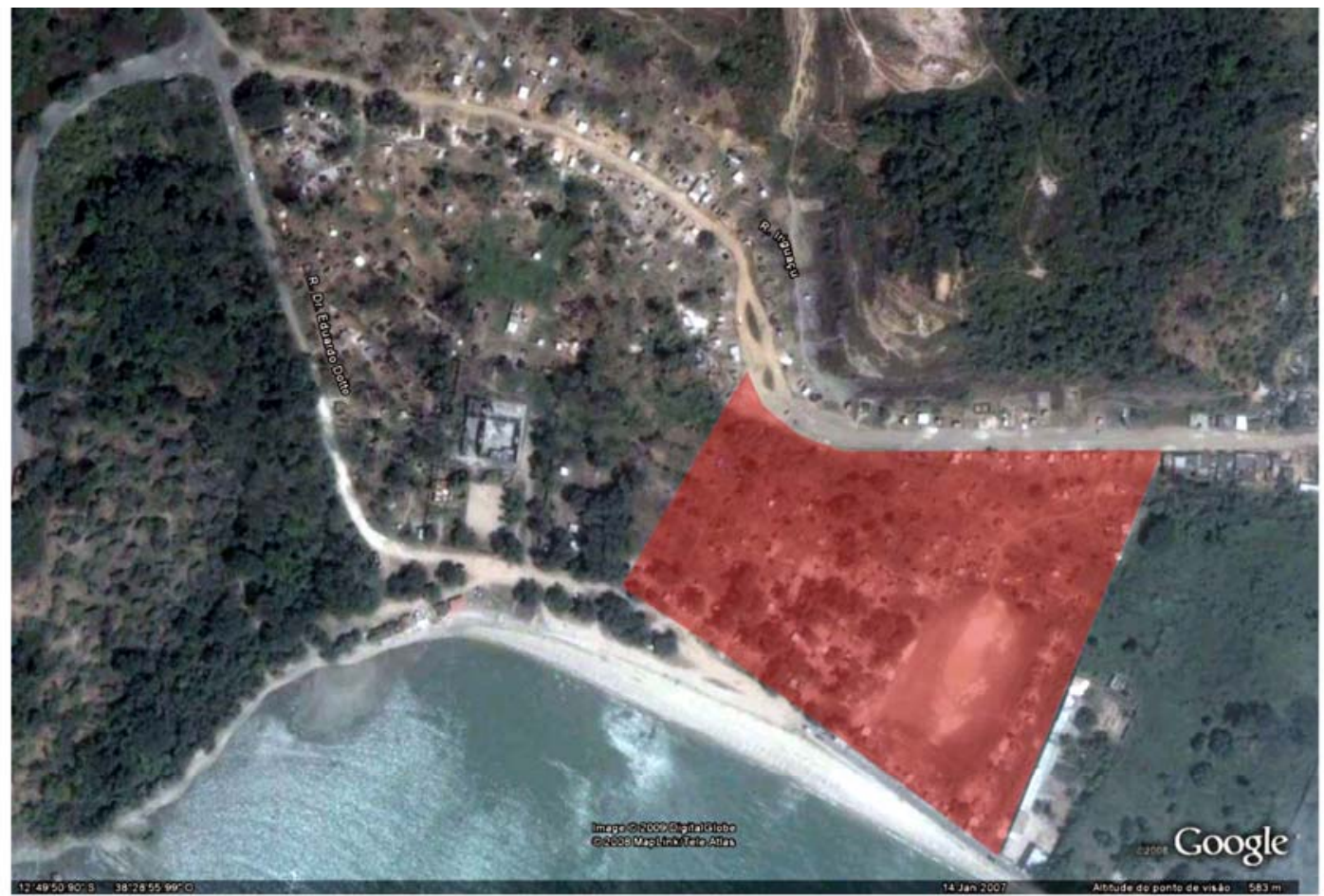

Localização do empreendimento na malha urbana

Fonte: Google Maps

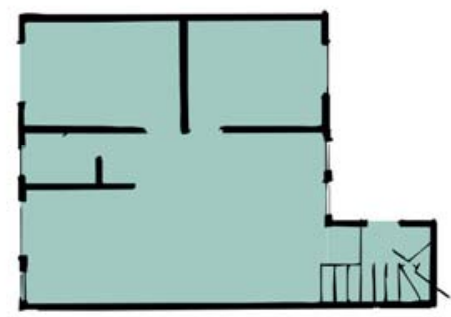



$\mathrm{UH}=32,9 \mathrm{~m}^{2}$
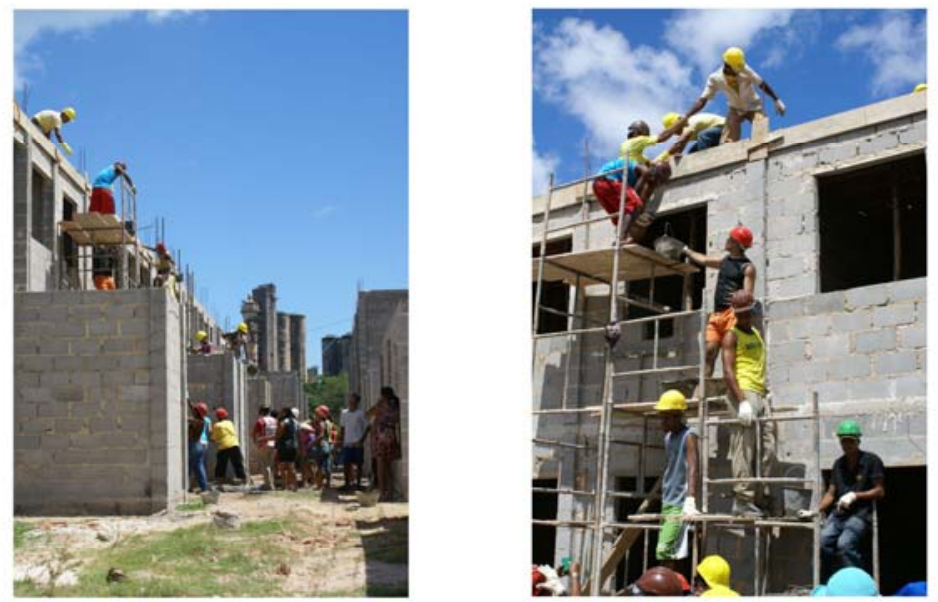

Fotos do canteiro em mutirão Fonte: Acervo próprio

Planta tipo do empreendimento Escala: 1:200

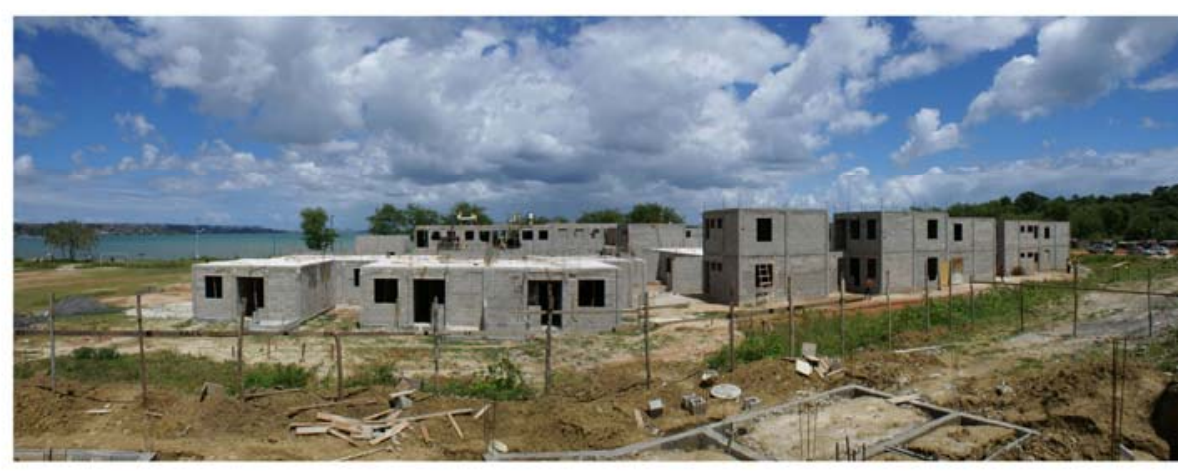

Vista geral do empreendimento

Fonte: Acervo próprio 


\section{Quadro 6}

Trabalho de Campo | Empreendimento Colinas da Oeste | Jaraguá, São Paulo - SP Associação responsável: Associação dos Moradores sem teto da Zona Noroeste

\section{Antecedentes}

A assessoria técnica Ambiente junto à Associação dos Moradores Sem Teto da Zona Noroeste, parte integrante da UMM-SP, trabalham em parceria desde o início dos anos 90 viabilizando por meio da autogestão e financiamento público a produção de habitações populares. Elas iniciaram as negociações com proprietário do terreno de 16 mil $\mathrm{m}^{2}$ demarcado como ZEIS, localizado no Jaraguá, região Noroeste do Município de São Paulo para elaborar a proposta de empreendimentos para o PCS. Em 2006 teve início a formação do grupo, e no começo de 2007 foi solicitada a aprovação dos projetos junto a Prefeitura Municipal de São Paulo. E Somente após mais de um ano de tramitação foram aprovados e com isso a proposta pode ser contratada.

\section{Empreendimento}

O empreendimento Colina da Oeste composto por 200 unidades habitacionais foi contratado em maio de 2008, por meio da nova resolução do PCS, após mais de 2 anos de processo. A efetivação da proposta ocorreu quando as regras do PCS passaram por importantes mudanças, (tratadas no capítulo 4). Entratanto, quando questionamos o técnico da CEF a respeito de qual fator responsável por efetivar a contratação do empreendimento, a resposta indicou o convênio firmado com o governo do estado, complementando os recursos com R\$10 mil por família. No momento da visita ao empreendimento (01.novembro.2008), as obras ainda estavam no começo, com a conclusão da terraplenagem e início da execução das fundações do centro comunitário.

\begin{tabular}{|c|c|c|c|c|c|}
\hline Valores & & VF (FDS)/UH & CP \$/UH & M.O.MUT/UH & COMPL.\$ /UH \\
\hline & \multirow{3}{*}{$\begin{array}{c}\text { Colinas da Oeste (200 } \\
\text { uh) }\end{array}$} & $\mathrm{R} \$ 30.000,00$ & $R \$ 2.138,02$ & $R \$ 2.359,61$ & $\mathrm{R} \$ 10.000,00$ \\
\hline & & VI/UH & VF (FDS) OBRA & V CTA. EQUALIZ. & VI OBRA \\
\hline & & $\mathrm{R} \$ 44.497,63$ & $\mathrm{R} \$ 6.000 .000,00$ & $\mathrm{R} \$ 1.200 .000,00$ & $\mathrm{R} \$ 8.899 .526,00$ \\
\hline Parceria & & & & & \\
\hline
\end{tabular}

O projeto não teve qualquer apoio da Prefeitura. O processo de aprovação do empreendimente demorou mais de um ano para ser concluído, justificado pelo fato de que existirem apenas dois técnicos para analisar todos os processos de novos empreendimentos habitacionais de HIS a serem feitos no municipio de São Paulo, fato que demonstra o descaso dado à questão. O governo do estado, após negociação aberta pelo movimento de moradia, concedeu especificamente para este empreendimento complementação financeira a fundo perdido de $\mathrm{R} \$ 10$ mil por família. Dessa articulação, resultou a criação de um contrato guarda- chuva entre Secretaria de Habitação do estado de São Paulo e a CEF, possibilitando complementação financiera aos atendimentos realizados por meio dos programas federais no estado de São Paulo. Entretanto, cabe somente ao governo do estado a decisão de quais são os empreendimentos que receberão esses recursos, sem que fossem definidos critérios objetivos. Segundo as informações dos mutirantes e assessores técnicos cada família contribui com a contrapartida financeira previamente à assinatura do contrato. Soma-se a isso o valor da mão-de-obra em mutirão estimada em R\$2.359,00 (representa 5\% do VI). O percentual da contrapartida total a ser aportada pela família representa $10,21 \%$ do Valor do Investimento.

Após negociação com o proprietário foi realizada a compra de três dos quatro terrenos que compoe a área total de $16 \mathrm{mil} \mathrm{m}^{2}$. Pelo valor de $\mathrm{R} \$ 55,00 / \mathrm{m}^{2}$ as famílias realizaram o pagamento de $10 \mathrm{mil} \mathrm{m}^{2}$ com parte da contrapartida financeira. O quarto terreno com $6 \mathrm{mil} \mathrm{m}^{2}$ foi adquirido com recursos do PCS. Essa pode ter sido uma estratégia que garantiu a efetivação da compra do terreno, mesmo após quase dois anos da primeira negociação com o proprietário.

O projeto desenvolvido pela Assessoria Técnica Ambiente, custou R\$ 150 mil e foi pago 100\% pela contrapartida das famílias em parcelas a perder de vista. Conta com 200 apartamentos distribuídos em10 prédios de 5 pavimentos com 4 UH cada. A tipologia aprovada pelas famílias possui UH com área útil de $49 \mathrm{~m}^{2}$ com dois quartos, sala, cozinha, wc, área de serviço e terraço (não previsto no orçamento apresentado a CEF, mas muito defendido pelas famílias que aceitaram a condição de complementar os recursos caso não se seja possível construir somente com o dinheiro inicial). Em conversa Marcel (29.outubto.2008), tecnico da GIDUR responsável pelo projeto, afirmou que o projeto do Colinas se diferencia dos demais que está acostumado analisar. Ao ser questionado sobre os aspectos que chamava mais sua atenção, afirmou que o centro comunitário e o paisagismo contribuiam para a qualidade do projeto. 


\section{Garantia \\ Alienação fiduciária \\ Equipamento Comunitário}

Foi previsto o centro comunitário, primeira edificação a ser construída no empreendimento. Teve que ser previsto ainda criação de uma área de reserva ambiental, objeto de Termo de Compensação Ambiental, sem o qual o licenciamento não seria aprovado. A expectativa dos mutirantes é que seja espaço agradável, "como bosque".

Sistema Construtivo
Alvenaria autoportante, com blocos cerâmicos, revestidos.
Acompanhamento da Obra
O acompanhamento também é realizado pela assessoria técnica, que dá apoio técnico e social necessários para o
positivo andamento da obra.

As tarefas são distribuídas entre os mutirantes que estão divididos em três grupos e a cada final de semana dois trabalham e um folga, até a conclusão do centro comunitário, quando a partir de então, no dia "dia de folga" serão realizadas as atividades de formação. Foi previsto no orçamento $5 \%$ de uso de mão de obra mutirante.

\section{Seleção/ perfil das famílias}

A análise cadastral na CEF e aprovação das famílias também foi um longo processo. Muitas famílias foram substituídas após serem reprovadas pela CEF. Assim como os demais casos, o processo também foi aberto à famílias que nunca tinham participado do movimento. Segundo relato do arq. Ricardo, o perfil das famílias aprovadas pelo PCS em São Paulo se diferencia do perfil das famílias que costumavam compor os grupos de mutirantes dos programas anteriores. Trata-se de um grupo na faixa etária de 30 anos, muitos jovens que entraram com renda declarada individualmente de cerca de $R \$ 700,00$, pessoas já formadas, ou que estão fazendo faculdade, e que trabalham de sábado. E destacou que enquanto nos mutirões nos programas anteriores em que trabalhou, cerca da metade dos titulares das famílias estavam desempregados, naquele momento, seja em função da conjuntura econômica como das características do PCS (no contexto de SP) existiam somente cinco.

\section{Trabalho Social}

O trabalho social, sob a responsabilidade de piscologa Simone e desenvolvido em parceria com arquiteto responsável pelo acompanhamento, foi iniciado três meses antes do início da obra, onde foram debatidos temas como a questão habitacional, a autogestão, organização do mutirão. $O$ trabalho técnico social com as famílias, além da definição das comissões exigidas pelo programa, formaram grupos que se responsabilizam por atividades como cuidar da cozinha, do almoxarifado, da limpeza, da segurança e prevenção de acidentes, e por temas mais amplos não diretamente ligados à obra, mas que estimulam o processo de formação e criação de uma identidade ao grupo. Realizaram visita a outros empreendimentos em São Paulo, construídos pelos programas da CDHU e FUNACOM.

\section{Relação com CEF}

Após mais de 2 anos de processo, segundo assessoria, nunca foi tão positivo o relacionamento com os técnicos da Gidur. Destacaram que ao longo desse período, foram conjuntamente buscando conhecer o programa e desatar os impedimentos encontrados para efetivação do contrato. Entretanto há posturas divergentes, críticas às posturas dos técnicos que não se compromentem, para que outras propostas sejam viabilizadas. Em conversa com técnica da CEF, os técnicos se responsabilizam individualmente por cada processo, e caso ocorra algum tipo de irregularidade a CEF (instituição), não dá respaldo algum, nem mesmo viabilizar um advogado para responder a processos juridiciais. Informação que em parte responde a certa posturas de técnicos que não se comprometem com projetos que não estejam interamente de acordo com as normas, e exigências definidas pelas setor jurídico da CEF, por vezes mais "realistas que o rei".

\section{Particularidades}

A legislação de São Paulo para aprovação de projetos é duríssima e apresenta muitas exigências, que acabam interferindo inclusive no custo da obra, como por exemplo a necessidade de hidrante nos andares dos apartamentos, diferente de outros municipios do país, em que a aprovação de projetos de HIS não exige mais do que projeto de arquietura (até porque esses projetos são muito mais simples). Aspecto positivo do PCS ressaltado foi que ao final da obra as famílias terão sua habitação regularizada, diferentemente dos processos realizados tanto com o Programa FUNACOM, quanto com os programas da CDHU. 


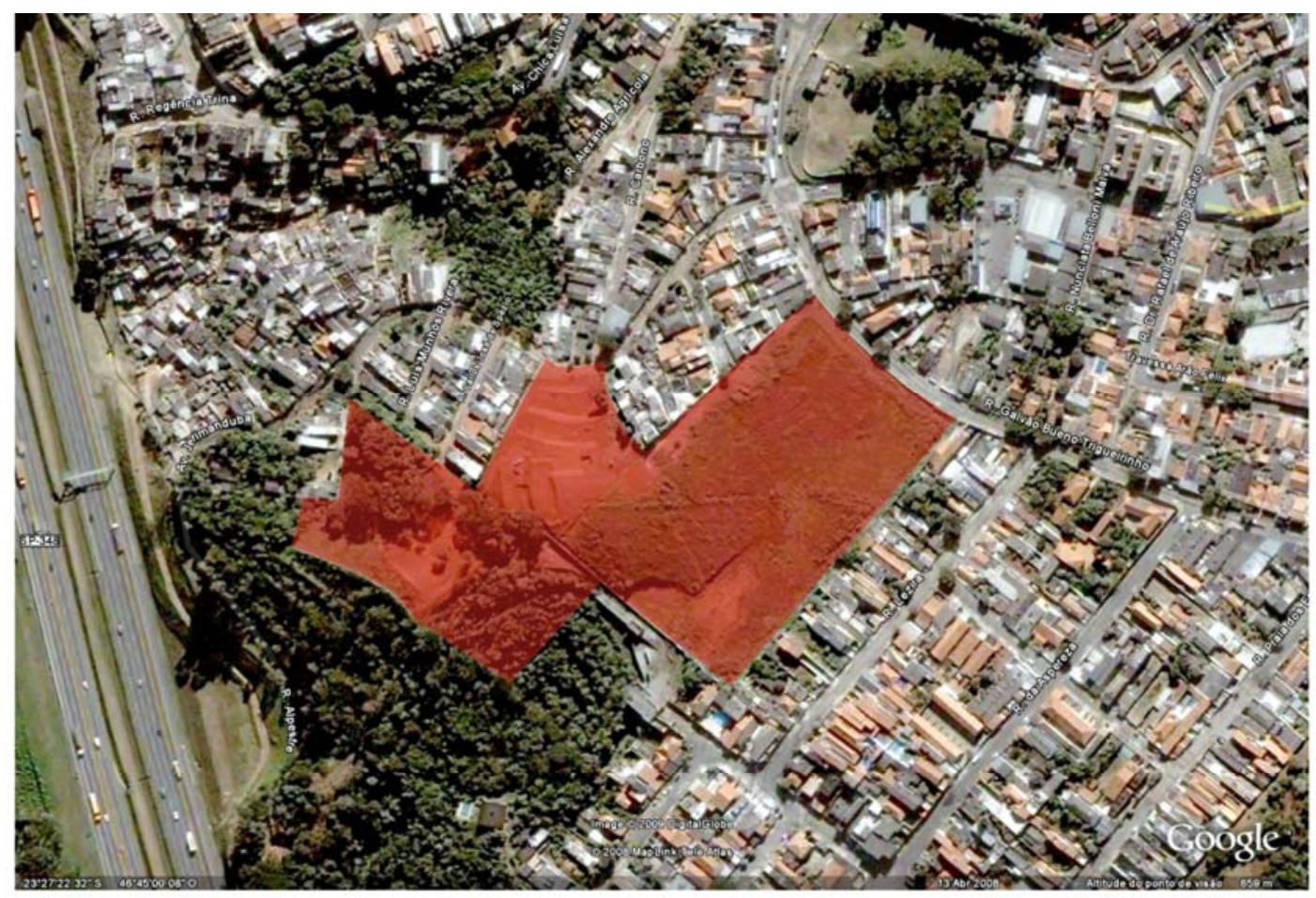

Localização do empreendimento na malha urbana

Fonte: Google Maps

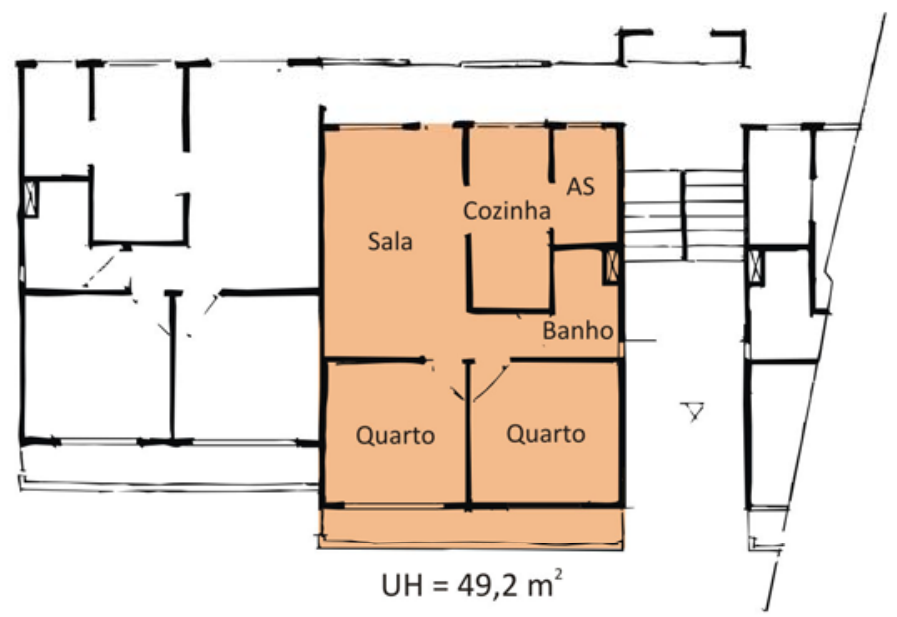

Planta tipo do empreendimento

Escala: 1:200


Fotos do canteiro do empreendimento e simulação em maquete eletrônica Fonte: Acervo próprio 
Um importante mérito que podemos atribuir ao Programa Crédito Solidário, ao responder à demanda apresentada pelos movimentos populares e às orientações definidas pela Política Nacional de Habitação (2004), foi reconhecer as famílias com renda inferior a três salários mínimos como público prioritário. Entretanto, atuar no alvo correto significa enfrentar também uma série de conflitos que se encontram entre a garantia de direitos (à moradia, à cidade, à cidadania) e os interesses de mercado que definem, via de regra, uma disputa desigual, a começar com a questão do acesso à terra urbanizada.

\subsubsection{0 acesso à terra urbanizada}

O preço da terra tem significante incidência no custo final da habitação, especialmente nas regiões mais populosas e urbanizadas, onde a oferta de terra é mais escassa do que as necessidades existentes dentre outros fins o habitacional. O caso de Salvador é ilustrativo e não difere muito da regra geral dos demais aglomerados urbanos brasileiros.

Um estudo desenvolvido por Prof. Gilberto Corso (UFBA), levando em conta relevo, disponibilidade de infra-estrutura e custo considerou em 2002 que menos de $15 \%$ do estoque de áreas livres do território de Salvador, estavam aptos à ocupação habitacional, e apesar desta constatação, na recente revisão do Plano Diretor da Cidade (Lei Municipal no 7.400 de 2008) não foram delimitadas ZEIS de vazios para produção de novas habitações de interesse social.

Enquanto Salvador sofre com a escassez de terras livres e aptas para a produção habitacional, a situação encontrada em Goiânia é ainda mais impressionante, por outras razões. Caracterizado por uma urbanização extremamente espraiada, o município apresenta uma grande quantidade de lotes vagos e revela a forte presença da clássica lógica de especulação fundiária ${ }^{32}$, onde são criados novos loteamentos distantes das áreas consolidadas que recebem investimentos públicos em infra-estrutura e as terras intermediárias são valorizadas. Apesar do Plano Diretor aprovado em 2007 (Lei Complementar no 171) prever instrumentos urbanísticos capazes de conter o mercado de

\footnotetext{
${ }^{32}$ A quantidade de lotes vagos é explicitada no Mapa 6 da Lei Complementar $n^{\circ} 171$ / 2007 - Plano Diretor de Goiânia.
} 
terras especulativo, segundo Vidal ${ }^{33}$, não há prefeito que tenha coragem de aplicá-los e ferir os interesses dos proprietários de terra.

Para se ter uma idéia a incidência do preço da terra no valor total do empreendimento Eldorado Oeste em Goiânia foi de 26\%, enquanto em São Paulo, no caso do Colinas da Oeste significou $10 \%$ do valor total da unidade habitacional ${ }^{34}$, já considerado elevado se considerarmos os limites dos financiamentos habitacionais. Isso porque apesar de apresentar um valor por metro quadrado maior ${ }^{35}$ em relação ao caso de Goiânia, o projeto de São Paulo adotou um partido urbanístico verticalizado, que permitiu otimizar os recursos limitados do financiamento, e ainda atender a um maior número de famílias de maneira adequada.

Por sua vez o empreendimento de Goiânia foi definido por um projeto que não fugiu do padrão urbanístico usual do loteamento baseado no alinhamento e uniformização dos espaços pouco adensados, contribuiu para perpetuar a urbanização espraiada da cidade, além de reduzir os recursos que poderiam ser utilizados para dar melhor qualidade às unidades habitacionais e ao conjunto. Vale ressaltar que a questão não está na mera definição de partido urbanístico adotado por cada um dos empreendimentos, mas na qualidade do projeto e nas possibilidades que este cria para otimizar os recursos e atribuir qualidade à habitação popular.

A exemplo da cidade de São Paulo ${ }^{36}$ e da maioria dos municípios da região metropolitana, os terrenos regulares são caros e quando um terreno que apresenta preço compatível com a disponibilidade do limite do crédito é encontrado, segundo relato do técnico da GIDUR-SP 37 "pode estar certo que é irregular". Assim a obrigatoriedade das

\footnotetext{
${ }^{33}$ Entrevista realizada com Vidal Barbosa, liderança da UEMP-GO, durante o trabalho de campo em 15 de outubro de 2008.

${ }^{34}$ Vale ressaltar que segundo Marcel, técnico da GIDUR-SP, os terrenos nos empreendimentos aprovados na RMSP apresentam valores entre $\mathrm{R} \$ 50,00$ e $\mathrm{R} \$ 200,00$ o $\mathrm{m}^{2}$, ou seja, em São Paulo o empreendimento Colinas da Oeste tem um dos menores valores de terra por $\mathrm{m}^{2}$.

35 O preço da terra no Eldorado Oeste, Goiânia-GO foi de $\mathrm{R} \$ 33,33 / \mathrm{m}^{2}$ enquanto no Colinas da Oeste, São Paulo-SP foi de $\mathrm{R} \$ 55,00 / \mathrm{m}^{2}$. Vale destacar que as informações referentes aos orçamentos dos empreendimentos foram extraídos do Quadros de Composição de Investimento (QCI) de cada empreendimento, e das informações fornecidas pelos entrevistados.

${ }^{36}$ Diferentes autores trataram sobre a problemática da terra em São Paulo, entre eles Cf. ROLNIK, Raquel. $A$ cidade e a lei: legislação e territórios em São Paulo, 1870-1930. São Paulo: Studio Nobel, 1997 e COE, Paulo. São Paulo: "paraíso" dos grileiros. São Paulo: s.n, 1989.

${ }^{37}$ Paulo Henrique, técnico da GIDUR-SP, em conversa realizada no dia 29 de outubro de 2008.
} 
propostas do PCS apresentarem terrenos regularizados por um lado proporcionou o aspecto positivo, já que ao final do processo construtivo o beneficiário terá sua habitação formalizada, por outro tem representado o grande limitante para viabilizar os empreendimentos do Crédito Solidário na capital e demais municípios da RMSP.

Considerando que a produção formal de HIS é em sua maioria viabilizada por financiamentos públicos, e que esses em geral apresentam limites de crédito aquém das necessidades reais, disputar o mercado de terras com o setor privado acaba caracterizandose como um ato de covardia.

“... A gente corre o risco de passar um ano e meio desenvolvendo o projeto e o proprietário resolver vender pra outro mesmo você tendo uma opção de compra e venda bem amarrada. Se for um negócio muito interessante, ele vende e paga a multa pra você, ou assume de se defender num processo." (Ricardo Gaboni, 10.03.2008).

As terras disponíveis vão rapidamente para as mãos daqueles que tem reservas ou crédito fácil (pois apresentam garantias reais) e flexibilidade de negociação, enquanto os financiamentos públicos impõem uma lógica engessada e burocrática, dificultando ainda mais o acesso à escassa disponibilidade de terras para produção oficial de HIS.

Outro fator que deve ser observado diz respeito à localização. A Instrução Normativa no11 do Ministério das Cidades definiu como uma das exigências a inserção dos novos projetos na malha urbana. Entretanto, o que se viu no trabalho de campo foram empreendimentos localizados nas extremidades da manha urbana de seus municípios.

O fato dos empreendimentos de São Paulo e Salvador terem sido obrigados a delimitar uma área de reserva para receber o licenciamento ambiental, em função da presença de mata internamente aos terrenos, denuncia sua localização às margens da malha urbana. No entanto, por pertencerem a regiões metropolitanas muito adensadas, os empreendimentos, mesmo localizados na extrema periferia das capitais têm em seu entorno bairros estruturados e populosos. Diferente da situação encontrada em Goiânia, onde a percepção de que o empreendimento encontra-se descolado da malha urbana consolidada é reforçada pela urbanização espraiada e pela presença de grandes extensões de lotes vagos. 


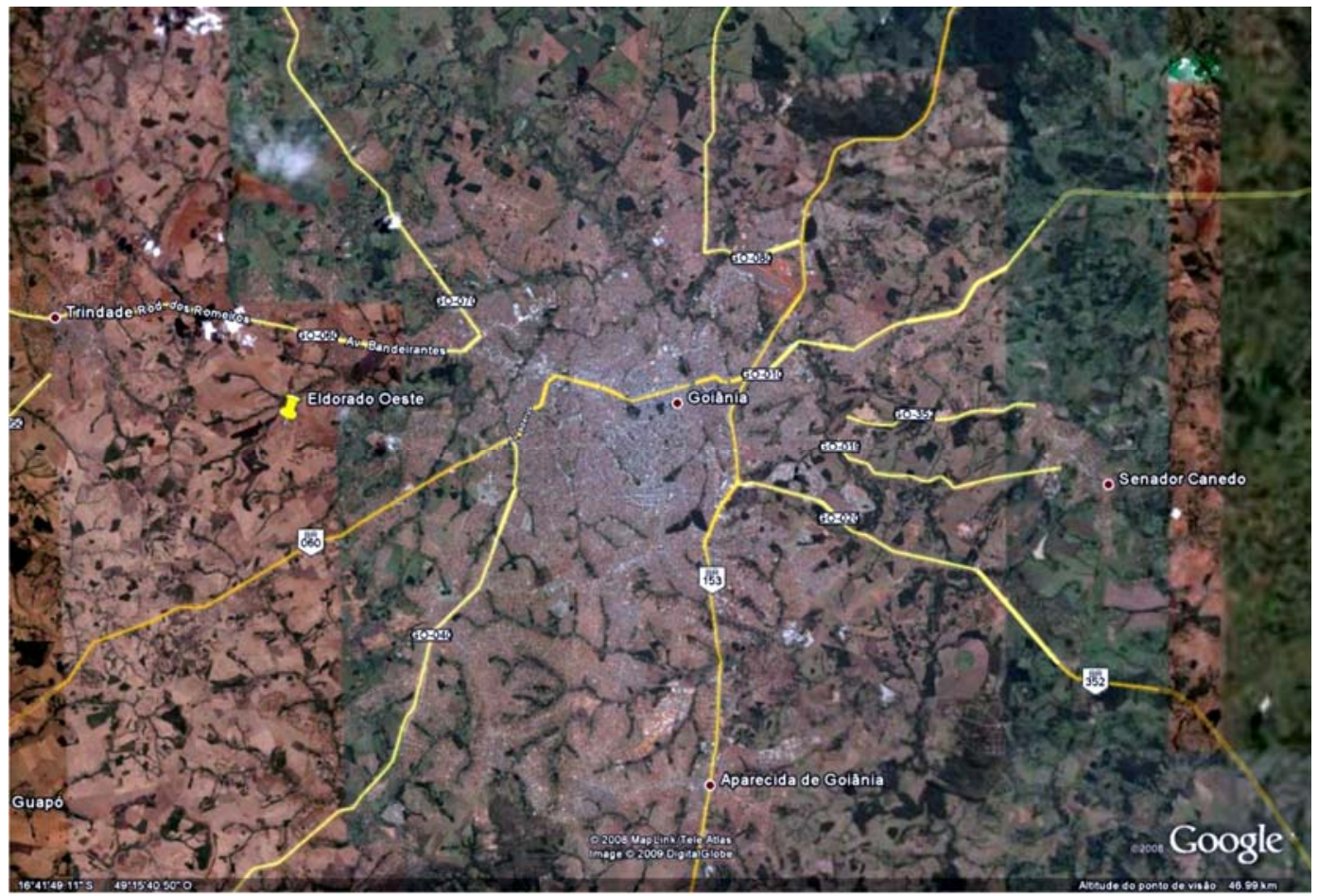

Localização do empreendimento na Região Metropolitana

Fonte: Google Maps

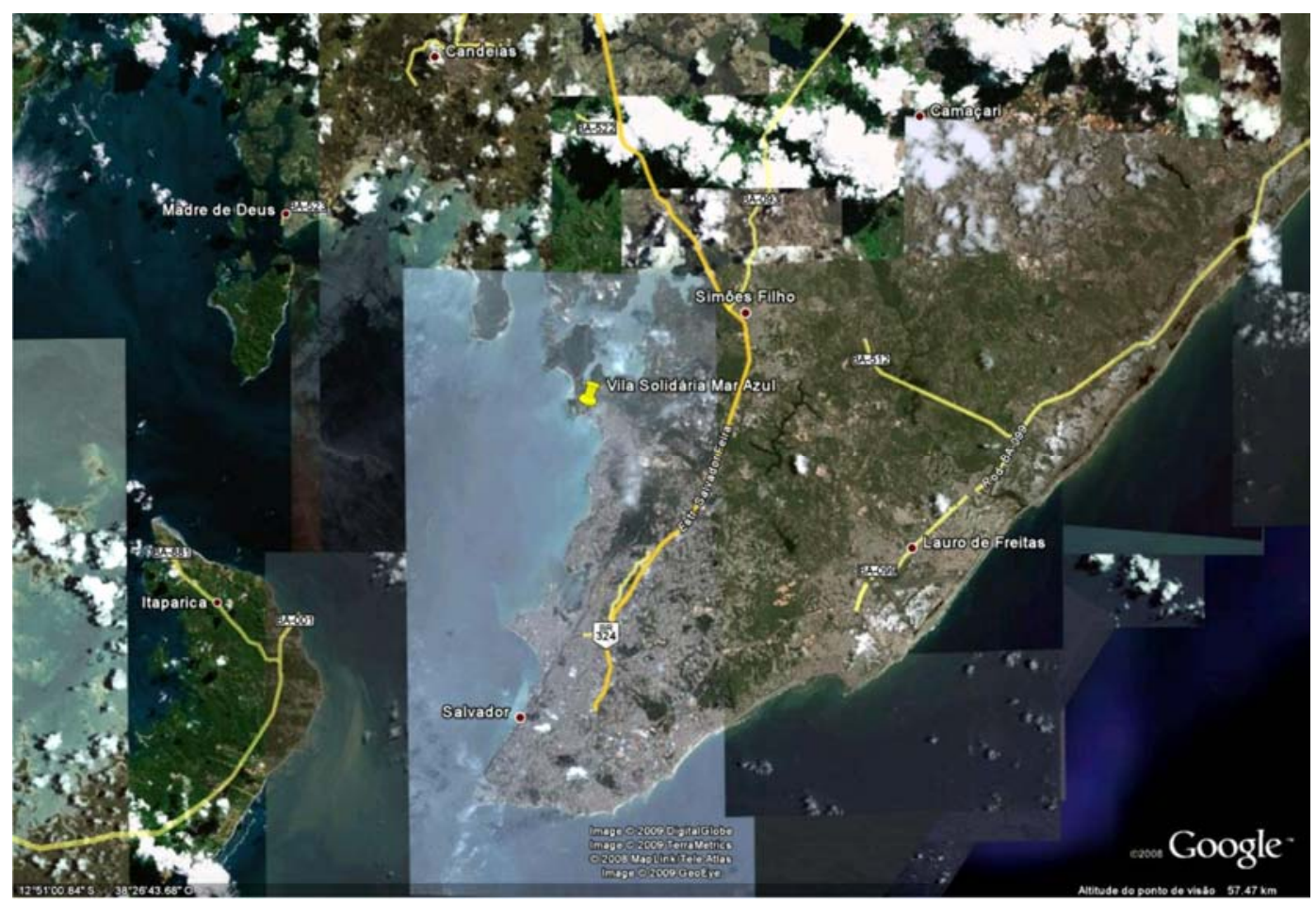

Localização do empreendimento na Região Metropolitana

Fonte: Google Maps 


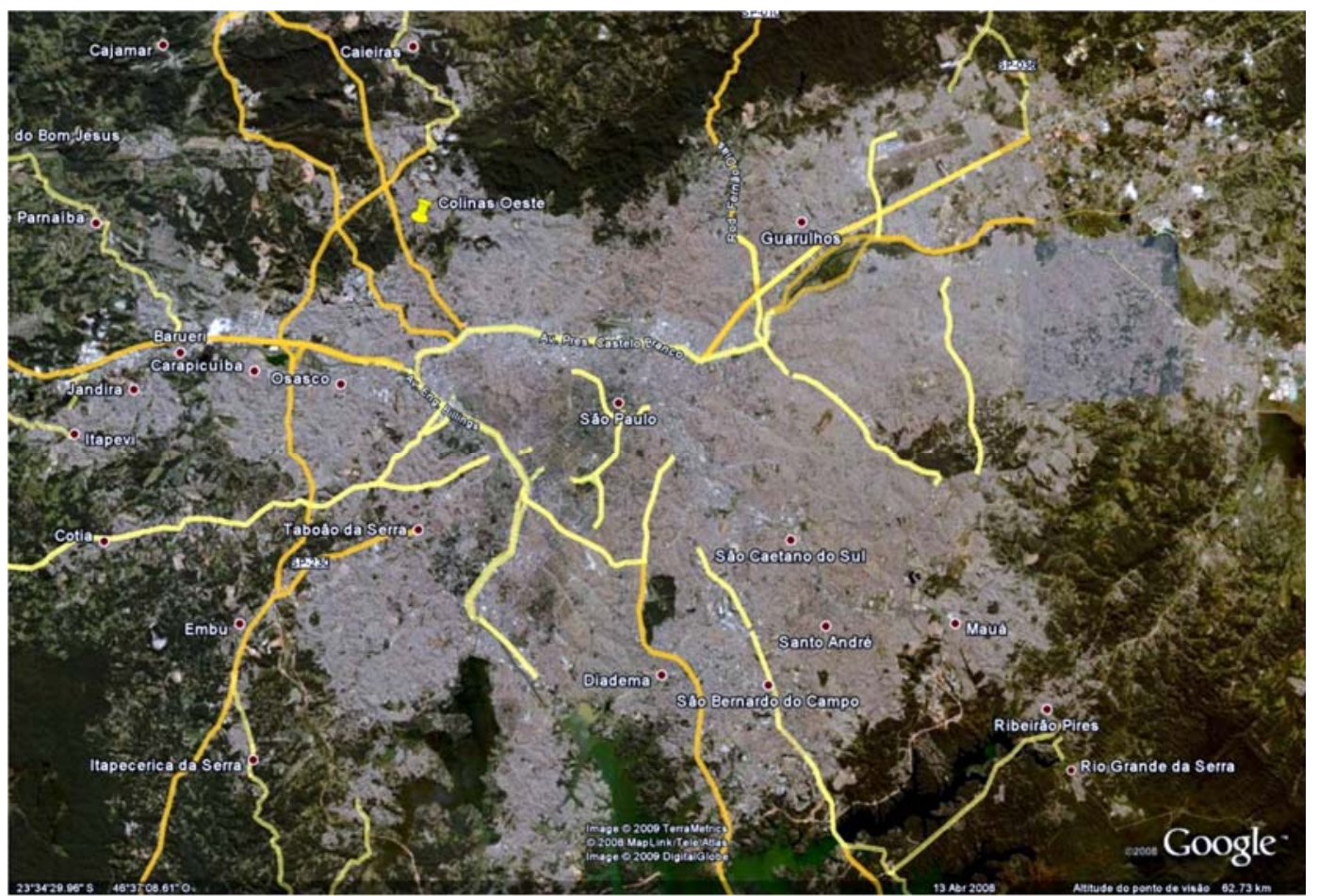

Localização do empreendimento na Região Metropolitana Fonte: Google Maps

Infelizmente, foram verificadas situações como do município de Aparecida de GoiásGO, onde o empreendimento de 200 unidades habitacionais financiado pelo PCS encontra-se completamente isolado da mancha urbana.
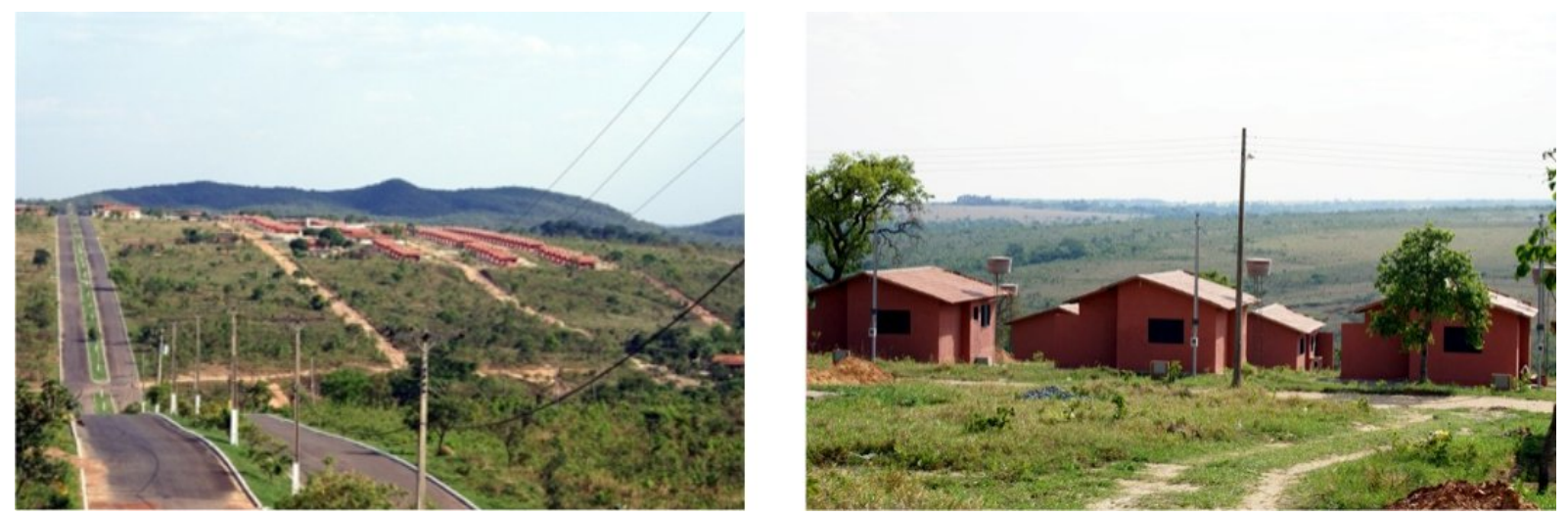

Conjunto do PCS em Aparecida de Goiás (200uh), isolado da malha urbana.

fonte: acervo próprio

Por outro lado, o PCS também tem viabilizado empreendimentos inseridos na malha urbana, especialmente, as propostas de requalificação de edificações em áreas centrais. Como o caso da do edifício na Rua Regente Feijó no centro Rio de Janeiro de propriedade do governo do estado, ocupado há oito anos por nove famílias da Associação Moradia Digna 
nas Áreas Centrais, que passará por reforma com recursos do PCS e sua posse será regularizada por meio da Concessão do Direito Real de Uso (CDRU) à associação ${ }^{38}$.

O mesmo tipo de intervenção vem sendo desenvolvida em parceria com a Secretaria do Patrimônio da União (SPU) ${ }^{39}$ que disponibilizou o acesso à terra da União por meio de CDRU à Associação Cortiços do Centro da cidade de Santos-SP que apresentou proposta ao Crédito Solidário para reforma da edificação de antigo cortiço da área central que irá abrigar 113 famílias $^{40}$. O caso pioneiro foi a negociação feita com Instituto Nacional de Seguridade Social (INSS) para realizar a transferência de posse do edifício localizado no centro de Porto Alegre e ocupado durante o Fórum Social Mundial em 2005, e sob coordenação do MNLM que terá a reforma viabilizada pelo PCS.

\subsubsection{Garantias de risco: "dois pesos e duas medidas".}

Outro passo significativo dentro da política habitacional foi reconhecer as associações e cooperativas como agentes do processo de produção habitacional, por proporcionar a elas, a partir do momento que podem realizar a administração direta da obra, a possibilidade de produzir um novo paradigma de habitação popular. Isso se reconhecermos o pressuposto que as associações representam os interesses de seus associados e que esses não visam extrair lucro dos recursos públicos destinados à produção habitacional, mas sim garantir qualidade à construção de suas futuras moradias.

Podemos afirmar, no entanto, que esse reconhecimento não foi completo dado que a CEF elaborou um desenho operacional não ajustado às condições do tomador do recurso. Este tem sido o principal problema para efetivação do programa, e que gera outros tantos. Como apresentado no capítulo anterior, a operacionalização do Crédito Solidário foi feita com base no desenho tradicional das operações de financiamento usualmente realizadas

\footnotetext{
${ }^{38}$ Informações extraídas do site: http://www.cidades.gov.br/noticias/projeto-de-credito-solidario-e-premiadopelo-iab-rj. Acesso realizado em 12 de janeiro de 2009.

${ }^{39}$ A Lei Federal no11.481 de 2007 criou mecanismos para facilitar e otimizar a regularização fundiária e provisão de HIS em imóveis da União, INSS e extinta RFFSA, ao adequar a legislação de Patrimônio da União e aquelas que se relacionam com o tema, com o propósito de desburocratizar os processos de emissão de títulos de CDRU para famílias de baixa renda e criação de instrumentos de alienação e transferência de imóveis vazios para esses projetos.

${ }^{40}$ Informações extraídas do site http://www.cidades.gov.br/noticias/credito-solidario-financia-moradia-paramoradores-de-corticos-de-santos-a-juro-zero. Acesso realizado em 12 de janeiro de 2009.
} 
com o poder público ou com construtoras que possuem, ao menos, uma estrutura mínima e recursos próprios para realizar o investimento prévio à contratação do financiamento.

No caso do PCS, uma associação que não tem terreno próprio, após negociar e firmar a opção de compra e venda de uma propriedade que pode durar seis meses ou um ano, conforme a negociação, inicia um longo processo que demanda obstinação.

Para o desenvolvimento dos projetos, orçamentos e cronogramas, a associação deve contratar profissionais para desenvolvê-los, e antes disso deve contratar os serviços de levantamentos planialtimétrico e sondagem. Com o correr do prazo da opção de compra e venda, as chances de elaboração do projeto junto com as futuras famílias (um dos elementos fundamentais dentro de um processo autogestionário) são muito pequenas, dado que estas ainda estão sendo cadastradas e orientadas a apresentar as cópias dos documentos civis e comprovantes de renda sujeitos à análise da CEF.

Com a conclusão dos projetos solicita-se a aprovação junto à prefeitura e órgãos licenciadores, e paga-se as taxas. Dá-se entrada do processo na CEF, que inicia a análise jurídica da documentação da propriedade e da associação, e paga-se novas taxas. Coletados todos os documentos e concluído o cadastro das famílias com cerca de $50 \%$ a $100 \%$ a mais do que o número de unidades propostas ${ }^{41}$, a CEF então pode iniciar a análise cadastral, e paga-se outras taxas. Como se viu, os prazos de elaboração e aprovação do projeto não se articulam com longo processo para se conseguir fechar o grupo de titulares e o prazo para que a CEF realize a análise do grupo. E soma-se a isso, a dificuldade em mantê-lo coeso até o fim da epopéia.

Somente depois da aprovação de todas essas etapas, a proposta pode então ser contratada. Essa corrida de obstáculos, e contra o tempo, que antecede a contratação significa um investimento de alto risco para associação, pois não há garantias de que o financiamento seja de fato efetivado. Não foram poucos os relatos sobre propostas inviabilizadas e investimentos perdidos, quando após percorrer todo o processo ${ }^{42}$, as associações tiveram o prazo da opção de compra e venda vencido. E o proprietário irredutível, não aceitou negociar novamente.

\footnotetext{
${ }^{41}$ Isso porque, grande parte desta demanda tem sido reprovada por apresentar irregularidades nos cadastros de crédito, na documentação do estado civil, ou por falta de capacidade de endividamento.

${ }^{42}$ Para se ter uma idéia, a duração dessa primeira etapa nas três situações visitadas foi em média dois anos.
} 
Mesmo se considerarmos que na concepção do programa, o pagamento desses serviços foi pensado a ser feito pela contrapartida mínima exigida das famílias, o risco sobre o elo mais fraco persiste caso a proposta não seja contratada. E ainda, os riscos financeiros dessa etapa inicial podem ser tanto da associação e famílias que se cotizam para pagar os serviços sem a garantia de efetivação do contrato, quanto dos profissionais que podem aguardar pelo pagamento dessas atividades após a assinatura do contratado (o trabalho social com as famílias, por exemplo, é exigido pelo Programa que seja feito três meses antes da assinatura do contrato).

As garantias à CEF (agente operador), por sua vez, foram consideradas a priori quando o desenho da operação definiu que os subsídios (que torna mais barato o financiamento e possibilita o acesso ao crédito às famílias que não apresentam garantias reais) fossem destinados ao pagamento dos custos da operação independentemente do desempenho do Programa, conforme exposto no capítulo anterior ${ }^{43}$. Já o risco do agente financeiro é assegurado no momento da assinatura dos contratos, pela aplicação da alienação fiduciária. Para que se execute esse tipo de garantia, é necessário que as matrículas estejam individualizadas, tornando obrigatório o parcelamento ou a incorporação do imóvel antes da execução da obra, mesmo que originalmente o imóvel esteja em nome da associação. Trata-se da condição que justifica a obrigatoriedade a todas as propostas do PCS apresentarem terrenos regularizados

Se a individualização do crédito e assinatura dos contratos antes da obra tem assegurado as garantias à CEF, conforme ilustrados pelas experiências de Salvador e Goiânia, têm proporcionado limites à gestão da obra e dificuldades para envolver as famílias nas atividades coletivas, a começar pelo mutirão.

Quando os beneficiários possuem o direito prévio sobre moradia, adquirido ao assinarem os contratos com a CEF com a pré-definição das casas, torna-se muito mais difícil viabilizar a autogestão da obra e o envolvimento de cada um no trabalho do mutirão. Buscando contornar esse tipo de problema, com o andamento do programa, algumas associações abriram brechas, como a negociação feita entre UEMP-GO e CEF local. Primeiro todos os contratos assinados ficaram sob responsabilidade da associação, para que as

\footnotetext{
${ }^{43}$ No caso do programa Operações Coletivas da Resolução 460 do CCFGTS, onde os financiamentos são caucionados, os subsídios são destinados para abater o valor do imóvel.
} 
famílias não soubessem seus lotes, e pudessem contribuir com sua força de trabalho e com a mesma qualidade no empreendimento todo. E a CEF permitiu também que a associação, por meio de uma procuração das famílias, pudesse solicitar a substituição de titulares que descumprissem o regulamento de obras. A Associação mesmo com a autorização das famílias, não deixou de submeter cada decisão à aprovação da assembléia geral ${ }^{44}$.

As regras rígidas relacionadas aos compromissos do mutirante ${ }^{45}$ e às penalidades nos casos de infração ${ }^{46}$ são debatidas coletivamente e passam a fazer parte do regulamento de obras aprovado em assembléia. Retomando a idéia de Guillerm e Bourdet, apresentadas na introdução dessa dissertação, com base nos princípios da igualdade e liberdade próprios da autogestão, "... todos os membros do corpo social (...) criam contratualmente uma lei geral (e isso será a autonomia) que os organiza sem gerar entre eles diferenças de poder..." (1976:53).

No caso de Salvador, a CEF local ${ }^{47}$ vinha interferido na autonomia do grupo ao passar orientações contrárias ao regulamento, provocando desde conflitos internos até esvaziamento da participação no mutirão, conforme relatados por Ana (2008) ${ }^{48}$.

O limite à autonomia ao grupo para tocar e definir as regras do processo está relacionado também a ordem de escolha das unidades habitacionais. A definição da escolha das casas tem sido feita pela CEF por sorteio na montagem dos contratos individualizados, ignorando os pactos sociais estabelecidos pelos membros da associação e o critério de

\footnotetext{
${ }^{44}$ Em agosto de 2008 no momento da visita de campo ao empreendimento no Paripe (Salvador), a associação não estava sabendo como responder às ausências dos mutirantes na obra e nas atividades coletivas. Posteriormente, identificamos no site da UMP-BA, atualizado em novembro de 2008, a notícia que relatava o caso de nove famílias que haviam sido expulsas do processo por não terem participado das atividades coletivas após assinatura do contrato. Demonstrando que essa flexibilidade também foi assumida pela CEF da Bahia. Em http://ba.unmp.org.br/index.php?option=com_content\&task=view\&id=115\&Itemid=36; acesso realizado em 12 de janeiro de 2009.

${ }^{45}$ Os compromissos dos mutirantes vão, por exemplo, desde a participação no trabalho, participação das atividades mensais de formação, o uso adequado das ferramentas e equipamentos de proteção, até à proibição de uso de bebidas alcoólicas, drogas e porte de arma.

${ }^{46}$ São definidos critérios para cada infração cometida que vão desde advertências por escrito à expulsão e substituição da família no processo.

${ }^{47}$ Segundo ponderação de Luciana Royer, técnica da GIDUR-SP em entrevista realizada em 25 de janeiro de 2008, em muitos casos os técnicos da CEF veem a associação como um perigo ao beneficiário final e trabalha na lógica de sua proteção.

${ }^{48}$ Membro da Comissão de Acompanhamento de Obras do empreendimento Vila Solidária Mar Azul, SalvadorBA, em conversa realizada durante trabalho de campo, em agostos de 2008.
} 
mérito de cada família ao final do processo construtivo, definido por uma pontuação que considera ao longo da obra "pontualidade, assiduidade, responsabilidade, respeito ao trabalho e às pessoas, adimplência nas contribuições e comprometimento com esse regulamento" $^{49}$. O critério do mérito originalmente presente nos processos de autogestão desempenha na prática autogerida o papel de atribuir a cada um, sua importância e responsabilidade perante o grupo, e concretamente, estimula a participação no trabalho.

Soma-se a esses aspectos o fato de que a Instrução Normativa no 11 onde foram publicadas as orientações do programa elaboradas pelo Ministério das Cidades, sugere à associação a utilização de alguns mecanismos com o propósito de reduzir os custos de obras e serviços. Entre eles estão a (a) "elaboração de cadastro de projetos, especificações $e$ orçamentos a serem fornecidos aos beneficiários finais", (b) "levantamento dos custos de materiais de construção, indicando aos beneficiários finais as possibilidades de obtenção de menor preço", (c) "formação de banco de materiais de construção, propiciando aos beneficiários finais a compra de materiais por preços inferiores aos praticados no mercado", e outros que claramente referem-se à autoconstrução da habitação. Em nenhuma parte do texto foi utilizado o termo autogestão, como uma forma de otimização do processo produtivo, nem mesmo se considerou o estímulo à ação coletiva como forma de potencializar a produção.

Foi possível perceber que as condições do programa (quer definidas pela CEF, quer definidas pelo Ministério das Cidades) induzem a todo o momento a ruptura com a lógica coletiva, própria da autogestão.

\subsubsection{Qual o devido papel à associação?}

Podemos a afirmar que se perpetua ainda hoje, o impasse nascido nos anos 90 , no qual a sociedade civil ganha novo significado, muito mais complexo, decorrente das transformações do Estado Brasileiro daquele momento ${ }^{50}$. O incentivo ao associativismo

\footnotetext{
${ }^{49}$ O Regulamento de Obras do empreendimento Colinas da Oeste, São Paulo-SP, foi construído pelo grupo, aprovado em assembléia e registrado no cartório no em novembro de 2008.

50 Com base em MARTINS (2007) a Reforma Gerencial do Estado foi promovida a partir de 1995 com a elaboração do Plano Diretor da Reforma Gerencial do Estado e em novo contexto econômico mundial da globalização. Os principais elementos da proposta estavam na transformação do papel do Estado e estratégias de desenvolvimento, revisão das funções vitais da burocracia pública e a possibilidade de trabalhar com
} 
acarretou na convivência de dois grupos críticos ao modelo de Estado marcado pelo fisiologismo, clientelismo, paternalismo e centralismo, apesar de essencialmente divergentes em relação a entendimentos e propostas relacionadas às práticas políticas, garantias de diretos e papel do Estado (DAGNINO, 1999).

De um lado o grupo que se caracteriza pelo direito de reivindicar direitos e pelo direito de adotar novos padrões de comportamento nascidos nos anos 70, que persiste em buscar a universalização dos direitos políticos, sociais e civis, que se baseia em critérios da igualdade e justiça social e que atribui ao Estado à responsabilidade de apresentar soluções construídas participativamente, bem como de regular as ações do mercado.

Do outro lado o grupo com entendimentos e projetos políticos alinhados às reformas do Estado induzidas pelos princípios neoliberais que transformaram cidadãos portadores de direitos em duas categorias de sujeitos: de um lado os clientes que podem pagar pelos serviços promovidos pelo mercado, e de outro os receptores de generosidade e favores ${ }^{51}$. A velha filantropia, ganha nova aparência social e novas relações associativas passam a tomar para si o que seria a responsabilidade do Estado, como espécie de responsabilidade moral de praticar "solidariedade aos mais pobres" excluídos do mercado.

Ao analisar a prática do Crédito Solidário, e ponderar sobre o papel atribuído à associação pelo desenho do Programa desenvolvido pela CEF, podemos arriscar algumas considerações. A afirmação de Oliveira (2003) de que a onda neoliberal desmontou os mecanismos que garantiam aos movimentos populares a possibilidade de atuação política, nos induz a percepção de que a distinção entre os grupos apresentados acima possa ter se tornado mais tênue, ou que esteja a todo o momento sendo posta em questão.

Na prática, a obra inicia quando a CEF adianta a primeira parcela do cronograma financeiro para execução das atividades estabelecidas para o primeiro mês. Entretanto muitas associações viram parte desse primeiro desembolso ser descontado pela cobrança da correção monetária e dos seguros no período de obra, não prevista nos cronogramas físicofinanceiros propostos pelas associações e aprovados pela CEF. Se as associações não tinham

modelos institucionais diferenciados. O princípio norteador da Reforma estava na gestão pública desestatizante dividida em seis eixos, entre eles o da gestão social, a partir do qual foram estimulados entre outros o fortalecimento do associativismo.

${ }^{51}$ OLIVEIRA, Francisco. Os direitos do antivalor: a economia política da hegemonia imperfeita. Coleção zero a esquerda. Petrópolis : Editora Vozes, 1998 apud Carvalho (2004). 
a informação sobre essa condição, faltou a CEF orientá-las para corrigir os orçamentos antes da aprovação do recurso.

Soma-se a isso o fato da medição da obra executada acontecer, somente quando $100 \%$ do cronograma previsto no mês estivesse concluído. Nos programas anteriores dos municípios de Belo Horizonte e São Paulo, era possível fazer uma medição parcial, por exemplo, de $90 \%$, receber por ela, realizar os pagamentos fixos mensais devidos e cumprir com os $10 \%$ restantes no mês seguinte, sem prejudicar o andamento da obra e permitir certa flexibilidade pertinente aos processos autogeridos.

"As condições do Crédito Solidário te induzem a fazer modelo de empreiteirazinha,(...) no sentido das decisões não serem compartilhadas. (...) Se for esperar a reunião para todo mundo decidir vai passar o prazo da medição..." (Evaniza Rodrigues, 27.02.2008)

Buscamos ser cuidadosos ao longo da análise para não incorrermos na tendência, já antecipada no início deste capítulo, de tomarmos como referência a visão parcial do processo baseada na experiência paulista. Mas trazer determinados aspectos nos auxilia na construção dessa análise.

A dicotomia entre o tempo da execução da obra e o cumprimento do cronograma físico financeiro, e do trabalho desenvolvido coletivamente e o processo de formação das pessoas, foi apresentada em Silva (1994:43) em debate sobre a experiência do FUNAPSComunitário, justamente pela preocupação que se tinha em promover por meio da autogestão a transformação da cultura política das pessoas envolvidas no processo de produção da casa.

"Sobra muito pouco tempo para aprofundar as questões de educação popular (...) Acho que o desafio em relação à cultura está na distância que existe entre o fazer e a reflexão sobre aquilo que está sendo feito."(LOPES, apud SILVA, 1994:43).

Essa dicotomia aparece nesse novo contexto como uma questão superada, já que si quer foi previsto qualquer espaço (e tempo) para que fosse fomentado o processo de formação no sentido descrito acima. Como sugere o documento Orientações Técnicas, Programa Crédito Solidário elaborado pela CEF, onde foram apresentadas as orientações para o desenvolvimento do trabalho social: 
"O Trabalho Técnico Social no Programa Crédito Solidário visa contribuir para a sua sustentabilidade. 2.1.2 A sustentabilidade do Programa está pautada nos aspectos econômico e social. 2.1.2.1 No aspecto econômico ressalta-se a importância da manutenção da adimplência, principalmente no que se refere às taxas de amortização do financiamento. 2.1.2.2 0 aspecto social consiste no desenvolvimento de atividades participativas que propiciem convivência harmoniosa entre as famílias e a existência de atitudes positivas quanto à conservação da unidade residencial $e$ áreas de uso comum. 2.1.2.3 Portanto, a sustentabilidade implica na correta compreensão de direitos e deveres, no estabelecimento de regras de convivência e atitudes positivas quanto ao pagamento das obrigações financeiras assumidas, como forma efetiva de acesso à moradia." (CEF, 2006:2-3).

Como se vê, o desenho operacional e as orientações apresentadas pelo banco, o PCS atribuiu à Comissão de Acompanhamento de Obra o papel de ser simplesmente "tocador de obras", e à associação o papel de solidarizar-se com os mais pobres, e tomar para si a responsabilidade usualmente atribuída ao Estado: organizar a demanda, desenvolver projetos técnicos, dar apoio social às famílias, administrar os recursos aplicados à obra, e assim por diante.

\subsubsection{0 valor financiado: limites para a proposta}

O baixo limite do valor financiado por unidade habitacional, não é uma questão exclusiva ao PCS. Entre as administrações públicas é regra geral a avaliação, inquestionável, de que para enfrentar o déficit habitacional deve-se atuar na escala do problema. A questão está na tomada de decisão que determina que para priorizar a quantidade em face dos recursos disponíveis, necessariamente deve-se desconsiderar a qualidade. O poder público para otimizar os recursos e "... pra diminuir custo, diminui a unidade, piora o projeto, como se (apenas) isso fosse representativo no custo final. (...)"( Ricardo Gaboni, 10.03.2008).

Os limites de crédito estabelecidos pelo PCS desconsideraram certas peculiaridades pertinentes à proposta de autogestão, e condicionaram às associações a inevitável necessidade de firmar parceria com o poder público local ou estadual, seja com aporte de recurso, apoio técnico, meios de agilizar aprovação de projeto, ou mesmo com terreno. Apenas com os recursos do PCS e a contrapartida mínima exigida das famílias tem-se 
mostrado inviável produzir HIS por meio da autogestão, especialmente nas regiões metropolitanas.

A experiência de São Paulo é emblemática dessa condição. Somente após a complementação financeira a fundo perdido em $\mathrm{R} \$ 10$ mil do governo do estado (que representou cerca de $20 \%$ do valor de investimento), foi possível contratar o a proposta Colinas da Oeste, conforme descrito no quadro do empreendimento. As famílias também tiveram que aportar uma contrapartida financeira significativa que somadas à mão-de-obra mutirante representaram juntas $10,2 \%$ do Valor de Investimento (VI). Situação similar ocorreu no empreendimento de Salvador que contou com mais de $25 \%$ do VI decorrente da parceria viabilizada tanto pelo governo do estado, quanto da prefeitura ${ }^{52}$. Neste último caso, entretanto, as famílias entraram apenas com a contrapartida da mão-de-obra mutirante estimada em $6 \%$ do Valor de Investimento. Já o empreendimento Eldorado Oeste em Goiânia, que conseguiu ser viabilizado sem firmar parcerias com o poder local, mostrou que sem esse apoio, a participação das famílias foi proporcionalmente maior. Lá o percentual em contrapartida por família (financeira e mão-de-obra mutirante) representou $17 \%$ do Valor de Investimento ${ }^{53}$.

Outros limites impostos pelo baixo valor do financiamento também interferem na execução da obra quanto à organização do canteiro, à possibilidade de contratação de empreitada para minimizar o trabalho em mutirão, entre outros aspectos. $E$, considerando o desenvolvimento de um processo que se pretende coletivo,

“... o maior problema é você não ter recurso dentro desse financiamento que vai permitir projetar um equipamento de uso coletivo que vai permitir a organização dessa população que está lá. (...) Se a gente quer que haja formação, organização, administração do próprio condomínio, qualquer ação que envolva um processo coletivo, você precisa de um espaço para isso." (Ricardo Gaboni, 10.03.2008).

\footnotetext{
52 Vale lembrar que o único valor compatibilizado decorrente da parceria da prefeitura foi o da desapropriação do terreno em $\mathrm{R} \$ 213.008,53$, todos demais apoios técnicos e institucionais, bem como a elaboração e execução do centro comunitário não foram considerados. Portanto, certamente o percentual do investimento decorrente da parceria realizada com a Prefeitura é significativamente maior.

${ }^{53}$ É importante destacar que as informações referentes ao valor da mão-de-obra mutirante apresentados aqui foram extraídas dos QCls dos empreendimentos, e não se sabe como foram calculados cada um desses valores, podendo ocorrer assim uma possível distorção entre os valores reais de cada um deles.
} 
A existência de um equipamento nesses moldes bem como a aparência deste, que podemos nomear de centro comunitário, demonstra a importância dada ao processo coletivo em cada um dos empreendimentos. Pois é nesse espaço múltiplo, e potencialmente político, onde se desenvolvem as atividades coletivas extra-canteiro de obras, os processos de discussão (assembléias), formação e integração do grupo. Sem ele, essas ações não podem existir $^{54}$, e com ele, mas de forma precária, essas ações podem existir, mas sua potência será minimizada.
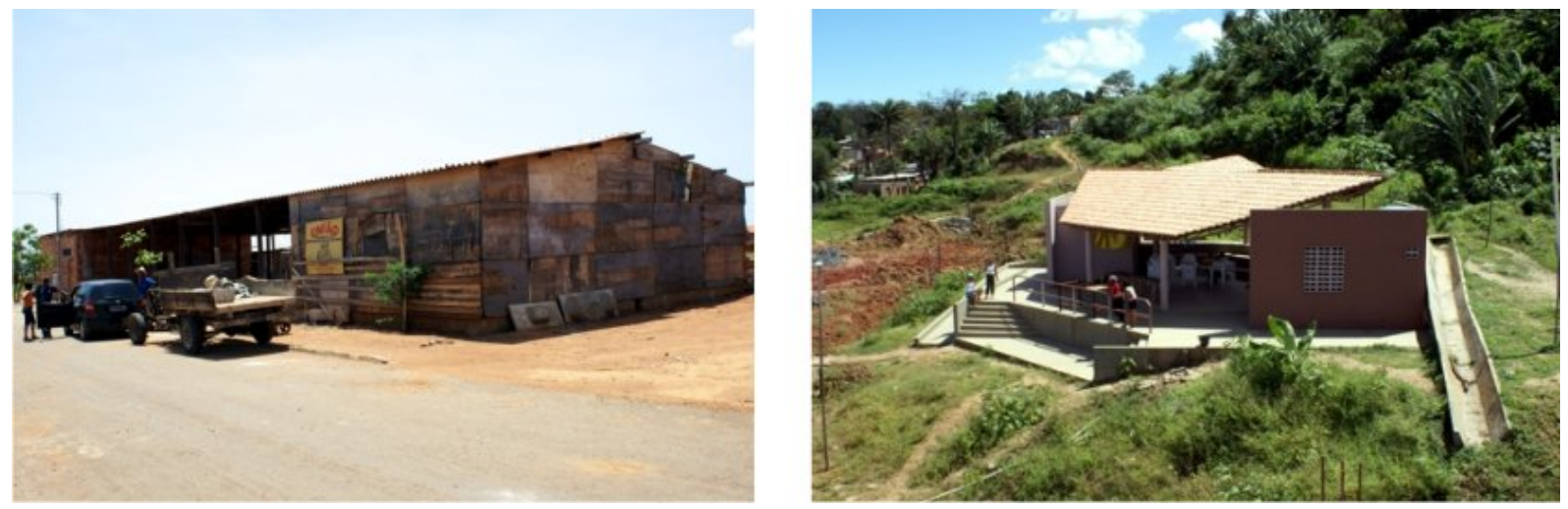

Centros Comunitários dos conjuntos Eldorado Oeste (Goiânia) e Paripe (Salvador).

fonte: acervo próprio

\subsubsection{Assessoria Técnica: garantia da autogestão e da qualidade das habitações?}

Considerando que a maneira como se pensa o espaço define a potencialidade de influir em um determinado processo social ${ }^{55}$, a assessoria técnica ${ }^{56}$ nos moldes que foi proposta pelas experiências uruguaia e paulista é um instrumento de fundamental importância aos empreendimentos habitacionais autogeridos ${ }^{57}$. Isso porque esses agentes entendem, a priori, seus interlocutores como cidadãos.

\footnotetext{
${ }^{54}$ Nos outros dois empreendimentos de Goiânia viabilizados por empreitada, não foram previstos quaisquer equipamentos que desempenhassem esse papel.

${ }^{55}$ À exemplo do equipamento coletivo.

${ }^{56}$ Segundo Dicionário Melhoramentos da Língua Portuguesa, Edição Especial, São Paulo: Melhoramentos, 1988 (p.110) "assistência, s.f. (...) 4. Ajuda, Socorro, amparo." e "assessoria, s.f.(...) órgão ou conjunto de pessoas que assessora um chefe.". Os significados de cada uma das palavras mostram qual o sentido atribuído à cada uma dessas atividades, respectivamente, relacionadas ao apoio técnico empreendido à indivíduos que não tem meios para pagar pelo serviço, e o segundo apoio técnico desenvolvido por uma equipe que se pretende interdisciplinar e empreendido ao grupo organizado de famílias.

${ }^{57}$ Diversos autores tratam da importância do papel desempenhado pelas Assessorias Técnicas nos processos de autogestão na produção habitacional, entre eles BONDUKI (1992), RONCONI (1995), FELIPE (1997), AMARAL (2001), ARANTES (2002), CARVALHO (2004), entre outros.
} 
"A gente sempre traz alternativas que quando as pessoas começam a acreditar que aquilo ali pode ser para eles, desperta... que o cara não precisa ser semi-analfabeto quando sai da escola pública, ele não precisa ser tratado super mal pela saúde pública, ele não precisa morar super mal porque é um financiamento público.(...)" (Ricardo Gabini, 10.03.2008).

As assessorias técnicas mostraram que é possível fazer diferente ao desenvolver projetos com qualidade por meio da participação das famílias, ainda que esse processo apresente limitações. Diversos trabalhos acadêmicos desenvolveram considerações a respeito dos processos de participação e autogestão nos mutirões viabilizados pelo FUNACOM e pelos programas do governo do estado de São Paulo ${ }^{58}$. Apesar de ressaltarem os aspectos positivos alcançados pelas experiências, não deixaram de ponderar sobre, por exemplo, os limites inerentes ao processo participativo que em muitas situações limitam-se a processos consultivos (CARVALHO, 2004), e em relação ao autoritarismo e a outros valores arraigados à sociedade brasileira reproduzidos nas relações de micro poder internas ao mutirão (SILVA, 1994).

Entretanto, não se pode perder de vista que certos paradigmas incorporados à sociedade, bem como a "carga alienante" presente nas relações familiares, na escola, no trabalho e na história social (SINGER, 2005) podem ser modificadas por ações contínuas e de longa duração, que desafiem a ordem vigente e que devam ser a todo tempo estimuladas. Portanto, trata-se de um processo em construção, do qual não podemos esperar transformações rápidas e plenas.

Tem-se claro também que o fato motivador do envolvimento das famílias nos processos de luta, nesse caso pela moradia, é econômico e derivado da privação (BONDUKI, 1995). Mas, percebe-se que ao final dos processos autogeridos, apesar dos limites existentes as famílias encontram-se minimamente transformadas em decorrência desta experiência, pois passam a vivenciar na prática princípios antes distantes de sua vida cotidiana.

O trabalho desenvolvido em parceria entre movimento popular e assessoria foi o que permitiu às famílias dentro do processo coletivo a possibilidade de ter opinião, de decidir, de respeitar a opção do outro, e com isso trazer à habitação popular um pouco de estética ${ }^{59}$. $\mathrm{E}$

\footnotetext{
${ }^{58}$ SILVA, (1994), RONCONI (1995), FELIPE (1997), AMARAL (2001), ARANTES (2002), CARVALHO (2004) e outros.

${ }^{59}$ Retomando à expressão utilizada pelo Presidente na Abertura da Primeira Conferência Nacional das Cidades em outubro de 2003.
} 
o resultado alcançado foi uma qualidade que rompe com os partidos urbanísticos usuais e impõe outra referencia do que pode ser habitação popular, seu processo de produção e transformação social.

Nos processos decorrentes da implementação do Programa Crédito Solidário, percebemos que em nenhum momento essa parceria com a assessoria técnica foi estimulada de fato e tão pouco foi tomada por parte do Ministério das Cidades como diretriz do programa. Nem mesmo pela CEF, ainda que a ausência de assistência técnica às associações, tenha sido apresentada em 2005, como justificativa ao baixo desempenho do Programa, conforme citado no capítulo anterior ${ }^{60}$.

Considerando que o desenho do Programa foi formatado pela CEF sem conhecer e considerar a realidade dos movimentos populares, tão pouco o princípio da autogestão e as experiências ocorridas anteriormente, por mais desejável, não poderíamos esperar que fossem promovidos processos de capacitação e divulgação sobre o assessoramento técnico às associações nos moldes experimentados em São Paulo buscando, por exemplo, criar uma rede de assessorias, essencial para difundir pela prática o princípio da autogestão no Brasil.

Após os pontos levantados, tem-se claro que o Crédito Solidário não é o programa que estimula a ação autogerida, por outro lado não podemos negar que ele apresenta possibilidades e brechas para se fazer diferente. Nesse sentido as experiências citadas de Salvador, São Paulo, Santos, Porto Alegre, Belo Horizonte, Rio de Janeiro, mostram isso.

Infelizmente, sem que outro repertório do que pode ser a habitação popular fosse construído junto com a divulgação e implementação do Programa nos mais diferentes cantos do país, o que se viu foi a reprodução do velho padrão de HIS difundido pelo BNH e pelas políticas posteriores.

\footnotetext{
${ }^{60} \mathrm{O}$ debate sobre a assistência técnica esteve presente na pauta do Ministério das Cidades em 2005 quando foram organizados diversos seminários regionais com o propósito de se discutir a importância dessa ação e o modelo a ser viabilizado. O resultado desses seminários foi a formulação do projeto de lei da assistência técnica aprovada recentemente (Lei Federal № 11.888 de dezembro de 2008). Um ganho significativo para que se busque qualificar as intervenções de interesse social, especialmente àquelas ocorridas individualmente. Não podemos deixar de lembrar que existem financiamentos para aquisição de material de construção, como o Construcard - CAIXA e uma das modalidades da Carta de Crédito Individual, que não exigem projeto, comprovação de responsabilidade técnica, nem de documentação fundiária, o que nos leva a imaginar que parte desses recursos tenham contribuído, por exemplo, para promover o adensamentos de assentamentos precários. Respondendo às diretrizes da Lei Federal nำ11.888/2008 e relacionadas à maneira como essas ações de assistência técnica venham a ser montadas, especialmente se integradas à outras intervenções de regularização fundiária, por exemplo, poderão trazer impactos positivos às cidades.
} 
Com exceção de Belo Horizonte, Rio de Janeiro e São Paulo e guardadas as suas peculiaridades, no restante do país não existe a figura da assessoria técnica. Em geral são profissionais, engenheiros e arquitetos, que desenvolvem os projetos com base no senso comum do que é habitação popular, e provavelmente, nunca se perguntaram o que poderia ser feito de diferente para atribuir melhor qualidade (com menor custo) àquela habitação. Seja porque até então nunca tinham desenvolvido projetos para HIS, pois quem sempre atuou nessa frente foi o poder público, ou porque nunca tiveram a oportunidade de trabalhar com grupos organizados e vê-los como cidadãos.

"Aí, por exemplo, lá no Maranhão... Quem é o engenheiro da obra? É um rapaz super boa gente, lá da igreja... Ele toca obra privada e tal. E ele fez o melhor que ele pôde fazer, com o dinheiro que ele tinha disponível, e lá o dinheiro era bem pouco. (...) Agora é exatamente um conjuntinho de 300 casas enfileiradinhas assim... Em comparação com as outras casas produzidas para a mesma faixa de renda em São Luiz, dizem que é muito melhor... mas, tem a cara de conjuntinho habitacional de tudo quanto é lugar que a gente vai.(...) Esse rapaz por exemplo, nunca que teve contato com outra experiência parecida. Então... gera uma pergunta inevitável: Todo esse sacrifício valeu a pena, acrescentou alguma coisa na qualidade de vida dessas pessoas que vão morar nessas casas?” (Evaniza Rodrigues, 27.02.2008)

Apesar da maioria dos empreendimentos do PCS apresentarem uma qualidade absolutamente discutível, notamos naqueles movimentos nos quais esse outro repertório não faz parte de sua história, uma satisfação imensa ao empreender, pela primeira vez e a partir da administração direta, um conjunto habitacional.

"Eu também tenho críticas, que podia ser melhor, menos burocrático... mas eu reconheço como um programa muito especial. (...) porque os movimentos lutaram a vida toda para que fosse dado a eles um crédito... porque todos os programas que tem crédito são as prefeituras e os estados. Movimento não tem crédito, tem luta..." (Dona Bézinha, 01.04.2008).

Satisfação que foi explicada pela possibilidade de também proporcionar às famílias envolvidas no processo uma mudança de postura em relação ao mundo, ainda que esse potencial pudesse ter sido um dia, exponencialmente, maior.

"Por que quando você faz com o povo, você tem um sentimento que todo mundo cresce junto... Tinha gente que nem sabia entrar na CEF. Você acredita? Eu 
levava, e dizia 'gente essa é a nossa gerente. Quando vocês precisarem, vocês vêem e falem com ela, que ela está à disposição', e o povo começava a dialogar com a gerente. Isso é bom demais..." (Dona Bézinha, 01.04.2008).
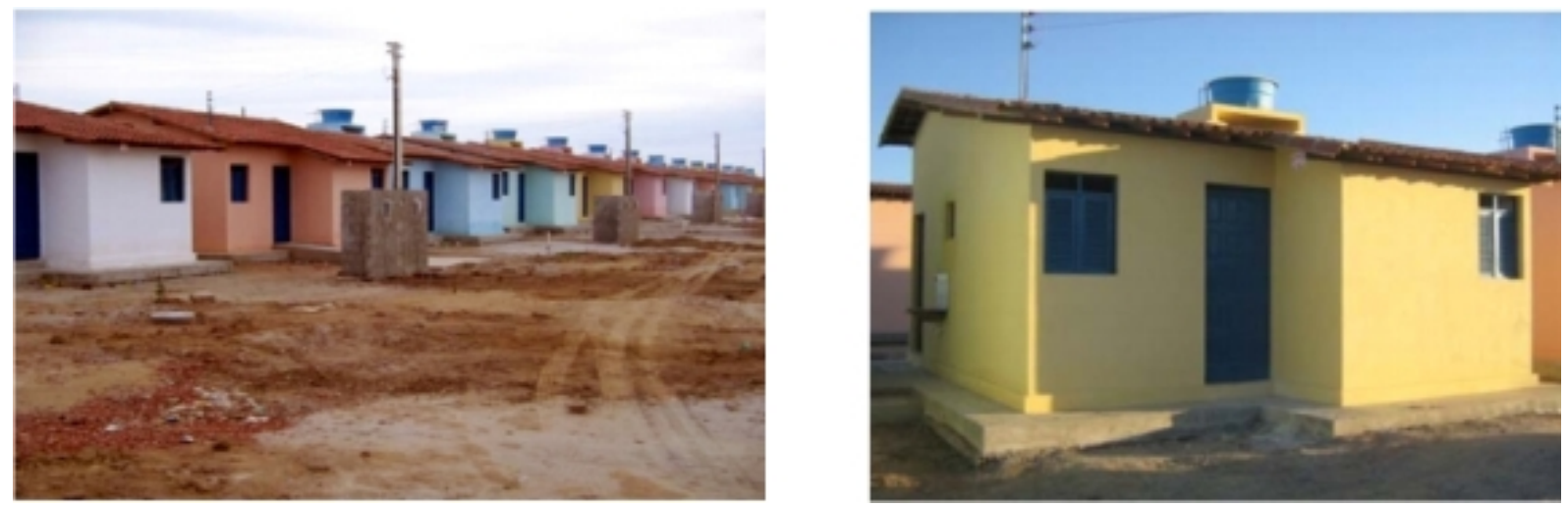

"É uma casinha de primeiríssima qualidade... que a gente discutiu desde o traço da massa, a telha que ia pra lá. Tudo foi feito teste na universidade, tudo foi qualificado. (...) Tem 37,2m2. Você às vezes entra numa casa de 40m2 ela não é tão grande porque não é bem aproveitada. Mas lá é um aproveitamento, que você não tem espaço a toa... sala ampla, nunca vi cozinha de casa popular do tamanho que é a nossa..." (Dona Bézinha, 01.04.2008, sobre o Empreendimento Parque Sul, João Pessoa, PB.)

fonte: www.cidades.gov.br

\subsubsection{A (re) reestruturação do Programa.}

Como se viu, nos primeiros anos de implementação do Crédito Solidário a CEF parecia reticente em relação ao Programa e pouco flexível aos problemas enfrentados e apontados pelas associações, mesmo tratando-se de um banco público que deveria ter como premissa o desenvolvimento social e econômico e não o lucro fiscal e financeiro. Postura que nos induzia a pensar que as dificuldades geradas na implementação do Programa tinham como fim criar obstáculos e negar a proposta que contrariava os padrões usuais arraigados pelo banco $^{61}$.

As lideranças dos movimentos populares, quando questionadas sobre suas experiências com o Crédito Solidário, apontaram uma série de problemas e dificuldades para concretizar suas propostas, mas foram unânimes em defender a continuidade do Programa.

\footnotetext{
${ }^{61}$ A mesma situação foi descrita por BONDUKI (1992) sobre a postura da prefeitura de São Paulo, em relação às propostas apresentadas para viabilizar os projetos do Recanto da Alegria e da Vila Arco-Iris, no Grajaú. A suposta repetição de postura adotada pela CEF vem reafirmar as dificuldades em romper com as tradições e lógicas arraigadas pelas instituições burocráticas.
} 
“... Nós temos que continuar apostando no Crédito Solidário, e tem que ter mais dinheiro, porque com essa nova sistemática, agora, tem aspectos positivos..." (Bismarque Miranda, 0104.2008).

Em 14 de janeiro de 2008 foi publicada a Resolução nํ121 do CCFDS responsável pela reestruturação do programa. A principal novidade foi a criação de uma conta equalizadora por cada empreendimento que recebe recursos (onerosos e não onerosos) do FDS $^{62}$ e além de possível aporte de caução financeiro ${ }^{63}$.

A concepção da conta estabilizadora possibilitou a redução das responsabilidades financeiras das famílias, permitiu a adoção de regras um pouco mais flexíveis pelo programa, e tem por traz a criação de meios para eliminar os riscos do agente operador e reduzir os riscos do agente financeiro ${ }^{64}$. Trata-se do mesmo principio utilizado no momento da elaboração do PCS, descrita no capítulo anterior. Um banco só consegue efetivar o programa de características sociais, que demanda subsídios e maior flexibilidade, se estiver assegurado contra os riscos financeiros (ter o pagamento dos custos de operação e assegurar as garantias) do agente operador do FDS e do agente financeiro do Programa.

Os recursos desta conta estabilizadora são investidos à taxa de mercado ao longo do período de carência e amortização. Conforme declaração da gerente da Superintendência de Fundos de Governo da CEF "antes eu estava utilizando o recurso só para pagar despesas ${ }^{65}, e$ hoje estou utilizando recursos para gerar recursos." (Claudia Gomes, 24.03.2008).

Os recursos gerados no mercado financeiro ao possibilitar o pagamento dos seguros, das taxas de análise cadastral e da correção monetária do valor de financiamento durante a fase de obra e amortização, eximem do beneficiário final a responsabilidade sobre esses encargos, reduzindo assim os valores das prestações. Em situações em que venha ocorrer aporte de caução financeiro realizado por agente público, privado ou pelas próprias

\footnotetext{
${ }^{62}$ A conta equalizadora pode ser composta por recursos onerosos do FDS equivalente ao percentual de $20 \%$ do Valor de Financiamento (VF) concedido; por recursos não-onerosos do FDS em percentual que varia em função do prazo de amortização e carência, podendo atingir o máximo de $50 \%$ do VF; somados ao retorno do financiamento pelo beneficiário final. A conta pode ainda, receber caução financeiro de no mínimo $10 \%$ do VF.

${ }^{63}$ Nos novos empreendimentos é facultado aplicar caução financeiro de no mínimo $10 \%$ do valor financiado.

${ }^{64} \mathrm{O}$ risco de crédito passou a ser garantido pelo próprio FDS, restando então ao agente financeiro apenas o risco da obra.

${ }^{65}$ Os subsídios aplicados eram em torno de $43 \%$ do Valor Financiado destinados ao pagamento das despesas como as taxas de administração, de equilíbrio e de risco do agente operador.
} 
cooperativas, os descontos no valor das prestações são ainda mais significativos e podem alcançar cerca de $40 \%$ do valor definidos pelo modelo anterior.

“... Se eles antes, para financiamento de $R \$ 30.000,00$ pagavam uma prestação de $R \$ 154,00 \ldots$ no total $R \$ 165,00$ porque tinha o seguro. Eles passarão a pagar $R \$ 92,00 . "$ (Claudia Gomes, 24.03.2008).

A criação da conta estabilizadora permitiu além do atendimento de famílias com rendimentos menores, o atendimento de no máximo 5\% de beneficiários acima de 60 anos por empreendimento, antes proibido ${ }^{66}$. Foi possível também flexibilizar a análise cadastral, na qual $20 \%$ das famílias podem ter cadastro comprometido com SERASA e SPC, por outro lado a obrigatoriedade de demonstrar capacidade de pagamento e a controle rígido em relação à inadimplência permaneceram.

“... se o cara ficar inadimplente hoje, apesar da CEF (agente financeira) ser apenas prestadora de serviço, pois o risco é do FDS, a CEF é obrigada a tomar a casa do cara. A gente (agente operador do FDS) vai remunerar ela por isso. O que a gente não quer é não pagamento por oportunismo, por isso o contrato individual." (Claudia Gomes, 24.03.2008).

Buscando estimular a adimplência foram criados benefícios como o desconto de $10 \%$ do valor da parcela mensal ao realizar o pagamento na data do vencimento. $E$ ainda, se o grupo estiver $100 \%$ adimplente até o último dia do mês em relação às parcelas devidas, 5\% do valor das prestações mensais serão repassadas à associação ou cooperativa responsável pelo grupo, possibilitando a ela a aplicação do recurso à obra ou o desconto das próximas prestações. Curiosamente a ação e organização coletiva e cooperada passaram a ser estimuladas pelo aspecto financeiro.

O mesmo aspecto pode ser identificado na criação da garantia responsabilidade solidária. Em situações onde existam beneficiários que não estejam aptos a oferecer garantia real, cinco titulares ficarão responsáveis pela dívida, caso ocorra inadimplência. Essa garantia pode ser aplicada somente até 72 meses pós-obra. Depois disso a CEF entende que

\footnotetext{
${ }^{66}$ Ainda sim o questionamento levantado por Gaboni (2008) merece ser mencionado: "Se a pessoa tem 61 anos, 'qual é a garantia?'...bom, é programa social ou não é? O Brasil espera que um brasileiro que tem 61 anos não tenha mais direito de ter casa? É isso que o governo federal está determinando (...) Perdeu pelo prazo. Como não resolveu antes, já era!".
} 
as famílias terão condições mais estáveis e a partir daí deverá ser feita a alteração para alienação fiduciária.

Muitas foram as reclamações à $\mathrm{CEF}$, em relação às dificuldades encontradas pela falta de flexibilidade nos processos de medição e dos atrasos dos desembolsos dos recursos às associações que acarretavam em problemas na execução da obra:

"Belo Horizonte, por exemplo, eu tinha uma visão totalmente diferente. Eles falavam que queriam liberação parcial, e eu falava 'de jeito nenhum, a norma é essa e eu vou cumprir.' E quando eu fui lá vi o problema deles, 'é, dá para se pensar...' Vai ter que mudar a norma, o conselho vai ter que aprovar, mas dá." (Claudia Gomes, 24.03.2008).

A nova resolução acatou propostas levantadas pelo movimento e passou a permitir a antecipação das liberações mensais condicionado à medição e comprovação de que a etapa prevista no cronograma já esteja finalizada e ainda, ao final do mês, caso a etapa anterior não tenha sido totalmente executada, passa a ser permitido, com justificativa do agente financeiro, o desembolso parcial dos recursos ${ }^{67}$.

A decorrência mais significativa dentre essas alterações, é a possibilidade que foi aberta para eliminar a obrigatoriedade de individualizar o processo ainda na etapa pré-obra, já que o empreendimento está assegurado durante todo o período da construção, e com isso desenvolver processos onde a lógica coletiva seja predominante.

O CCFDS reservou para o ano de $2008 \mathrm{R} \$ 250$ milhões destinados ao financiamento, $\mathrm{R} \$ 110$ milhões para subsídios e mais $\mathrm{R} \$ 50$ milhões destinados à conta equalizadora. Até o mês de novembro de $2008^{68}$ haviam sido contratados 106 novos empreendimentos, no valor total de $\mathrm{R} \$ 122.386 .317,15$ para viabilizar 7.019 atendimentos habitacionais, alcançando assim quase $50 \%$ da meta financeira estabelecida para o ano.

\footnotetext{
${ }^{67}$ Item 11.i.1 e item 11.i.2 da Resolução no121 do CCFDS de janeiro de 2008.

${ }^{68}$ www.cidades.gov.br, consultado em 07 de janeiro de 2009.
} 


\section{Gráfico 15}

Distribuição dos percentuais do déficit habitacional urbano (2006) $X$ atendimentos habitacionais do PCS (2005-2007) e PCS (2008), por região



Elaboração própria

fonte: www.cidades.gov.br e (BRASIL/MCID/SNH, 2008).

A partir do Gráfico 15 foi possível observar que a "agenda invertida" do Programa Crédito Solidário se perpetua. As distribuições regionais dos contratos e das unidades habitacionais mostram que o Rio Grande do Sul confirma a tendência apresentada até 2007 de viabilizar grande quantidade de contratos para promover pequenos empreendimentos distribuídos pelos municípios rurais. Somente em 2008 nesse estado foram 580 atendimentos habitacionais contratados nos municípios tipo I (224uh), J (219uh) e K (137uh). Ainda na região sul outra parte significativa dos empreendimentos foram pleiteados por cooperativas de municípios tipo B (440uh) pertencentes a aglomerados urbanos de Santa Catarina e Rio Grande do Sul.

A região Centro-oeste novamente se destacou ao ter aumentado consideravelmente o número de atendimentos habitacionais realizados. Especialmente por causa das associações do estado do Mato Grosso do Sul que contrataram quase $60 \%$ do total da região com 1.399 unidades habitacionais. Dentro desse total, cerca de $1 / 3$ de unidades foram viabilizadas em municípios médios (tipo G com 441 unidades habitacionais), e em pequenos municípios em espaços rurais pobres (tipo J com 362 e tipo K com 356 unidades habitacionais). 


\section{Gráfico 16}

Distribuição do percentuais do deficit habitacional Urbano (2006) $X$ atendimentos habitacionais PCS (2005-2007) e PCS (2008), por tipo de município do PLANHAB.

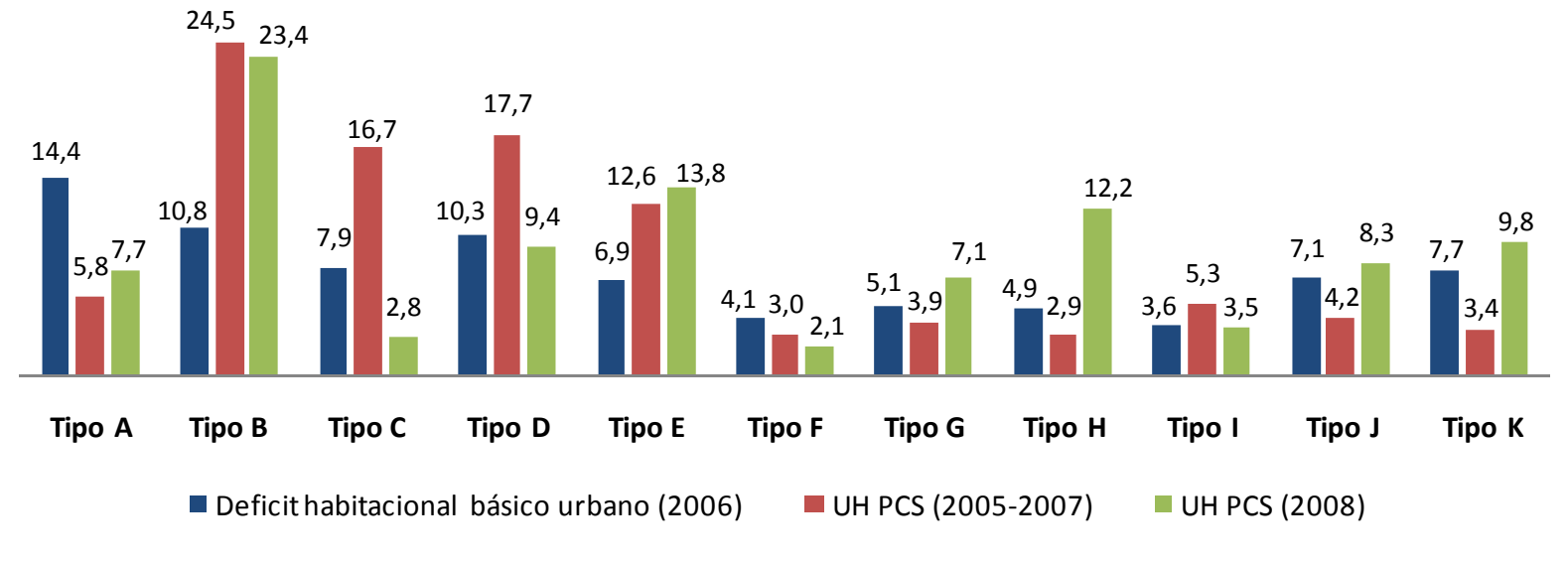

Elaboração própria

fonte de dados: (BRASIL/MINISTÉRIO DAS CIDADES/ SECRETARIA NACIONAL DE HABITAÇÃO/ CONSÓRCIO

PLANHAB, 2009) e www.cidades.gov.br.

Já o Gráfico 16 mostra que, diferente do que vinha ocorrendo até 2007, os atendimentos realizados nos pequenos municípios de espaços rurais (I, J e K), ocorreram proporcionalmente bem às necessidades habitacionais existentes.

Outra alteração significativa foi o incremento dos atendimentos realizados em municípios tipo $\mathrm{H}$ (centros urbanos em espaços rurais com elevada desigualdade e pobreza). Nos casos localizados no estado do Maranhão, que se destacou com 1.395 unidades habitacionais contratadas, foram 455 atendimentos em municípios do tipo $\mathrm{H}$, e mais 840 unidades contratadas por associações dos municípios do localizados em aglomerados urbanos do estado (tipo E).

Conforme apresentado no início deste capítulo, até 2007 tínhamos um cenário no qual o PCS não respondia às necessidades habitacionais dos locais que concentram o maior percentual do déficit habitacional urbano (regiões metropolitanas do Rio de Janeiro e de São Paulo), bem como o maior percentual do déficit habitacional rural (2843 municípios distribuídos entre os tipos J e K). E ainda, atendia prioritariamente associações localizadas em municípios consolidados e prósperos onde, proporcionalmente, o quadro das necessidades habitacionais não é tão latente.

Nos municípios pertencentes aos dois mais populosos aglomerados urbanos do País (São Paulo e Rio de Janeiro) constatamos que a partir da nova resolução de 2008 , apesar do PCS ter viabilizado mais contratados em São Paulo, não ocorreu uma alteração de tendência. 
Por outro lado o PCS passou a ter entrada um pouco mais significativa ${ }^{69}$ nos municípios pobres de áreas rurais, sejam eles médios ou pequenos.

Trata-se de um aspecto positivo e que suscita novas questões. 0 baixo grau de organização social e a pequena capacidade administrativa dos pequenos municípios foram argumentos utilizados pela CEF para justificar a pouca contratação de empreendimentos pelo PCS, especialmente nos estados da região nordeste do país. Não se tem até aqui, subsídios para afirmar o que proporcionou essa mudança de perfil de atendimento em relação aos anos anteriores, tão pouco para afirmar se essa mudança representa uma tendência ou foi decorrência das alterações promovidas pela nova resolução, ou mesmo de uma situação particular. Será preciso acompanhar o desempenho do programa dos próximos anos para se chegar a uma conclusão.

As alterações trazidas pela nova resolução apesar de positivas, e representarem ganhos às reivindicações do movimento, explicitam um contra-senso do Programa que somente teve seu caráter social ampliado pela introdução de mecanismos financeiristas para a operação do Programa. Outra contradição é que a incorporação formal do termo autogestão $^{70}$, entre as formas de atuação possíveis, e a incorporação da empreitada global ambas na resolução nำ121 ${ }^{71}$. Fato que nos leva a confirmação de que pouco importa os meios pelos quais a habitação é produzida, já que essas duas formas de atuação apresentam propósitos e princípios antagônicos.

Ao final de 2008 totalizaram-se R\$ 316 milhões contratados, distribuídos em 284 empreendimentos, destinados ao atendimento habitacional de 19.142 famílias.

\subsection{0 lugar da autogestão na política habitacional do Governo Lula}

Ao avaliarmos a implementação do programa e apontar as dificuldades e possibilidades na prática decorrentes do seu desenho operacional, percebemos que na ciranda de forças em torno da proposta prevaleceu a perspectiva da CEF, e paradoxalmente,

\footnotetext{
${ }^{69}$ É bom lembrar que esse olhar tem que ser sempre de proporcionalidade e não em números absolutos.

${ }^{70}$ Ao percorrermos os manuais da CEF, as resoluções do CCFDS, as instruções normativas do Ministério das Cidades, enfim, os documentos oficiais referentes ao Programa Crédito Solidário não foram encontrados, nem uma única vez, o termo autogestão.

71 “... c) administração direta e autogestão pelas cooperativas, associações e demais entidades da sociedade civil, d) empreitada global ..." (Resolução no 121 do CCFDS de 2008).
} 
um programa de caráter social foi regido por critérios financeiros que permitiram, especialmente a partir de 2008, maior flexibilidade ao atendimento de famílias de menor renda.

Avaliamos que essa perspectiva tem prevalecido na Política Nacional de Habitação em implementação e também na elaboração do Plano Nacional de Habitação. Inclusive, alguns aspectos que foram formulados pela CEF buscando viabilizar o Programa Crédito Solidário, a exemplo do Fundo Garantidor e o princípio da conta equalizadora, foram incorporados pelo PlanHab aos modelos de seguros e garantias, como mecanismo capaz de proporcionar o financiamento de crédito às faixas de menor renda ${ }^{72}$.

Não podemos negar, dentro da lógica financeirista da CEF, que esses aspectos representam avanços e benefícios à ação pública. Assim como a aplicação de subsídios às operações de crédito às famílias de baixa renda deixou de ser encarada como uma heresia, e passou a ser fato dado para enfrentamento da questão habitacional.

Apesar desses avanços conquistados que, buscando colocar nos mesmos termos do banco, proporcionaram condições mais favoráveis para se ter "devedores mais saudáveis", não significa que foram criadas condições favoráveis e esperadas para proporcionar o fortalecimento dos grupos organizados envolvidos no processo produtivo de suas habitações, tornando-os "combatentes mais persistentes e conscientes". Nem tão pouco foram criados meios para se garantir um "pouco de estética" às moradias e qualidade ambiental ao partido urbanístico, reincidindo no erro de produzir fragmentos de cidades que não proporcionam “a dignidade, a auto-estima, a respeitabilidade das pessoas"

Infelizmente, não foram criadas as condições favoráveis e esperadas para romper com a falta de tradição de se trabalhar com a prática autogestionária no país ${ }^{74}$. Assim, não podemos afirmar que exista de fato no atual governo um lugar definido na política

\footnotetext{
72 Segundo Relatório de gestão e prestação de contas do FDS (2005) a criação do Fundo Garantidor foi considerada "...inovação em termos de financiamentos habitacionais uma vez que permite aos agentes finais alcançarem segmentos da população antes excluídos da obtenção de tais empréstimos." (p.4).

73 Não foram respondidas às expectativas anunciadas pelo Presidente Lula, em discurso da Abertura da Primeira Conferência Nacional das Cidades, em outubro de 2003.

${ }^{74}$ Conforme Bonduki, " ... a falta de tradição pode ser superada (como foi no Uruguai) desde que o governo crie condições favoráveis à sua propagação, sobre tudo, liberdade para a criação de cooperativas habitacionais autônomas, condições estimuladoras de financiamento e regulamentação de assessorias técnica independente." (1992, p.163).
} 
habitacional para a autogestão ${ }^{75}$. E, por isso o programa que poderia ter o potencial de surpreender os céticos e emocionar os apaixonados ${ }^{76}$, resultou em frustração para aqueles que tinham a perspectiva (ou ilusão) ${ }^{77}$ de difundir o princípio da autogestão pelo Brasil.

\footnotetext{
75 Vale destacar que nos Programas de Governo do Partido dos Trabalhadores (PT) de 1994 e 1998 a autogestão aparece como uma das propostas contidas nas diretrizes que se referem à Reforma Urbana: "É fundamental o apoio financeiro e institucional aos movimentos sociais organizados (mutirões. cooperativas. associações, etc.) buscando incentivar a autogestão popular. Dentro desse princípio, deverão ter apoio ainda, as parcerias governo federal/cooperativas sindicais para a produção de novas moradias." (Programa de Governo do PT de 1994) e "Formulação de programas que potencializem a participação de ONGs, cooperativas e movimentos sociais na implementação da política habitacional, através de processos autogestionários $e$ cogestionários". (Programa de Governo do PT de 1998).

${ }^{76}$ Referência ao trecho da introdução do Livro de Bonduki (1992) Habitação e autogestão: construindo territórios de utopia, onde o autor descreveu: “... ao conhecer esses mutirões os céticos se surpreendem e os apaixonados se emocionam."
}

77 "A gente tinha na cabeça que o Crédito Solidário ia impor a idéia de autogestão no Brasil, e isso era uma ilusão...". Leonardo Pessina em entrevista realizada em 19 de março de 2008. 
5

\section{Considerações finais}

"Não basta transformar o Estado. É necessário transformar concomitantemente a sociedade existente, para impedir que uma minoria continue a manter indefinidamente certas posições-chaves e estratégias para exercício da monopolização do Estado" (Florestan Fernandes em artigo publicado na FSP de 24 de abril de 1989 apud GOHN, 1991)

Buscamos com essa dissertação contribuir para a reflexão a cerca da produção habitacional autogerida destinada ao atendimento da população de baixa renda. Para compreender a importância atribuída à autogestão pelo atual governo federal em sua política habitacional, nos propormos analisar os processos de pleito, elaboração, operacionalização e implementação do Programa Crédito Solidário, que tem como particularidade a possibilidade da autogestão, definido como o nosso instrumento de análise. Para construí-la adotamos a perspectiva histórica da interação entre Estado e sociedade civil, ao entendermos que a reivindicação deste programa habitacional feita pelo movimento popular e respondida pelo Estado, tratava-se apenas de um ponto preciso de uma trajetória.

Foi possível notar que a busca da sociedade civil organizada pela interlocução com o Estado nas diferentes esferas federativas, a partir do processo de redemocratização, passa a ser constante. E que ao longo dos anos a abertura e a qualidade do diálogo entre Estado e a sociedade civil oscilou em função dos atributos da ação governamental, do amadurecimento das relações sociais e da institucionalização da sociedade civil organizada. Esta interação diferenciada, quer no tempo, quer no espaço, foi capaz de gerar experiências democráticas mais ou menos vivas e, ainda, o fortalecimento ou arrefecimento dos movimentos populares.

Em decorrência dessa oscilação de posturas do Estado relativas à participação, a sociedade civil organizada encontrou, principalmente, nos governos de esquerda pautados pela democracia participativa, a possibilidade de disputa e efetivação de suas propostas. Percebe-se então o direcionamento da demanda política dos movimentos populares para 
estes governos, deslocando, em alguns momentos, a pressão de governos estaduais e municipais que possuem responsabilidade política e social mas não possuem uma gestão democrática.

Particularmente no âmbito federal os processos de participação popular iniciados ainda no momento da redemocratização somente tiveram continuidade no Governo Lula, e apresentaram os velhos dilemas relacionados à qualidade dos processos participativos, similares àqueles enfrentados na esfera local nos anos 90. A participação dos movimentos populares nos processos participativos da via institucional levou à efetivação de mecanismos político-institucionais que deslocaram atuação destes para as arenas coorporativas e que privilegiaram a organização de aparelhos de poder e busca por status em detrimento da organização social.

Em 2003 o PT chega ao governo sem alcançar o poder. Definiu-se um campo político amplo e diverso, sem um projeto de Nação. Resultando em um Estado com inúmeras contradições em decorrência da constante mudança no equilíbrio de forças existentes dentro dele. A presença de grupos divergentes, até mesmo com interesses antagônicos, dentro do mesmo governo impôs a necessidade de negociação constante para que propostas historicamente presentes nas pautas do PT fossem efetivadas (muitas vezes com perdas), e com isso foram colocados limites à influência e impostas derrotas aos setores populares. O que se viu no atual governo foram mais continuidades do governo $\mathrm{FHC}$ do que as rupturas esperadas por aqueles que acreditavam em transformações mais profundas do Estado brasileiro após as eleições de $2002^{1}$.

Um exemplo é a aprovação do FNHIS que, em função das alterações impostas por setores mais conservadores do governo, descritas no terceiro capítulo, transformaram um projeto histórico, amplo e de caráter nacional, em uma lei fragmentada. O rebaixamento na negociação da proposta do movimento popular pelo Estado principalmente, ao extinguir a possibilidade das associações e cooperativas como agentes promotores do sistema nacional de habitação, estimulou a mudança de foco de disputa do movimento popular. Enquanto antes lutava pela aprovação de uma nova política habitacional que considerava outro modelo de sociedade, passou a pautar a questão particular da autogestão e do repasse

\footnotetext{
${ }^{1}$ Fala do Prof. Paul Singer em grupo de estudos, Brasília, agosto de 2008.
} 
direto dos recursos do FNHIS. Eis a contradição: somente este governo seria capaz de aprovar a Lei do FNHIS, ao mesmo tempo em que, aprovada com as reduções impostas na negociação, abriu-se mão da utopia de um novo modelo de sociedade?

As contradições do Estado também se revelam nas posturas da CEF (agente operador e principal agente financeiro da política urbana) subordinada ao Ministério da Fazenda e que muitas vezes contrariam diretrizes do Ministério das Cidades responsável pela gestão da política habitacional. O peso político atribuído à $\mathrm{CEF}$ nasce com a extinção do $\mathrm{BNH}$, quando o banco passou a ter responsabilidade de definir diretrizes da política habitacional durante os anos de fragilidade institucional do setor. Porém, mesmo após a criação do Ministério das Cidades, a influência da CEF na prática se dá tanto nas definições das orientações dos fundos que financiam a política habitacional, quanto na execução da política na ponta em função de sua inserção nos municípios, quer na operação dos programas, quer na contratação das propostas de financiamento e seu acompanhamento.

Se faltou ao governo um projeto de Nação, se revela, não raro, um projeto de poder explicitado na recorrente definição de diretrizes que produzam resultados quantitativos expressivos. Nesse sentido, o enfrentamento do déficit habitacional privilegiou produzir mais a menores custos. Optou-se pelo resultado certo da empreitada global nas periferias. Esta decisão significou abdicar da possibilidade de enfrentar a diversidade do déficit e pautar outro modelo de desenvolvimento como, por exemplo, a partir do incentivo e da implantação de propostas de habitação nas áreas centrais ou por produção autogestionária, que garantem uma maior qualidade e colocam em questão a lógica especulativa e produtiva preponderantes.

Hoje, o setor privado ainda é o principal interlocutor e desempenha maior influência nas definições de governo, haja visto o recente pacote de habitação ${ }^{2}$ que veio responder a conjuntura de crise econômica com uma política anticíclica. Essa ação imediata desenhada, em poucos gabinetes, visa essencialmente atender à classe média e responder aos interesses do setor da construção civil. A Secretaria Nacional de Habitação do Ministério das Cidades, que rompeu com a falta de planejamento no setor e constrói o Plano Nacional de

\footnotetext{
${ }^{2}$ Para saber mais consultar: http://www.novabrasilfm.com.br/noticias/nova-noticia/novo-pacote-dehabitacao-vai-beneficiar-a-classe-media/ ; http://www1.folha.uol.com.br/folha/dinheiro/ult91u105008.shtml ; http://www.agenciabrasil.gov.br/noticias/2009/02/13/materia.2009-02-13.7860993024/view .
} 
Habitação (PlanHab) como instrumento norteador da ação pública, nos pareceu neste processo contrariada e atropelada.

A institucionalização do Plano Nacional de Habitação como política pública para o setor foi prejudicada, para não dizer interrompida, por mais um pacote para justificar os significativos investimentos e os incentivos para impulsionar o setor privado a produzir habitação de mercado. Medida potencialmente indutora da valorização imobiliária, em decorrência do aquecimento do setor, e que conseqüentemente, poderá induzir o aprofundamento das desigualdades. Prevalece o interesse coletivo por meio de uma política pública, ou se cria factóides que respondem ao tempo político de uma crise financeira mundial? Seria possível outro modelo de intervenção a ser proposto pelo Estado para enfrentar a crise econômica? A sociedade brasileira estaria preparada para implementar um outro projeto de sociedade, a exemplo dos processos que vem ocorrendo na argentina de recuperação de empresas falidas a partir da formação de cooperativas de produção? Em qual escala? Quais os limites a serem enfrentados para efetivação de propostas nesses moldes?

Temos que destacar que dentro do mesmo governo existem processos em que o Estado tem fortalecido o movimento popular como seu interlocutor. A exemplo da Portaria nำ436 de 28 de novembro de 2008, da Secretaria do Patrimônio da União que orientou as Gerências Regionais do Patrimônio da União a criarem grupos de trabalho estaduais para discutir critérios para destinação de imóveis da União para programas de provisão habitacional de interesse social e fortalecimento da gestão democrática desse patrimônio. Entre outros objetivos, esses grupos de trabalho deveriam propor critérios para a transferência de áreas da União com vocação habitacional para associações e cooperativas de interesse social. Bem como a Instrução Normativa nำ47 de 8 de outubro de 2008 do Ministério das Cidades que regulamenta a ação de Produção Social da Moradia que parece, enfim, depois de aproximadamente um ano de construções coletivas entre governo e movimentos populares possibilitar o acesso direto dos recursos do FNHIS à associações e cooperativas. Ambas medidas reconhecem o movimento popular como agentes promotores e, consequentemente, respaldam o princípio da autogestão. No entanto, ainda é perceptível diferença de pesos atribuídos à influencia dos diferentes atores na ação pública. 
Em relação à perspectiva social, a experiência analisada mostrou que para efetivar os empreendimentos, ou mesmo para fazer parte dos canais institucionais de participação, o movimento é compelido à condução da tecnicidade dos processos administrativos. Entretanto, as soluções de certos impasses, vão além dos aspectos técnicos e financeiros esbarrando em aspectos intrínsecos à realidade brasileira. Como garantir o acesso à terra urbanizada em um mercado fundiário não regulado? Como enfrentar a burocracia estatal e conseguir a aprovação técnica, autorizações de concessionárias de serviços urbanos e licenciamentos ambientais? Sabendo que os aspectos políticos, em nossa tradição burocrática patrimonialista, muitas vezes se sobrepõem aos aspectos técnicos.

O movimento por um lado é obrigado a se capacitar para enfrentar a tecnicidade dos desafios impostos pelos programas governamentais, por outro enfraquece sua mobilização de bandeiras históricas uma vez que as lideranças legitimadas são poucas para ambas as frentes, ainda que se reconheça uma recente iniciativa de formação interna e ampliação de quadros. Qual a saída? Uma política nacional de assessoramento técnico para os movimentos populares? Ou uma política de formação para os movimentos populares? Cabe ao Estado formar os movimentos para estimular sua organização e fortalecer sua atuação?

Em relação ao debate sobre a assistência técnica apesar de presente entre as pautas do Ministério das Cidades, não foi ainda definido como prioridade visto que, em linhas gerais, o "padrão popular" dos velhos conjuntos se perpetuou nas novas intervenções habitacionais de interesse social produzidas pelo país, salvo exceções. O suporte técnico, social e jurídico, não foi encarado nem como instrumento de qualificação da intervenção urbanística e tão pouco de indução à transformação social. As diretrizes apontadas pelo governo se restringiram aos aspectos abordados pela nova Lei de Assistência Técnica (Lei Federal $\mathrm{n}$ - 11.888/2008), com tendência assistencialista ao induzir projetos individuais e em ações pontuais.

De toda forma esta lei representa um ganho que não pode ser desprezado, pois é capaz de qualificar as intervenções de interesse social, especialmente aquelas ocorridas individualmente por meio de financiamentos para aquisição de material de construção, que não exigem projetos, comprovação de responsabilidade técnica, nem documentação fundiária, e o que nos induz a conjeturar que parte desses recursos tenha contribuído, ao longo dos últimos anos, para o adensamento de assentamentos precários. 
Sabemos que a política habitacional dos anos 70, quando da ausência de diretrizes de um projeto de cidade justa, transformou os conjuntos habitacionais produzidos pelos poder público em espaços de exclusão, precariedade e violência. Qual a cidade que o Estado produz hoje? Apesar das importantes iniciativas tomadas por este governo como as campanhas dos Planos Diretores Participativos para incentivar a aplicação dos instrumentos definidos no Estatuto da Cidade e para fazer valer o função social da propriedade, somados ao ineditismo da elaboração de um Plano Nacional de Habitação que incorpora a política urbana e fundiária e um profundo quadro institucional e social do déficit habitacional no país, o nó da terra urbana continua a ser uma questão não enfrentada. Alimentada pelos modelos de expansão urbana que, especialmente nas cidades médias, continuam sendo de expansão horizontal e construção nas periferias, pautados pela lógica especulativa.

Temos que considerar os importantes avanços conquistados e as transformações apontadas, particularmente pela política habitacional desse governo, mesmo que esses não tenham atingido as expectativas daqueles que acreditavam na transformação do nosso país. Do mesmo modo, não podemos deixar de ressaltar que as transformações do Estado são lentas e incrementais, e que dependem, em grande medida, das pressões e ações externas que induzam de fato e a todo o momento às transformações almejadas. Sabemos também que todos os espectros ideológicos atuam no Estado e na construção dessas "pressões" e ainda se estabelecem de forma desigual.

O atual governo tem legitimidade ou matrizes capazes de induzir a uma guinada na política habitacional e urbana? O que pode ser feito para a estruturação de uma política pública transformadora? Como garantir avanços menos vulneráveis à vontade política?

Tais perguntas não possuem uma resposta direta, muito menos consistem no objeto deste trabalho. Ao mesmo tempo, elas se impõem quando estudamos quaisquer políticas públicas em uma perspectiva transformadora de nossa realidade desigual e perversa, principalmente em um governo que se afirma comprometido com as transformações sociais.

O debate sobre o fortalecimento da sociedade civil organizada, em especial dos movimentos populares é fundamental. Garantir recursos para programas que almejem este fortalecimento, bem como sua institucionalização em políticas públicas poderia ser um primeiro passo. Um outro projeto de sociedade poderia passar, neste campo, pela institucionalização de um Programa Nacional de Produção Social direcionado e obrigatório 
para estados e municípios que acessem recursos federais e que garanta como princípio a autogestão pelos beneficiários, como meio capaz de produzir projetos e construções de qualidade.

Também é essencial enfrentar, de fato, a questão da localização dos empreendimentos habitacionais de interesse social sabendo que para tanto, será necessário rever limites financeiros e diretrizes, inclusive para viabilizar habitação em áreas urbanas centrais. Ao lado disso, a diretriz de ampliação dos recursos habitacionais em nosso país deve ser considerada para que se possa reverter a lógica do quantitativo em detrimento à qualidade da cidade produzida. Para se produzir em escala e com qualidade, a aprovação da PEC n 285 de 2008 que amplia os recursos para habitação social, pode ser um caminho, contanto que se defina um novo direcionamento político diferente das decisões tomadas e das ações públicas atuais.

De outro lado, se não cabe ao Estado formar os movimentos populares para estimular sua organização e fortalecer sua atuação, é missão dele viabilizar condições de implementação de políticas que respondam a esses propósitos. Neste sentido, é fundamental a implementação de um Programa Nacional de Assessoria Técnica que atue para além da lei existente e possibilite o superte técnico, social e jurídico contemplando aspectos amplos capazes de garantir o acesso à moradia, à cidade e à cidadania.

Por fim, tratamos desses desafios como possíveis propostas de uma "Política Nacional" e não uma política federal. Temos claro que não cabe exclusivamente ao governo federal a responsabilidade por esta guinada, mas cabe ao governo federal definir os instrumentos para a difícil tarefa de fomentar a interlocução com demais órgãos institucionais e implementar, respondendo aos limites da união, estados e municípios, os anseios historicamente reprimidos dos setores populares na direção da construção de cidades mais belas, justas e democráticas.

Pois, como afirmou Florestan Fernandes, não basta transformar o Estado, é necessário transformar concomitantemente a sociedade existente. 


\section{Bibliografia de referência}

ABREU, Haroldo; LEITE, Márcia. Participação popular e hegemonia: desafios da política municipal. In: Revista Proposta no 54. Rio de Janeiro: FASE-RJ, ago/ 1992.

AMARAL, Ângela. Observatório dos direitos do cidadão: acompanhamento e análise das políticas públicas da cidade de São Paulo - Habitação. São Paulo: Instituto Polis/ PUCSP, 2001.

- Habitação, participação popular e cidadania. São Paulo: Dissertação de mestrado FAUUSP, 2001b.

ARANTES, Pedro. Arquitetura Nova: Sérgio Ferro, Flávio Império e Rodrigo Lefebvre, de Artigas aos mutirões. São Paulo: Editora 34, 2002.

ARRETCHE, Marta. Mitos da descentralização: mais democracia e eficiência nas políticas públicas? In: Revista Brasileira de Ciências Sociais, ano 11, no 31. Rio de Janeiro, 1996.

AZEVEDO, Sergio. Cap.01 - Desafios da habitação popular no Brasil: políticas recentes e tendências. In CARDOSO, A. (org). Habitação social nas metrópoles brasileiras: uma avaliação das políticas habitacionais em Belém, Porto Alegre, Recife, Rio de Janeiro, e São Paulo no final do século XX. Porto Alegre: CEF/ FINEP, 2007.

BALL, Michel. O desenvolvimento do capitalismo na provisão da habitação. In Revista Espaço e Debates no 36: São Paulo: NERU, 1992.

BARAVELLI, José. O cooperativismo uruguaio na habitação social de São Paulo: das cooperativas FUCVAM à Associação de Moradia Unidos de Vila Nova Cachoeirinha. São Paulo: dissertação de mestrado, FAUUSP, 2006.

BARBOSA, Itaque. O Estado e a produção habitacional pública. São Paulo: dissertação de mestrado, FFLCHUSP, 2008.

BOLAFFI, Gabriel. Habitação e urbanismo: o problema e o falso problema. In: MARICATO, E. (org). A produção capitalista da casa (e da cidade) no Brasil industrial. São Paulo: Ed. Alfa-ômega, 1979. 
BONDUKI, Nabil. Habitação e autogestão: construindo territórios da utopia. Rio de Janeiro: FASE, 1992.

(Org.). Habitat: as práticas bem-sucedidas em habitação, meio ambiente e gestão urbana nas cidades brasileiras. São Paulo: Studio Nobel, 1996.

. Origens da habitação social: arquitetura moderna, lei do inquilinato e a difusão da casa própria. São Paulo: Estação Liberdade/ FAPESP, 1998.

A luta pela reforma urbana no Brasil: do regime militar à criação do Ministério das Cidades, Seminário UTDU, Buenos Aires, 2003.

Política habitacional e inclusão social no Brasil: revisão histórica e novas perspectivas no Governo Lula, mimeo, 2008. Extraído do site: www.usjt.com.br, acesso em 10 de dezembro de 2008.

BRASIL. Ministério das Cidades. Cadernos Ministério das Cidades 4: Política Nacional de Habitação. Brasília: Ministério das Cidades, 2004.

. Realizações do Ministério das Cidades - Janeiro de 2003 a junho de 2004. Brasília. Ministério das Cidades, 2004b.

Ministério das Cidades. Resultados, projeções, ações. Brasília: Ministério das Cidades, 2008.

BRASIL. Ministério das Cidades. Secretaria Nacional de Programas Urbanos. Regularização fundiária. Brasília: Ministério das Cidades, 2005.

BRASIL. Ministério das Cidades. Secretaria Nacional de Habitação. Déficit habitacional no Brasil 2006. Brasília: Ministério das Cidades/Fundação João Pinheiro, 2008.

CADERNO 1 - Plano Nacional de Habitação: contribuições dos seminários regionais. Brasília: Ministério das Cidades, 2008b.

BRASIL. Ministério das Cidades. Secretaria Nacional de Habitação/Consórcio PLANHAB. Plano Nacional de Habitação - versão para debates. Brasília: mimeo, no prelo, 2009. 
BRASIL. Instituto de Pesquisa Econômica Aplicada - IPEA. Políticas sociais: acompanhamento e análise. Boletim no 14/ fev. de 2007. Brasília: IPEA, 2007.

- Objetivos de Desenvolvimento do Milênio: relatório nacional de acompanhamento. Brasília: IPEA/SPI-MP, 2007b.

. Comunicado da Presidência: PNAD-2007, primeiras análises: saneamento básico e habitação, v.5. Brasília, IPEA, 21 de outubro de 2008. Disponível em: http://www.ipea.gov.br/default.jsp

CARDOSO, Adauto. Política habitacional no Brasil: balanço e perspectivas. Observatório IPPUR/ UFRJ-Fase. Rio de Janeiro: mimeo, sem data.

. Desigualdades urbanas e políticas habitacionais. Observatório IPPUR/UFRJFase. Rio de Janeiro: mimeo, sem data.

CARVALHO, Caio. Lupa e telescópio: o mutirão em foco. São Paulo, anos 90 e atualidade. São Paulo: dissertação de mestrado FAUUSP, 2004.

CHAUÍ, Marilena. Conformismo e resistência: aspectos da cultura popular no Brasil. São Paulo: Brasiliense, 1986.

CONTI, Alfio. A experiência da autogestão em Ipatinga: uma busca pelo conceito. Belo Horizonte: Dissertação de mestrado, UFMG, 1999.

CORRÊA, Ricardo. Direito à terra e habitação, Vol II. Rio de Janeiro: Fundação Bento Rubião, 2007.

DAGNINO, Evelina (org). Dossiê: os movimentos sociais e a construção da democracia. In: Idéias - Revista do Instituto de Filosofia e Ciências Humanas da Unicamp. Campinas: IFCH-Unicamp, 1999.

DEMO, Pedro. Cidadania menor: algumas indicações quantitativas de nossa pobreza política. Petrópolis: Ed. Vozes, 1992. 
FAGNANI, Eduardo. População e bem-estar social no Brasil: 40 anos de ausência de política nacional de habitação popular (1964-2002). In: Revista Multiciência, no 6. Campinas: IE/Cesit/Unicamp, 2006.

FELIPE, Joel. Mutirão e autogestão no Jardim São Francisco (1989-1992): movimento de moradia, lugar do arquiteto. Dissertação de Mestrado. São Carlos: EECSC, 1997.

FREIRE, Paulo. Pedagogia da autonomia. São Paulo: Editora Paz e Terra, 2001.

FREITAS, Silvio. Habitação popular em Goiânia: Vila Mutirão, mil casas em um dia. Porto Alegre: Dissertação de Mestrado, UFRGS, 2007. Disponível em: http://www.ufrgs.br/labcon/mestrado/silvio freitas.pdf

FRUET, Genoveva. As cooperativas habitacionais de Porto Alegre: parcerias, realizações e desafios. In: Revista Ambiente Construído, v.4, n1, jan/mar, Porto Alegre, 2004. Disponível em: http://www.antac.org.br/ambienteconstruido/pdf/revista/artigos

GOHN, Maria da Glória. Movimentos sociais e luta pela moradia. São Paulo: Edições Loyola, 1991.

GRAZIA, Grazia de. A exclusão e os atores nacionais contemporâneos. In: Revista Proposta, no67. Rio de Janeiro: FASE-RJ, dez/1995.

GUILLERM, Alain \& BOURDET, Yvon. Autogestão: uma mudança radical. Rio de Janeiro: Zahar, 1976.

INSTITUTO CIDADANIA. Projeto moradia. São Paulo: Instituto Cidadania, 2000.

JACOBI, Pedro. Atores sociais e Estado: movimentos reivindicatórios urbanos e Estado dimensões da ação coletiva e efeitos político-institucionais. In: Espaço \& Debates, no26. São Paulo: NERU, 1989.

LANNOY, Camilo. O descompasso das políticas públicas para a solução do déficit habitacional. Brasília: Dissertação de mestrado. FAUUNB, 2006. 
LOPES, João Marcos; RIZEK, Cibele. O mutirão autogerido como procedimento inovador na produção da moradia para os pobres: uma abordagem crítica. São Carlos, mimeo, 2005.

MARICATO, Ermínia. Autoconstrução, a arquitetura possível. In: MARICATO (org). A produção capitalista da casa (e da cidade) no Brasil industrial. São Paulo: Alfa-ômega, 1979.

. Crise da moradia e Reforma Urbana. In: Anais da V Semana de Estudos Mā Augusta Albano, RJ, no206, Ano XX, 1988.

Metrópole na periferia do capitalismo. São Paulo: Hucitec, 1996.

. Política urbana e de habitação social: um assunto pouco importante para o Governo FHC. São Paulo: mimeo, 1998.

. Cidades: realizações do Governo Lula. mimeo, 2006.

MARTINS, Humberto. Reforma do estado na era FCH: diversidade ou fragmentação da agenda de políticas de gestão pública? In: RERE/Instituto Brasileiro de Direito Público, no10. Salvador, 2007. Disponível em: http://www.direitodoestado.com.br

MELO, Marcus André. Classe, burocracia e intermediação de interesses na formação da política de habitação. In: Revista Espaço \& Debates, no 24. São Paulo: NERU, 1988.

. Estruturação intra-urbana, regimes de acumulação e sistemas financeiros da habitação: Brasil em perspectiva comparada. In: Revista Espaço \& Debates, no. 31. São Paulo: NERU, 1990.

MORONI, José Antonio; CICONELLO, Alexandre. Participação social no Governo Lula. Avançamos? 2005. Disponível em: www.abong.org.br

MOYSÉS, Aristides. A produção de territórios segregados na região noroeste de Goiânia: uma leitura sócio-política. In: II Encontro "Democracia, Igualdade e Qualidade de Vida. O desafio para as cidades no século XXI". Belém, out. 2001. Disponível em: http://www.observatoriodasmetropoles.ufrj.br/download 
NASCIMENTO, Cláudio. Autogestão: palavra e idéia. In MELLO, S.; Barbieri, E; Sígolo, V. (org). Economia solidária e autogestão: encontros internacionais, v.2. São Paulo. NESOLUSP/ITCP-USP, 2007.

OLIVEIRA, Francisco de. Crítica à razão dualista. O ornitorrinco. São Paulo: Ed. Boitempo, 2003.

PAZ, Rosangela. Fundo Nacional de Moradia Popular: marco histórico da participação da União dos Movimentos de Moradia de São Paulo. São Paulo: Dissertação de Mestrado, Serviço Social PUC-SP, 1996.

PREFEITURA MUNICIPAL DE SALVADOR. SECRETARIA MUNICIPAL DE SALVADOR. Plano Municipal de Habitação de Interesse Social de Salvador (2008-2025). Salvador: PMS/SMS, jan.2008.

REVISTA PROPOSTA no 35, Mutirões habitacionais: da casa à cidadania. Rio de Janeiro: FASERJ, Ano XII, Set/1987.

REVISTA TEMPORAES, Edição Especial. Democracia e autogestão. São Paulo: Humanitas/ FFLCHUSP, ago/1999.

RIBEIRO, Ana Clara. Alguns traços da conjuntura política: movimentos sociais esfera pública. In: Revista Proposta, no67. Rio de Janeiro: FASE-RJ, dez/1995.

ROCHA, lêda. Participação cidadã em projetos habitacionais: a experiência do Programa Crédito Solidário em Belém. Brasília: monografia curso de especialização - UNB/CEF, jun/2007.

RODRIGUES, Evaniza; PESSINA, Leonardo e BARBOSA, Benedito. Produção Social da Moradia: desafios da política de habitação. In: Revista Proposta, no 116. Rio de Janeiro, FASERJ, jun/2008.

RONCONI, Reginaldo. Habitações construídas com gerenciamento pelos usuários, com organização da força de trabalho em regime de mutirão: o Programa FUNAPSComunitário. Dissertação de Mestrado. São Carlos: EECSC, 1995. 
ROYER, Luciana. Política habitacional no estado de São Paulo: estudo sobre a Companhia de Desenvolvimento Habitacional e Urbano do estado de São Paulo. São Paulo: Dissertação de Mestrado, FAUUSP, 2002.

SADER, Eder. Quando novos personagens entram em cena. Rio de Janeiro: Ed. Paz e Terra, 1988.

SANTOS, Carlos Nelson dos. Como e quando pode um arquiteto virar antropólogo? In: VELHO, G. (org.) O Desafio da Cidade. Rio de Janeiro: Ed. Campus, 1980.

SANTOS, Cláudio. Políticas federais de habitação no Brasil: 1964/1998. Texto para Discussão no 654. Brasília: IPEA, 1999.

SCHERER-WARREN, Ilse; KRISCHKE, Paulo. Uma revolução no cotidiano? Os novos movimentos sociais na América latina. São Paulo: Ed. Brasiliense, 1987.

SCHERER-WARREN, Ilse. Redes de movimentos sociais. São Paulo: Ed. Loyola/ Centro João XXIII, 1993.

SÍGOLO, Vanessa. Trabalho em moviment'ação': a formação de movimentos sociais de economia solidária no Brasil e na Argentina pós-90. São Paulo: dissertação de mestrado PROLAM-USP, 2007.

SILVA, Ana Amélia. (org). Moradia e cidadania: um debate em movimento. São Paulo: Revista Polis, n20, 1994.

SINGER, Paul e BRANT, Vinícius. São Paulo: o povo em movimento. Petrópolis, Ed.Vozes, 1980.

SINGER, Paul. Introdução a economia solidária. Ed. Fundação Perseu Abramo, São Paulo, 2002.

SOCRATES, Jodete. Dossiê Reforma Urbana - Lei de Desenvolvimento Urbano, São Paulo: FAUUSP/CESAD, julho 1986.

SOUZA, Leandro. A participação do futuro morador em projetos de habitacionais de baixa renda. BH, dissertação de mestrado, UFMG, 2007. 
STEINBERGER, Marilia. Território, ambiente e políticas públicas espaciais. Brasília: LGE Editora/ Paralelo 15, 2006.

VARGAS, Nilton. Racionalidade e não racionalização: o caso da construção habitacional. In: FLEURY, A.C.C. \& VARGAS, N. Organização do trabalho. São Paulo: Atlas, 1983.

VILLAÇA, Flavio. O que todo cidadão precisa saber sobre habitação. São Paulo: Global Editora, 1986.

VILANOVA, Mã de Fátima. Política pública de habitação popular com mediação de ONG: experiência Premiada no Habitat II. Fortaleza: Educe, 2005.

\section{Documentos consultados}

AMBIENTE ASSESSORIA TÉCNICA. Regulamento de obras - Condomínio de habitação de interesse social Colinas da Oeste. Mimeo, s/d.

AMBIENTE ASSESSORIA TÉCNICA/ SOMWY, Simone. Projeto de trabalho técnico social Condomínio de habitação de interesse social Colinas da Oeste. Mimeo, nov/2007. . Relatório socioeconômico - Condomínio de habitação de interesse social Colinas da Oeste. Mimeo, 2007.

. Relatório de acompanhamento do trabalho técnico social - Condomínio de habitação de interesse social Colinas da Oeste. Mimeo, julho/2008.

BRASIL. Ministério das Cidades. SNPU. Boletim relatório de avaliação - Programa Papel Passado. Brasília: Diretoria de Assuntos Fundiários, Secretaria Nacional de Programas Urbanos, Ministério das Cidades, mimeo, 2006.

BRASIL. Ministério das Cidades. Conselho das Cidades. Resolução recomendada no 11, de 08 de junho de 2006.

CEF. Circular CEF no10 de 12 de dezembro de 1991. mimeo, 1991.

CEF. Relatório de gestão - prestação de contas FDS - 2005. Brasília, 2005. 
CEF. Orientação Técnica, Programa Crédito Solidário. Brasília, março de 2006.

FNRU. Propostas do FNRU para o programa Crédito Solidário do Ministério das Cidades, (01/10/2004) Disponível em: www.forumreformaurbana.org.br

FNRU. Boletim Especial do FRNU- novembro de 2005: E o Programa Crédito Solidário, como fica?"(24/11/2005). Disponível em: www.forumreformaurbana.org.br

FRANCISCO, Neuza Alves .Parecer técnico social ao(sic) Programa Che Roga Mi mutirão convênio firmado com MNLM em Mato Grosso do Sul. Mato Grosso do Sul, Secretaria de Habitação e Infra-estrutura. Mimeo, s/d.

PARTIDO DOS TRABALHADORES. Diretório Nacional. As bases do Plano Alternativo de Governo - 1989. Brasil Urgente, Lula presidente. São Paulo: diretório nacional, 1989. Disponível em: www.fpabramo.org.br

PARTIDO DOS TRABALHADORES. Diretório Nacional. Diretrizes do Programa de Governo 1994. Frente Brasil popular pela cidadania. São Paulo: diretório nacional, 1994. Disponível em: www.fpabramo.org.br

PARTIDO DOS TRABALHADORES. Diretório Nacional. Diretrizes do Programa de Governo 1998. União do povo, muda Brasil. São Paulo: diretório nacional, 1998. Disponível em: www.fpabramo.org.br

PARTIDO DOS TRABALHADORES. Diretório Nacional. Diretrizes do Programa de Governo 2002. Coligação Lula presidente. São Paulo: diretório nacional, 2002. Disponível em: www.fpabramo.org.br

\section{Endereços eletrônicos consultados}

Agência Brasil - EBC: $\underline{\text { www.agenciabrasil.gov.br }}$

Associação Brasileira de Organizações Não Governamentais: $\underline{\text { www.abong.org.br }}$

Caixa Econômica Federal (CEF): $\underline{\text { www.caixa.gov.br }}$

Folha de São Paulo: www1.folha.uol.com.br/fsp/ 
Fórum Nacional da Reforma Urbana: $\underline{\text { www.forumreformaurbana.org.br }}$

Fundação Joaquim Nabuco: www.fundaj.gov.br

Fundação Perseu Abramo: www.fpabramo.org.br

Instituto Brasileiro de Geografia e Estatística: http://ibge.gov.br

Instituto Brasileiro de Direito Público: http://www.direitodoestado.com.br

Instituto de Pesquisa Econômica Aplicada (IPEA): www.ipea.gov.br

Ministério das Cidades: www.cidades.gov.br

Ministério do Trabalho: www.mte.gov.br

Observatório das Metrópoles/IPPUR: http://www.observatoriodasmetropoles.ufri.br

Prefeitura do Município de Recife: www.recife.pe.gov.br

Radio Brás: www.radiobras.gov.br

Revista Multiciência: http://www.multiciencia.unicamp.br

Secretaria de Estado de Habitação do Governo do MS: http://www.sehab.ms.gov.br

Secretaria de Estado de Desenvolvimento Urbano da BA: http://www.sedur.ba.gov.br

Secretaria de Habitação Salvador: www.sehab.salvador.ba.gov.br

União Nacional de Moradia Popular: www.unmp.org.br

União dos Movimentos de Moradia de São Paulo: http://www.sp.unmp.org.br/

União de Moradia Popular - Bahia: http://ba.unmp.org.br

\section{Legislação consultada}

BRASIL. LEI FEDERAL № 11888 DE 24 DE DEZEMBRO DE 2008

BRASIL. LEI FEDERAL № 11578 DE 26 DE NOVEMBRO DE 2007

BRASIL. LEI FEDERAL № 11481 DE 31 DE MAIO DE 2007

BRASIL. LEI FEDERAL № 11124 DE 16 DE JUNHO DE 2005

BRASIL. LEI FEERAL № 8677 DE 13 DE JULHO DE 1994

BRASIL. DECRETO FEDERAL № 1081 DE 08 DE MARÇO DE 1994 
BRASIL. PORTARIA - SPU №436 DE 28 DE NOVEMBRO DE 2008

BRASIL. MINISTÉRIO DAS CIDADES. INSTRUÇÃO NORMATIVA №14 DE 25/MARÇO/2008 BRASIL. MINISTÉRIO DAS CIDADES. INSTRUÇÃO NORMATIVA №04 DE 06/FEVEREIRO/2007 BRASIL. MINISTÉRIO DAS CIDADES. INSTRUÇÃO NORMATIVA №39 DE 28/DEZEMBRO/2005 BRASIL. MINISTÉRIO DAS CIDADES. INSTRUÇÃO NORMATIVA №38 DE 28/DEZEMBRO/2005 BRASIL. MINISTÉRIO DAS CIDADES. INSTRUÇÃO NORMATIVA №11, DE 14/MAIO/2004 BRASIL. CCFDS. RESOLUÇÃO. №123 DE 02/FEVEREIRO/2008 BRASIL. CCFDS. RESOLUÇÃO. №121 DE 09/JANEIRO/2008 BRASIL. CCFDS. RESOLUÇÃO. №120 DE 02/JANEIRO/2008 BRASIL. CCFDS. RESOLUÇÃO. №114 DE 19/JANEIRO/2007 BRASIL. CCFDS. RESOLUÇÃO. №106 DE 23/NOVEMBRO/2005 BRASIL. CCFDS. RESOLUÇÃO. №100 DE 16/FEVEREIRO/2005 BRASIL. CCFDS. RESOLUÇÃO. №94 DE 02/JUNHO/2004 BRASIL. CCFDS. RESOLUÇÃO. №93 DE 28/ABRIL/2004 BRASIL. CGFNHIS. RESOLUÇÃO. №47 DE 08/OUTUBRO/2008 MUNICÍPIO DE GOIÂNIA, LEI COMPLEMENTAR №171 DE 2007 - Plano Diretor de Goiânia MUNICÍPIO DE SALVADOR, LEI MUNICIPAL №7400 DE 2008 - Plano Diretor de Desenvolvimento Urbano de Salvador.

\section{Entrevistas realizadas}

Antônia de Pádua (Liderança da CMP - Belo Horizonte) - 27.02.2008

Bismarque Roberto Miranda (Liderança do MNLM - Tocantins) - 01.04.2008

César Ramos (Coordenador do PCS/ Ministério das Cidades) - 13.02.2008

Cláudia Gomes (GESEF/ CEF - Brasília) - 24.03.2008

Dona Maria José Alves - D. Bézinha (Liderança do MNLM - Paraíba) - 01.04.2008

Ênio Nonato de Oliveira (Liderança da CONAM - Minas Gerais) - 01.04.2008 
Evaniza Rodrigues (Liderança da UNMP - São Paulo) - 27.02.2008

Henriqueta Alves (CBIC e Assessora da FAMENG - Minas Gerais) - 02.04.2008

Isabel Cabral e Ricardo Gaboni (Ambiente - São Paulo) - 10.03.2008

Leonardo Pessina (Assessoria Técnica CAAP - Santa Catarina) - 19.03.2008

Luciana Royer (Arquiteta da GIDUR/ CEF - São Paulo) - 25.01.2008

Modesto Azevedo (Liderança do UNMP - Santa Catarina) - 02.04.2008 


\section{Anexos (CD)}

\section{Entrevistas}

1. Luciana Royer (Arquiteta da GIDUR/ CEF - São Paulo) - 25.01.2008

2. César Ramos (Coordenador do PCS/ Ministério das Cidades) - 13.02.2008

3. Antônia de Pádua (Liderança da CMP - Belo Horizonte) - 27.02.2008

4. Evaniza Rodrigues (Liderança da UNMP - São Paulo) - 27.02.2008

5. Isabel Cabral e Ricardo Gaboni (Ambiente - São Paulo) - 10.03.2008

6. Leonardo Pessina (Assessoria Técnica CAAP - Santa Catarina) - 19.03.2008

7. Cláudia Gomes (GESEF/ CEF - Brasília) - 24.03.2008

8. Bismarque Roberto Miranda (Liderança do MNLM - Tocantins) - 01.04.2008

9. Dona Maria José Alves - D. Bézinha (Liderança do MNLM - Paraíba) - 01.04.2008

10. Ênio Nonato de Oliveira (Liderança da CONAM - Minas Gerais) - 01.04.2008

11. Henriqueta Alves (CBIC e Assessora da FAMENG - Minas Gerais) - 02.04.2008

12. Modesto Azevedo (Liderança do UNMP - Santa Catarina) - 02.04.2008

\section{Documentos oficiais referentes ao Programa Crédito Solidário}

1. Documentos oficiais da CAIXA

2. Resoluções do CCFDS

3. Instruções Normativas do Ministério das Cidades

\section{Legislação}

1. BRASIL. LEI FEDERAL № 11888 DE 24 DE DEZEMBRO DE 2008

2. BRASIL. LEI FEDERAL № 11578 DE 26 DE NOVEMBRO DE 2007

3. BRASIL. LEI FEDERAL № 11481 DE 31 DE MAIO DE 2007

4. BRASIL. LEI FEDERAL № 11124 DE 16 DE JUNHO DE 2005

5. BRASIL. LEI FEERAL № 8677 DE 13 DE JULHO DE 1994

6. BRASIL. DECRETO FEDERAL № 1081 DE 08 DE MARÇO DE 1994 


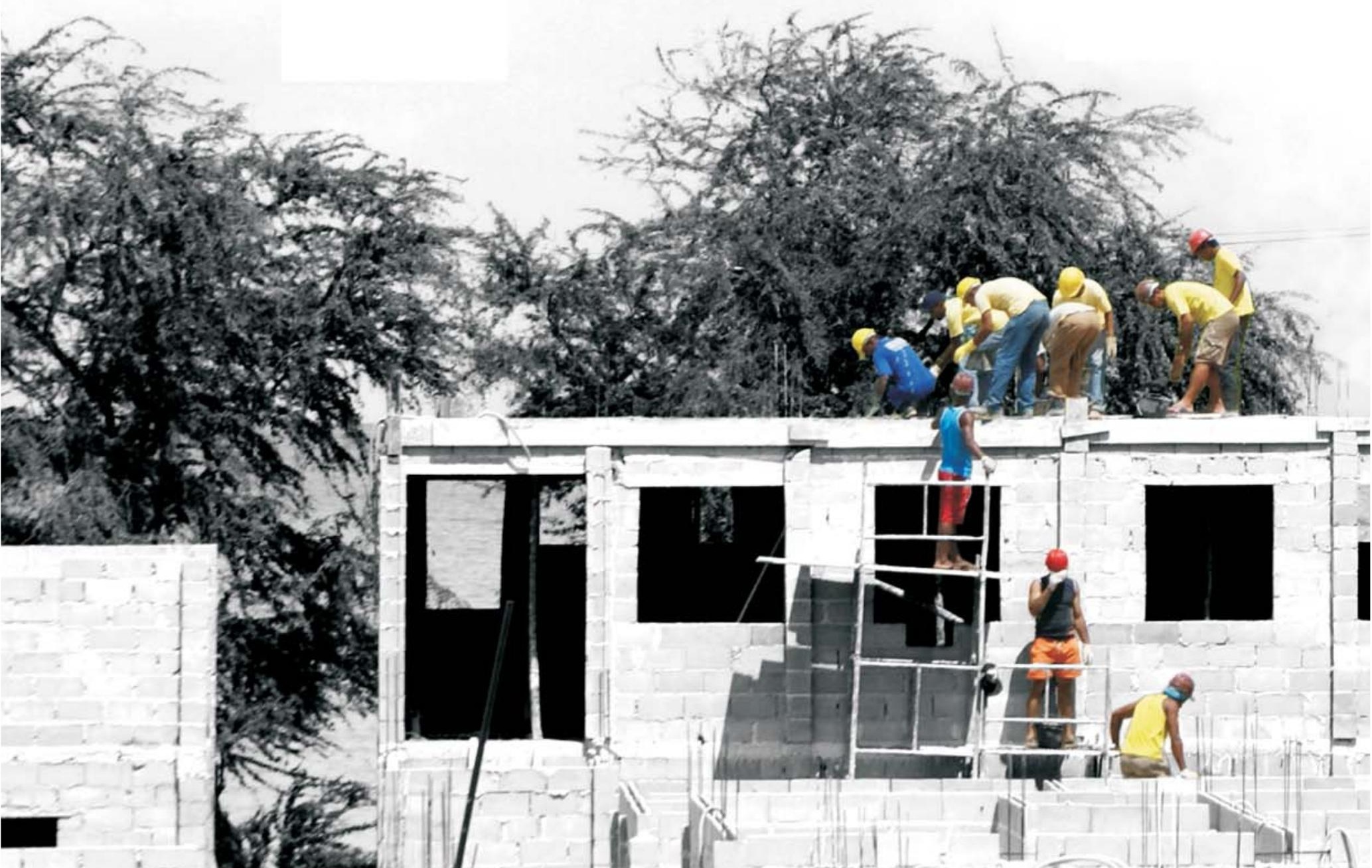

